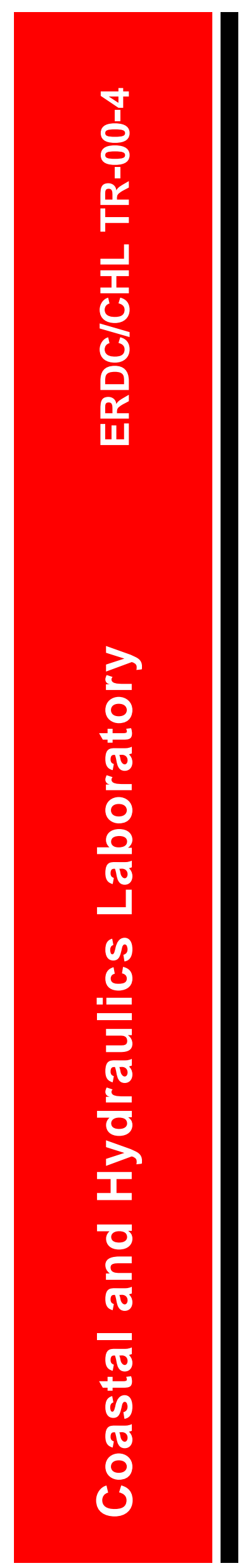

\title{
Salinity Intrusion in the Panama Canal
}

T. M. Parchure, Steven C. Wilhelms, Soraya Sarruff, and William H. McAnally

April 2000

US Army Corps of Engineers $\odot$

Engineer Research and Development Center 
The contents of this report are not to be used for advertising, publication, or promotional purposes. Citation of trade names does not constitute an official endorsement or approval of the use of such commercial products.

The findings of this report are not to be construed as an official Department of the Army position, unless so designated by other authorized documents. 


\section{Salinity Intrusion in the Panama Canal}

by T. M. Parchure, Steven C. Wilhelms, Soraya Sarruff, William H. McAnally

Coastal and Hydraulics Laboratory

U.S. Army Engineer Research and Development Center

3909 Halls Ferry Road

Vicksburg, MS 39180-6199

Final report

Approved for public release; distribution is unlimited

Prepared for U.S. Army Engineer District, Mobile

Mobile, AL 36602

Canal Capacity Projects Office

Panama Canal Commission

Panama 


\section{U.S. Army Engineer Research and Development Center Cataloging-in-Publication Data}

Salinity intrusion in the Panama Canal / by T.M. Parchure ... [et al.] ; prepared for U.S. Army Engineer District, Mobile, Canal Capacity Projects Office, Panama Canal Commission.

231 p. : ill. ; $28 \mathrm{~cm}$.-- (ERDC/CHL ; TR-00-4)

Includes bibliographic references.

1. Saltwater encroachment -- Panama -- Panama Canal. 2. Saline water barriers -- Panama

-- Panama Canal. 3. Saline waters -- Panama -- Panama Canal. 4. Panama Canal

(Panama) I. Parchure, T. M. (Trimbak Mukund), 1943- II. United States. Army. Corps of

Engineers. Mobile District. III. Engineer Research and Development Center (U.S.)

IV. Coastal and Hydraulics Laboratory (U.S.) V. United States. Panama Canal Commission.

Canal Capacity Projects Office. VI. Series: ERDC/CHL TR ; 00-4.

TA7 E8 no.ERDC/CHL TR-00-4 


\section{Contents}

Preface .viii

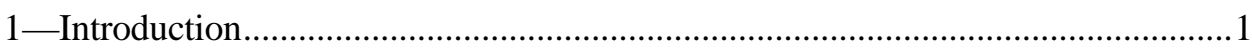

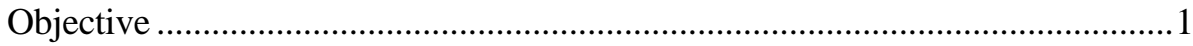

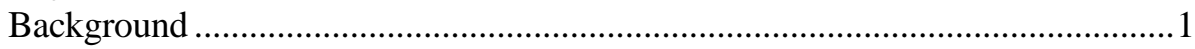

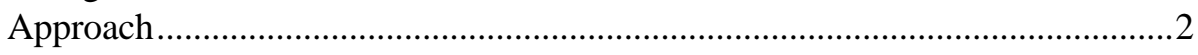

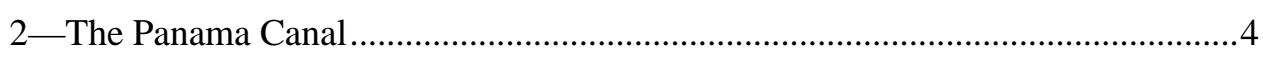

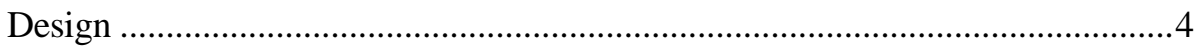

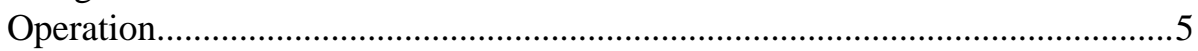

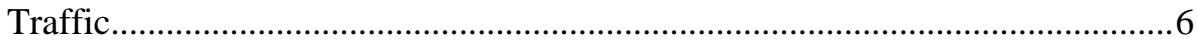

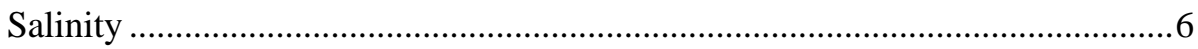

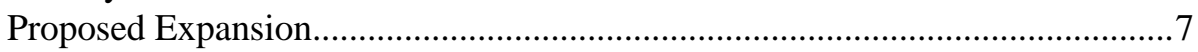

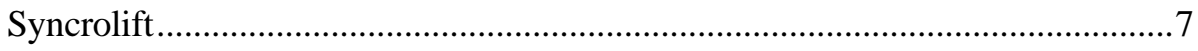

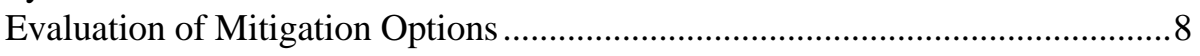

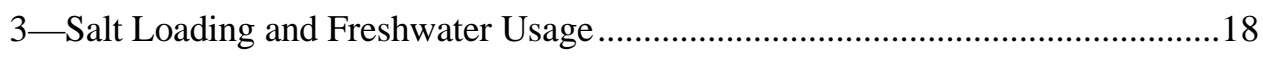

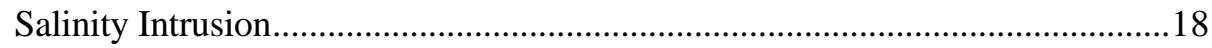

Calculating Salinity and Exchanges in the Locks..............................................19

Zero-Dimensional Model of Gatun Lake Salinity .............................................26

Recirculation of Lift Water in Holding Ponds...................................................28

4-Methods of Reducing Saltwater Intrusion in Navigation Locks .........................38

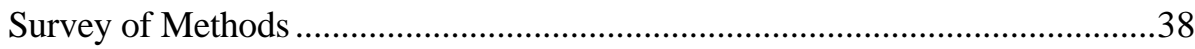

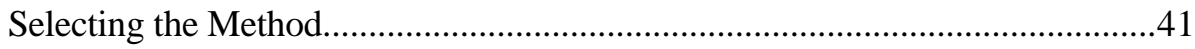

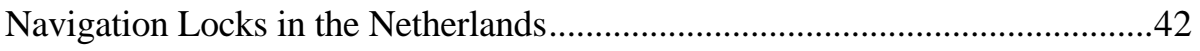

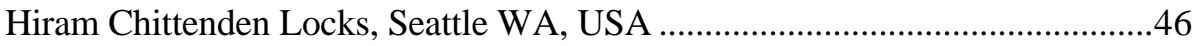

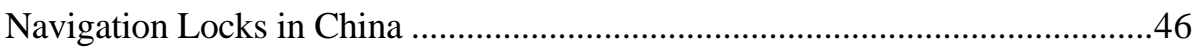

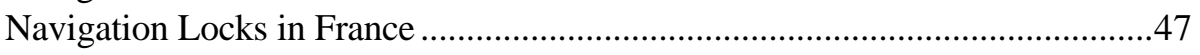

Salinity Intrusion Problems in Norway..........................................................47 
Syncrolift Lock

Summary and Conclusions...........................................................................48

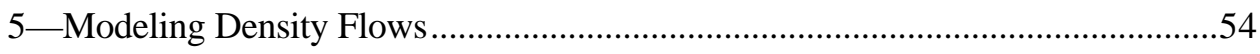

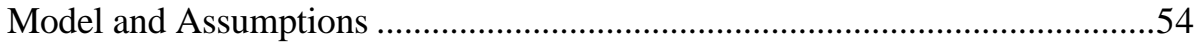

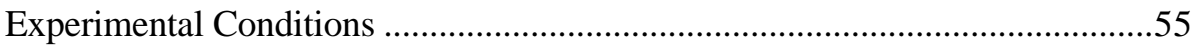

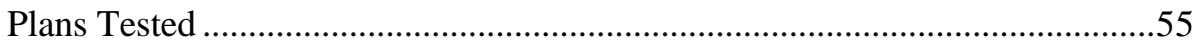

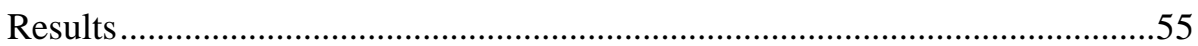

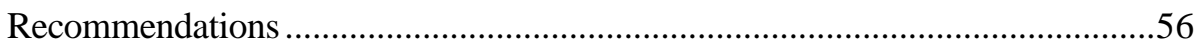

6-Modeling Salt Movement Across Gatun Lake ....................................................68

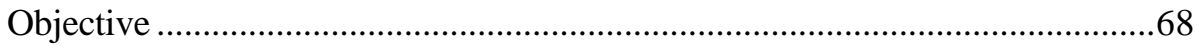

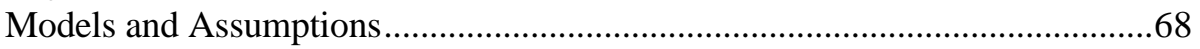

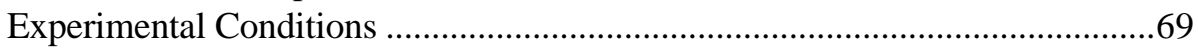

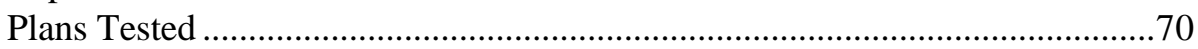

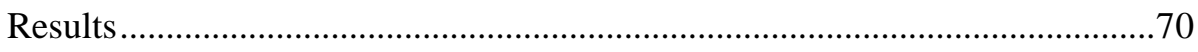

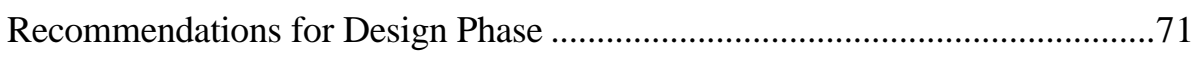

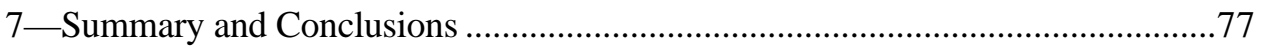

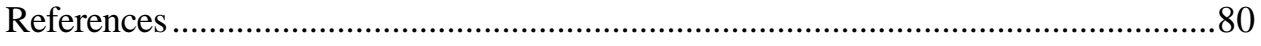

Appendix A: Salt Loading Example Calculations ..................................................A1

Appendix B: Summary of Saltwater Intrusion Problems at

Inland Navigation Channels in the United States............................................ B1

Appendix C: Salinity Intrusion at Lake Washington Locks and

Ship Canal Project Seattle, WA, USA..............................................................

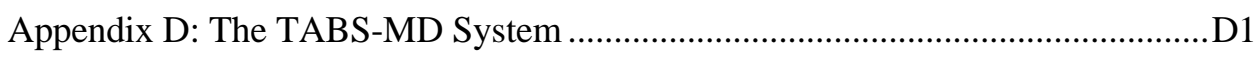

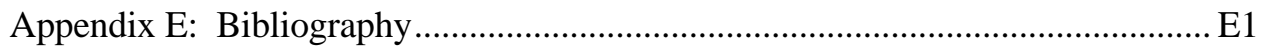

SF 298

\section{List of Figures}

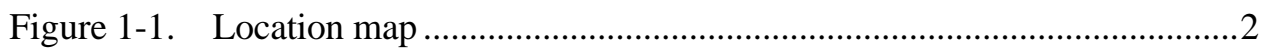

Figure 1-2. Panama Canal index map ……….................................................. 3

Figure 2-1. Existing locks layout and dimensions ..............................................

Figure 2-2. Panama-size vessel and required lock dimensions .............................10 


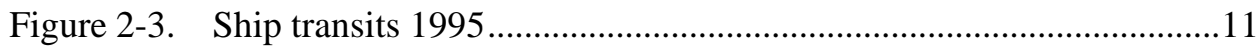

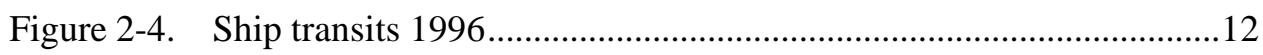

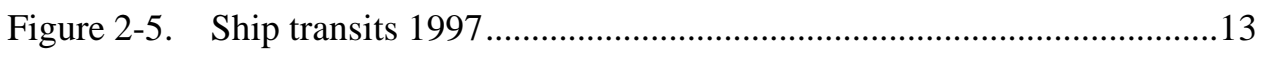

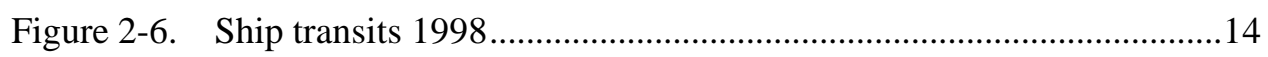

Figure 2-7. Artist's impression of a Syncrolift lock ............................................15

Figure 2-8. Schematic of Syncrolift Lock with flushing ......................................16

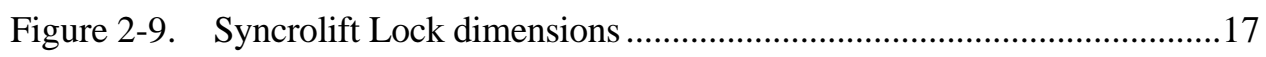

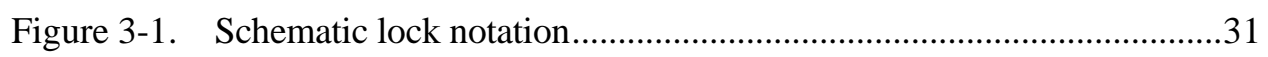

Figure 3-2. Case 1: Gatun Lake Salinity, 38 locks/day on conventional locks, no lockages/day on Syncrolift Locks, lock exchange ratio of 50 percent, salinity of $0.100 \mathrm{ppt}$ in conventional locks and 0.0 ppt in Syncrolift Lock ...................................................32

Figure 3-3. Case 2: Gatun Lake Salinity, 38 locks/day on conventional locks, 20 lockages/day on Syncrolift Locks, lock exchange ratio of 50 percent, salinity of $0.100 \mathrm{ppt}$ in conventional locks and $35.0 \mathrm{ppt}$ in Syncrolift Lock

Figure 3-4. Case 3: Gatun Lake Salinity, 38 locks/day on conventional locks, 20 lockages/day on Syncrolift Locks, lock exchange ratio of 50 percent, salinity of $0.100 \mathrm{ppt}$ in conventional locks and $4.5 \mathrm{ppt}$ in Syncrolift Lock .33

Figure 3-5. Case 4: Gatun Lake Salinity, 38 locks/day on conventional locks, 20 lockages/day on Syncrolift Locks, lock exchange ratio of 50 percent, salinity of $0.100 \mathrm{ppt}$ in conventional locks and 0.300 ppt in Syncrolift Lock.....

Figure 3-6. Schematic of recirculating lift water through holding ponds and pumping

Figure 3-7. Gatun Locks salinities and freshwater consumption with holding pond recirculation for Case 1: ponds holding two lift volumes with initial salinity of $0 \mathrm{ppt} ; 100$ percent of lift volume from holding pond

Figure 3-8. Miraflores Locks salinities and freshwater consumption with holding pond recirculation for Case 1: ponds holding two lift volumes with initial salinity of $0 \mathrm{ppt} ; 100$ percent of lift volume from holding pond..... 
Figure 3-9. Gatun Locks salinities and freshwater consumption with holding pond recirculation for Case $\mathrm{P} 4$ : ponds holding two lift volumes with initial salinity of $0 \mathrm{ppt} ; 100$ percent of lift volume from holding pond, and limiting salinity of $0.3 \mathrm{ppt}$. 37

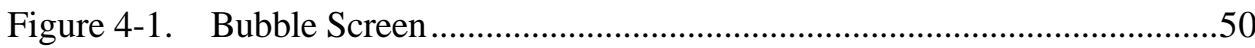

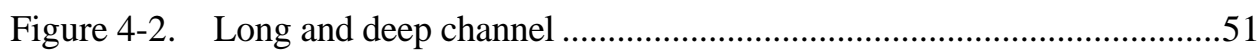

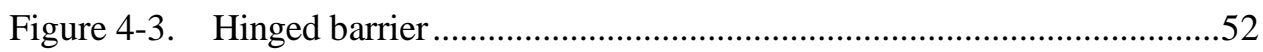

Figure 4-4. Schematical syncrolift lock with gated salt water extraction chamber.

Figure 5-1. Details: Segment distribution for Gatun Lake computational grids

Figure 5-2. Segment distribution for Lake Gatun computational grids .65

Figure 5-3. Width contours 10-m-deep channel sump .66

Figure 5-4. Longitudinal Profile of width used in salinity trap and extraction calculations

Figure 6-1. Depth-integrated model computational mesh of Gatun Lake and Panama Canal. Shaded areas indicate bottom elevation of lake in feet .72

Figure 6-2. Salinity profiles at Pedro Miguel Locks and surrounding areas for dry and wet seasons

Figure 6-3. Salinity patterns near Gatun Locks for dry and wet seasons

Figure 6-4. Concentration patterns for the Syncrolift lock plan in dry and wet seasons

Figure 6-5. Concentration patterns at Gatun Locks for dry and wet seasons with both existing locks and Syncrolift in operation

Figure A1. Schematic plan and elevations for Panama Canal Locks A17

Figure $\mathrm{C} 1$. Photograph and project layout . 9

Figure C2. General project features $\mathrm{C} 10$

Figure C3. Field data collected in May 99 at the upstream nose pier of large Chittenden Lock. 
Figure D1. TABS-MD schematic ……….......................................................... 2

Figure D2. Two-dimensional finite element mesh................................................ D4

\section{List of Tables}

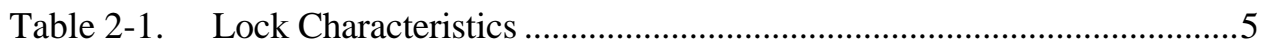

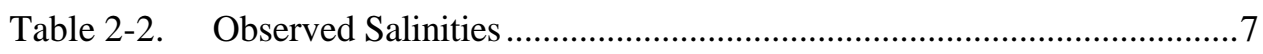

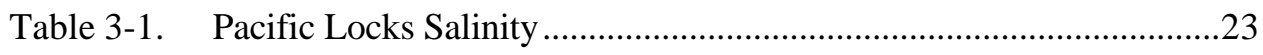

Table 3-2. Atlantic Locks Salinity ..................................................................24

Table 3-3. Estimates of Salinities Resulting from Ships Transiting

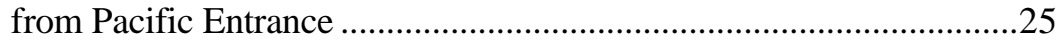

Table 3-4. Estimate of Salt Transfer Coefficients from Atlantic Entrance ...........25

Table 3-5. Data Used in Zero-Order Model Analysis ........................................27

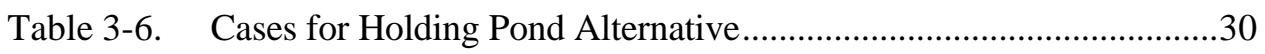

Table 5-1. Gatun Lake Zero-Order Salinity Intrusion Model v1.1,

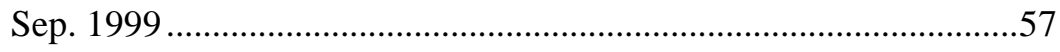

Table 5-2. Zero-Order Miraflores Lake Salinity Model v1.0, Aug. 1999............61

Table A1. Physical Characteristics at Panama Canal Locks...............................A2

Table A2. Salinity Values Derived from Field Observations .............................A2

Table A3. Assumptions Made in Salt Loading Computations ...........................A3

Table A4. Notations Used in Salinity Computations .......................................A3

Table A5. Estimates of Salinities Resulting from Ships Transiting from

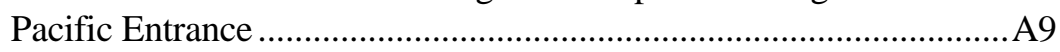

Table A6. Estimate of Transfer Coefficients for Salt Loading from Pacific Entrance

Table A7. Sensitivity Analysis Illustrating Impact of Miraflores Lake Salinity Magnitude. 
Table A8. Notations Used in Salinity Computations

Table A9. Estimate of Salinities Resulting from Ships Transiting from Atlantic Entrance.

Table A10. Estimate of Salt Transfer Coefficients from Atlantic Entrance........A16 


\section{Preface}

The work described here was conducted at the Coastal and Hydraulics Laboratory (CHL) of the U. S. Army Engineer Research and Development Center (ERDC), Vicksburg, MS, during 1999. Funding was provided by the Canal Capacity Projects Office, Panama Canal Commission (PCC) through the U.S. Army Engineer District, Mobile under Memorandum of Agreement ISSA 97-003, Work Order 23. Mr. Billy Brown of the Mobile District served as U.S. Army Corps of Engineers program manager. Messrs. John Gribar and Rigoberto Delgado served as the PCC primary points of contact.

Dr. Trimbak M. Parchure, CHL, was the principal investigator for the described work. Dr. Parchure conducted the work under general supervision of Dr. Robert T. McAdory, Chief, Tidal Hydraulics Branch, Dr. William H. McAnally, Chief, Estuaries and Hydrosciences Division, and Dr. James R. Houston, Director, Coastal and Hydraulics Laboratory. Other contributors to the work were Dr. Steven C. Wilhelms, Ms. Soraya Saruff, and Dr. McAnally of CHL, Mr. Delgado, PCC, Mr. Cesar Kiamco, PCC, and Mr. A. David Schuldt, USAE District, Seattle (retired) who wrote Appendix C.

The report is published by the Coastal and Hydraulics Laboratory. The CHL was formed in October 1996 with the merger of the Waterways Experiment Station (WES) Coastal Engineering Research Center and Hydraulics Laboratory. WES has now become part of ERDC. Dr. James R. Houston is the Director of CHL.

During the preparation and publication of this report, Dr. Lewis E. Link was Acting Director of ERDC and Col. Robin Cababa, EN, was Commander. 


\section{Conversion Factors, Non-SI to SI Units of Measurement}

\begin{tabular}{||l|l|l||}
\hline Multiply & \multicolumn{1}{l|}{ By } & To Obtain \\
\hline \hline acres & $4,046.873$ & square meters \\
\hline cubic feet & 0.02831685 & cubic meters \\
\hline cubic feet per sec (cfs) & 0.028317 & cu meters per sec \\
\hline cubic yards & 0.7645549 & cubic meters \\
\hline degrees Fahrenheit & $5 / 9$ & degrees Celsius or kelvins \\
\hline fathoms & 1.8288 & meters \\
\hline feet & 0.3048 & meters \\
\hline gallons (U.S. liquid) & 0.003785412 & cubic meters \\
\hline inches & 0.0254 & meters \\
\hline miles (U.S. statute) & 1.609347 & kilometers \\
\hline pounds (mass) & 0.4535924 & kilograms \\
\hline square feet & 0.09290304 & square meters \\
\hline square miles & 2.59 & kilometers \\
\hline square yards & 0.8361274 & square meters \\
\hline tons (2240 pounds mass) & 1.01605 & metric tons \\
\hline tons (2240 pounds mass) & 1016.05 & kilograms \\
\hline yards & 0.9144 & meters \\
\hline
\end{tabular}




\section{Introduction}

\section{Objective}

This report documents the results of salinity intrusion analyses for the Panama Canal, Panama. The objective of these analyses is to provide an early estimate of changes in salinity intrusion and freshwater usage that may result from an expansion of canal locks capacity, and to identify measures that may reduce salinity intrusion and freshwater consumption if unacceptable increases are forecast.

\section{Background}

The Panama Canal is an 80-kilometer (50-mile) long, man-made waterway connecting the Atlantic Ocean (Caribbean Sea) and Pacific Ocean (Bay of Panama) for purposes of navigation (Figure 1-1). It became operational on August 15, 1914. Ship traffic through the canal has steadily increased in terms of size and frequency and currently about thirty-eight ships transit the canal each day. The canal between the two oceans passes through two natural fresh water lakes-Gatun Lake and Miraflores Lake (see Figure 1-2).

Fresh water from Gatun and Miraflores lakes is used for filling the navigation locks while transiting ships in and out of the lakes. Salt water from the ocean gets added to the lakes by density currents and fresh water from the lakes is lost to the sea during transit of ships. The net loss of fresh water is estimated by the Panama Canal Commission to be about fifty-two million gallons per lockage operation. Fresh water is also supplied to the local population in two cities for drinking purposes at the rate of about forty-seven million gallons per day. During years of low rainfall, a shortage of fresh water is experienced for canal operations.

The Panama Canal Commission is considering expanding the existing ship transit capacity of the canal, which may further increase freshwater consumption and increase salt intrusion from the ocean. The Commission needs an estimate of the potential adverse effects of capapacity expansion and an early indication if remedial measures can be expected to provide protection from those impacts. 


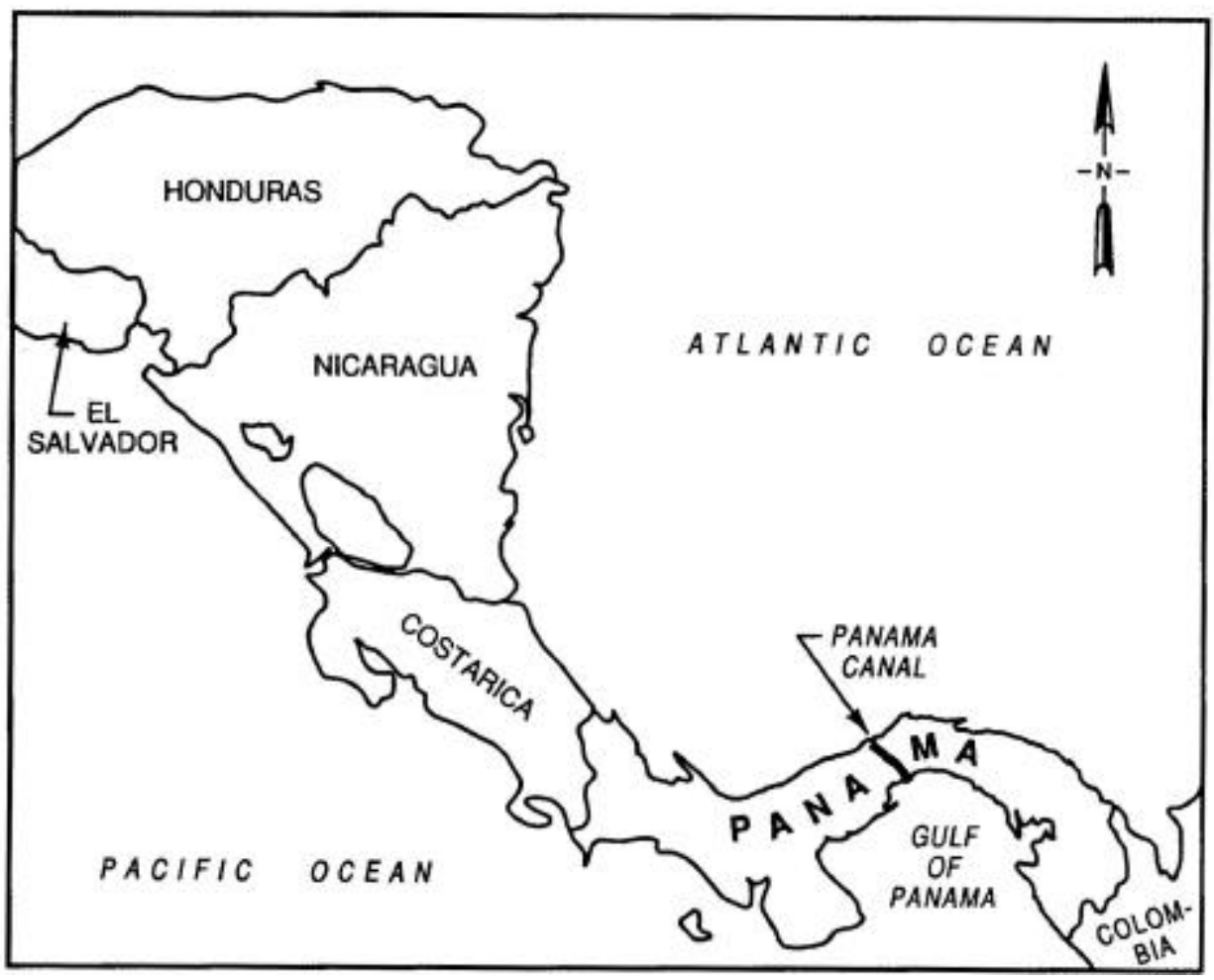

Figure 1-1. Location map

\section{Approach}

The objectives were achieved by combining desktop reviews and analytic tools with simple, unverified numerical models that provided rapid estimates of salinity intrusion through the locks and freshwater usage. The following tasks were performed: data on ship transits and observed salinities assembled by Panama Canal Commission staff were compiled and analyzed; a literature review identified potential salinity mitigation methods; spreadsheet calculations characterized salt loading and water usage; a two-dimensional width-averaged (2DV) numerical model was run to define density-driven flow out of the upper locks; and a two-dimensional depth-averaged $(2 \mathrm{DH})$ numerical model was run to depict the dispersion path of salt water if it were released into Gatun Lake. The numerical models were applied without verifying them to field observations, an approach which is satisfactory for demonstrating feasibility of plans. If a canal capacity expansion plan is selected for design, these models should be verified to field data before testing the design plan.

Three conditions - existing conditions, use of holding ponds to recirculate lock lift water and conserve fresh water, and use of a Syncrolift lock (see Part 2) to increase transit capacity - were examined, and a number of salinity intrusion mitigation measures were examined for feasibility. Model results for two mitigation methods are presented here - a salt water sump and a gated transition chamber. 


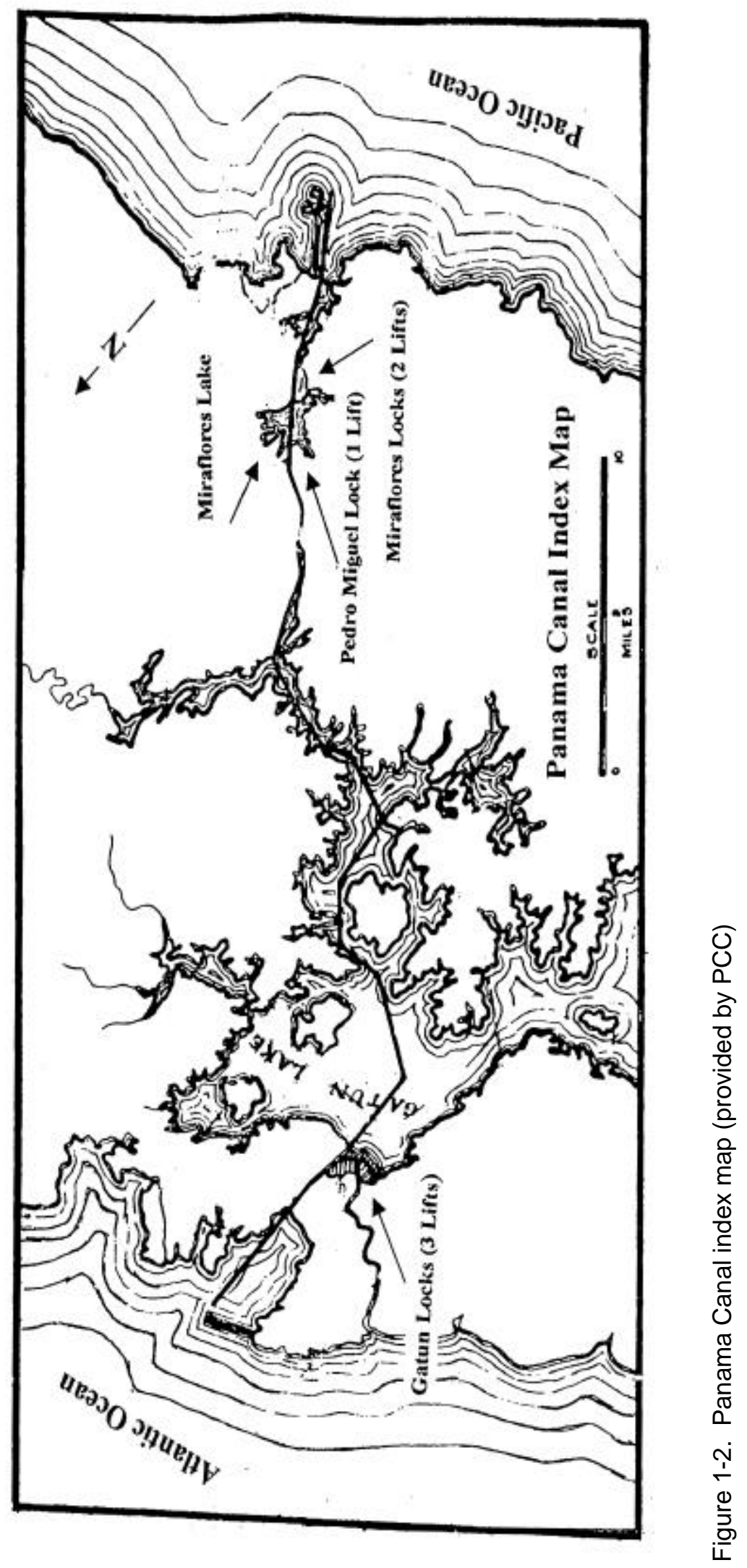




\section{The Panama Canal}

\section{Design}

The $80 \mathrm{~km}$ (50 mile) long man-made Panama Canal connects the Atlantic Ocean on the North side and the Pacific Ocean on the South side (Figure 1-2). On its way it passes through Gatun Lake and Miraflores Lake, in which controlled water levels are maintained at $26 \mathrm{~m}$ ( 85 feet) and $16.5 \mathrm{~m}$ (54 feet) above mean sea level, respectively. During high rainfall season Gatun Lake is maintained at a level of $26.7 \mathrm{~m}$ (87.5 feet).

Both the Gatun Lake and Miraflores Lake are fresh water lakes. Gatun Lake has an estimated storage of 5.2 billion cubic $\mathrm{m}$ (183 billion cubic feet) at a lake level of $26 \mathrm{~m}$ ( $85 \mathrm{feet}$ ) and 5.56 billion cu ft (196 billion cubic feet) at an elevation of $26.7 \mathrm{~m}$ ( 87.5 feet). It has a surface area of $435 \mathrm{sq} \mathrm{km}$ (168 square miles) at an elevation of $26.7 \mathrm{~m}$ ( 87.5 feet). Gatun Lake was created by placing an earthen dam across the Chagres River. The Gatun Dam is nearly $2.4 \mathrm{~km}$ (1.5 mile) long and $0.8 \mathrm{~km}$ (half mile) wide at the base, sloping to a width of $30.48 \mathrm{~m}$ (100 feet) at the crest, which is $32 \mathrm{~m}$ (105 feet) above the sea level, or $6 \mathrm{~m}$ (20 feet) above the normal level of Gatun Lake. Another series of dams was constructed under the Madden Dam Project, which stores rain water from the catchment area of about $3367 \mathrm{sq} \mathrm{km} \mathrm{(1300} \mathrm{sq} \mathrm{miles).} \mathrm{The} \mathrm{main} \mathrm{features} \mathrm{include}$ the main concrete dam, a hydro power station and several earth and gravel-fill dams. Water level in the Gatun Lake is regulated by releasing excess water to the sea over the spillway of Gatun Dam and by letting in water from the Madden Dam. Water level in Miraflores Lake is regulated through the Miraflores Dam, which is a gravity concrete dam. The dam has a spillway with a design capacity of $2832 \mathrm{cu} \mathrm{m} / \mathrm{s}(100,000 \mathrm{cfs})$ at the highest allowable level. Miraflores Lake is much smaller compared to the Gatun Lake. It has a surface area of $3.94 \mathrm{sq} \mathrm{km}$ (1.52 sq miles) at an elevation of $16.5 \mathrm{~m}$ (54 feet). Available active storage of Miraflores Lake between elevations $16 \mathrm{~m}$ and $17 \mathrm{~m}$ (53 and $55 \mathrm{feet}$ ) is approximately 2.5 million cu $\mathrm{m}$ ( 88 million cu feet) and the total storage is on the order of 19 million cu m (670 million cubic feet).

Fresh water from these two lakes is used for filling the navigation locks while transiting ships through the canal. Salt water from the ocean gets added to the lakes during transit of ships from the ocean to the lakes, and fresh water from the lakes is lost to the sea while transiting ships from the lakes to the sea. The net loss of fresh water is estimated to be about 0.20 million cu m (52 million 
gallons) per lockage operation. Fresh water from Gatun Lake is also supplied to the local population in two cities for drinking purposes at the rate of about 0.18 million cu m (47 million gallons) per day. During years of low rainfall, a shortage of fresh water is experienced for canal operations.

The Panama Canal has six twin locks, grouped in three sets, namely Miraflores Locks (2 lifts) and Pedro Miguel Lock (1 lift) on the Pacific side and Gatun Locks (3 lifts) on the Atlantic side (Figure 2-1). The three navigation locks on each end lift ships from the ocean to the Gatun Lake through a height of $26 \mathrm{~m}$ ( 85 feet) above sea level and then lower them through three locks, bringing them back to the ocean level. The channel that connects Gatun Lake to the Miraflores Lake is called Gaillard Cut. Ships travel for about $37 \mathrm{~km}$ (23 miles) from Gatun Locks to the north end of Gaillard Cut. The twin locks serve two purposes; one as a stand-by in case of closure of one system of locks and the second to serve as an alternate system of locks for transiting multiple small ships in a single transit.

Physical characteristics of the six locks are given in Table 2-1 below.

\begin{tabular}{|c|c|c|c|c|}
\hline \multicolumn{5}{|c|}{$\begin{array}{l}\text { Table } 2-1 \\
\text { Lock Characteristics }\end{array}$} \\
\hline Lock & $\begin{array}{l}\text { Width \& Length } \\
(\mathrm{ft}) /(\mathrm{m})\end{array}$ & $\begin{array}{l}\text { Lift Height } \\
(\mathrm{ft}) /(\mathrm{m})\end{array}$ & $\begin{array}{l}\text { Lift Volume } \\
\text { (cft)/(cu m) }\end{array}$ & $\begin{array}{l}\text { Bed Level } \\
(\mathrm{ft}) /(\mathrm{m})\end{array}$ \\
\hline $\begin{array}{l}\text { Lower Miraflores } \\
\text { Lock }\end{array}$ & $\begin{array}{l}110 \times 1051 \mathrm{ft} \\
33.5 \times 320.3 \mathrm{~m}\end{array}$ & $\begin{array}{l}26 \mathrm{ft} \\
7.9 \mathrm{~m}\end{array}$ & $\begin{array}{l}3.005 \times 10^{6} \\
0.851 \times 10^{5}\end{array}$ & $\begin{array}{l}-52 \mathrm{ft} \\
-16 \mathrm{~m}\end{array}$ \\
\hline $\begin{array}{l}\text { Upper Miraflores } \\
\text { Lock }\end{array}$ & $\begin{array}{l}110 \times 1071 \mathrm{ft} \\
33.5 \times 326.4 \mathrm{~m}\end{array}$ & $\begin{array}{l}28 \mathrm{ft} \\
8.5 \mathrm{~m}\end{array}$ & $\begin{array}{l}3.298 \times 10^{6} \\
0.934 \times 10^{5}\end{array}$ & $\begin{array}{l}-20.3 \mathrm{ft} \\
-\quad 6.2 \mathrm{~m}\end{array}$ \\
\hline $\begin{array}{l}\text { Pedro Miguel } \\
\text { Lock }\end{array}$ & $\begin{array}{l}110 \times 1071 \mathrm{ft} \\
33.5 \times 326.4 \mathrm{~m}\end{array}$ & $\begin{array}{l}31 \mathrm{ft} \\
9.5 \mathrm{~m}\end{array}$ & $\begin{array}{l}3.652 \times 10^{6} \\
1.034 \times 10^{5}\end{array}$ & $\begin{array}{l}+11.0 \mathrm{ft} \\
+\quad 3.4 \mathrm{~m}\end{array}$ \\
\hline Upper Gatun Lock & $\begin{array}{l}110 \times 1071 \mathrm{ft} \\
33.5 \times 326.4 \mathrm{~m}\end{array}$ & $\begin{array}{l}28 \mathrm{ft} \\
8.5 \mathrm{~m}\end{array}$ & $\begin{array}{l}3.298 \times 10^{6} \\
0.934 \times 10^{5}\end{array}$ & $\begin{array}{l}+13.0 \mathrm{ft} \\
+\quad 3.9 \mathrm{~m}\end{array}$ \\
\hline $\begin{array}{l}\text { Middle Gatun } \\
\text { Lock }\end{array}$ & $\begin{array}{l}110 \times 1051 \mathrm{ft} \\
33.5 \times 320.3 \mathrm{~m}\end{array}$ & $\begin{array}{l}29 \mathrm{ft} \\
8.8 \mathrm{~m}\end{array}$ & $\begin{array}{l}3.352 \times 10^{6} \\
0.949 \times 10^{5}\end{array}$ & $\begin{array}{l}-15.3 \mathrm{ft} \\
-4.7 \mathrm{~m}\end{array}$ \\
\hline Lower Gatun Lock & $\begin{array}{l}110 \times 1051 \mathrm{ft} \\
33.5 \times 320.3 \mathrm{~m}\end{array}$ & $\begin{array}{l}28 \mathrm{ft} \\
8.5 \mathrm{~m}\end{array}$ & $\begin{array}{l}3.237 \times 10^{6} \\
0.917 \times 10^{5}\end{array}$ & $\begin{array}{l}-44.3 \mathrm{ft} \\
-13.5 \mathrm{~m}\end{array}$ \\
\hline
\end{tabular}

Balboa Port is located on the Pacific Ocean side and the Port of Cristobal is located on the Atlantic side. Two breakwaters are constructed on the Atlantic side to form Limon Bay, which provides shelter for ships against waves.

\section{Operation}

The canal operation consists of two distinct parts, namely raising a ship and lowering a ship. Water from Gatun Lake is released into the higher Gatun Lock and in the Pedro Miiguel Lock for lifting ships in these locks. Water from Miraflores Lake is released into upper Miraflores lock and from there to the lower Miraflores lock for lifting ship from a lower elevation. Large culverts are provided for filling and emptying the locks. A safe rate of change in water elevation in a lock is dependent on the distribution of water. For the Panama 
Canal locks a maximum rate of $2.3 \mathrm{~m}(7.5 \mathrm{ft})$ per minute with a good water distribution is considered optimum. It takes about 10 minutes to fill or empty a lock.

A ship has to transit through six locks and also sail through an $80.5 \mathrm{~km}$ (50-mile) long navigation channel. It requires about nine hours for an average ship to transit the canal. Larger ships are transited during daylight hours whereas smaller vessels are transited at any convenient time. Hydraulics of the Panama Canal Locks is described in detail in a paper by Whitehead (1915).

\section{Traffic}

Although 85 years old, the strategically located canal is still one of the most highly traveled waterways of the world. It operates 24 hours a day, 365 days a year transiting vessels of all nations. Since the opening of the waterway to world commerce, the canal has provided transit service to more than 700,000 vessels. Toll collection, which has reached about 500 million dollars a year, is a major source of income for the Republic of Panama. The physical dimensions of locks place a restriction on the maximum size of ship that can transit through the canal. This size, popularly known as the Panamax ship, is shown in Figure 2-2. The maximum length, width and draft for the Panamax ship are $294 \mathrm{~m}(965 \mathrm{ft})$, $33.5 \mathrm{~m}(110 \mathrm{ft})$ and $12 \mathrm{~m}(39.5 \mathrm{ft})$ respectively.

The number of ships that transited through the canal during 1995 through 1998 is shown in Figures 2-3 through 2-6.

\section{Salinity}

Very meager data are available on the salinity of water in the two lakes and inside and outside locks. Historical data on salinity are not available probably because in the past years an increase in salinity of lake water was neither noticed nor threatened under normal canal operation. Only during the recent years concern over possible increase in lake salinity was perceived due to increase in ship transits per day and low fresh water inflows. It is learned from verbal communication from PCC officials that the salinity of Miraflores Lake increased quickly immediately after commissioning of the canal, which lead to changing the location of intake for supply of fresh water to the city. Salt accumulation was noticed on the pipes of the power station. A steady-state salinity was however reached shortly (maybe within the first year or so) and the salinity of Miraflores Lake has been less than one part per thousand ever since. Salinity of Gatun Lake is known to be close to or equal to zero. It is reasonable to assume that the salt intake per ship transit is balanced by salt output from both the lakes resulting from the freshwater released per transit from the Gatun Lake.

Field data on salinity collected by PCC are summarized in Table 2-2 below. 


\begin{tabular}{|c|c|}
\hline $\begin{array}{l}\text { Table } 2-2 \\
\text { Observed Salinities }\end{array}$ & \\
\hline Location and Time & Observed Salinity (ppt) \\
\hline $\begin{array}{l}\text { Pacific Ocean just outside L1 } \\
\text { All times. }\end{array}$ & 10.0 \\
\hline $\begin{array}{l}\text { Inside L1 } \\
\text { Before lift. }\end{array}$ & 8.0 \\
\hline $\begin{array}{l}\text { Inside } L 2 \\
\text { After moving ship from } L 1 \text { to } L 2\end{array}$ & 1.5 \\
\hline $\begin{array}{l}\text { Miraflores Lake } \\
\text { All times }\end{array}$ & 1.0 \\
\hline
\end{tabular}

\section{Proposed Expansion}

The present system has reached its maximum capacity and there is no scope for increasing the number of ships transiting the canal per day. In order to increase transits, the Panama Canal Commission is considering various alternatives. Construction of an additional system of locks is a very expensive option. Providing a Syncrolift type of locks at both ends of the canal is being considered. See description below.

\section{Syncrolift}

Raymond Pearlson of Miami, Florida, USA, invented the Syncrolift shiplift system in 1954. In 1979, the original company, named Pearlson Engineering, became Syncrolift Inc, which is a subsidiary of Rolls Royce, UK. The system essentially consists of a large platform, which can be lowered into water, a ship positioned over it and then the platform raised vertically above water along with the ship. It has three principal components: (1) a structural steel platform, (2) electrically powered wire rope hoists for raising and lowering the platform, and (3) an electric motor system to operate the system. Ships are dry docked on the platform using conventional procedure for setting the keel blocks and placing the bilge blocks. Ships raised above water are transported horizontally over rails to the desired location on land. The first Syncrolift was built in Miami, Florida in 1957, and it is still operational. By 1998, 220 Syncrolifts had been installed in 66 countries with lifting capacities from $101,600 \mathrm{~kg}$ (100 tons) to 60.9 million $\mathrm{kg}$ $(60,000$ tons $)$.

The advantages of Syncrolift over a conventional lock system are:

- $\quad$ Lower initial cost

- Shorter construction time

- Less susceptible to biological fouling

- No under water work 
- $\quad$ No use of fresh water for raising ship. However, freshwater may be lost through density current exchange when the lock doors are opened.

An artist's impression of the Syncrolift lock is shown in Figure 2-7. A schematic diagram of Syncrolift combined with flushing of salt water is shown in Figure 2-8. Dimensions of Syncrolift under consideration for Panama Canal site are shown in Figure 2-9. This information and additional details are available in an article published in the Dock and Harbor Authority, January/February 1999.

\section{Evaluation of Mitigation Options}

The following points need to be considered while evaluating alternatives for controlling salinity intrusion. Combination of alternatives may have to be considered to achieve the intended objectives.

- Construction feasibility

- Low initial cost

- Low operational cost

- Long life

- Ease of operation

- Low vessel throughput time

- Low increase in lake water salinity

- Low fresh water consumption 


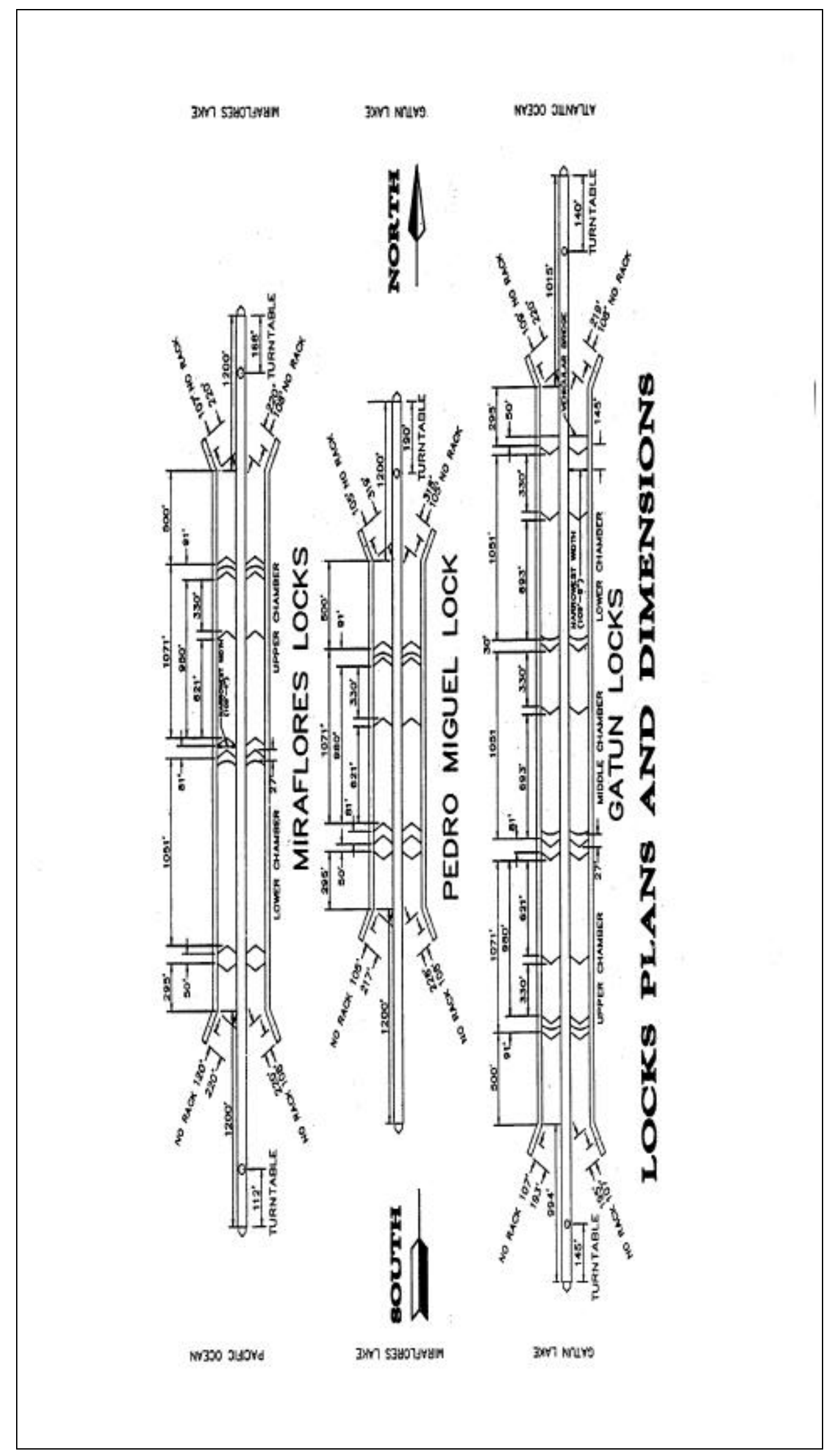

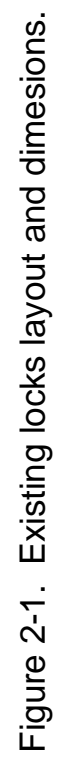




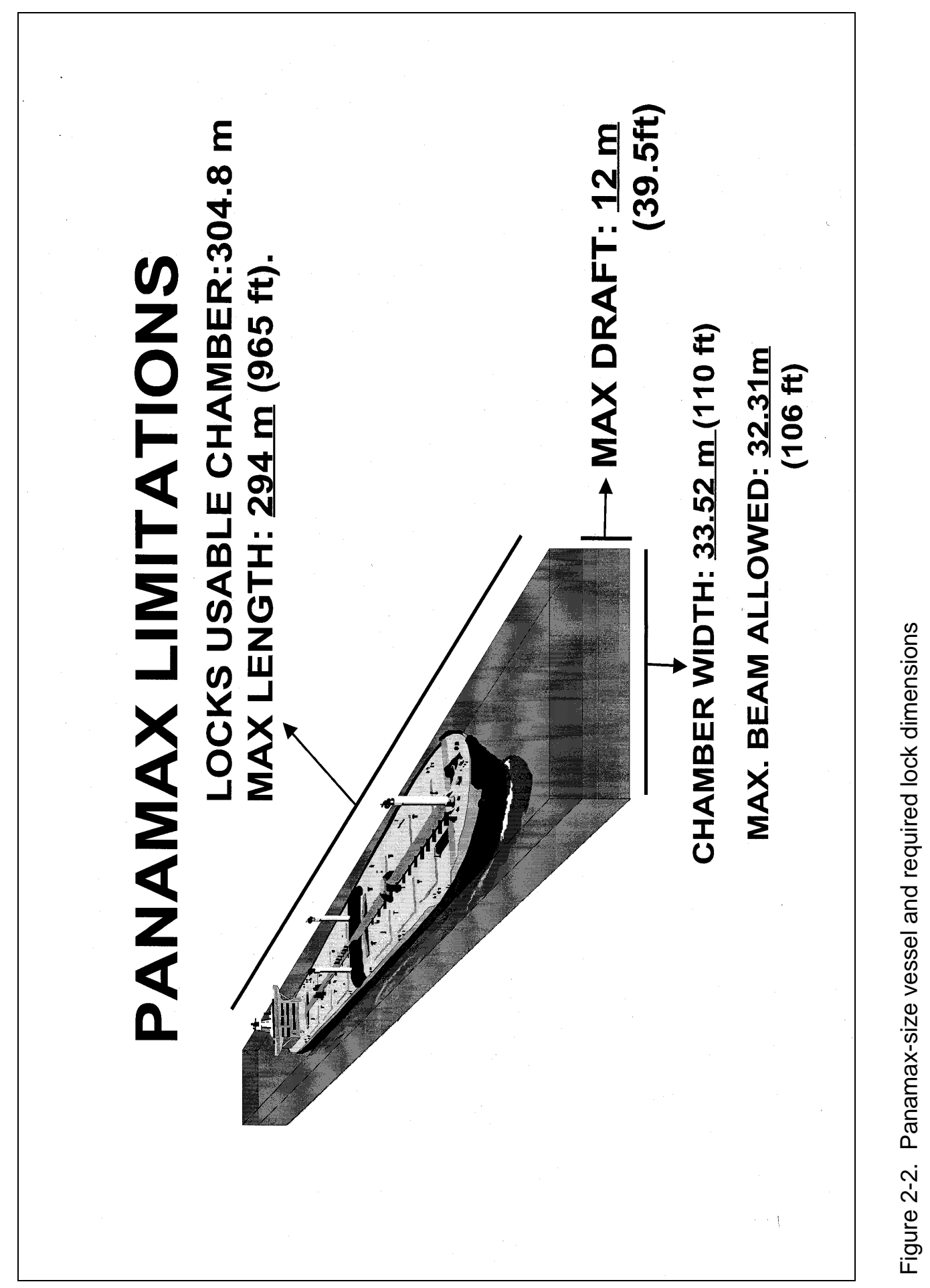




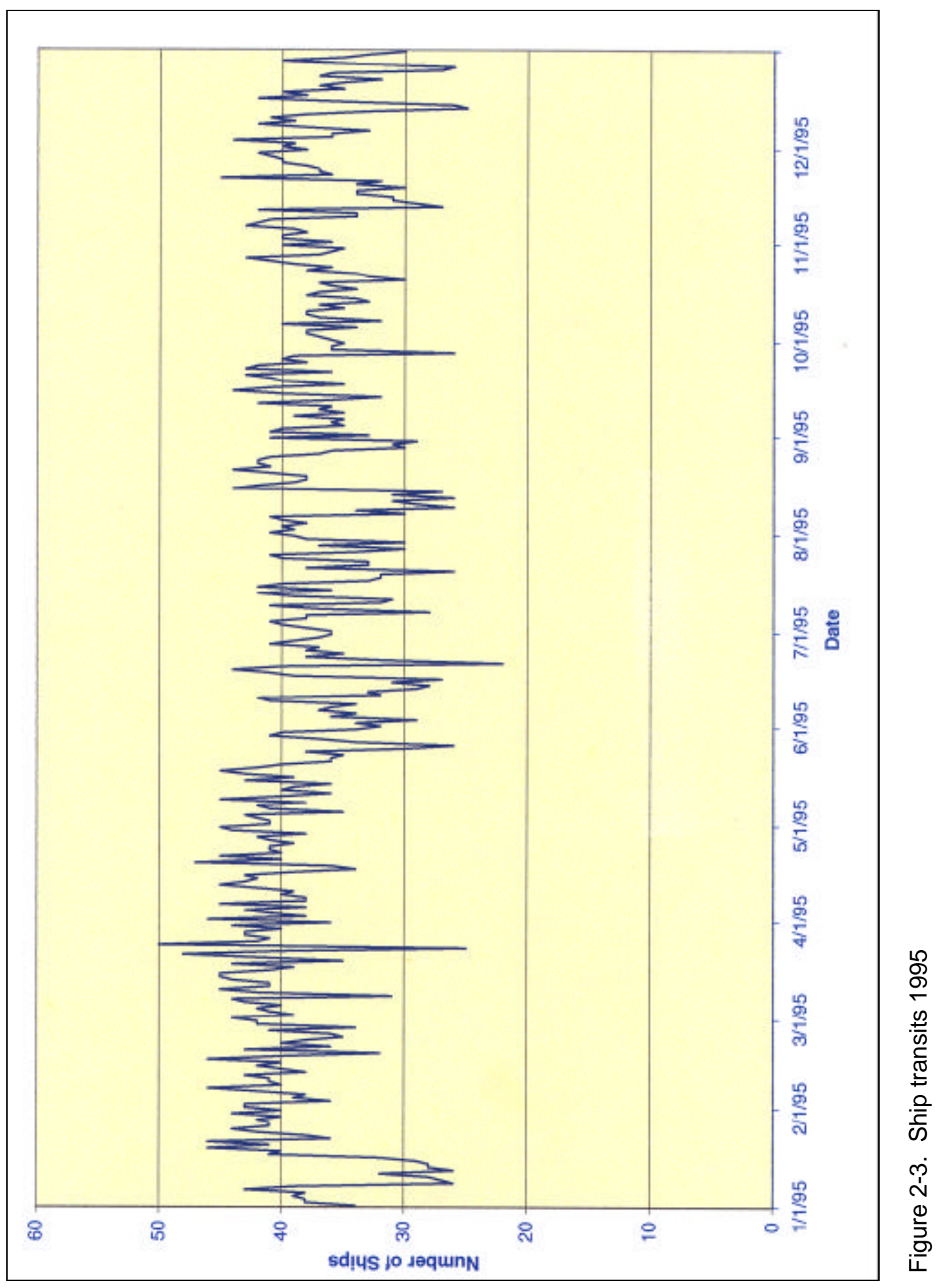




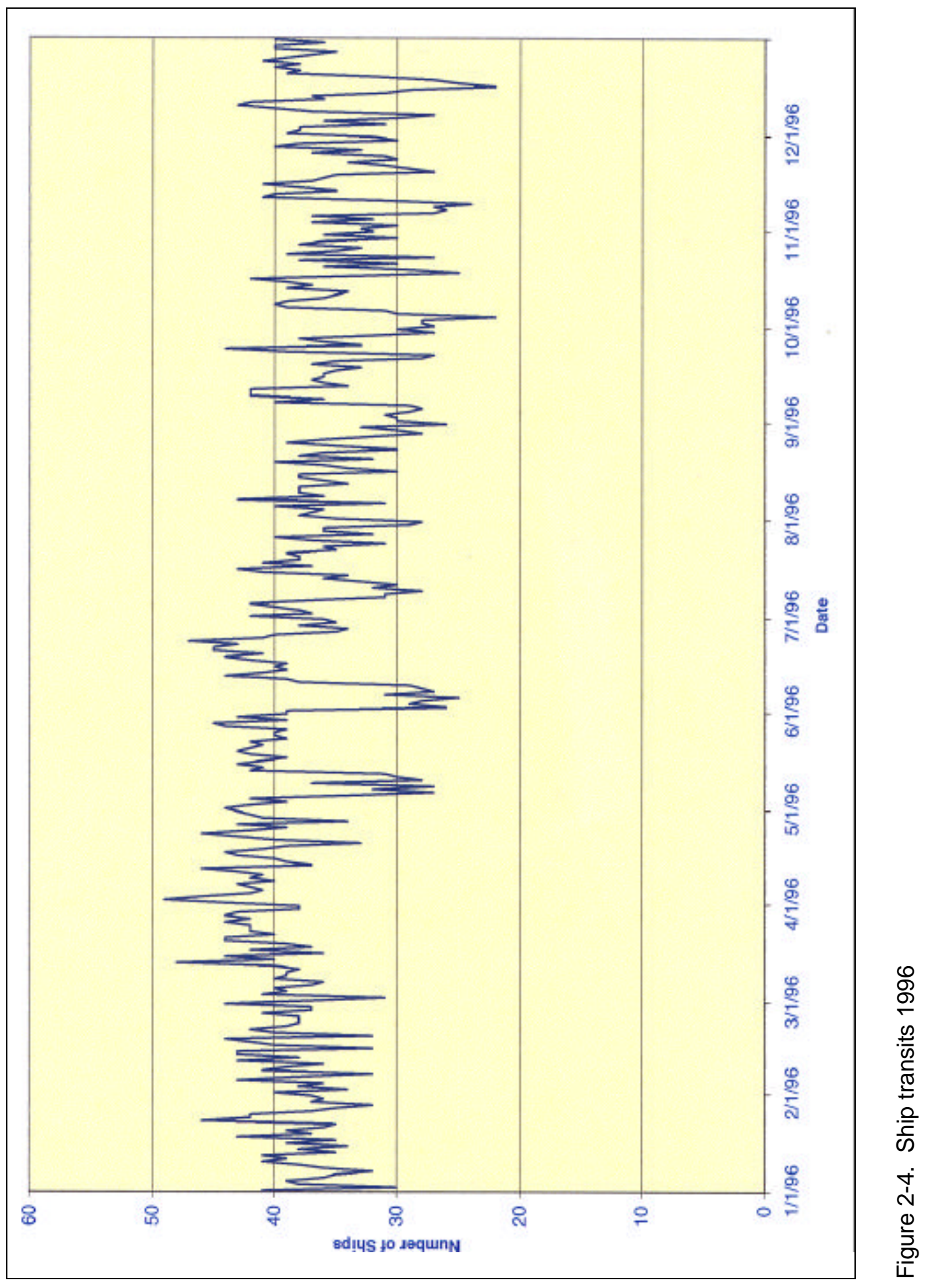




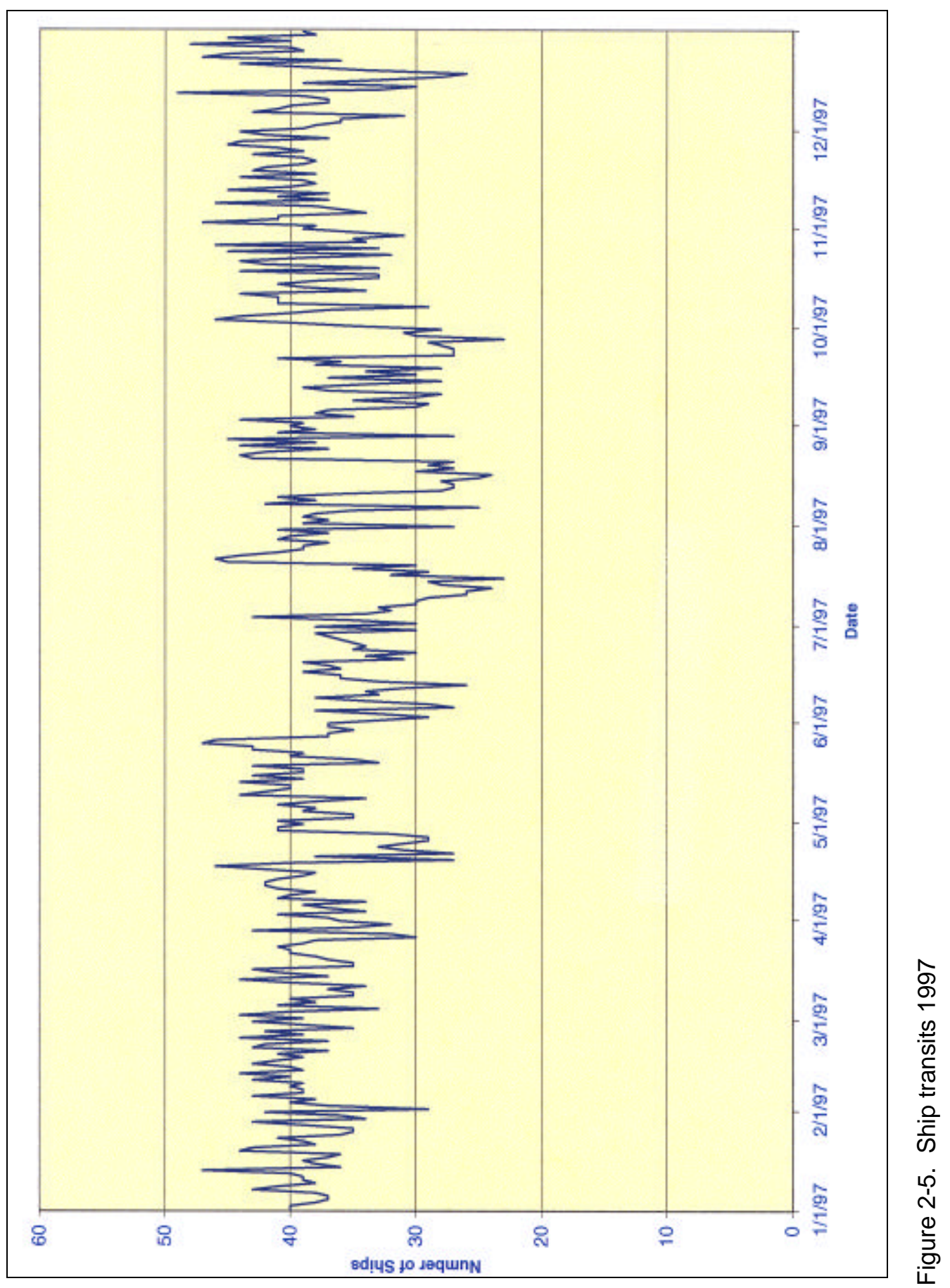




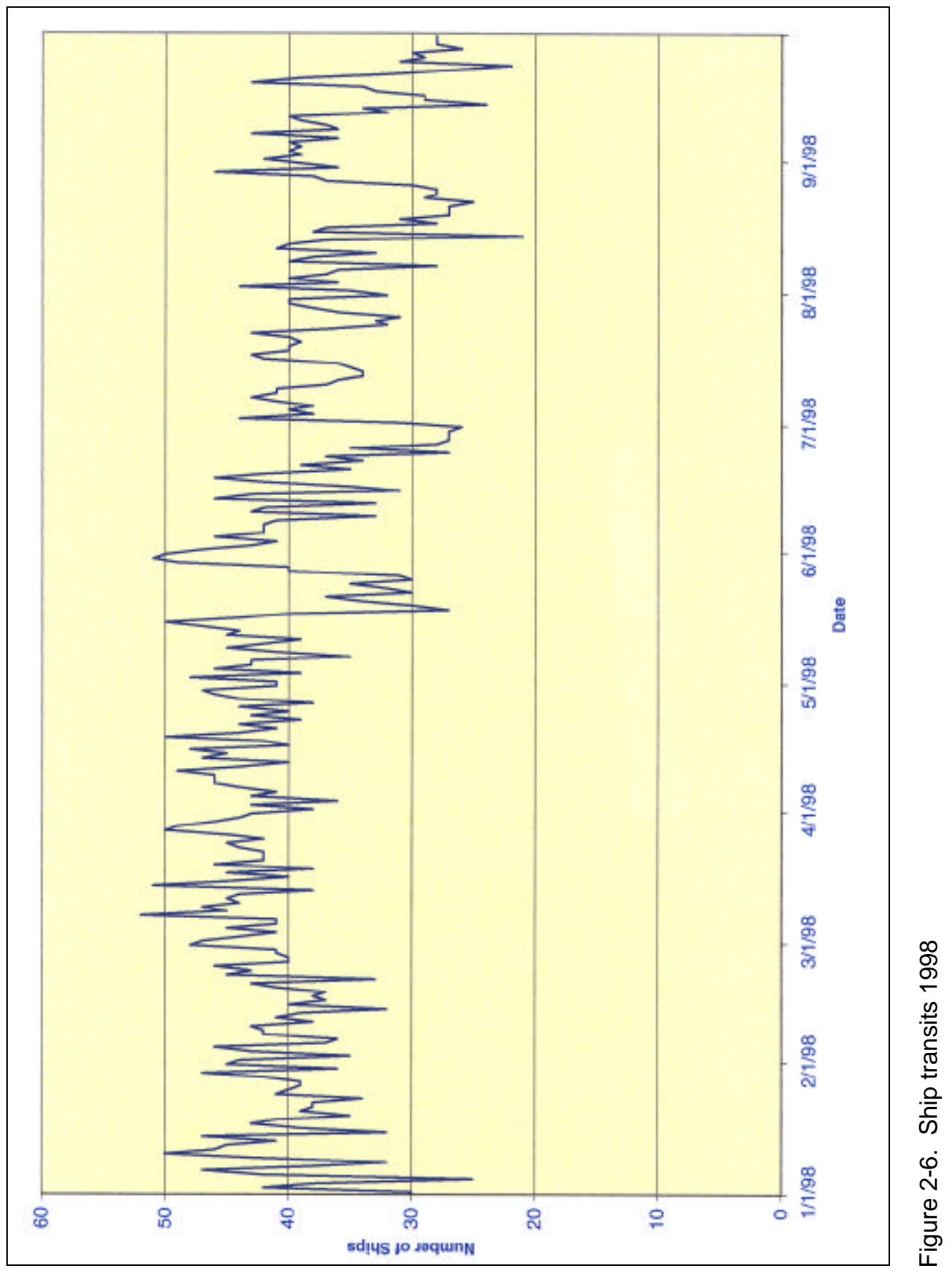




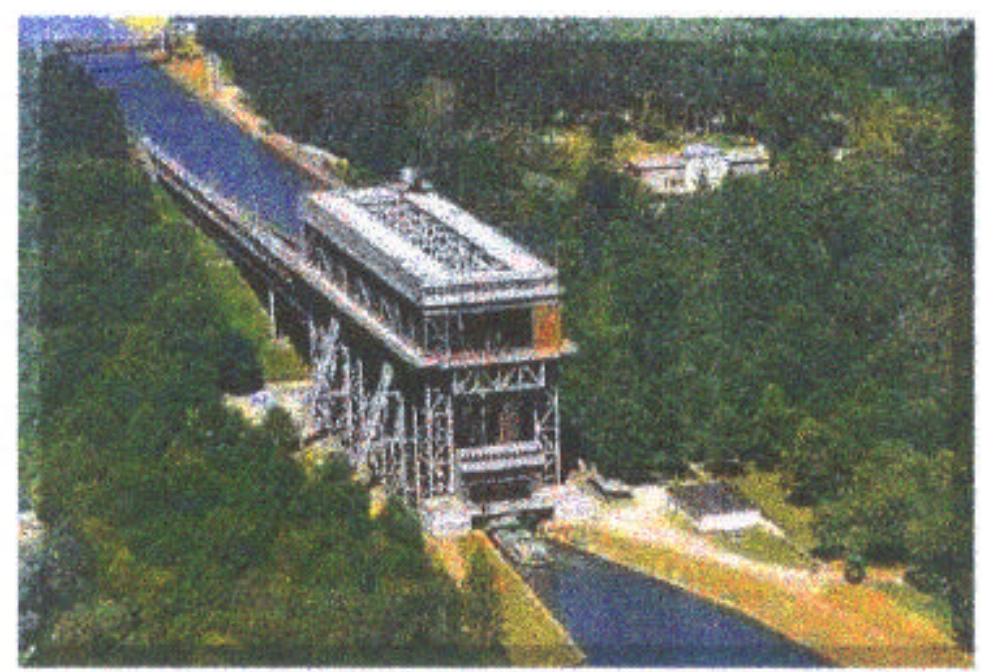

Figure 2-7. Artist's impression of a syncrolift lock. (Source: Syncrolift, Inc. Reprinted with permission.) 


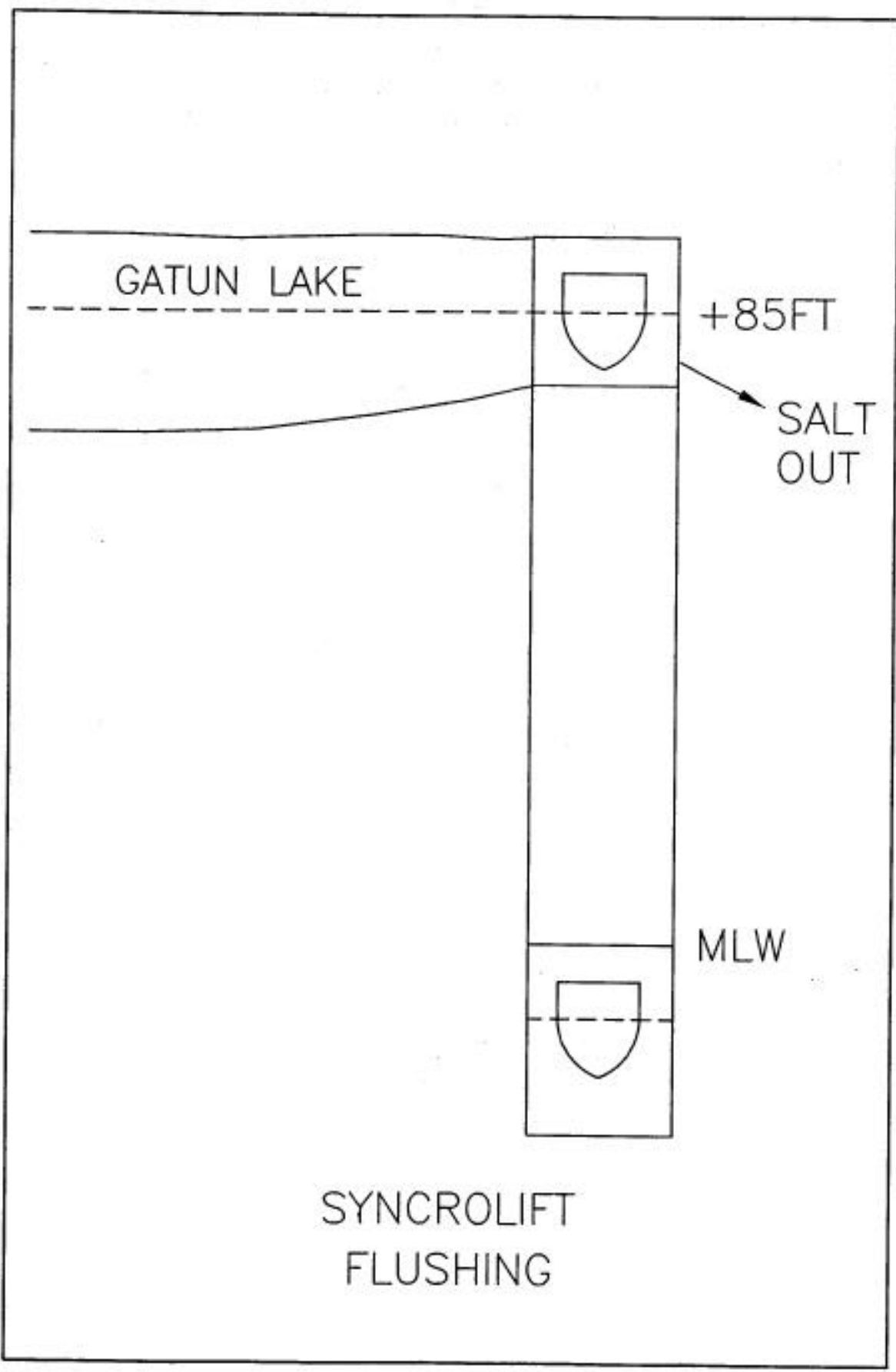

Figure 2-8. Schematic of Syncrolift Lock with flushing 


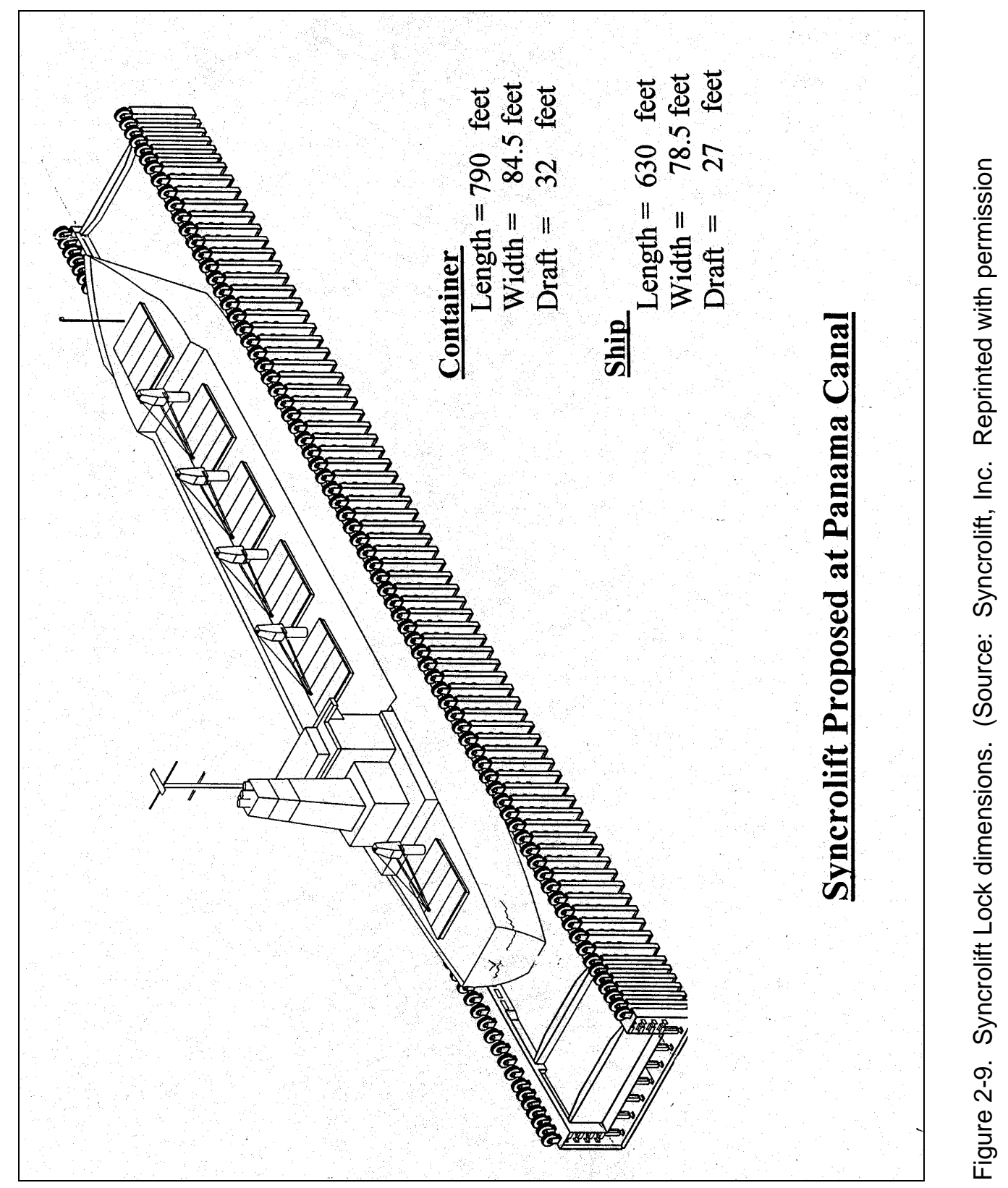




\section{Salt Loading and Freshwater Usage}

This section describes the process of salinity intrusion and some straightforward analytical methods for calculating the amount of salt transported into the canal through the locks and the amount of fresh water lost to the sea through the lockage process. The analytical methods are used to back-calculate the maximum salinity that can occur in the Syncrolift lock without increasing salinity intrusion into Gatún Lake and also to evaluate one option for conserving fresh water within the canal - recirculating lift water by collecting it in holding ponds and pumping it back for reuse.

\section{Salinity Intrusion}

Seawater contains about 35 grams of dissolved salts per $\mathrm{kg}$, with the primary salt constituents being chloride and sodium ions. This concentration is commonly referred to as "salinity," and was traditionally defined in terms of the mass concentration of halides (principally chlorine forms) in the water and expressed in parts per thousand (ppt). The standard was "Standard Seawater" or "Normal Water" taken from the North Sea and prepared for scientific use and instrument calibration by the Hydrographic Laboratories in Copenhagen, Denmark, and later by the Institute for Oceanographic Services, Wormly, England. The definition of salinity has changed slightly several times in response to practical demands and improved instrumentation.

In 1978 an international panel sponsored by the United Nations Educational, Scientific, and Cultural Organization (UNESCO) recommended that the old salinity definitions be replaced with a "Practical Salinity Scale" based on conductivity and employing no units, replacing the ppt units with the sign $* 10^{-3}$. The new scale was defined to yield values close to the old scales, so that $35 \mathrm{ppt}$ was about $35^{*} 10^{-3}$. That notation never caught on, but recently the units of "practical salinity units" (psu) have come into more common use. Nevertheless, in this report the traditional units of ppt are used to describe salinities defined under the new, conductivity-ratio-based definition.

The presence of dissolved salts increases the density of water, such that at $35 \mathrm{ppt}$, water is about 2 percent more dense than at $0 \mathrm{ppt}$. This seemingly small 
difference produces density currents. Given still salt water on one side of a barrier and fresh water on the other side, hydrostatic pressure is equal at the water surface, but the pressure on the salt water side increases more rapidly with depth. This pressure difference produces a net force toward the fresh water side, which will elevate the fresh water side if the barrier is removed. The combination of a raised fresh water level and increased salt water pressure with depth creates a flow of salt water under the fresh and of fresh water over the salt (see Part 5). The speed of the density underflow will be proportional to the square root of the density difference (Keulegan, 1969).

As noted previously, density flows will occur from lock chambers containing water that is either saltier or fresher than the water into which the gates are opened. When chamber containing fresh water is opened to a salt water basin, the salt water will flow into the chamber over the lower portion of the water column and fresh water will flow out over the upper portion of the column. If turbulence is present, the two layers will mix, at least partly.

\section{Calculating Salinity and Exchanges in the Locks}

The amount of salt intruding into Gatun Lake from lockages can be calculated by analytical or numerical means. In this section a set of simple mass balance equations are used to estimate salt loading and freshwater usage by the locks. For convenient reference, the six locks in the system are given the following notation:

L1: Lowest lock on the Pacific side

L2: Lock between Miraflores Lake and L1.

L3: Lock between Miraflores Lake and Gatun Lake. (Pedro Miguel)

L4: Highest lock directly connected to Gatun Lake.

L5: Middle lock on Atlantic side.

L6: Lowest lock connected to Atlantic Ocean.

A schematic longitudinal section of all the locks is given in Figure A-1 of Appendix A and in Table 2-1, which provide dimensions, lifts, and relevant levels of all the locks.

In these calculations, the following assumptions are made:

a. Tidal variation in sea level can be neglected. All computations are made for mean sea level (msl).

$b$. Mean sea level can be assumed to be roughly equivalent to the Canal's Precise Level Datum (PLD) without biasing the calculations.

c. Number of lockages is assumed to be the same as the number of ship transits.

d. An average blockage ratio of 0.8 is assumed for calculating submerged volume of ship from the length, beam and draft dimensions. 
e. Ocean salinity is assumed to be 35 parts per thousand. Observations (see Part 2) indicate that the local salinity near the lowest gate is much less than ocean salinity because fresh water from the lake is added to the sea for each ship transit and a transition zone exists between the lowest locks and the open sea. Based on the limited observations it is assumed that salinity just outside the lowest lock is $10 \mathrm{ppt}$ on the Pacific side and $8 \mathrm{ppt}$ on the Atlantic side.

f. Volume of water in Miraflores Lake is about 19 million cu m (670 million cft).

g. Net transfer of fresh water from the lake to the sea is about 0.2 million cu $\mathrm{m}$ (52 million gallons) per lockage, about 0.1 million cu $\mathrm{m}$ ( 26 million gallons) directly to fill the locks and about 0.1 million cu $\mathrm{m}$ (26 million gallons) pushed into the highest lock by density flow.

The following generic lock exchange equations can be used to characterize lock water and salt exchanges. Given the schematic lock shown in Figure 3-1, the left-hand-side (LHS) can be another lock or the sea and the right-hand-side (RHS) can be another lock or Miraflores Lake, Gaillard Cut, or Gatun Lake. The initial conditions (time $=0$ ) for lock volume and salinity are given by:

$$
\begin{aligned}
& S(0)=S_{0} \\
& V(0)=V_{T}-V_{L}
\end{aligned}
$$

where $V_{T}=$ total lock volume when filled to full lift height and $V_{L}=$ volume required to fill lock from minimum fill condition (min in Figure 3-1) to full lift height (max). From this initial condition, a one-way upbound ship transit from left to right occurs in four steps as given below. It is assumed that dissolved salt in the lock chamber is completely mixed ${ }^{1}$ at the end of each step.

Step 1: Open LHS gates, move ship into lock, close gates.

The displacement of the entering ship forces an equivalent net volume of water out of the lock to the LHS and density currents force opposite but equal exchanges of saltier water from the LHS for fresher water in the lock. The volume of water exchanged by density flows, $V_{L H S}$, can be expressed as a fraction of the water volume in the lock:

$$
V_{L H S}=E_{L H S}\left(V_{T}-V_{S}\right)
$$

where $E_{L H S}=$ an exchange coefficient between 0 and $1, V_{S}=$ displacement volume of the ship, and the net volume $\left(V_{T}-V_{S}\right)$ is the lesser of the two

\footnotetext{
${ }^{1}$ The complete mixing assumption is reasonable overall, since: a) lower salinity (thus usually lower density) filling water enters the chamber from the bottom and rises through higher salinity water with considerable turbulence; and b) during movement from one chamber to the next, ship propwash generates substantial mixing.
} 
connected chamber volumes. At the end of Step 1, the volume and salinity of the water inside the lock chamber are given by:

$$
\begin{aligned}
& \begin{array}{l}
V(1)=V(0)-V_{S} \\
=V_{t}=V_{L}
\end{array} \\
& S(1)=\frac{S(0) V(0)-S(0) V_{L H S}+S_{L H S} V_{L H S}-S(0) V_{S}}{V(1)} \\
& =\frac{S(0)\left(V(0)-V_{L H S}-V_{L}\right)+S_{L H S} V_{L H S}}{V(1)}
\end{aligned}
$$

where $S_{L H S}=$ salinity of the water outside the lock on the left-hand-side.

Step 2: Fill lock chamber

Applying conservation of mass for water and salt once more yields equations for volume and salinity within the chamber at the end of Step 2:

$$
\begin{aligned}
& V(2)=V_{T}-V_{S} \\
& S(2)=\frac{S(1) V(1)+S_{L} V_{L}}{V(2)}
\end{aligned}
$$

where $S_{L}=$ salinity of the lift water, which can be the salinity of the water outside the right-hand-side of the lock (either the next higher lock or lake) or, if a holding pond is employed, the salinity of water in the holding pond.

Step 3: Open right-hand-side (RHS) gates, move the ship out of the lock, and close the gates

During the step there is densimetric exchange with the RHS and water from the RHS flows into the lock to replace the ship displacement. The densimetric exchange volume is given by:

$$
V_{R H S}=E_{R H S}\left(V_{T}-V_{S}\right)
$$

At the end of the step the volume and salinity within the chamber are:

$$
\begin{aligned}
& V(3)=V_{T} \\
& S(3)=\frac{S(2)\left(V(2)-V_{R H S}\right)+S_{R H S}\left(V_{R H S}+V_{S}\right)}{V(3)}
\end{aligned}
$$

where $S_{R H S}=$ salinity of the water outside the RHS gates 
Step 4: Drain lift volume from the lock

At the end of step 4 the volume and salinity are given by:

$$
\begin{aligned}
& V(4)=V_{T}-V_{L} \\
& S(4)=S(3)
\end{aligned}
$$

and the lock is in the same fill configuration as the initial condition so that another cycle can begin.

By substitution of known values and algebraic manipulation, these equations can be used to derive an expression for the salinity in the lock chamber at the end of $N$ one-way, upbound lockages:

$$
\begin{aligned}
S_{N} & =S(0)+N(S(4)-S(0)) \\
= & S_{0}+N\left\{S_{0}\left[\frac{\left(V_{T}--V_{L}-V_{S}-V_{R H S}\right)\left(V_{T}-V_{S}-V_{L}-V_{L H S}\right)}{V_{T}\left(V_{T}-V_{S}\right)}-1\right]\right. \\
& +S_{L}\left[\frac{V_{L}\left(V_{T}-V_{S}-V_{R H S}\right)\left(V_{T}-V_{S}-V_{L}-V_{L H S}\right)}{V_{T}\left(V_{T}-V_{S}\right)\left(V_{T}-V_{L}\right)}\right] \\
& \left.+S_{R H S}\left[\frac{V_{R H S}+V_{S}}{V_{T}}\right]+S_{L H S}\left[\frac{V_{L H S}\left(V_{T}-V_{S}-V_{L}-V_{L H S}\right)}{V_{T}\left(V_{t}-V_{S}\right)}\right]\right\}
\end{aligned}
$$

A similar process can be used to develop expressions for the salinity with one-way downbound lockages and two-way lockages.

Equation 8 has been coded in spreadsheet format to facilitate evaluation of some salt mitigation alternatives for specific locks, and results for existing conditions are shown in Tables 3-1 and 3-2 for the Miraflores and Gatun Locks, respectively. The assumed initial condition was zero salinity in the locks and Miraflores Lake, and 10 ppt just outside the lowest lock on the Pacific side and 8 ppt on the Atlantic side (see Part 2). The exchange coefficients, $E_{L H S}$ and $E_{R H S}$, can be determined empirically by fitting Equation 8 to observed salinities in the Panama Canal Locks. Given the limited observations of Part 2, they were estimated to be about 0.5 (Keulegan, 1957), and Tables 3-1 and 3-2 show them to yield results that are reasonably consistent with the the observed salinities (Part 2). After about 20 lockages the lock chamber salinities have reached equilibrium values ranging from $0.1 \mathrm{ppt}$ in L4 to $3 \mathrm{ppt}$ in L1. Tuning of these coefficients will generate lock salinities in even closer agreement with the observations, but the limited number of observations and the simplicity of the method do not justify it. Appendix A employs the basic equations with the exchange coefficients transformed into transfer coefficients in order to precisely match observed lock salinities and then compute salt loadings and water flows through each set of locks. Those calculations show the salt loading to be extremely sensitive to the calculated in-lock salinities. For example, varying the ambient salinity of Miraflores Lake from $1.1 \mathrm{ppt}$ to $1.4 \mathrm{ppt}$ causes the net salt input to the lake to vary from $+17,000 \mathrm{lbs}$ per transit to $-44,000 \mathrm{lbs}$ per transit. A near-equilibrium salinity occurs if the lake has a salinity of $1.18 \mathrm{ppt}$. 


\begin{tabular}{|c|c|c|c|c|c|c|c|c|c|c|c|c|}
\hline \multicolumn{13}{|c|}{\begin{tabular}{||l} 
Table 3-1 \\
Pacific Locks Salinity
\end{tabular}} \\
\hline \multicolumn{2}{|c|}{ PARAMETER } & LHS & \multicolumn{2}{|c|}{ LOCK 1} & \multicolumn{2}{|c|}{ LOCK 2} & \multicolumn{2}{|c|}{ MIRAFLORES } & \multicolumn{2}{|c|}{ LOCK 3} & \multicolumn{2}{|l|}{ GATUN } \\
\hline \multicolumn{2}{|c|}{ TOTAL FILLED VOL (VT) cf } & & $9.02 \mathrm{E}+06$ & & $8.76 \mathrm{E}+06$ & & $8.70 \mathrm{E}+08$ & & $8.71 \mathrm{E}+06$ & & & \\
\hline \multicolumn{2}{|c|}{ LIFT VOL (VL) cf } & & $3.01 \mathrm{E}+06$ & & $3.30 \mathrm{E}+06$ & & $3.65 \mathrm{E}+06$ & & $3.65 E+06$ & & & \\
\hline \multicolumn{2}{|c|}{ SHIP VOL (VS) cf } & & $1.14 \mathrm{E}+06$ & & $1.14 \mathrm{E}+06$ & & $1.14 \mathrm{E}+06$ & & $1.14 \mathrm{E}+06$ & & & \\
\hline \multicolumn{2}{|c|}{ EXCHANGABLE VOL, cf } & & $6.01 \mathrm{E}+06$ & $5.46 \mathrm{E}+06$ & $5.46 \mathrm{E}+06$ & $5.46 \mathrm{E}+06$ & $8.66 \mathrm{E}+08$ & $5.06 \mathrm{E}+06$ & $5.06 \mathrm{E}+06$ & $5.06 \mathrm{E}+06$ & & \\
\hline \multicolumn{2}{|c|}{ VT-VL } & & $6.01 \mathrm{E}+06$ & & $5.46 \mathrm{E}+06$ & & $8.66 \mathrm{E}+08$ & & $5.06 \mathrm{E}+06$ & & & \\
\hline \multicolumn{2}{|l|}{ VT-VS } & & $7.88 \mathrm{E}+06$ & & $7.62 \mathrm{E}+06$ & & $8.69 \mathrm{E}+08$ & & $7.57 \mathrm{E}+06$ & & & \\
\hline \multicolumn{2}{|l|}{ VT-VL-VS } & & $4.87 \mathrm{E}+06$ & & $4.32 \mathrm{E}+06$ & & $8.65 \mathrm{E}+08$ & & $3.92 \mathrm{E}+06$ & & & \\
\hline $\begin{array}{l}\text { EXCHANGE CO } \\
\text { (ELHS \& ERHS) }\end{array}$ & $\begin{array}{l}\text { OEFS } \\
\text { 5) }\end{array}$ & 0.50 & 0.5 & 0.50 & 0.50 & 0.50 & 0.50 & 0.50 & 0.50 & 0.50 & 0.50 & \\
\hline $\begin{array}{l}\text { EXCHANGE VO } \\
\text { (VLHS \& VRHS }\end{array}$ & & & $3.01 \mathrm{E}+06$ & $2.73 E+06$ & $2.73 \mathrm{E}+06$ & $2.73 \mathrm{E}+06$ & $4.33 \mathrm{E}+08$ & $2.53 \mathrm{E}+06$ & $2.53 \mathrm{E}+06$ & $2.53 \mathrm{E}+06$ & & \\
\hline \begin{tabular}{|l|l|} 
TERM 1 & \\
\end{tabular} & So* & & $5.63 E-02$ & & 3.79E-02 & & 4.93E-01 & & 2.92E-02 & & & \\
\hline TERM 2 & $S L^{*}$ & & $9.07 \mathrm{E}-02$ & & 7.86E-02 & & $4.17 \mathrm{E}-03$ & & 7.69E-02 & & & \\
\hline TERM 3 & SLHS* & & $2.18 \mathrm{E}-01$ & & $2.00 \mathrm{E}-01$ & & 4.96E-01 & & $1.93 \mathrm{E}-01$ & & & \\
\hline TERM 4 & $\mathrm{SRHS}^{*}$ & & $4.29 \mathrm{E}-01$ & & $4.42 \mathrm{E}-01$ & & $4.22 \mathrm{E}-03$ & & $4.21 \mathrm{E}-01$ & & & \\
\hline LOCKAGES & $\begin{array}{r}\text { LHS SA } \\
\mathrm{pr} \\
\end{array}$ & & $\begin{array}{r}\text { LOCK } 15 \\
p\end{array}$ & $\begin{array}{ll}\text { ALINITY } \\
\text { t }\end{array}$ & $\begin{array}{r}\text { LOCK } 2 S \\
\mathrm{pr}\end{array}$ & $\begin{array}{l}\text { SALINITY } \\
\text { pt }\end{array}$ & $\begin{array}{l}\text { MIRAF } \\
\text { SALIN }\end{array}$ & $\begin{array}{l}\text { ORES } \\
\text { TY ppt }\end{array}$ & $\begin{array}{r}\text { LOCK } 3 \mathrm{SA} \\
\mathrm{ppt}\end{array}$ & ALINITY & $\begin{array}{r}\text { GATUN } \\
\text { SALINITY } p\end{array}$ & \\
\hline 0 & & 10.00 & & 3.05 & & \begin{tabular}{|l|}
0.00 \\
\end{tabular} & & 0.00 & & 0.00 & & 0 \\
\hline 1 & & 10.00 & & 2.35 & & 0.47 & & 0.23 & & 0.02 & & 0 \\
\hline 2 & & 10.00 & & 2.56 & & 0.65 & & 0.44 & & 0.03 & & 0 \\
\hline 3 & & 10.00 & & 2.66 & & 0.78 & & 0.61 & & 0.04 & & 0 \\
\hline 4 & & 10.00 & & 2.74 & & 0.89 & & 0.74 & & 0.05 & & 0 \\
\hline 5 & & 10.00 & & 2.80 & & 0.98 & & 0.85 & & 0.06 & & 0 \\
\hline 6 & & 10.00 & & 2.85 & & 1.05 & & 0.94 & & 0.06 & & 0 \\
\hline 7 & & 10.00 & & 2.88 & & 1.11 & & 1.01 & & 0.07 & & 0 \\
\hline 8 & & 10.00 & & 2.92 & & 1.15 & & 1.07 & & 0.07 & & 0 \\
\hline 9 & & 10.00 & & 2.94 & & 1.19 & & 1.12 & & 0.07 & & 0 \\
\hline 10 & & 10.00 & & 2.96 & & 1.22 & & 1.16 & & 0.08 & & 0 \\
\hline 11 & & 10.00 & & 2.98 & & 1.25 & & 1.19 & & 0.08 & & 0 \\
\hline 12 & & 10.00 & & 2.99 & & 1.27 & & 1.22 & & 0.08 & & 0 \\
\hline 13 & & 10.00 & & 3.00 & & 1.28 & & 1.24 & & 0.08 & & 0 \\
\hline 14 & & 10.00 & & 3.01 & & 1.29 & & 1.25 & & 0.08 & & 0 \\
\hline 15 & & 10.00 & & 3.02 & & 1.31 & & 1.27 & & 0.08 & & 0 \\
\hline 16 & & 10.00 & & 3.03 & & 1.31 & & 1.28 & & 0.08 & & 0 \\
\hline 17 & & 10.00 & & 3.03 & & 1.32 & & 1.29 & & 0.09 & & 0 \\
\hline 18 & & 10.00 & & 3.04 & & 1.33 & & 1.29 & & 0.09 & & 0 \\
\hline 19 & & 10.00 & & 3.04 & & 1.33 & & 1.30 & & 0.09 & & 0 \\
\hline 20 & & 10.00 & & 3.04 & & 1.33 & & 1.30 & & 0.09 & & 0 \\
\hline 21 & & 10.00 & & 3.04 & & 1.34 & & 1.31 & & 0.09 & & 0 \\
\hline 22 & & 10.00 & & 3.05 & & 1.34 & & 1.31 & & 0.09 & & 0 \\
\hline 23 & & 10.00 & & 3.05 & & 1.34 & & 1.31 & & 0.09 & & 0 \\
\hline 24 & & 10.00 & & 3.05 & & 1.34 & & 1.32 & & 0.09 & & 0 \\
\hline 25 & & 10.00 & & 3.05 & & 1.35 & & 1.32 & & 0.09 & & 0 \\
\hline 26 & & 10.00 & & 3.05 & & 1.35 & & 1.32 & & 0.09 & & 0 \\
\hline 27 & & 10.00 & & 3.05 & & 1.35 & & 1.32 & & 0.09 & & 0 \\
\hline 28 & & 10.00 & & 3.05 & & 1.35 & & 1.32 & & 0.09 & & 0 \\
\hline 29 & & 10.00 & & 3.05 & & 1.35 & & 1.32 & & 0.09 & & 0 \\
\hline 30 & & 10.00 & & 3.05 & & 1.35 & & 1.32 & & 0.09 & & 0 \\
\hline 31 & & 10.00 & & 3.05 & & 1.35 & & 1.32 & & 0.09 & & 0 \\
\hline 32 & & 10.00 & & 3.05 & & 1.35 & & 1.32 & & 0.09 & & 0 \\
\hline 33 & & 10.00 & & 3.05 & & 1.35 & & 1.32 & & 0.09 & & 0 \\
\hline 34 & & 10.00 & & 3.05 & & 1.35 & & 1.32 & & 0.09 & & 0 \\
\hline 35 & & 10.00 & & 3.05 & & 1.35 & & 1.32 & & 0.09 & & 0 \\
\hline 36 & & 10.00 & & 3.05 & & 1.35 & & 1.32 & & 0.09 & & 0 \\
\hline 37 & & 10.00 & & 3.05 & & 1.35 & & 1.32 & & 0.09 & & 0 \\
\hline 38 & & 10.00 & & 3.05 & & 1.35 & & 1.32 & & 0.09 & & 0 \\
\hline 39 & & 10.00 & & 3.05 & & 1.35 & & 1.32 & & 0.09 & & 0 \\
\hline 40 & & 10.00 & & 3.05 & & 1.35 & & 1.32 & & 0.09 & & 0 \\
\hline
\end{tabular}




\begin{tabular}{|c|c|c|c|c|c|c|c|c|c|c|}
\hline \multicolumn{11}{|c|}{$\begin{array}{l}\text { Table 3-2 } \\
\text { Atlantic Locks Salinity }\end{array}$} \\
\hline \multicolumn{2}{|c|}{ PARAMETER } & \multirow[t]{2}{*}{ LHS } & \multicolumn{2}{|c|}{ LOCK 6} & \multicolumn{2}{|c|}{ LOCK 5} & \multicolumn{2}{|c|}{ LOCK 4} & \multicolumn{2}{|c|}{ GATUN } \\
\hline \multicolumn{2}{|c|}{ TOTAL FILLED VOL (VT) cf } & & $9.36 \mathrm{E}+06$ & & $8.36 \mathrm{E}+06$ & & $8.48 \mathrm{E}+06$ & & & \\
\hline \multicolumn{2}{|c|}{ LIFT VOLUME (VL) cf } & & $3.24 \mathrm{E}+06$ & & $3.35 \mathrm{E}+06$ & & $3.65 \mathrm{E}+06$ & & & \\
\hline \multicolumn{2}{|c|}{ SHIP VOLUME (VS) cf } & & $1.14 \mathrm{E}+06$ & & $1.14 \mathrm{E}+06$ & & $1.14 \mathrm{E}+06$ & & & \\
\hline \multicolumn{2}{|c|}{ EXCHANGABLE VOL, cf } & & $6.12 \mathrm{E}+06$ & $5.01 \mathrm{E}+06$ & $5.01 \mathrm{E}+06$ & $5.01 \mathrm{E}+06$ & $4.83 \mathrm{E}+06$ & $4.83 \mathrm{e}+06$ & & \\
\hline \begin{tabular}{|l|}
$\mathrm{VT}-\mathrm{VL}$ \\
\end{tabular} & & & $6.12 \mathrm{E}+06$ & & $5.01 \mathrm{E}+06$ & & $4.83 \mathrm{E}+06$ & & & \\
\hline VT-VS & & & $8.22 \mathrm{E}+06$ & & $7.22 \mathrm{E}+06$ & & $7.34 \mathrm{E}+06$ & & & \\
\hline VT-VL-VS & & & $4.98 \mathrm{E}+06$ & & $3.87 \mathrm{E}+06$ & & $3.69 \mathrm{E}+06$ & & & \\
\hline \multicolumn{2}{|l|}{$\begin{array}{l}\text { EXCHANGE COEFS } \\
\text { (ELHS\&ERHS) } \\
\end{array}$} & 0.5 & 0.5 & 0.50 & 0.50 & 0.50 & 0.50 & 0.50 & 0.50 & \\
\hline \multicolumn{2}{|l|}{$\begin{array}{l}\text { EXCHANGE VOL } \\
\text { (VLHS\&VRHS) }\end{array}$} & & $3.06 \mathrm{E}+06$ & $2.50 \mathrm{E}+06$ & $2.50 \mathrm{E}+06$ & $2.50 \mathrm{E}+06$ & $2.42 \mathrm{E}+06$ & $2.42 \mathrm{E}+06$ & & \\
\hline TERM 1 & \multicolumn{2}{|l|}{$\mathrm{SO}^{*}$} & $6.18 \mathrm{E}-02$ & & $3.08 \mathrm{E}-02$ & & $2.61 \mathrm{E}-02$ & & & \\
\hline TERM 2 & \multicolumn{2}{|l|}{$\mathrm{SL}^{*}$} & $1.04 \mathrm{E}-01$ & & $7.58 \mathrm{E}-02$ & & $7.48 \mathrm{E}-02$ & & & \\
\hline TERM 3 & \multicolumn{2}{|l|}{$\mathrm{SLHS}^{*}$} & $2.27 \mathrm{E}-01$ & & $1.96 \mathrm{E}-01$ & & $1.91 \mathrm{E}-01$ & & & \\
\hline TERM 4 & \multicolumn{2}{|l|}{$\mathrm{SRHS}^{*}$} & 3.89E-01 & & 4.36E-01 & & 4.19E-01 & & & \\
\hline LOCKAGES & $\mathrm{LH} s$ & NITY & $\begin{array}{r}\text { LOCK } 6 \text { SA } \\
\text { ppt }\end{array}$ & _INITY & $\begin{array}{r}\text { LOCK } 5 \text { SA } \\
\text { ppt }\end{array}$ & INITY & $\begin{array}{r}\text { LOCK } 45 \\
p\end{array}$ & LINITY & $\begin{array}{r}\text { GATU } \\
\text { SALINIT }\end{array}$ & \\
\hline 0 & & 8.00 & & 0.00 & & 0.00 & & 0.0 & & 0 \\
\hline 1 & & 8.00 & & 1.82 & & 0.36 & & 0.07 & & 0 \\
\hline 2 & & 8.00 & & 2.11 & & 0.46 & & 0.09 & & 0 \\
\hline 3 & & 8.00 & & 2.18 & & 0.49 & & 0.10 & & 0 \\
\hline 4 & & 8.00 & & 2.19 & & 0.49 & & 0.10 & & 0 \\
\hline 5 & & 8.00 & & 2.20 & & 0.49 & & 0.10 & & 0 \\
\hline 6 & & 8.00 & & 2.20 & & 0.50 & & 0.10 & & 0 \\
\hline 7 & & 8.00 & & 2.20 & & 0.50 & & 0.10 & & 0 \\
\hline 8 & & 8.00 & & 2.20 & & 0.50 & & 0.10 & & 0 \\
\hline 9 & & 8.00 & & 2.20 & & 0.50 & & 0.10 & & 0 \\
\hline 10 & & 8.00 & & 2.20 & & 0.50 & & 0.10 & & 0 \\
\hline 11 & & 8.00 & & 2.20 & & 0.50 & & 0.10 & & 0 \\
\hline 12 & & 8.00 & & 2.20 & & 0.50 & & 0.10 & & 0 \\
\hline 13 & & 8.00 & & 2.20 & & 0.50 & & 0.10 & & 0 \\
\hline 14 & & 8.00 & & 2.20 & & 0.50 & & 0.10 & & 0 \\
\hline 15 & & 8.00 & & 2.20 & & 0.50 & & 0.10 & & 0 \\
\hline 16 & & 8.00 & & 2.20 & & 0.50 & & 0.10 & & 0 \\
\hline 17 & & 8.00 & & 2.20 & & 0.50 & & 0.10 & & 0 \\
\hline 18 & & 8.00 & & 2.20 & & 0.50 & & 0.10 & & 0 \\
\hline 19 & & 8.00 & & 2.20 & & 0.50 & & 0.10 & & 0 \\
\hline 20 & & 8.00 & & 2.20 & & 0.50 & & 0.10 & & 0 \\
\hline 21 & & 8.00 & & 2.20 & & 0.50 & & 0.10 & & 0 \\
\hline 22 & & 8.00 & & 2.20 & & 0.50 & & 0.10 & & 0 \\
\hline 23 & & 8.00 & & 2.20 & & 0.50 & & 0.10 & & 0 \\
\hline 24 & & 8.00 & & 2.20 & & 0.50 & & 0.10 & & 0 \\
\hline 25 & & 8.00 & & 2.20 & & 0.50 & & 0.10 & & 0 \\
\hline 26 & & 8.00 & & 2.20 & & 0.50 & & 0.10 & & 0 \\
\hline 27 & & 8.00 & & 2.20 & & 0.50 & & 0.10 & & 0 \\
\hline 28 & & 8.00 & & 2.20 & & 0.50 & & 0.10 & & 0 \\
\hline 29 & & 8.00 & & 2.20 & & 0.50 & & 0.10 & & 0 \\
\hline 30 & & 8.00 & & 2.20 & & 0.50 & & 0.10 & & 0 \\
\hline 31 & & 8.00 & & 2.20 & & 0.50 & & 0.10 & & 0 \\
\hline 32 & & 8.00 & & 2.20 & & 0.50 & & 0.10 & & 0 \\
\hline 33 & & 8.00 & & 2.20 & & 0.50 & & 0.10 & & 0 \\
\hline 34 & & 8.00 & & 2.20 & & 0.50 & & 0.10 & & 0 \\
\hline 35 & & 8.00 & & 2.20 & & 0.50 & & 0.10 & & 0 \\
\hline 36 & & 8.00 & & 2.20 & & 0.50 & & 0.10 & & 0 \\
\hline 37 & & \begin{tabular}{|l|}
8.00 \\
\end{tabular} & & 2.20 & & 0.50 & & 0.10 & & 0 \\
\hline
\end{tabular}


Tables 3-3 and 3-4 list the results of the salt loading calculations.

\begin{tabular}{|c|c|c|}
\hline \multicolumn{3}{|c|}{$\begin{array}{l}\text { Table 3-3 } \\
\text { Estimates of Salinities Resulting from Ships Transiting from Pacifi } \\
\text { Entrance }\end{array}$} \\
\hline Location and stage & Salinity (ppt) & Transfer Coefficient (\%) \\
\hline Pacific Ocean & 35.0 & 100.0 \\
\hline $\begin{array}{l}\text { Pacific Ocean } \\
\text { just outside L1 }\end{array}$ & 10.0 & 28.6 \\
\hline $\begin{array}{l}\text { Inside Lock L1 } \\
\text { after ship enters }\end{array}$ & 8.0 & 22.9 \\
\hline $\begin{array}{l}\text { Inside Lock L1 } \\
\text { after full lift }\end{array}$ & 5.5 & 15.8 \\
\hline $\begin{array}{l}\text { Inside Lock L2 } \\
\text { after ship enters }\end{array}$ & 1.5 & 4.3 \\
\hline $\begin{array}{l}\text { Inside Lock L2 } \\
\text { after full lift }\end{array}$ & 1.3 & 3.7 \\
\hline $\begin{array}{l}\text { Inside Lock L2 } \\
\text { after ship leaves }\end{array}$ & 1.0 & 2.9 \\
\hline Miraflores Lake & 1.0 & 2.9 \\
\hline $\begin{array}{l}\text { Inside Lock L3 } \\
\text { after ship enters }\end{array}$ & 0.3 & 0.7 \\
\hline $\begin{array}{l}\text { Inside Lock L3 } \\
\text { after full lift }\end{array}$ & 0.1 & 0.4 \\
\hline
\end{tabular}

\begin{tabular}{||l|l|l||}
\hline \multicolumn{3}{|l|}{$\begin{array}{l}\text { Table 3-4 } \\
\text { Estimate of salt transfer coefficients from Atlantic Entrance }\end{array}$} \\
\hline \hline Location and stage & Salinity (ppt) & Transfer coefficient \%) \\
\hline \hline Atlantic Ocean & 35.0 & 100.0 \\
\hline $\begin{array}{l}\text { Atlantic Ocean } \\
\text { just outside L6 }\end{array}$ & 10.0 & 28.6 \\
\hline $\begin{array}{l}\text { Inside Lock L6 } \\
\text { after ship enters }\end{array}$ & 8.0 & 22.8 \\
\hline $\begin{array}{l}\text { Inside Lock L6 } \\
\text { after full lift }\end{array}$ & 5.4 & 15.6 \\
\hline $\begin{array}{l}\text { Inside Lock L5 } \\
\text { after ship enters }\end{array}$ & 1.5 & 4.3 \\
\hline $\begin{array}{l}\text { Inside Lock L5 } \\
\text { after full lift }\end{array}$ & 0.8 & 2.3 \\
\hline $\begin{array}{l}\text { Inside Lock L4 } \\
\text { after ship enters }\end{array}$ & 0.2 & 0.4 \\
\hline $\begin{array}{l}\text { Inside Lock L4 } \\
\text { after full lift }\end{array}$ & 0.1 & 0.2 \\
\hline \hline
\end{tabular}




\section{Zero-Dimensional Model of Gatun Lake Salinity}

Using the basic approach given in the above exchange equations, a zeroorder numerical model ${ }^{1}$ was developed to describe the salinity accumulation in Gatun Lake. The model computes the salinity of Gatun Lake based upon the inflow of fresh water from Madden Lake, local tributaries, exchange with the Pedro Miguel and Gatun locks, and the influx of salt from the proposed Syncrolift Locks on both ends of the canal. Equation 9 shows the mass balance equation used for the model.

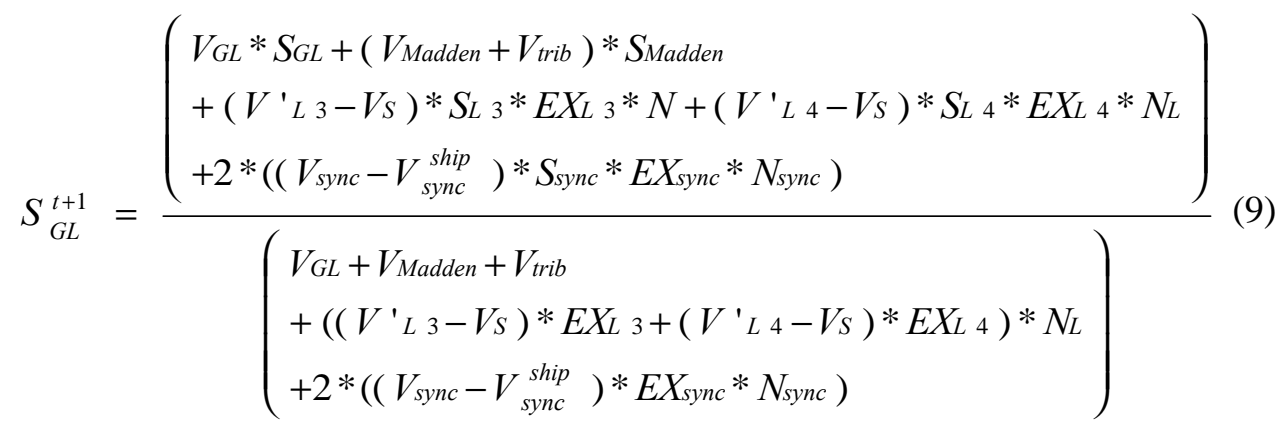

where $S_{G L}{ }^{t+1}$ is salinity in Gatun Lake at the end of the time step, $S_{G L} i s$ the salinity in Gatun Lake at the beginning of the time step and $\mathrm{V}_{\mathrm{GL}}$ is the volume of Gatun Lake; $V_{\text {Madden }}$ and $V_{\text {trib }}$ are volumetric inflows into Gatun Lake from Lake Madden and local tributaries, $S_{\text {Madden }}$ is the salinity of the inflows from Madden Lake and the local tributaries; $V_{S}$ is ship volume, $V \mathbb{N}_{3}, S_{L 3}$, and $E X_{L 3}$ are the lock volume, salinity, and average exchange ratio for lock 3 (Pedro Miguel Locks); $V N_{4}, S_{L 4}$, and $E X_{L 4}$ are the lock volume, salinity, and exchange ratio for L4 (Uppermost lock at Gatun Locks); $N_{L}$ is the number of lockages per time interval at the Gatun or Pedro Miguel Locks; and $V_{\text {sync }}, V_{\text {sync }}^{\text {ship }}, S_{\text {sync }}, E X_{\text {sync }}$, and $N_{\text {sync }}$ are the lock volume, ship volume, salinity, exchange ratio, and number of lockages per time interval for the Syncrolift facilities.

The observed salinity in and around the L1 (Miraflores Locks) provides a means of estimating the in-lock salinity of the Pedro Miguel Locks. The salinity of the brackish water seaward of L1 was measured at 8-10 ppt, a reduction by a factor of nearly 4 compared to seawater. It seems likely that the Miraflores Lake's salinities would demonstrate similar tendencies in the vicinity of Pedro Miguel Locks. Thus, the salinity at the entrance to L3 would be less than $0.7 \mathrm{ppt}$ by a factor of $3-4$, estimated at $0.200 \mathrm{ppt}$. The dilution that occurs during filling of L3 with fresh water will further reduce the salinity exposed to Gatun Lake to approximately $0.100 \mathrm{ppt}$.

Using this loading rate and the zero-order model, a steady-state salinity can be estimated for Gatun Lake at about $0.030 \mathrm{ppt}$ (Figure 3-2), which is well below the maximum salinity for drinking water of $0.250 \mathrm{ppt}$ and at an appropriate level,

\footnotetext{
${ }^{1}$ EXCEL spreadsheet model entitled Lake Gatun Zero-Order Salinity Intrusion Model v1.1 Sep 1999.
} 
since there are no reported salinity problems within Gatun Lake. The zero-order model also shows the time scale of salinity equilibrium into Gatun Lake to be on the order of 6-10 years. Table 3-5 gives the conditions used in this calculation and for other examples presented in subsequent figures.

\begin{tabular}{|c|c|c|c|c|c|}
\hline \multicolumn{6}{|c|}{$\begin{array}{l}\text { Table 3-5 } \\
\text { Data Used in Zero-Order Model Analysis }\end{array}$} \\
\hline Location/Process & Variable & Case 1 & Case 2 & Case 3 & Case 4 \\
\hline Gatun Lake & Time interval & \multicolumn{4}{|l|}{$1 \mathrm{yr}$} \\
\hline & Initial salinity, ppt & \multicolumn{4}{|c|}{0} \\
\hline & Volume, cf & \multicolumn{4}{|c|}{$1.82 \mathrm{E}+11$} \\
\hline \multirow[t]{4}{*}{$\begin{array}{l}\text { Madden Lake and } \\
\text { Tributary Inflow } \\
\text { Average }\end{array}$} & Annual spill volume, of & \multicolumn{4}{|c|}{$5.73 E+09$} \\
\hline & Annual power volume, cf & \multicolumn{4}{|c|}{$6.66 \mathrm{E}+10$} \\
\hline & Annual Tributary Volumes, cf & \multicolumn{4}{|c|}{$4.53 \mathrm{E}+10$} \\
\hline & Salinity, ppt & \multicolumn{4}{|c|}{0} \\
\hline \multirow[t]{4}{*}{$\begin{array}{l}\text { Exchange during } \\
\text { lift operations } \\
\text { Pedro Miguel } \\
\text { Locks }\end{array}$} & Annual lock volume, cf & \multicolumn{4}{|c|}{$5.12 \mathrm{E}+10$} \\
\hline & Exchange coefficient & \multicolumn{4}{|c|}{0.5} \\
\hline & Lock salinity, ppt & \multicolumn{4}{|l|}{0.1} \\
\hline & Number of lockages/day & \multicolumn{4}{|l|}{38} \\
\hline \multirow[t]{4}{*}{$\begin{array}{l}\text { Exchange during } \\
\text { lift operations } \\
\text { Gatun Locks }\end{array}$} & Annual lock volume, cf & \multicolumn{4}{|c|}{$5.45 \mathrm{E}+10$} \\
\hline & Exchange coefficient & \multicolumn{4}{|c|}{0.5} \\
\hline & Lock salinity, ppt & \multicolumn{4}{|l|}{0.1} \\
\hline & Number of lockages/day & \multicolumn{4}{|l|}{38} \\
\hline \multirow[t]{4}{*}{$\begin{array}{l}\text { Exchange during } \\
\text { lift operations } \\
\text { Miraflores syncrolift }\end{array}$} & Annual lock volume, cf & 0 & $8.74 \mathrm{E}+0 \varsigma$ & & \\
\hline & Exchange coefficient & 0 & 0.5 & & \\
\hline & Lock salinity, ppt & 0 & 35 & 4.5 & 0.3 \\
\hline & Number of lockages/day & \multicolumn{4}{|l|}{20} \\
\hline \multirow[t]{4}{*}{$\begin{array}{l}\text { Exchange during } \\
\text { lift operations } \\
\text { Gatun Syncrolift } \\
\end{array}$} & Annual lock volume, cf & 0 & $8.74 \mathrm{E}+0 \mathrm{~s}$ & & \\
\hline & Exchange coefficient & \multicolumn{4}{|l|}{0.5} \\
\hline & Lock salinity & 0 & 35 & 4.5 & 0.3 \\
\hline & Number of lockages & \multicolumn{4}{|l|}{20} \\
\hline
\end{tabular}

The Syncrolift facilities were added to the loading equation with an exchange coefficient of 50 percent, similar to the conventional locks. Its volume was based on dimensions of $243.8 \mathrm{~m}(800 \mathrm{ft})$ long by $26.9 \mathrm{~m} \quad(88.5 \mathrm{ft})$ wide by $9.8 \mathrm{~m}$ (32 ft) deep, which will contain a ship with a displacement of 30,242 cu m (1.068 million cubic feet). With an in-lock salinity of $35.0 \mathrm{ppt}$ (seawater), the steady state condition within Gatun Lake would be about $1.7 \mathrm{ppt}$ (Figure 3-3) for 20 lockages per day. Even for a much lower salinity loading of $10 \mathrm{ppt}$ (brackish water outside of Miraflores Locks), the steady state concentration is estimated at $0.500 \mathrm{ppt}$, which is double the drinking water maximum of $0.250 \mathrm{ppt}$. These results clearly indicate that, without mitigating technology, salinity in Gatun Lake could become unacceptably high once additional locks are put into operation. 
Varying the salinity of the Syncrolift lock provides insight into the potential impacts on Gatun Lake salinity. Without exceeding the drinking water maximum in Gatun Lake, the allowable salinity in the Syncrolift Lock is approximately $4.5 \mathrm{ppt}$ (Figure 3-4). However, if an allowable increase in Gatun Lake salinity of $0.010 \mathrm{ppt}$ is adopted (from 0.030 to $0.040 \mathrm{ppt}$ ), then the salinity within the Syncrolift Lock could not exceed 0.300 ppt (Figure 3-5).

\section{Recirculation of Lift Water in Holding Ponds}

In this scenario, depicted schematically in Figure 3-6, the lockage process consists of the steps listed above for a one-way transit upbound, and when the uppermost lock (L3 or L4) is filled, part of the lift volume is drawn from an upper holding pond and part from Gatun Lake. When the lowest lock (L1 or L6) is drained to accept the next ship at sea level, the lift volume is drained into the lower holding pond. Water from the lower holding pond is pumped to the upper pond for reuse.

In a recirculation operation, the salinity of the water used to fill the uppermost lock will be the salinity of the upper holding pond, which at the end of one lockage is given by:

$$
S_{L}=S_{U H P}(1)=\frac{S_{U H P}(0) V_{U H P}(0)-S_{U H P}(0) V_{L}+V_{P} S_{L H P}(0)}{V_{U H P}(1)}
$$

where the numbers in parentheses indicate the lockage number, $S_{U H P}$ is salinity of the upper pond, $S_{L H P}$ is salinity of the lower pond, $V_{P}$ is the water volume pumped from the lower pond to the upper pond during one lockage, and $V_{U H P}$ is volume of the upper pond, given by:

$$
V_{U H P}(1)=V_{U H P}(0)-V_{L}+V_{P}
$$

The salinity of the lower holding pond after one lockage will be:

$$
S_{L H P}(1)=\frac{S_{L H P}(0) V_{L H P}(0)+S_{L L}(0) V_{L}-S_{L H P}(0) V_{P}}{V_{L H P}(1)}
$$

where $S_{L L}$ is the salinity of the lowest lock chamber at the end of a lockage and $V_{L H P}$ is volume of the lower holding pond, given by:

$$
V_{L H P}(1)=V_{L H P}(0)+V_{L}-V_{P}
$$

During each one-way lockage, the volume of fresh water consumed by the existing procedure over $\mathrm{N}$ lockages can be approximated by: 


$$
V_{F}(N)=\sum_{n-1}^{N}\left[V_{L}(1-F)+V_{R H S}, H L+V_{S}\right]
$$

where $V_{R H S, H L}$ is the right-hand-side exchange volume for the highest lock. With the holding pond recirculation procedure, the freshwater consumption will be:

$$
V_{F, P}(N)=V_{U H P}+\sum_{n=1}^{N}\left[V_{L}(1-F)+V_{R H S}, H L+V_{S}\right]
$$

where $F$ is the fraction of the lift volume drawn from the upper holding pond.

More fresh water will be consumed by two-way lockages than by one-way, since an extra lift volume is used to fill one lock chamber that cannot be filled from the next higher lock, but the ratio of the two volumes (Equation 15 divided by 14) for one-way lockage can be used to approximate the overall savings in fresh water consumption.

Equation 8 and Equations 10-15, coded in a spreadsheet ${ }^{1}$ and combined with the following assumptions, provide a tool for examining the salinity and fresh water usage effects of this operation. The additional assumptions are:

a. Each pond is well-mixed at the end of each lockage.

$b$. The salinity just seaward of the lowest locks is proportional to the salinity of the water in the lowest lock chamber, but cannot rise above sea salinity of $35 \mathrm{ppt}$.

c. The small differences in individual lock lift volumes is neglected.

Assumption $b$ above is based on the observation that salinities just seaward of the lowest locks were just 8 to $10 \mathrm{ppt}$ instead of $35 \mathrm{ppt}$, apparently because of dilution with freshwater from lock and spillway operations. If recirculating lift water reduces freshwater consumption, those seaward salinities will rise. A verified numerical model of the waterways seaward of the locks can predict the rise in salinity, but this screening-level evaluation is limited to the reasonable approximation that the ratio of salinity just outside the lock to salinity just inside the lock is constant.

In the spreadsheet several parameters are highlighted in yellow to indicate that they can be changed to evaluate different procedures and assumptions for the holding pond recirculation operation. In the following, six cases are explicitly considered, as listed in Table 3-6 with the equilibrium salinity results for Pedro Miguel Lock (L3) and highest Gatun Lock (L4).

Figures 3-7 and 3-8 show the results for Case P1 for the Gatun Locks and Miraflores Locks, respectively. The Gatun Locks reach an equilibrium condition

${ }^{1}$ EXCEL spreadsheet titled "HOLDINGPOND.XLS." 


\begin{tabular}{|c|c|c|c|c|c|c|c|}
\hline \multirow[b]{2}{*}{ Case } & \multicolumn{4}{|c|}{ Parameter } & \multicolumn{3}{|c|}{ Results $^{1}$} \\
\hline & $\begin{array}{l}\text { Initial Holding } \\
\text { Pond Salinity } \\
\text { ppt }\end{array}$ & $\begin{array}{l}\text { Fraction of } \\
\text { Lift Water } \\
\text { from Pond, \% }\end{array}$ & $\begin{array}{l}\text { Ratio of } \\
\text { Volume of } \\
\text { Upper Holding } \\
\text { Pond, } V_{U H P} / V_{L} \\
\end{array}$ & $\begin{array}{l}\text { Limiting } \\
\text { Salinity in } \\
\text { Highest } \\
\text { Lock, ppt } \\
\end{array}$ & $\begin{array}{l}\text { L3 } \\
\text { Equilibrium } \\
\text { Salinity } \\
\text { ppt }\end{array}$ & $\begin{array}{l}\text { L4 } \\
\text { Equilibrium } \\
\text { Salinity } \\
\text { ppt }\end{array}$ & $\begin{array}{l}\text { Fresh Water } \\
\text { Usage } \\
\% \text { of normal }\end{array}$ \\
\hline Base & -- & 0 & -- & -- & 0.09 & 0.1 & 100 \\
\hline $\mathrm{P} 1$ & 0 & 100 & 2 & 0 & 0.28 & 1.3 & 40 \\
\hline P2 & 0 & 50 & 2 & 0 & 0.16 & 0.8 & 70 \\
\hline P3 & 0 & 100 & 4 & 0 & 0.22 & 1.3 & 40 \\
\hline P4 & 0 & 100 & 2 & 0.3 & 0.16 & 0.3 & 60 \\
\hline $\mathrm{P5}$ & 8 & 100 & 2 & 0.3 & 0.22 & 0.3 & 40 \\
\hline P6 & 4 & 50 & 2 & 0.3 & 0.16 & 0.3 & 70 \\
\hline
\end{tabular}

after about 80 lockages, with the holding ponds reaching a salinity of about $10 \mathrm{ppt}$ and L4 reaching $1.3 \mathrm{ppt}$. Despite an initial increase in freshwater consumption due to filling the ponds, Case P1 reduces long term consumption substantially, to about 40 percent of that used by the normal method. This amounts to one lift volume of 0.1 million cu m (3.6 million $\mathrm{ctt}$ ) per lockage once the initial two lift volumes used to fill the pond are saved. L3 salinity does not rise as high as L4 in the Gatun Locks, since the volume of Miraflores Lake buffers the salinity increase in L3 (at the cost of increasing salinity in Miraflores Lake), and it is not at equilibrium after 100 lockages. Extension of the calculations to 600 lockages (the number shown to be needed for equilibrium by the zero-order model) shows L3 to reach a maximum of about $0.28 \mathrm{ppt}$ for case P1.

Cases P4-P6 add a maximum salinity criterion to the holding pond procedure to reduce salinity intrusion to Gatun Lake, in that once the salinity in the uppermost lock exceeds a preset limit, both holding ponds are flushed and refilled with fresh water. The criterion is expressed as a limiting salinity as shown in column 5 of Table 3-6. Figure 3-9 illustrates the salinity responses of L4 for a limiting salinity of $0.3 \mathrm{ppt}$. Once the salinity limit is reached at about 12 lockages it cycles more often as the seaward limit salinity rises, requiring refilling the ponds after 7 cycles the second time and with increasing frequency until they must be flushed and refilled every 3 lockages at 100 lockages. Despite this increased frequency, the method is seen to still conserve fresh water, reducing consumption by about 40 percent. 


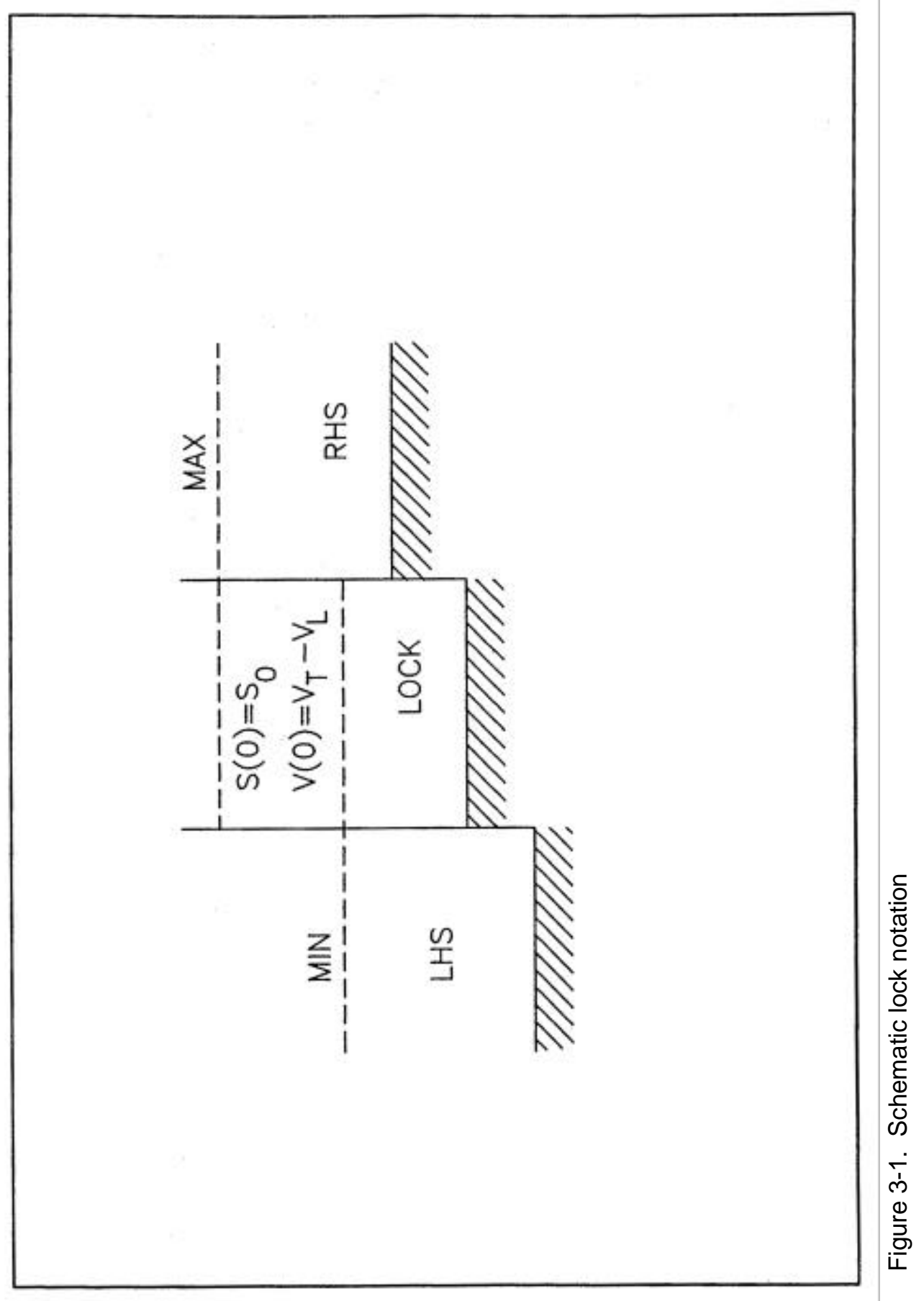




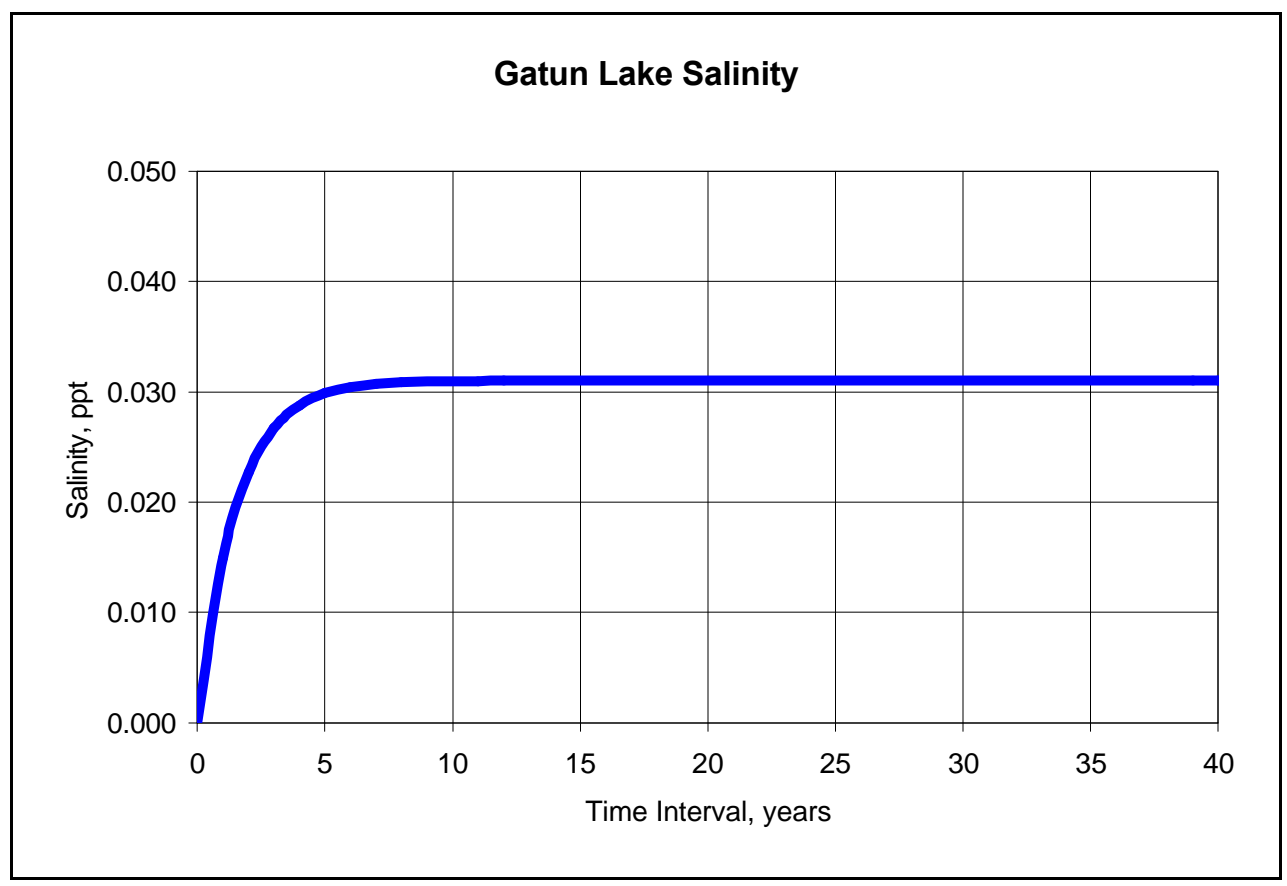

Figure 3-2. Case 1: Gatun Lake Salinity, 38 locks/day on conventional locks, no lockages/day on Syncrolift Locks, lock exchange ratio of 50 percent, salinity of $0.100 \mathrm{ppt}$ in conventional locks and $0.0 \mathrm{ppt}$ in Syncrolift Lock

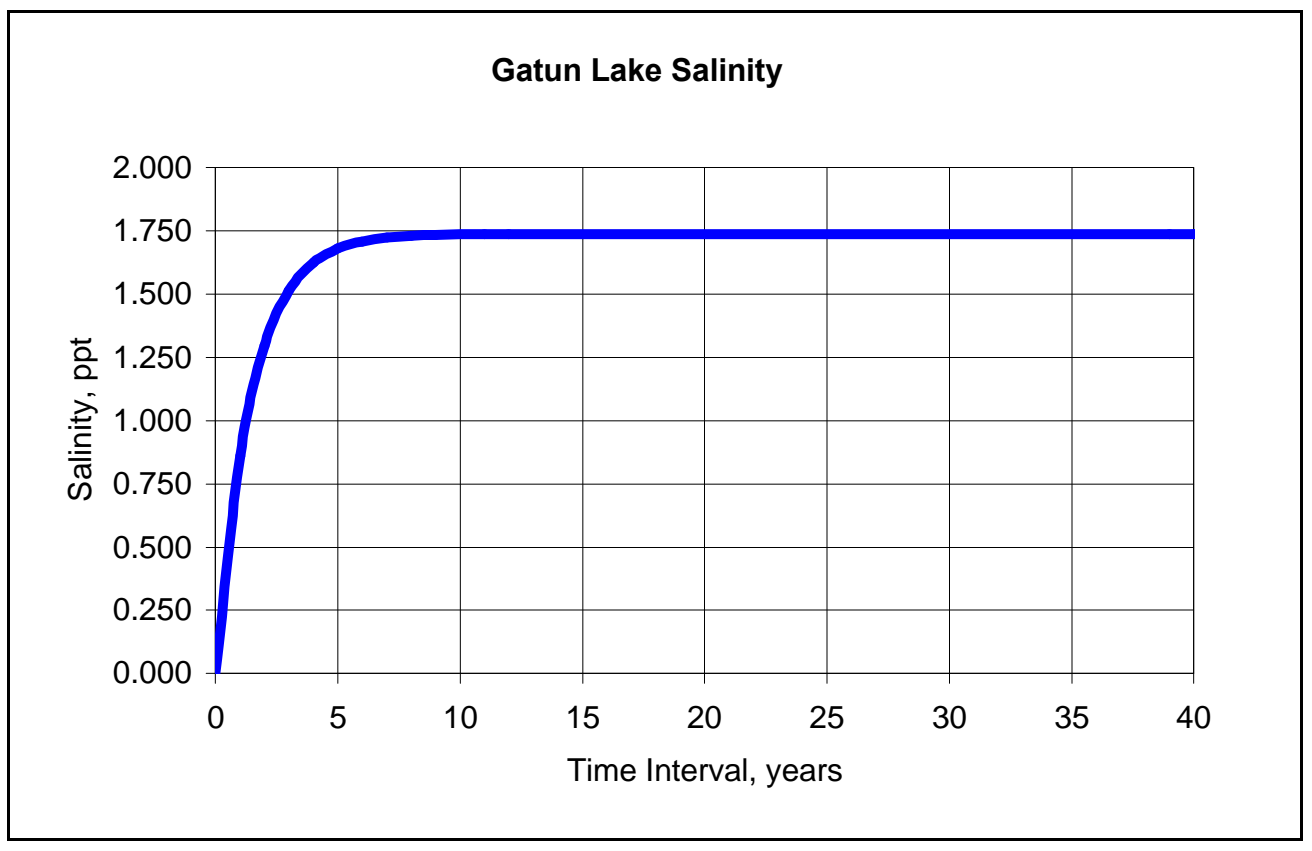

Figure 3-3. Case 2: Gatun Lake Salinity, 38 locks/day on conventional locks, 20 lockages/day on Syncrolift Locks, lock exchange ratio of 50 percent, salinity of $0.100 \mathrm{ppt}$ in conventional locks and $35.0 \mathrm{ppt}$ in Syncrolift Lock 


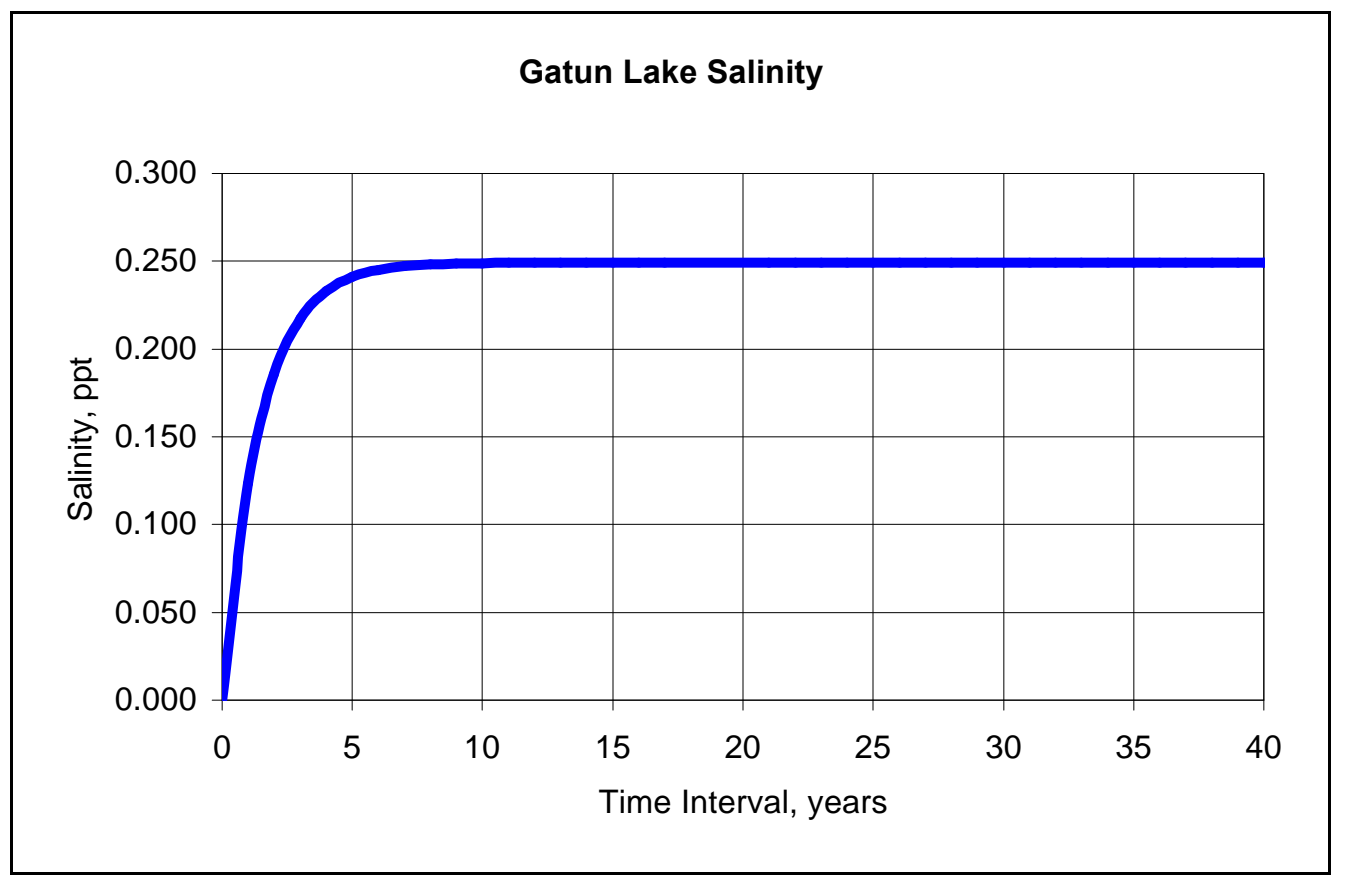

Figure 3-4. Case 3: Gatun Lake Salinity, 38 locks/day on conventional locks, 20 lockages/day on Syncrolift Locks, lock exchange ratio of 50 percent, salinity of $0.100 \mathrm{ppt}$ in conventional locks and $4.5 \mathrm{ppt}$ in Syncrolift Lock

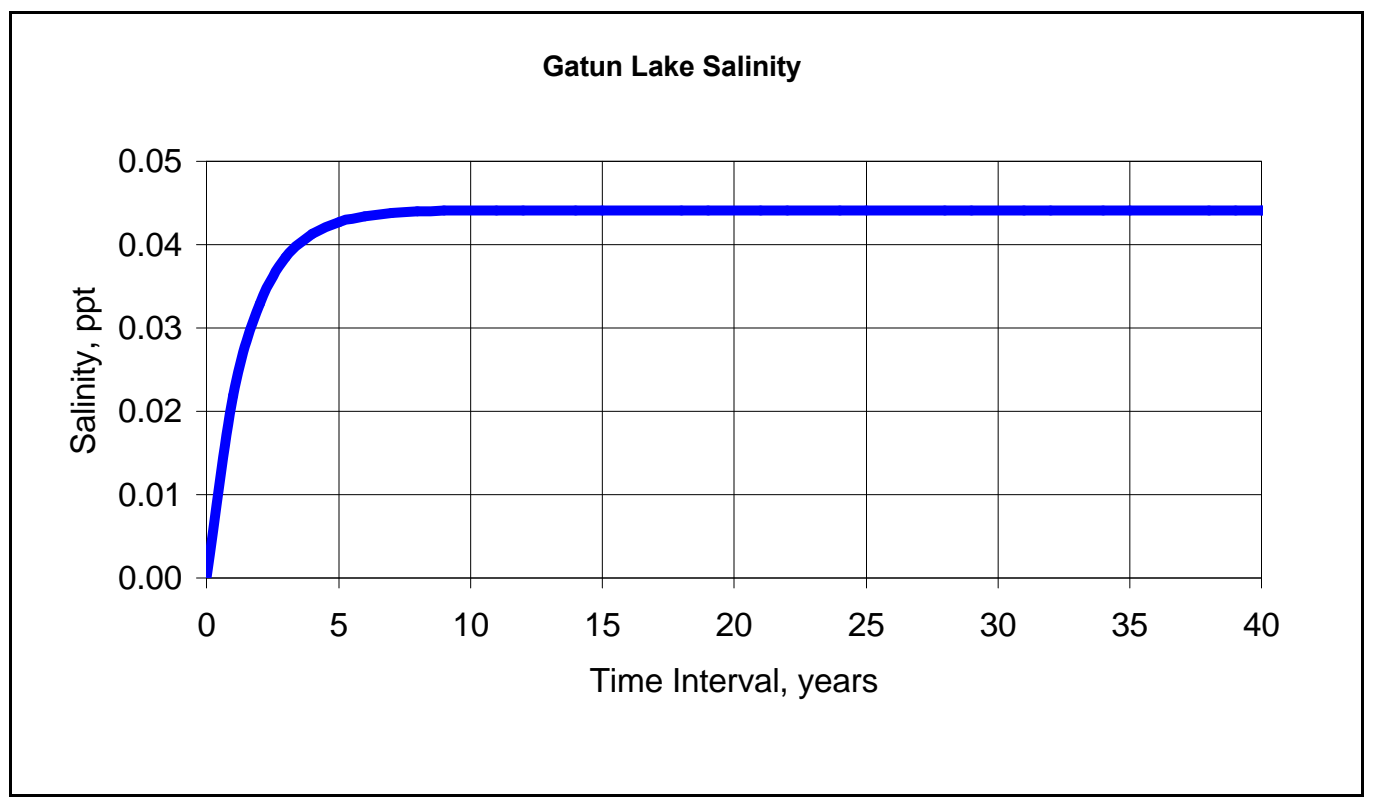

Figure 3-5. Case 4: Gatun Lake Salinity, 38 locks/day on conventional locks, 20 lockages/day on Syncrolift Locks, lock exchange ratio of 50 percent, salinity of $0.100 \mathrm{ppt}$ in conventional locks and $0.300 \mathrm{ppt}$ in Syncrolift Lock 


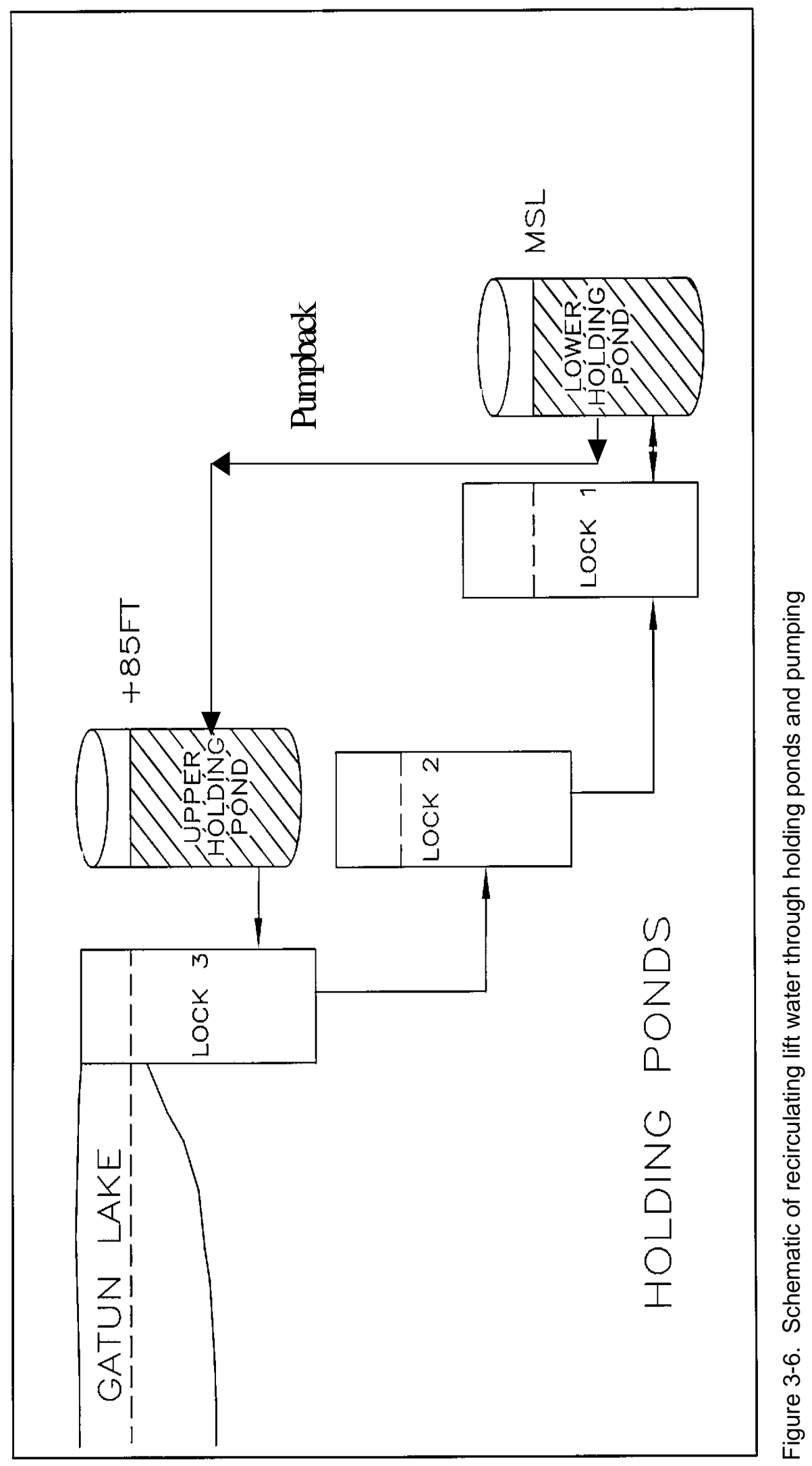



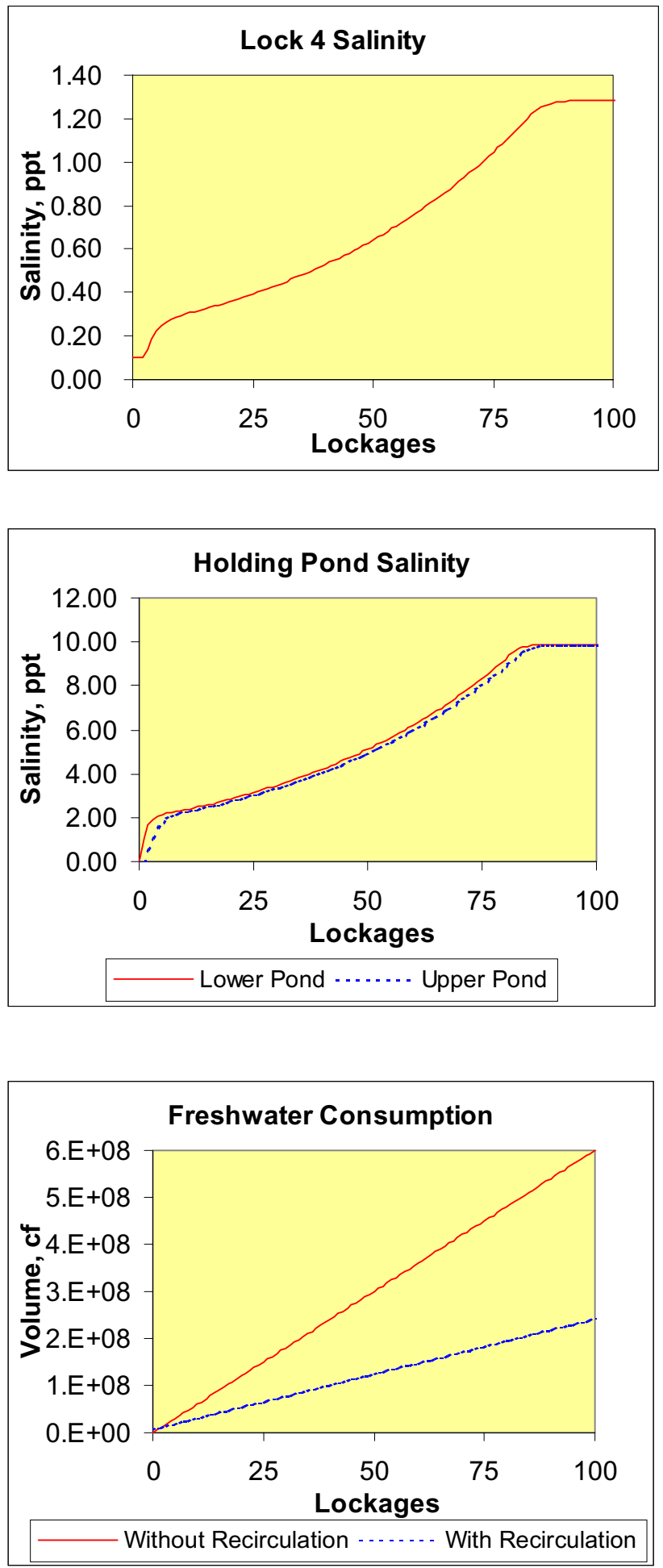

Figure 3-7. Gatun Locks salinities and freshwater consumption with holding pond recirculation for Case 1: ponds holding two lift volumes with initial salinity of $0 \mathrm{ppt} ; 100$ percent of lift volume from holding pond 

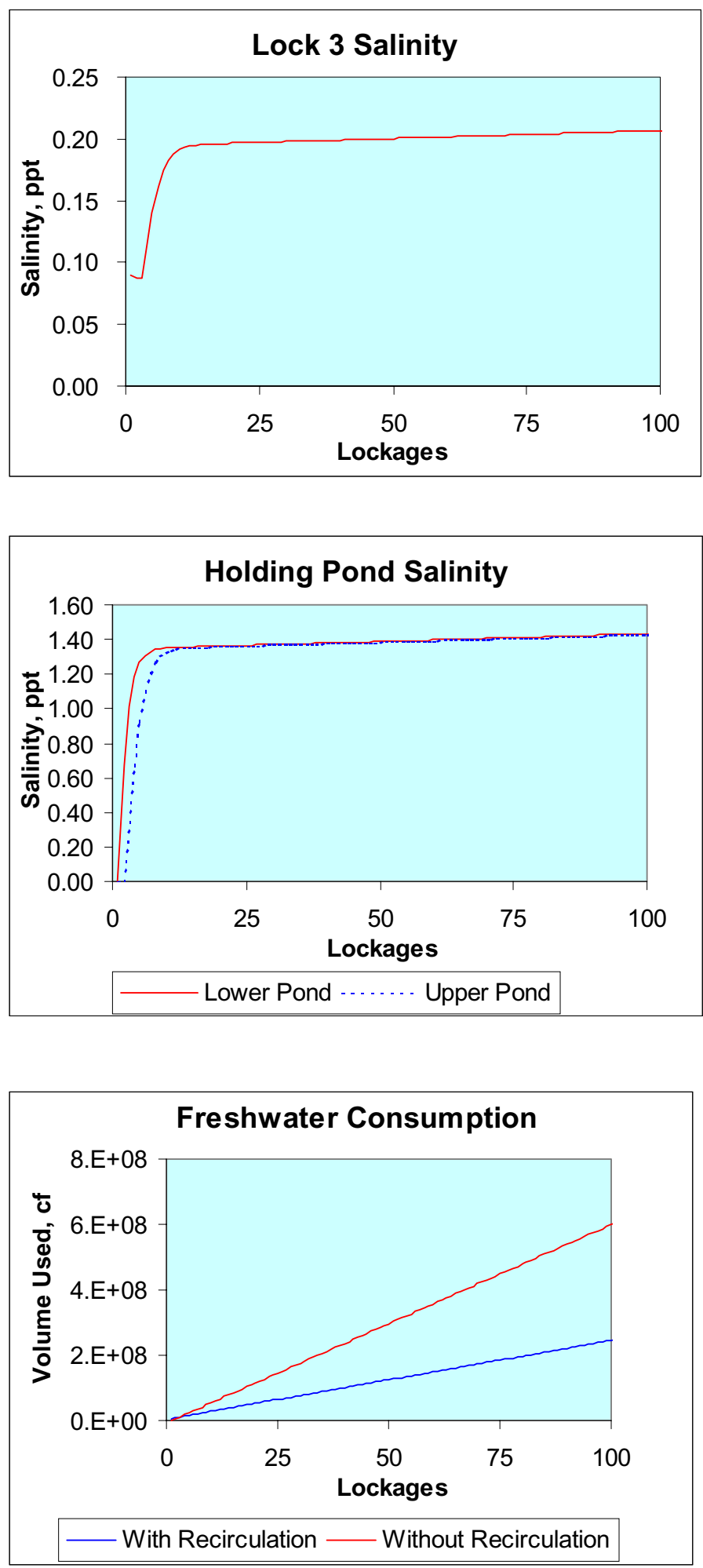

Figure 3-8. Miraflores Locks salinities and freshwater consumption with holding pond recirculation for Case 1: ponds holding two lift volumes with initial salinity of $0 \mathrm{ppt} ; 100$ percent of lift volume from holding pond 

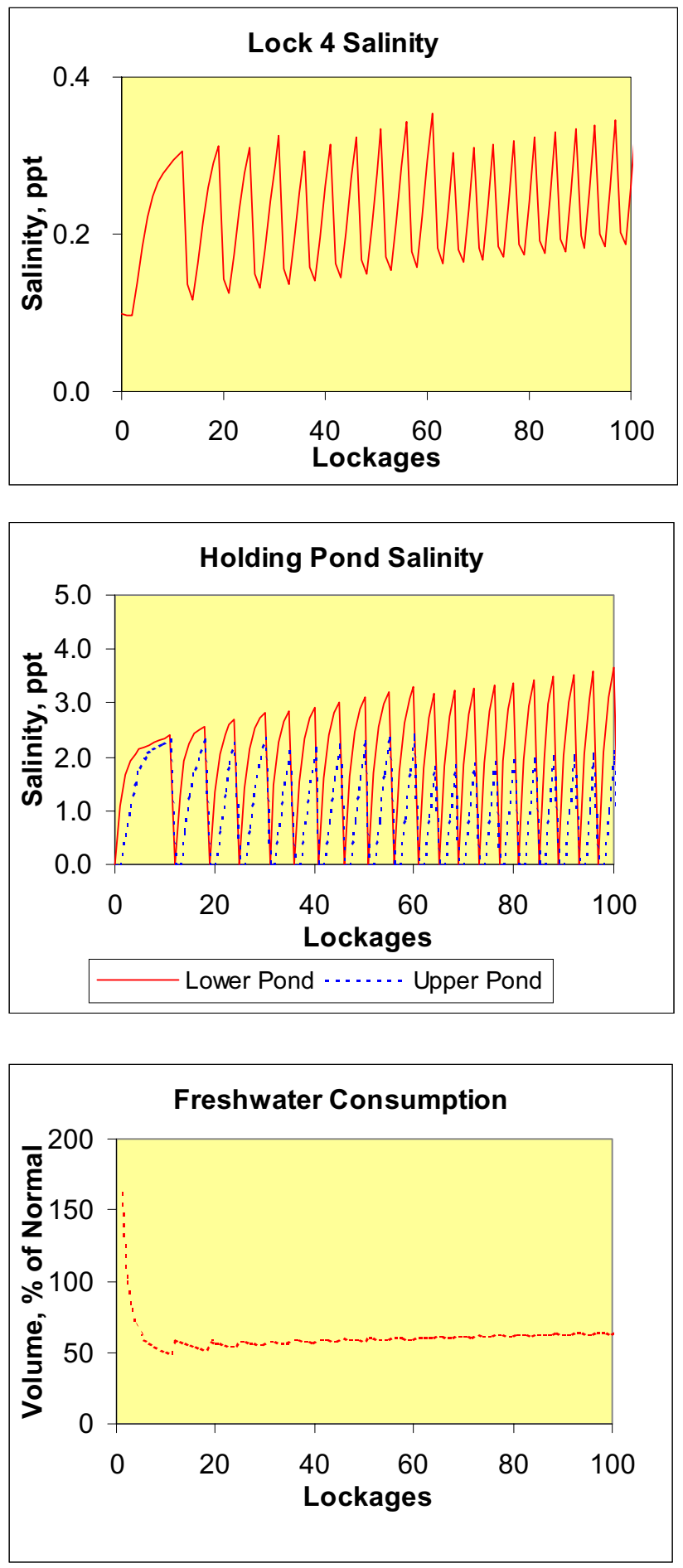

Figure 3-9. Gatun Locks salinities and freshwater consumption with holding pond recirculation for Case P4: ponds holding two lift volumes with initial salinity of $0 \mathrm{ppt} ; 100$ percent of lift volume from holding pond, and limiting salinity of $0.3 \mathrm{ppt}$ 


\section{Methods of Reducing Saltwater Intrusion in Navigation Locks}

A review of the literature was performed to identify methods which have been shown to successfully reduce salt water intrusion through navigation locks. Methods and designs from the United States, the Netherlands, France, and China are briefly described here. This section draws on the published literature, Appendices B and C, and an unpublished review by the Panama Canal Commission (Kiamco 1999).

\section{Survey of Methods}

\section{Flushing canal with fresh water}

A repressive method of combating salinity intrusion through locks is to flush the "collector" canal with fresh water in the direction of the sea. However, this method is not very effective when used alone. The difference in density allows a comparatively large volume of salt water to enter the canal through the lock and a comparatively large volume of fresh water would be required to mix with it and carry it away. Tests have shown that the dimensions of canals very greatly affect the degree of salt intrusion. A small increase in depth causes a comparatively large rise in the salinity of the water in a canal.

\section{Pneumatic barriers}

Pneumatic barriers are curtains of air bubbles rising from perforated pipes placed on the bottom of a channel or lock chamber perpendicular to the axis of the channel (See Figure 4-1). The rising bubbles create a vertical current of water, which reduces the magnitude of any exchange currents passing over it, provided the volume of air is adequate. The mechanics of flow and mixing near a pneumatic barrier are described by McAnally (1973).

Pneumatic barriers reduce salt intrusion that is caused by density exchange currents. This is important, as salt intrusion is largely due to density exchange 
currents. The efficiency of pneumatic barriers in reducing exchange currents during locking operations has been studied extensively in the laboratory and the field. Field studies were conducted in the Ijmuiden locks, the Netherlands. Salinity intrusion can be reduced by 50 to 80 percent depending upon the amount of air used. The efficiency decreases with increasing water depth in the locks. Experience shows that the pneumatic barriers can be expensive to operate and need careful operation and maintenance. Further, since they induce intense mixing, their use precludes capture techniques such as selective withdrawal once mixing has begun.

\section{Water barriers}

Theoretically, a vertical current like that produced by a pneumatic barrier can also be induced by pumping water, thus creating a water barrier, which would also reduce the magnitude of the exchange currents. Initial experiments with this method have been carried out on models.

\section{Selective withdrawal of salt water during intrusion}

The salt water tending to enter the canal when the inner gates of a lock are opened can be withdrawn and discharged back into the sea during the exchange process through a slot in the bottom of the lock located at the point where the lock meets the adjoining fresh water basin. The volume of fresh water wasted corresponds to the quantity of water withdrawn through the slot. If withdrawal cannot be entirely selective, the amount of fresh water wasted during each complete locking cycle will exceed the volume of the lock chamber. This system has been applied at the Terneuzen-locks, the Netherlands. Salt-water intrusion is prevented at the cost of a relatively large amount of fresh water due to limitations in the selective withdrawal of salt water.

\section{Selective withdrawal of salt water after intrusion}

The intrusive salt water is collected in a sump of adequate volume made by deepening part of the canal, selectively withdrawn from it and discharged in a steady stream (see Figure 4-2). The volume of fresh water wasted corresponds to the quantity of water withdrawn from the sump. Since the salt water is diluted as it enters and while it remains in the sump, more fresh water will be wasted than when using the method described in item 4 above. A drawback of this method is that not all the intrusive salt water is trapped in the sump; some of it passes on into the canal and has to be removed by flushing. Large volumes of fresh water are required to expel even small quantities of salt water. The basin has to be large enough to avoid overtopping by salt water and to allow selective withdrawal of the salt water. This method is employed at the Chittenden Locks in Seattle Washington as described in a subsequent section. 


\section{Equalization by pumping instead of gravity}

If there is a considerable difference between average canal level and high water on the seaward side of the lock, salt intrusion can be greatly reduced by pumping the water in the lock chamber back into the sea instead of allowing it to reach the canal. Large-capacity pumps would be required to remove the large quantities of water in lock chambers in a short time. The pumping capacity required could be reduced by storing the water in a basin between the lock and the sea and artificially keeping the level in the basin lower than that in the lock chamber. This advantage of the method is that there is more time for pumping water out of the basin.

\section{Exchanging while gates are closed}

The salt water can be withdrawn from the lock chamber through orifices near the bottom and replaced by letting fresh water into the chamber through orifices near the surface of the water. Fresh water can be replaced by salt water in like manner, the salt water being admitted near the bottom and the fresh water being withdrawn near the surface. If this exchange process is completed before the gates are opened, waters of different density are prevented substantially from mixing thus obviating exchange currents. There would be a certain amount of mixing while the exchange is being effected; the vessels in the lock chamber would also cause some fresh water to be wasted due to mixing. The fresh water can be withdrawn and admitted through the wall of the chamber or through the gates at the fresh-water end.

\section{Movable sill}

One of the measures used to reduce the exchange flows is to have a movable sill, which is adjusted to the draft of the ships to be locked (see Figure 4-3). This option involves risk of mechanical damage, which may make the option ineffective or may block navigation. It is employed at the Chittenden Locks in Seattle Washington as described in a subsequent section.

\section{Simultaneous exchange of salt and fresh water}

Locks of this type have perforated false floors to evacuate or to introduce salt water and have openings in the side walls for the exchange of fresh water while the lock gates are close. The system has been applied in the Mardyck sluice at Dunkirk with dimensions of 145 x 12 x 4 m (Ribes and Blanchet, 1965, Monadier, 1981) and the Kreekrak sluices, the Netherlands, with dimensions of 330 × 24 x 6 m (Kolkman and Slagter, 1976). The saltwater intrusion can be reduced to about 5 percent of the lock chamber volume with a freshwater loss of about 60 percent of the lock volume. 


\section{Canal gate}

Another option for the lakeside canal is to have two or more deeper basins and a gate at the freshwater end, so that the length of the canal is available for temporarily trapping salt water. By itself, such a design will offer few significant advantages, but in combination with other measures it can be used to retain brackish water until such time as flushing can be accomplished. For example, if a movable sill and selective withdrawal were used, but sometimes failed to capture all the salt water, a long canal with sills at intervals would trap the excess salt water for an extended period, then it could be flushed (item 1) when an ample supple of freshwater became available

\section{New developments}

Various new lock types have been designed and tested to reduce freshwater losses (Van der Kuur, 1985, Kolkman, 1986, and NN, 1986). An example is the lift lock, which has an inner lock chamber which moves vertically. The outer lock chamber is twice as deep as normal. The inner lock chamber is always filled with salt water. Other lock types have been studied, such as locks with artificial reed screens to decrease exchange flows and locks with horizontal flexible membranes to prevent mixing between salt and fresh water (van der Kuur, 1985). Freshwater losses with this type of lock are reduced to about 5 percent of the lock chamber volume, whereas saltwater intrusion is only about 5 percent of the lock volume.

\section{Selecting The Method}

\section{For existing locks}

A method that might be considered for canals linked with existing locks is to flush them daily with copious quantities of fresh water. The quantity of water required to flush wide, deep canals is considerable; it would not always be possible to satisfy the maximum permissible salinity requirements in certain places. If flushing does not produce the desired result, a stretch of canal close to the lock could be deepened and used as a sump in which the salt water would collect. A pumping station operating with a deep suction nozzle would withdraw the salt water and pump it into the sea. If necessary, a wall could be built between the pumping station and the sump with orifices near the bottom of the latter. Alternatively, the salt water could be removed by gravity if the water level in the canal were either temporarily or permanently higher than that of the sea.

The quantity of salt water intruding into an existing canal owing to exchange flow caused by differences in density can be reduced by means of an air-bubble curtain placed near the lock gates. This option could be combined with the sump method described above or with an adjustable barrier. Whether a single method or a combination of methods is adopted depends on their local feasibility. 


\section{For projected locks}

Installing water curtain equipment in existing locks is difficult because of the size of the pipes required. It is even questionable whether this method would be so much better than the other options as to warrant its adoption for new locks. The qualitative control of fresh water constantly has to be stepped up and it is essential to be economical with fresh water for many reasons.

There are four methods is addition to the three already described for existing locks that may be considered for new locks, viz.

a. Construction of a sump next to the lock on the landward side from which the intrusive salt water can be selectively withdrawn

b. Replace salt water in the lock chamber by fresh water while the lock gates are closed

c. Pump the water required for equalization into the sea.

d. Adjustable barrier

\section{Navigation Locks in the Netherlands}

The most important 15 navigation locks in the Netherlands and the methods employed in them for salinity intrusion control are described below. The main features of options are:

a. The flushing method is used for all locks; water from the canal is flushed through openings placed as low as possible in the lock or sluice structures.

$b$. The velocity of the current passing through the openings may exceed a certain magnitude to ensure that the water discharged will contain the maximum amount of salt.

c. Since the salt water pumped from the polders in various places as well as that coming in through the locks reaches the canals, the fresh water flowing towards the locks also helps to overcome the salinization of the country's water and soil.

d. It should be noted that it would always be necessary to flush the systems with a certain quantity of fresh water, no matter how effective any steps taken to reduce the waste of fresh water through locks may be.

e. Air curtain equipment has already been installed in a number of locks and others are to be equipped with the system in the near future.

f. Supplementary systems are being considered for certain locks. 
g. One or more locks at seven sites in the Netherlands are equipped with pneumatic barriers, viz. at Harlingen, Den Helder, Ijmuiden, Hartel canal/Brielse Meer, Haringvliet, Volkerak and Terneuzen.

Abraham et al. (1973) have provided a brief description of salinity intrusion control measures at several docks in the Netherlands. A section of that report is reproduced verbatim below.

\section{Delfzijl}

Salinization of the canals running from the locks is countered by replacing the water in the canals at regular intervals by rainwater and by water drawn from Lake IJssel. The locks are provided with apertures located well below the water line so as to make the replacement process as effective as possible.

\section{Lauwerszee}

Damming off the Lauwerszee has very greatly reduced the salinity of the adjoining parts of the provinces of Friesland and Groningen. Sluices are incorporated in the dam through which excess water may be discharged. Provision has been made for the comparatively small lock to be fitted with aircurtain equipment, if required.

\section{Harlingen}

Salt intrusion through the locks is countered by replacing the water in the canals at regular intervals by rainwater and by water drawn from Lake IJssel. Air-curtain equipment is also used to further reduce salinization.

\section{Zuyder Zee Barrier Dam}

There are locks in the dam beside the two sets of sluices with which the water in Lake IJssel is controlled. Arrangements are being made to equip all the locks with pneumatic barriers.

\section{Den Helder}

Salt intrusion through the three locks and the sea dock lock is countered by replacing the water in the canals at regular intervals by rain water and by water drawn from Lake IJssel. Arrangements are being made to replace gravity discharge by pumping. A sump is to be built near the pumping station in which to store the salt water from the locks prior to its being pumped into the sea. The most important lock is equipped with a pneumatic barrier.

\section{Ijmuiden}

Salt intrusion through the North Sea Canal is countered by replacing the water at regular intervals by water from the adjoining regions and from Lake IJssel. The four locks are equipped with a pneumatic barrier. Arrangements are being made to install a pumping station to supplement gravity discharge through a sluice. The construction of a deep sump to collect the salt water is also being 
contemplated together with a salt baffle to maximize the salinity of the water discharge into the sea.

\section{New Waterway- New Maas}

There are a number of locks along the New Waterways and the New Maas, both of which are open to the sea. Salt intrusion in the canals running from the locks is countered by replacing the water by rain water and water drawn from the River Rhine. The quantity of river water required could be somewhat reduced by installing pneumatic barriers in the locks but there are as yet no plans to make any such provisions.

\section{Hartel Canal and Brielse Meer}

The Hartel canal is the landward shipping link between Europoort and the Old Maas. There are pneumatic barriers in the two locks that give access to the Old Maas to reduce salinization of the latter. The canal is also flushed with river water, which runs out through the locks, which are also equipped with pneumatic barriers.

The Brielse Meer is a fresh-water lake south of the Hartel canal; a lock links it with the Old Maas. The lake must be protected as well as possible against salinization if the salt intrudes beyond the lock when Rhine is low. Consequently, a great deal has been done to counter salt intrusion at this point. There are two pumps in two culverts by means of which water can be pumped out of the lock chamber. There is air-curtain equipment and a deep sump in the canal next to the lock to which the pumps can be connected to remove any salt water that may get through the lock.

\section{Haringvliet}

The Haringvliet lock is fitted with pneumatic barriers. There are deep culverts in the sluice next to the lock connected with a sump from which any salt water can be withdrawn.

\section{Volkerak}

There are two locks linking the rivers with Zeeuwse Meer. The water south of the dam will be strongly saline until the Eastern Schldt dam is finally closed in 1978; meanwhile, salt intrusion through the locks is being reduced by means of pneumatic barriers.

\section{Canal Across Walcheren}

Salt intrusion through the locks at flushing was investigated by conducting model experiments to discover whether a canal flushing system would be effective or whether the locks will have to be equipped with pneumatic barriers at both ends. 


\section{Canal Across South Beveland}

A modern system of countering salt intrusion is being considered; the salt water in the lock chambers would be replaced by fresh before opening the gates giving access to the fresh-water lake. The fresh water used would serve to clean the adjoining canal.

\section{Scheldt-Rhine Canal}

Two locks are being incorporated in the canal linking Antwerp with the Rhine. Salt intrusion will be countered by replacing the salt water in the lock chambers by fresh water flowing in through apertures in the walls while the gates are closed. As in the new system described in 13, the fresh water used would serve to clean the adjoining stretch of the fresh-water lake.

\section{Terneuzen}

There is one old and two new locks in the canal between Terneuzen and Gent. Pneumatic barriers reduce salt intrusion through the new inlandwaterways lock. A sump has been constructed next to the new sea lock with deep culverts the orifices of which are built into the lock to carry the salt water trapped in the basin towards the sea. The level of the water in the canal is almost always above that of the high tides, so discharge is by gravity. Moreover, salt intrusion is further reduced by means of pneumatic barriers.

\section{Kreekrak}

The Kreekark lock in the Netherlands has dimensions of $320 \times 24 \times 5 \mathrm{~m}$. The lock is used in achieving a water level change of 1.3 to $2.3 \mathrm{~m}$. It is navigable for 4-barge push-tows of 11,000 metric tons (10,000 tons), with the design annual traffic capacity of 66 million metric tons (60 million tons). Fresh water reservoirs are provided on both sides of the chamber. A salt-water reservoir with a size of 40 hectares is also provided. The area of the salt-water reservoir is 26 times that of the chamber. The lock is operational since 1986 and is functioning well. The Kreekrak lock is an improved version of Mardyck lock in France. It also uses a complete exchange system; however, the fresh water loss is reduced to about 15 to 30 percent. The reasons for improved performance are: a) open fresh water channel used instead of long culverts, b) lift gate is provided at the immediate outlet of culverts, which can be adjusted according to tidal level changes, thus preventing salt water intrusion, and c) the bottom slab is channel shaped and water being discharged through outlets on the sides of channel eliminate vertical currents, which produce salt and fresh water mixing.

\section{Philip}

The Philip lock has dimensions of $280 \times 24 \times 5 \mathrm{~m}$ and is navigable for 4barge pushtow of 11,000 metric tons (10,000 tons). The lock is subjected to twoway water head and water level difference of $1.7 \mathrm{~m}$. Philip lock made the following improvements over the Kreekrak lock: 1) Since outlets in channeled bottom are located at the middle of the channel sides, water below outlets cannot drain well, so bottom slabs of T and inverted T shapes are used. 2) Weir gates at 
the freshwater outlets are not closed to the top; thus the freshwater between the operating valves and the weir gate will get salted with a loss of 5\%.3) When salt water surface travels towards the bottom during exchange, there will be vertical currents in culverts at the bottom of salt-water body causing greater flushing. 4) When the chamber is full of fresh water and a ship enters, the water levels in the front and back of the ship are different. This provides opportunity for salt water to enter the chamber and fresh water to enter culverts.

\section{Hiram Chittenden Locks, Seattle WA, USA}

Salt water intrusion problems in USA are predominantly related to estuaries and inland navigation. A summary note on these problems is given in Appendix B. Other problems have been related to salt water intrusion at dams. The primary U. S. location where salt intrusion through locks has been addressed is the Hiram Chittenden Locks on the Lake Washington Ship Canal, Seattle, WA.

Construction of these locks was accomplished during 1911-1917 to provide access to and from the salt water regime of Puget Sound and the fresh water lakes of Lake Union and Lake Washington in the state of Washington, USA. The intrusion of salt water into the fresh water regime is controlled through a number of operational and structural methods. Foremost are the salt water scavenging drain, maintaining salt water barrier in the upright position, and use of a small lock to prevent salt water intrusion into Lake Washington. During critical years, the potential for intrusion becomes an intensified coordination process of water / lock usage with municipal water supply authorities, environmental agencies and the general public on operational uses of fresh water at the lock structures. Appendix $\mathrm{C}$ describes the design and operations employed at the Chittenden Locks.

\section{Navigation Locks in China}

The Haihe lock in China has made the following improvements.

a. In view of limited land area available, the design rejected the fresh water reservoir option. Instead, a fresh water culvert plan is adopted.

$b$. The lock design adopts grade crossing of four-way culverts with a control valve on each of the culverts at the cross.

c. The available land allows to build a reservoir only 5 times that of the lock chamber area. Hence a pump station with a capacity of 20 cubic meters per second has been provided.

d. The lock has less flow dividing piers.

$e$. Froude number of about 1.0 is achieved at the point of water exchange at the outlets. 


\section{Navigation Locks in France}

The Mardyck lock at Dunkirk Harbor in France uses a complete exchange system. The lock dimensions are $148.6 \times 12.0 \times 4.0 \mathrm{~m}$ and water level difference is about $2.0 \mathrm{~m}$. It is navigable for push tows of 3,000-ton barges and its complete water exchange requires 12 minutes. Since the lock's salt prevention measure is a combination of water exchange and salt-water trough, fresh water losses may be as high as 55 percent. The lock has been running well over its 30 years of operation.

\section{Salinity Intrusion Problems in Norway}

The problems in Norway are related to strong currents and ice formation at surface. Use of air bubbles is found to be effective in breaking down density stratification.

The Norwegian coast is basically relatively steep, with high mountains surrounding long and deep fjords, with a brackish layer on the top. Therefore, the saltwater intrusion problem as experienced in other countries like the Netherlands, or England, is not so common in Norway. In the southeastern part of the country, mainly in the Glomma estuary area, we find saltwater intrusion problems which are somewhat similar to what is typically found abroad. In the rest of the country, saltwater intrusion problems are of a different kind. Two types of problems have been experienced in Norway which can be related to navigation problems as well. Both problems are connected to the presence of saltwater intrusion in estuary or fjord areas.

The first problem is related to the outflow of fresh or brackish water through a narrow entrance. The presence of the saltier water masses below creates a strong density stratification which, in turn, creates a strong concentration of surface currents in the upper water masses. Since the area under consideration is used as a fishing harbour as well, these strong surface currents have created some navigation problems for the fishing vessels moving in and out of the harbour area. In particular, the maneuvering conditions can be difficult when incoming waves from the open sea are entering the harbour area and then meet the opposing brackish layer flow, causing the waves to steepen considerably.

The other case is of a somewhat different kind. In the winter time and under calm weather conditions, the fresh water from the river mouth will spread out in the surface layers in the fjord area. Due to the stable density stratification caused by the saline water below, the surface layer will be exposed to cooling and subsequent ice formation. The saline water stratifications will in this case act as a preventor for transport of excess heat from below. This ice might, in turn, cause difficulties for navigation to and from harbours in the area.

In the latter case, the problem was solved by means of an air-bubble plant installed in the river mouth area. In order to break down the stable density stratification, the intrusive salt water in the river mouth area was forced by the air bubble plant to mix with the fresh water. 


\section{Syncrolift Lock}

The Syncrolift Lock described in Part 2 as being considered for installation in the Panama Canal presents a somewhat different challenge for preventing salt water intrusion. Since the lock is filled to the same level at all times, water within it is not diluted by the addition of fresh lift water.

During discussions of the Syncrolift lock numerical experiments presented in Part 5 of this report, the PCC-COE design team formulated a conceptual design for preventing salinity intrusion. Depicted in Figure 4-4, it consists of a small gated antechamber at the upper lock position in the dam, separated from the lake by a movable gate. After the lock is lifted into position at the top and seated against the dam, the lock gates are opened so that saline water in the lock and fresh water in the antechamber begin to mix. Salty water is then withdrawn from the bottom of the antechamber as freshwater is released at the surface at the same flow rate. These flows are continued until the lock water is freshened to the required degree, and then the antechamber gates are opened to permit the ship to move into the lake. This concept is modeled in Part 5 of this report.

\section{Summary and Conclusions}

a. All over the world salt intrusion through navigation locks connected to ocean is being increasingly regarded as a serious threat to the quality of water in the canals that link ocean with the locks.

$b$. There are several ways of preventing salt-water intrusion in the navigation locks. The selection of method is based on factors such as site conditions, cost, volume and frequency of ship traffic etc.

c. The most effective and at the same time most expensive method is exchanging fresh water for salt water within the lock while gates are closed; however, it can also lead to adverse motion of vessels within the lock.

$d$. The option of equalizing levels by pumping instead of gravity, which only concerns the salt water required for equalization, is not very effective.

e. The selective withdrawal of salt water usually calls for substantial alterations or additions to locks and may require fairly large quantities of fresh water.

f. The water barrier method has not been tested thoroughly but should perform about the same as the pneumatic barrier.

g. Pneumatic barriers constitute a simple method of countering salt intrusion. This method will not keep all the salt out but may reduce intrusion quite considerably. Pneumatic barriers have been successfully 
installed at several locks and can be combined with other systems. The pneumatic barrier method of preventing salt intrusion is found to be suitable for practically all the locks adjoining the sea in the Netherlands. Pneumatic barriers are already operating in 13 locks.

$h$. Establishing a canal on the upstream side of the lock and flushing the canal with fresh water is less effective than the other methods and involve wasting large quantities of fresh water. It is nevertheless the oldest way of getting rid of intrusive salt. It can be retained as a useful supplement to one or more of the other methods.

$i$. For the proposed new locks, the interests served by any measures taken to combat salt intrusion are considered for each case individually.

Methods other than the pneumatic barrier system might be chosen based on certain considerations and the locks will be designed accordingly.

NOTE: See Appendix E for non-cited references used in Part 4. 


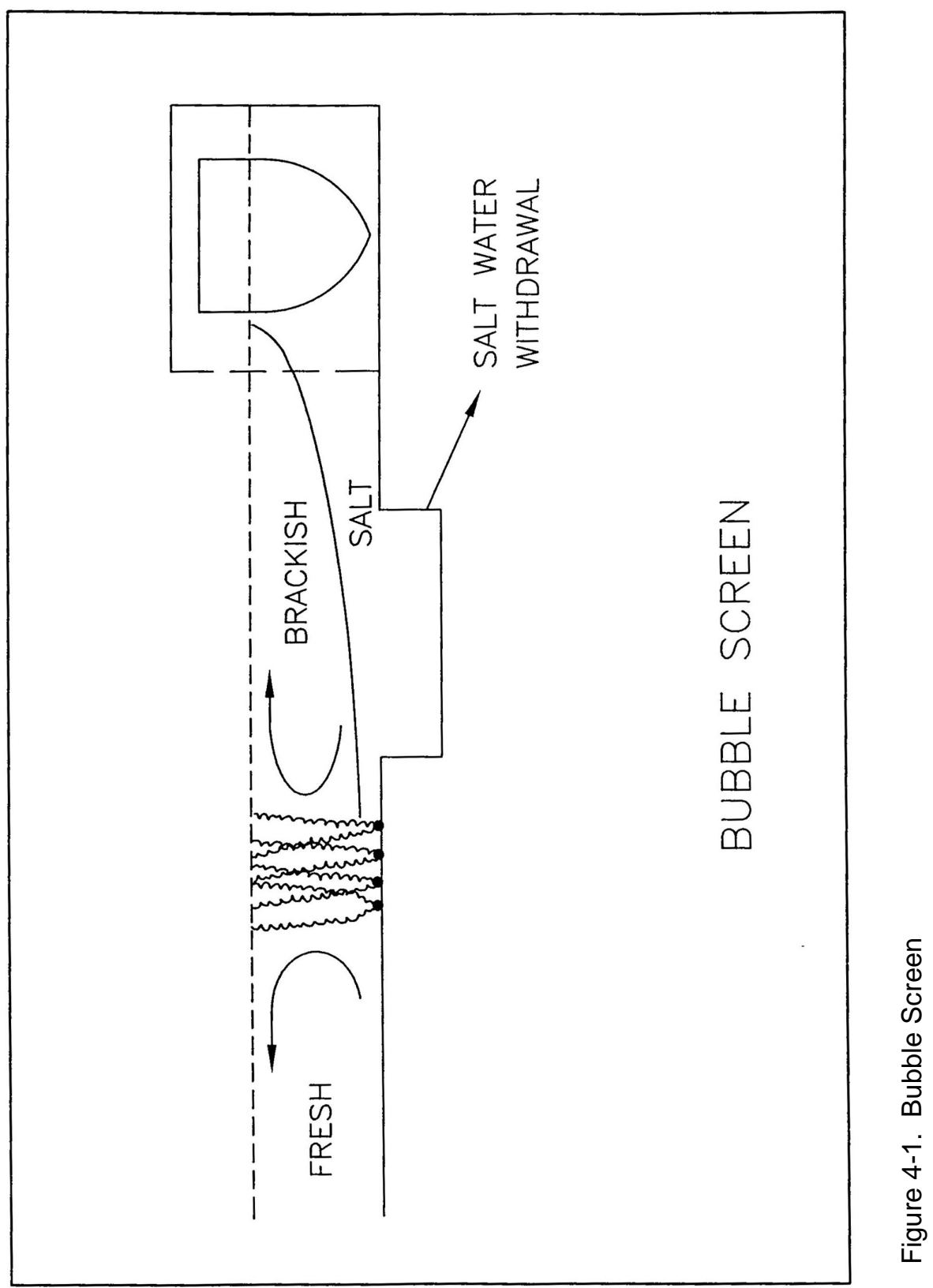




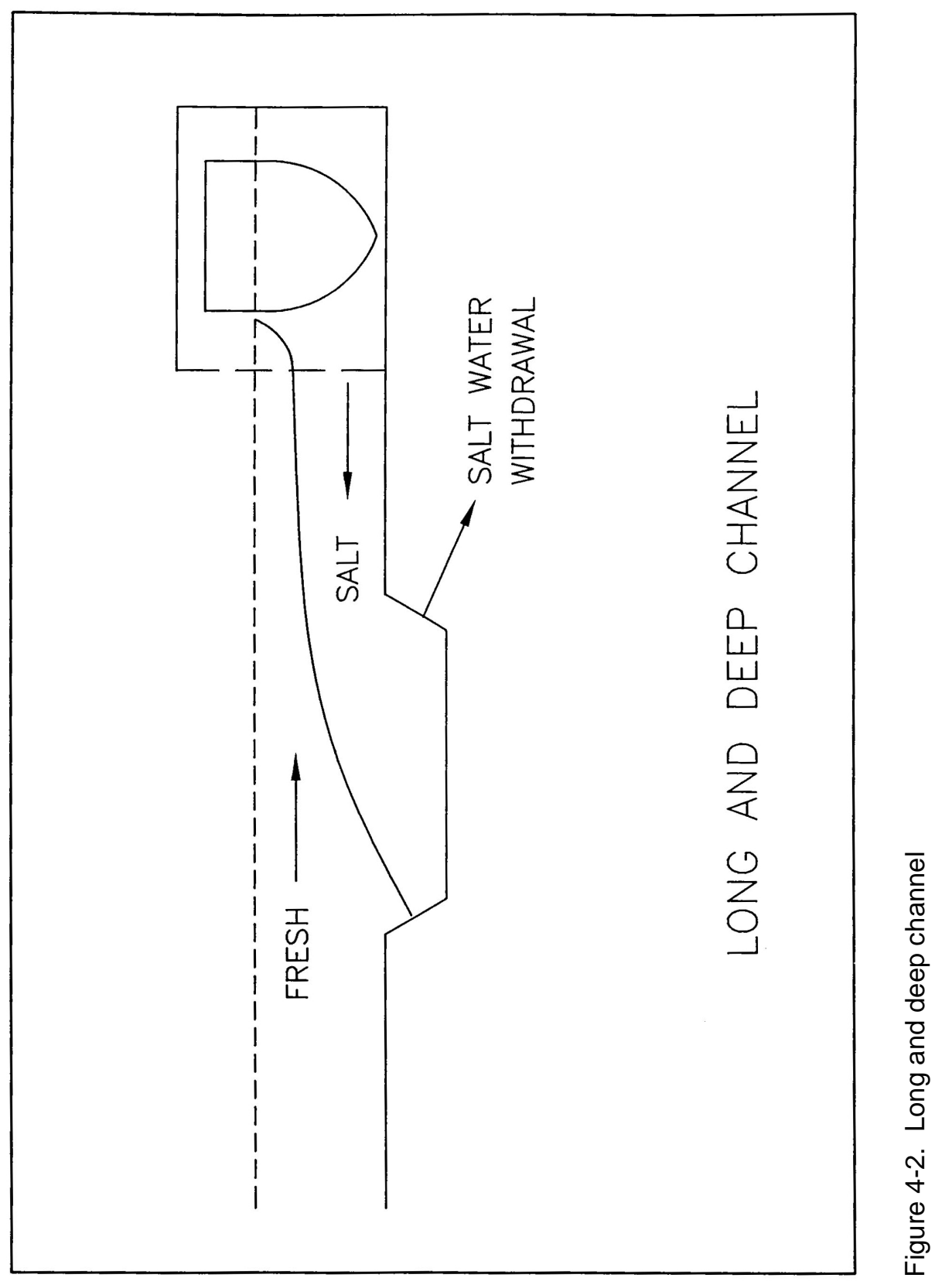




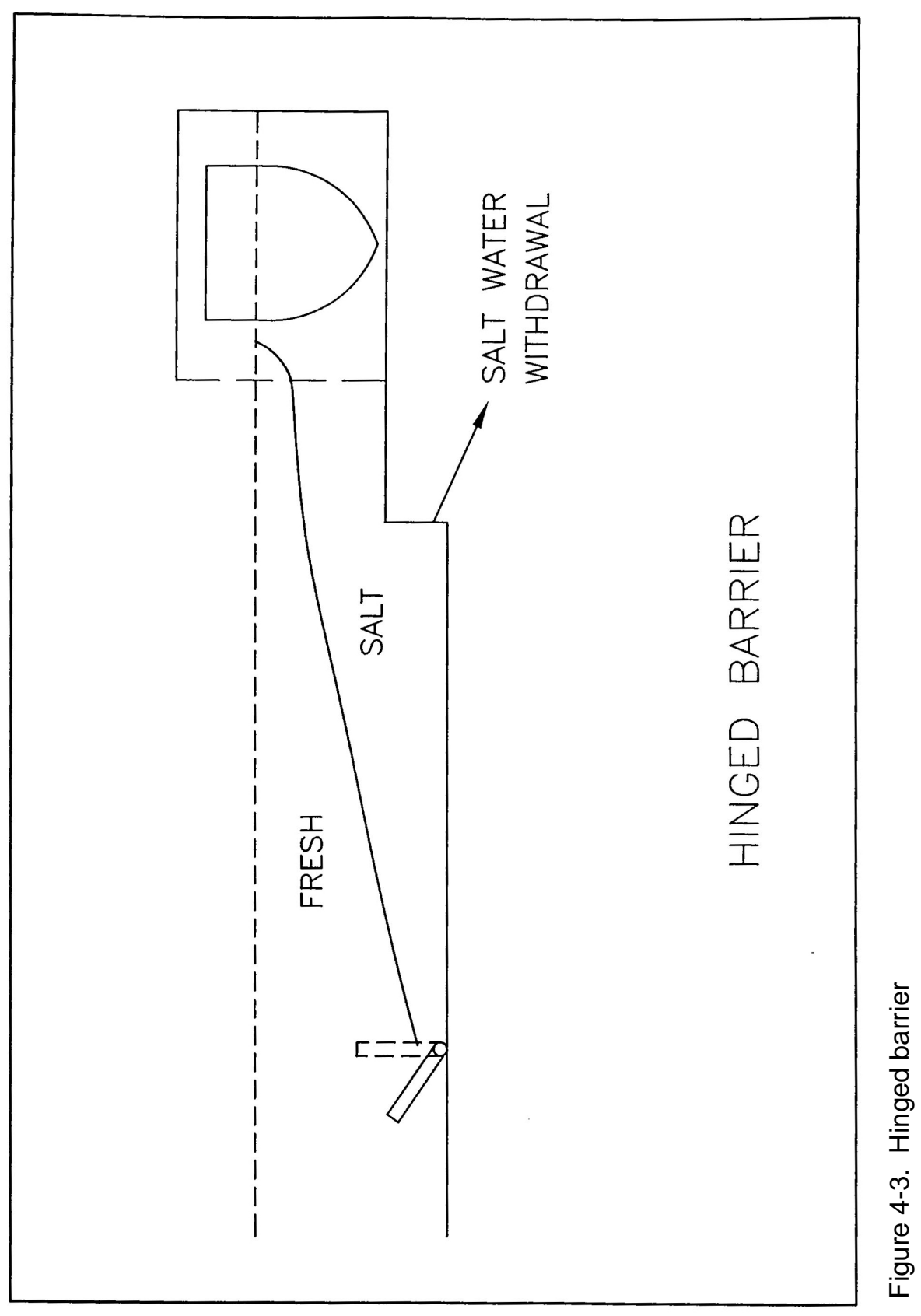




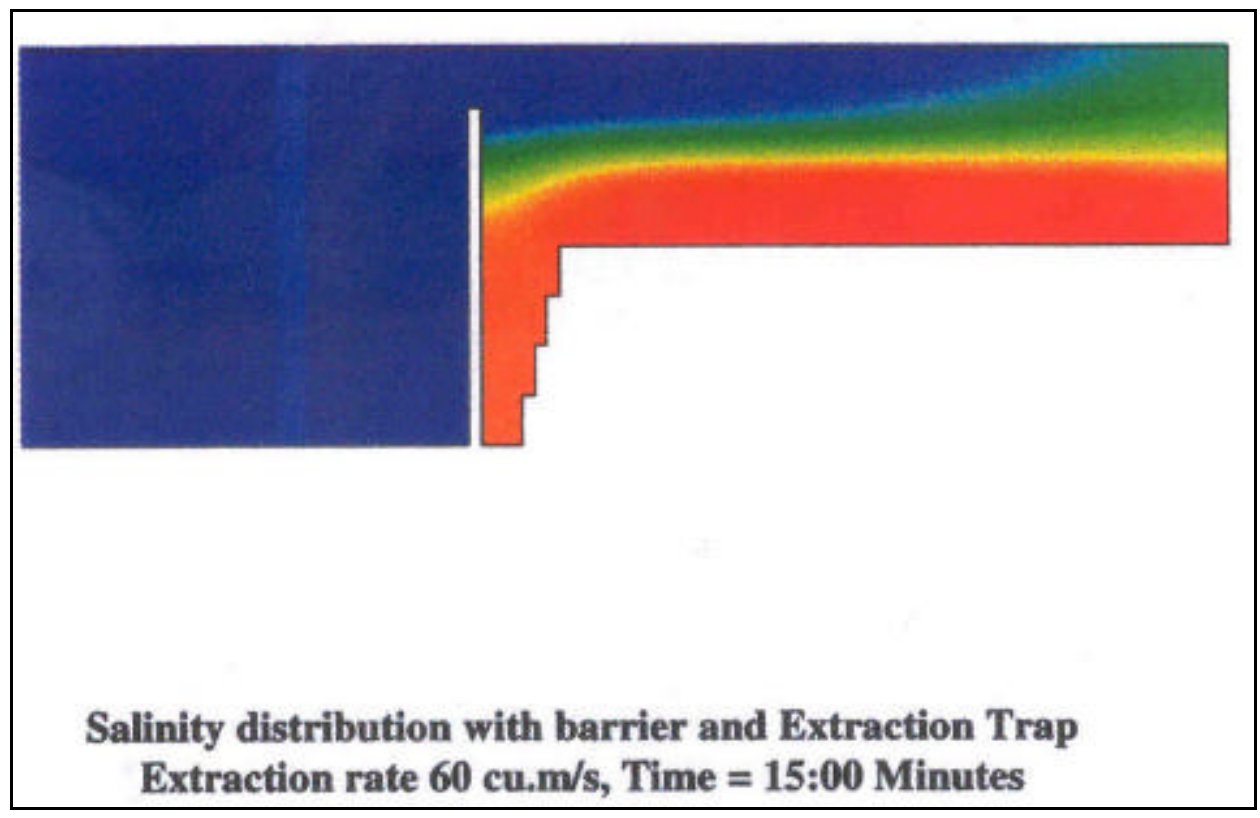

Figure 4-4. Schematical syncrolift lock with gated salt water extraction chamber 


\section{Modeling Density Flows}

The two-dimensional width-averaged numerical model, CE-QUAL-W2, was used to investigate density flow from the uppermost Gatun Lake lock into a navigation channel. A channel sump for collecting and retaining salt water from the locks and a salinity barrier with bottom extraction were simulated. The results of these simulations are summarized here.

\section{Model and Assumptions}

CE-QUAL-W2 is a time-varying, mechanistic, two-dimensional (verticallongitudinal) hydrodynamic and water quality reservoir model. The model is capable of simulating an extensive list of chemical and biological and hydrodynamic processes that affect water quality of a reservoir. This includes the impacts of density stratification due to temperature or salinity. The model assumes lateral homogeneity and is best suited for water-bodies exhibiting longitudinal and vertical water quality gradients. The model has been applied to rivers, lakes, reservoirs, and estuaries and simulates the effects on reservoir water. Details of the model are provided by Environmental and Hydraulics Laboratory (1986) and Cole and Buchak (1995).

Two computational grids were developed for modeling Gatun Lake salinity intrusion. The segment distribution (longitudinal cell lengths) used for both computational grids is shown in Figures 5-1 and 5-2. The ship lift was $250 \mathrm{~m}$ long by $28 \mathrm{~m}$ wide by $10 \mathrm{~m}$ deep, the sump was $500 \mathrm{~m}$ long by $100 \mathrm{~m}$ wide by $10 \mathrm{~m}$ deep. The upper entrance canal was $750 \mathrm{~m}$ long by $100 \mathrm{~m}$ wide by $10 \mathrm{~m}$ deep. The numerical model does not allow moving boundaries, thus a ship was not simulated in the grid. The first grid simulated a Syncrolift lock chamber opening into a 100 -m-wide canal with a 10 -m-deep by 500 -m-long salinity collection sump (Figure 5-3). During lock operation, the sump was to collect salt water and then drain the salt water back to the sea. The second grid simulated a barrier gate (Figure 5-4) to retain escaping salt water with simultaneous extraction through a bottom withdrawal. The barrier gate was located $35 \mathrm{~m}$ upstream of the entrance to the ship lift with a crest set at $3 \mathrm{~m}$ deep. The extraction sump was 10-m deep between the barrier gate and the ship lift. For the extraction simula-tions, a large reservoir width (1000 $\mathrm{m}$ at the upstream end) was simulated outside of the immediate vicinity of the ship lift to provide a large 
reservoir surface area. This allowed the withdrawal of water without significantly lowering the pool.

\section{Experimental Conditions}

Several data files were assembled to describe the initial salinity conditions across the computational grid. In the simulated part of Gatun Lake, the salinity was set at 0 , while salinity within the ship lift was homogeneous and initially set at $5 \mathrm{ppt}$ and $10 \mathrm{ppt}$ for different simulations. Water temperature was set at a constant $30^{\circ} \mathrm{C}$ for the entire grid and did not vary during model operation.

The initial conditions were defined to simulate the instantaneous opening of the ship lift gates. The model runs simulated up to 2 hours of time.

\section{Plans Tested}

Tested plans included several variations of a sump to capture salt water carried out of the lock by density flows, following the design of the Lake Washington Ship Canal saltwater sump. Two plans are presented here, a long sump in a lock approach channel with a salt water drain in the end nearest the lock, as depicted in Figure 4-2, and a gated chamber (near-field barrier) built into the lock structure to capture salt water and replace it with fresh water before the gate is opened for ship movement. The latter design concept was developed by the COE-PCC study team during the testing procedure. For both cases the bottom salt water extraction rate was set at $60 \mathrm{~m}^{3} / \mathrm{s}$.

Either of these plans can be used with the existing locks or the Syncrolift lock.

\section{Results}

Salt Water Sump. The dense water within the ship lift slumped out toward the upstream channel, cascading down into the salinity sump in the approach channel (Video 1). The salinity filled the sump with concentrations greater than 0.5 ppt. Even though the numerical model was more diffusive than the actual conditions would be, these results showed that more fresh water would likely be used to drain the salinity sump than would be used for a conventional lock operation. Thus, this alternative was modified to simulate the near-field barrier with bottom extraction.

Near-Field Barrier. The results of this simulation are presented in Video 2 and Video 3. The salt water slumps into the trap when the lock gate is opened and is withdrawn through the bottom. Fresh water from the approach channel skims in over the barrier gate to replace the salt water that has been withdrawn. The velocity of the freshwater over the barrier gate prevents salt water from escaping into the approach channel. Video 4 shows the particle tracks from this simulation. This alternative captures the salt water and removes it before it can 
escape into the lake, but introduces currents over the barrier that may cause ship motion within the lock.

\section{Recommendations}

This numerical model offers the capability to quickly simulate and assess stratified flow during lock operation. Once it has been verified, it can be used in a design-level effort.

Of the two alternatives simulated in the model, the near-field salinity barrier with bottom extraction appears most feasible. The canal sump for trapping salt water would likely result in excessive use of freshwater to flush the large volume of saltwater/freshwater mixture from the sump. The near-field barrier with bottom extraction showed better promise of salinity exclusion provided by the velocity pattern over the barrier. Further research should be conducted into the extraction alternative to determine the maximum time allowable for the saltwater exchange and the degree to which this alternative can meet this requirement. Effects on vessels within the lock and variations in barrier depth and extraction rates and, in concert with other alternatives, such as in-lock flushing, should be included in more detailed studies for design purposes. 
Table 5.1 (Concluded)

\begin{tabular}{|c|c|c|c|c|c|c|c|c|c|c|c|c|c|c|c|c|c|c|c|c|c|c|}
\hline \multicolumn{13}{|c|}{ Panama Canal } & & \multirow{2}{*}{\multicolumn{3}{|c|}{$\begin{array}{c}\text { Number of Syncro Lift } \\
\text { Lockages per time interval } \\
\end{array}$}} & & & & & \multirow{2}{*}{\multicolumn{2}{|c|}{$\begin{array}{l}\text { Computation of Trib Inflow to } \\
\text { Gatun }\end{array}$}} \\
\hline \multicolumn{5}{|c|}{$\begin{array}{c}\text { Flows and time interval are based on the } \\
\text { number of lockages }\end{array}$} & 13870 & & & & & & & & & & & & 7300 & & & & & \\
\hline \multirow[b]{2}{*}{$\begin{array}{c}\text { Time } \\
\text { Interval }\end{array}$} & \multirow[b]{2}{*}{$\begin{array}{l}\text { Salinity - } \\
\text { LG ppt }\end{array}$} & \multirow[b]{2}{*}{$\begin{array}{l}\text { Volume - } \\
\text { LG cf }\end{array}$} & \multicolumn{4}{|c|}{\begin{tabular}{|c|} 
Average Madden Lake and Tributary \\
Inflow for time interval
\end{tabular}} & \multicolumn{3}{|c|}{$\begin{array}{c}\text { Exchange during lift operations } \\
\text { Pedro Miguel Lock }\end{array}$} & \multicolumn{3}{|c|}{$\begin{array}{l}\text { Exchange during lift } \\
\text { operations Gatun Lock }\end{array}$} & \multirow{2}{*}{$\begin{array}{l}\begin{array}{l}\text { Mass of } \\
\text { salt, lbs }\end{array} \\
\text { lock, ppt } \\
\end{array}$} & \multicolumn{3}{|c|}{$\begin{array}{c}\text { Exchange during lift operations } \\
\text { Miraflores Syncrolift }\end{array}$} & \multicolumn{3}{|c|}{$\begin{array}{c}\text { Exchange during lift operations } \\
\text { Gatun Syncrolift }\end{array}$} & Mass of & salt, Ibs & \\
\hline & & & $\underset{\mathrm{cf}}{\text { Spill - ML, }}$ & $\begin{array}{c}\text { Qpower - } \\
\text { ML, cf } \\
\end{array}$ & $\begin{array}{c}\text { Trib - LG, } \\
\text { cf }\end{array}$ & $\begin{array}{l}\text { Salinity - } \\
\text { ML, cf }\end{array}$ & Qlock, cf & \begin{tabular}{|c|}
$\begin{array}{c}\text { Phi } \\
\text { portion of } \\
\text { lock }\end{array}$ \\
\end{tabular} & $\begin{array}{l}\text { Salinity - } \\
\text { lock, ppt }\end{array}$ & Qlock, cf & $\begin{array}{c}\begin{array}{c}\text { Phi } \\
\text { portion of } \\
\text { lock }\end{array} \\
\end{array}$ & Salinity. & & Qlock, cf & $\begin{array}{c}\begin{array}{c}\text { Phi } \\
\text { portion of } \\
\text { lock }\end{array} \\
\end{array}$ & $\begin{array}{l}\text { Salinity - } \\
\text { lock, ppt }\end{array}$ & Qlock, cf & \begin{tabular}{|c|}
$\begin{array}{c}\text { Phi } \\
\text { portion of } \\
\text { lock }\end{array}$ \\
\end{tabular} & Salinity - & lock, ppt & $\begin{array}{c}\text { Total } \\
\text { Inflow, cf }\end{array}$ & $\begin{array}{l}\text { Less Madden } \\
\text { Releases, cf } \\
\end{array}$ \\
\hline & & & \begin{tabular}{|l}
$5.73 E+09$ \\
\end{tabular} & 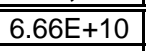 & $4.53 \mathrm{E}+10$ & 0.00 & $5.12 \mathrm{E}+10$ & & 0.100 & $5.45 \mathrm{E}+10$ & 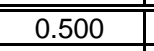 & 0.100 & & $8.74 \mathrm{E}+09$ & & 0.300 & $8.74 \mathrm{E}+09$ & & $\begin{array}{ll}0.300 \\
0\end{array}$ & (p) & & \\
\hline 53 & 0.044 & $\frac{1.02 \mathrm{~L}+11}{1.82 \mathrm{E}+11}$ & \begin{tabular}{|l|}
$.75 \mathrm{TL}+09$ \\
\end{tabular} & $\frac{\frac{0.00+10}{6.66 \mathrm{E}+10}}{2}$ & \begin{tabular}{|l|l}
$.535+10$ \\
$4.53 \mathrm{E}+10$
\end{tabular} & 0.00 & $\begin{array}{l}\frac{3.12 E+10}{5.12 E+10} \\
\mid\end{array}$ & 0.0000 & 0.100 & $5.45 \mathrm{E}+10$ & 0.500 & 0 & & \begin{tabular}{l|l|l}
$8.74 E+09$ \\
\end{tabular} & 0.500 & 0.300 & \begin{tabular}{l|l|}
$8.74 \mathrm{E}+09$ \\
\end{tabular} & 0.500 & 0.300 & & & \\
\hline 54 & 0.044 & $1.82 \mathrm{E}+11$ & \begin{tabular}{|l|}
$5.73 \mathrm{E}+09$ \\
\end{tabular} & $6.66 \mathrm{E}+10$ & \begin{tabular}{|l|}
$4.53 \mathrm{E}+10$ \\
\end{tabular} & 0.00 & $5.12 \mathrm{E}+10$ & 0.500 & 0.100 & $5.45 \mathrm{E}+10$ & 0.500 & 0.100 & & $8.74 \mathrm{E}+09$ & 0.500 & 0.300 & $8.74 \mathrm{E}+09$ & 0.500 & 0.300 & & & \\
\hline 55 & 0.044 & $1.82 \mathrm{E}+11$ & $5.73 \mathrm{E}+09 \mid$ & $6.66 \mathrm{E}+10$ & $4.53 \mathrm{E}+10$ & 0.00 & $5.12 \mathrm{E}+10$ & 0.500 & 0.100 & $5.45 \mathrm{E}+10$ & 0.500 & 0.100 & & $8.74 \mathrm{E}+09$ & 0.500 & 0.300 & $8.74 \mathrm{E}+09$ & 0.500 & 0.300 & & & \\
\hline 56 & 0.044 & $1.82 \mathrm{E}+11$ & $5.73 \mathrm{E}+09 \mid$ & $6.66 \mathrm{E}+10$ & $4.53 \mathrm{E}+10$ & 0.00 & $5.12 \mathrm{E}+10$ & 0.500 & 0.100 & $5.45 \mathrm{E}+10$ & 0.500 & 0.100 & & $8.74 \mathrm{E}+09$ & 0.500 & 0.300 & $8.74 \mathrm{E}+09$ & 0.500 & 0.300 & & & \\
\hline 57 & 0.044 & $1.82 \mathrm{E}+11$ & $5.73 \mathrm{E}+09$ & $6.66 \mathrm{E}+10$ & $4.53 \mathrm{E}+10$ & 0.00 & $5.12 \mathrm{E}+10$ & 0.500 & 0.100 & $5.45 \mathrm{E}+10$ & 0.500 & 0.100 & & $8.74 \mathrm{E}+09$ & 0.500 & 0.300 & $8.74 \mathrm{E}+09$ & 0.500 & 0.300 & & & \\
\hline 58 & 0.044 & $1.82 \mathrm{E}+11$ & $5.73 \mathrm{E}+09$ & $6.66 \mathrm{E}+10$ & $4.53 \mathrm{E}+10$ & 0.00 & $5.12 \mathrm{E}+10$ & 0.500 & 0.100 & $5.45 \mathrm{E}+10$ & 0.500 & 0.100 & & $8.74 \mathrm{E}+09$ & 0.500 & 0.300 & $8.74 \mathrm{E}+09$ & 0.500 & 0.300 & & & \\
\hline 59 & 0.044 & $1.82 \mathrm{E}+11$ & $5.73 \mathrm{E}+09$ & $6.66 \mathrm{E}+10$ & $4.53 \mathrm{E}+10$ & 0.00 & $5.12 \mathrm{E}+10$ & 0.500 & 0.100 & $5.45 \mathrm{E}+10$ & 0.500 & 0.100 & & $8.74 E+09$ & 0.500 & 0.300 & $8.74 \mathrm{E}+09$ & 0.500 & 0.300 & & & \\
\hline 60 & 0.044 & & $5.73 \mathrm{E}+09$ & $6.66 \mathrm{E}+10$ & $4.53 \mathrm{E}+10$ & 0.00 & $5.12 \mathrm{E}+10$ & 0.500 & 0.100 & $5.45 \mathrm{E}+10$ & 0.500 & 0.100 & & $8.74 \mathrm{E}+09$ & 0.500 & 0.300 & $8.74 \mathrm{E}+09$ & 0.500 & 0.300 & & & \\
\hline 61 & 0.044 & $1.82 \mathrm{E}+11$ & $5.73 \mathrm{E}+09$ & $6.66 \mathrm{E}+10$ & $4.53 \mathrm{E}+10$ & 0.00 & $5.12 \mathrm{E}+10$ & 0.500 & 0.100 & $5.45 \mathrm{E}+10$ & 0.500 & 0.100 & & $8.74 \mathrm{E}+09$ & 0.500 & 0.300 & $8.74 \mathrm{E}+09$ & 0.500 & 0.300 & & & \\
\hline 62 & 0.044 & $1.82 \mathrm{E}+11$ & $5.73 \mathrm{E}+09$ & $6.66 \mathrm{E}+10$ & $4.53 \mathrm{E}+10$ & 0.00 & $5.12 \mathrm{E}+10$ & 0.500 & 0.100 & $5.45 \mathrm{E}+10$ & 0.500 & 0.100 & & $8.74 \mathrm{E}+09$ & 0.500 & 0.300 & $8.74 \mathrm{E}+09$ & 0.500 & 0.300 & & & \\
\hline 63 & 0.044 & $\frac{1.82 \mathrm{E}+11}{1.82 \mathrm{E}}$ & $5.73 \mathrm{E}+09$ & $6.66 \mathrm{E}+10$ & 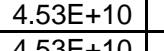 & 0.00 & $5.12 \mathrm{E}+10$ & 0.500 & $\begin{array}{l}0.100 \\
0100\end{array}$ & $5.45 \mathrm{E}+10$ & 0.500 & 0.100 & & $8.74 \mathrm{E}+09$ & 0.500 & 0.300 & $8.74 \mathrm{E}+09$ & 0.500 & 0.300 & & & \\
\hline 64 & 0.044 & $\frac{1.82 \mathrm{E}+11}{182 \mathrm{~F}}$ & $|5.73 \mathrm{E}+09|$ & $6.66 \mathrm{E}+10$ & \begin{tabular}{|l|l}
$4.53 \mathrm{E}+10$ \\
$45 \mathrm{~S}$
\end{tabular} & 0.00 & $\frac{5.12 \mathrm{E}+10}{5.2 \mathrm{~F}}$ & 0.500 & $\begin{array}{l}0.100 \\
0100\end{array}$ & $5.45 \mathrm{E}+10$ & 0.500 & 0.100 & & $8.74 \mathrm{E}+09$ & 0.500 & 0.300 & $8.74 \mathrm{E}+09$ & 0.500 & 0.300 & & & \\
\hline$\frac{65}{66}$ & $\frac{0.044}{0.044}$ & $\frac{1.82 \mathrm{E}+11}{1.82 \mathrm{E}+11}$ & \begin{tabular}{|l|}
$5.73 \mathrm{E}+09$ \\
$5.7 \mathrm{E}+09$
\end{tabular} & $\frac{6.66 \mathrm{E}+10}{6.6 \mathrm{E}+10}$ & \begin{tabular}{|l|}
$4.53 \mathrm{E}+10$ \\
$4.55 \mathrm{E}+10$
\end{tabular} & $\frac{0.00}{0.00}$ & $\frac{5.12 E+10}{5.12 E+10}$ & 0.500 & $\begin{array}{l}0.100 \\
0.100\end{array}$ & $\frac{5.45 \mathrm{E}+10}{5.54 \mathrm{E}+1}$ & $\frac{0.500}{0.500}$ & $\frac{0.100}{0.100}$ & & 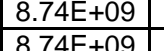 & 0.500 & 0.300 & $8.74 \mathrm{E}+09$ & 0.500 & 0.300 & & & \\
\hline$\frac{66}{67}$ & $\frac{0.044}{0.044}$ & $\frac{1.82 \mathrm{E}+11}{1.82 \mathrm{E}+11}$ & \begin{tabular}{|l|}
$\mid 5.17 \mathrm{E}+09$ \\
$5.3 \mathrm{E}+09$
\end{tabular} & $\frac{6.66 \mathrm{E}+10}{6.66 \mathrm{E}+10}$ & \begin{tabular}{|l|l}
$4.53 \mathrm{E}+10$ \\
$4.53 \mathrm{E}+10$
\end{tabular} & $\frac{0.00}{0.00}$ & $\frac{5.12 \mathrm{E}+10}{5.12 \mathrm{E}+10}$ & $\frac{0.500}{0.500}$ & $\frac{0.100}{0.100}$ & $\frac{5.45 \mathrm{E}+10}{5.45 \mathrm{E}+10}$ & $\frac{0.500}{0.500}$ & $\frac{0.100}{0.100}$ & & $\begin{array}{l}8.74 \mathrm{E}+09 \\
8.74 \mathrm{E}+09\end{array}$ & $\frac{0.500}{0.500}$ & $\frac{0.300}{0.300}$ & $\frac{8.4 \mathrm{E}+09}{8.74 \mathrm{E}+09}$ & $\frac{0.500}{0.500}$ & $\frac{0.300}{0.300}$ & & & \\
\hline 68 & 0.044 & $1.82 \mathrm{E}+11$ & $5.73 \mathrm{E}+09$ & $6.66 \mathrm{E}+10$ & $4.53 \mathrm{E}+10$ & 0.00 & $5.12 \mathrm{E}+10$ & 0.500 & 0.100 & $5.45 \mathrm{E}+10$ & 0.500 & 0.100 & & $8.74 \mathrm{E}+09$ & 0.500 & 0.300 & $8.74 \mathrm{E}+09$ & 0.500 & 0.300 & & & \\
\hline 69 & 0.044 & $1.82 \mathrm{E}+11$ & $5.73 \mathrm{E}+09$ & $6.66 \mathrm{E}+10$ & $4.53 \mathrm{E}+10$ & 0.00 & $5.12 \mathrm{E}+10$ & 0.500 & 0.100 & $5.45 \mathrm{E}+10$ & 0.500 & 0.100 & & $8.74 \mathrm{E}+09$ & 0.500 & 0.300 & $8.74 \mathrm{E}+09$ & 0.500 & 0.300 & & & \\
\hline 70 & 0.044 & $1.82 \mathrm{E}+11$ & $5.73 E+$ & $6.66 \mathrm{E}+10$ & $4.53 \mathrm{E}+10$ & 0.00 & $5.12 \mathrm{E}+10$ & 0.500 & 0.100 & $5.45 \mathrm{E}+10$ & 0.500 & 0.100 & & $8.74 \mathrm{E}+09$ & 0.500 & 0.300 & $8.74 \mathrm{E}+09$ & 0.500 & 0.300 & & & \\
\hline 71 & 0.044 & & $5.73 E+1$ & $6.66 \mathrm{E}+10$ & $4.53 \mathrm{E}+10$ & 0.00 & $5.12 \mathrm{E}+10$ & & 0.100 & $5.45 \mathrm{E}+10$ & 0.500 & 0.100 & & $8.74 \mathrm{E}+09$ & 0.500 & 0.300 & $8.74 \mathrm{E}+09$ & & 0.300 & & & \\
\hline 72 & 0.044 & $1.82 \mathrm{E}+11$ & \begin{tabular}{|l}
$5.73 E+09$ \\
\end{tabular} & $6.66 \mathrm{E}+10$ & $4.53 \mathrm{E}+10$ & 0.00 & $5.12 \mathrm{E}+10$ & 0.500 & 0.100 & $5.45 \mathrm{E}+10$ & 0.500 & 0.100 & & $8.74 \mathrm{E}+09$ & 0.500 & 0.300 & $8.74 \mathrm{E}+09$ & 0.500 & 0.300 & & & \\
\hline 73 & 0.044 & $1.82 \mathrm{E}+11$ & $5.73 \mathrm{E}+09$ & $6.66 \mathrm{E}+10$ & $4.53 \mathrm{E}+10$ & 0.00 & $5.12 \mathrm{E}+10$ & 0.500 & 0.100 & $5.45 \mathrm{E}+10$ & 0.500 & 0.100 & & $8.74 \mathrm{E}+09$ & 0.500 & 0.300 & $8.74 \mathrm{E}+09$ & 0.500 & 0.300 & & & \\
\hline 74 & 0.044 & $1.82 \mathrm{E}+11$ & $5.73 \mathrm{E}+09$ & $6.66 \mathrm{E}+10$ & $4.53 \mathrm{E}+10$ & 0.00 & $5.12 \mathrm{E}+10$ & 0.500 & 0.100 & $5.45 \mathrm{E}+10$ & 0.500 & 0.100 & & $8.74 \mathrm{E}+09$ & 0.500 & 0.300 & $8.74 \mathrm{E}+09$ & 0.500 & 0.300 & & & \\
\hline $\begin{array}{l}75 \\
76\end{array}$ & 0.044 & $\frac{1.82 \mathrm{E}+11}{1.82 \mathrm{E}}$ & $|5.73 \mathrm{E}+09|$ & $6.66 \mathrm{E}+10$ & \begin{tabular}{|c|}
$4.53 \mathrm{E}+10$ \\
$553 \mathrm{E}$
\end{tabular} & 0.00 & $5.12 \mathrm{E}+10$ & 0.500 & $\begin{array}{l}0.100 \\
0100\end{array}$ & $5.45 \mathrm{E}+10$ & 0.500 & 0.100 & & $8.74 \mathrm{E}+09$ & 0.500 & 0.300 & $8.74 \mathrm{E}+09$ & 0.500 & 0.300 & & & \\
\hline$\frac{76}{77}$ & $\frac{0.044}{0.044}$ & \begin{tabular}{|c|c|c|}
$1.82 E+11$ \\
$182 E+11$
\end{tabular} & \begin{tabular}{|l|}
$5.73 \mathrm{E}+09$ \\
$57 \mathrm{E}+09$
\end{tabular} & $\frac{6.66 \mathrm{E}+10}{6.6 \mathrm{E}+10}$ & \begin{tabular}{|l|}
$4.53 \mathrm{E}+10$ \\
$45 \mathrm{E}+10$
\end{tabular} & $\frac{0.00}{0.00}$ & $\frac{5.12 E+10}{5.2 E+12}$ & 0.500 & $\frac{0.100}{0.100}$ & $\frac{5.45 \mathrm{E}+10}{5.45 \mathrm{E}+1}$ & 0.500 & 0.100 & & $8.74 \mathrm{E}+09$ & 0.500 & 0.300 & $8.74 \mathrm{E}+09$ & 0.500 & 0.300 & & & \\
\hline 78 & $\frac{0.044}{0.044}$ & $\frac{1.82 \mathrm{E}+11}{1.82 \mathrm{E}+11}$ & \begin{tabular}{|l|}
$\mid 5 . / 7 \mathrm{E}+09$ \\
$5.33 E+09$
\end{tabular} & $\frac{6.66 \mathrm{E}+10}{6.6 \mathrm{E}+10}$ & \begin{tabular}{|c|c|c|c|}
$4.53 E+10$ \\
$4.53 E+10$
\end{tabular} & 0.00 & $\frac{5.12 E+10}{5.12 E+10}$ & $\frac{0.500}{0.500}$ & $\frac{0.100}{0.100}$ & $\frac{5.45 E+10}{5.45 E+10}$ & $\frac{0.500}{0.500}$ & $\frac{0.100}{0.100}$ & & $\frac{8.4 \mathrm{E}+09}{874 \mathrm{~F}+9}$ & $\frac{0.500}{0.500}$ & $\frac{0.300}{0.300}$ & $\frac{8.4 \mathrm{E}+09}{874 \mathrm{~F}+9}$ & $\frac{0.500}{0.500}$ & $\frac{0.300}{0.300}$ & & & \\
\hline$\frac{10}{79}$ & 0.044 & $\frac{1.02 \mathrm{~L}+11}{1.82 \mathrm{E}+11}$ & \begin{tabular}{|l|}
$.17 \mathrm{CL}+\mathrm{U}$ \\
$5.3 \mathrm{E}+\mathrm{s}$
\end{tabular} & $\frac{0.00 \mathrm{E}+10}{6.66 \mathrm{E}+10}$ & $\begin{array}{l}4.03 \mathrm{C}+\mathrm{I0} \\
4.53 \mathrm{E}+10\end{array}$ & 0.00 & $\frac{5.12 \mathrm{E}+10}{5.12 \mathrm{E}+10}$ & $\frac{0.500}{0.500}$ & $\frac{0.100}{0.100}$ & $\frac{5.45 \mathrm{E}+10}{5.45 \mathrm{E}+10}$ & $\frac{0.500}{0.500}$ & $\frac{0.100}{0.100}$ & & $\frac{8.14 \mathrm{E}+09}{8.74 \mathrm{E}+09}$ & 0.000 & $\frac{0.300}{0.300}$ & $\begin{array}{l}8.74 \mathrm{E}+09 \\
8.74 \mathrm{E}+09\end{array}$ & $\frac{0.500}{0.500}$ & $\frac{0.300}{0.300}$ & & & \\
\hline 80 & 0.044 & $1.82 \mathrm{E}+11$ & $5.73 \mathrm{E}+\mathrm{C}$ & $6.66 \mathrm{E}+10$ & $4.53 \mathrm{E}+10$ & 0.00 & $5.12 \mathrm{E}+10$ & 0.500 & 0.100 & $5.45 \mathrm{E}+10$ & 0.500 & 0.1 & & $8.74 \mathrm{E}+09$ & 0.500 & 0.300 & $8.74 \mathrm{E}+09$ & 0.500 & 0.300 & & & \\
\hline 81 & 0.044 & $1.82 \mathrm{E}+11$ & $5.73 \mathrm{E}+$ & $6.66 \mathrm{E}+10$ & $4.53 \mathrm{E}+10$ & 0.00 & $5.12 \mathrm{E}+10$ & 0.500 & 0.100 & $5.45 \mathrm{E}+10$ & 0.500 & 0.100 & & $8.74 \mathrm{E}+09$ & 0.500 & 0.300 & $8.74 \mathrm{E}+09$ & 0.500 & 0.300 & & & \\
\hline 82 & 0.044 & & $5.73 E+$ & $6.66 \mathrm{E}+10$ & $4.53 \mathrm{E}+10$ & 0.00 & $5.12 \mathrm{E}+10$ & 0.500 & 0.100 & $5.45 \mathrm{E}+10$ & 0.500 & 0.100 & & $8.74 \mathrm{E}+09$ & 0.500 & 0.300 & $8.74 \mathrm{E}+09$ & & 0.300 & & & \\
\hline 83 & 0.044 & $1.82 \mathrm{E}+11$ & $5.73 \mathrm{E}+$ & $6.66 \mathrm{E}+10$ & $4.53 \mathrm{E}+10$ & 0.00 & & 0.500 & 0.100 & $5.45 \mathrm{E}+10$ & 0.500 & 0.11 & & $8.74 \mathrm{E}+09$ & 0.500 & 0.300 & $8.74 \mathrm{E}+09$ & 0.500 & 0.300 & & & \\
\hline 84 & 0.044 & $1.82 \mathrm{E}+11$ & \begin{tabular}{|l}
$5.73 E+09$ \\
\end{tabular} & $6.66 \mathrm{E}+10$ & $4.53 \mathrm{E}+10$ & 0.00 & $5.12 \mathrm{E}+10$ & 0.500 & 0.100 & $5.45 \mathrm{E}+10$ & 0.500 & 0.1 & & $8.74 \mathrm{E}+09$ & 0.500 & 0.300 & $8.74 \mathrm{E}+09$ & 0.500 & 0.30 & & & \\
\hline 85 & 0.044 & $1.82 \mathrm{E}+11$ & $5.73 E+09$ & $6.66 \mathrm{E}+10$ & $4.53 \mathrm{E}+10$ & 0.00 & $5.12 \mathrm{E}+10$ & 0.500 & 0.100 & $5.45 \mathrm{E}+10$ & 0.500 & 0.100 & & $8.74 \mathrm{E}+09$ & 0.500 & 0.300 & $8.74 \mathrm{E}+09$ & 0.500 & 0.300 & & & \\
\hline 86 & 0.044 & $1.82 \mathrm{E}+11$ & $5.73 \mathrm{E}+09$ & $6.66 \mathrm{E}+10$ & $4.53 \mathrm{E}+10$ & 0.00 & $5.12 \mathrm{E}+10$ & 0.500 & 0.100 & $5.45 \mathrm{E}+10$ & 0.500 & 0.100 & & $8.74 \mathrm{E}+09$ & 0.500 & 0.300 & $8.74 \mathrm{E}+09$ & 0.500 & 0.3 & & & \\
\hline$\frac{87}{88}$ & 0.044 & $\frac{1.82 \mathrm{E}+11}{1.82 \mathrm{~F}}$ & $5.73 \mathrm{E}+09 \mid$ & $6.66 \mathrm{E}+10$ & \begin{tabular}{|c|}
$4.53 \mathrm{E}+10$ \\
$453 \mathrm{~F}$
\end{tabular} & 0.00 & $\frac{5.12 \mathrm{E}+10}{5.2 \mathrm{~F}}$ & 0.500 & 0.100 & $\frac{5.45 \mathrm{E}+10}{5.45 \mathrm{E}+4}$ & 0.500 & 0.14 & & $8.74 \mathrm{E}+09$ & 0.500 & 0.300 & $8.74 \mathrm{E}+09$ & 0.50 & 0.36 & & & \\
\hline 88 & 0.044 & $\frac{1.82 \mathrm{E}+11}{1.82 \mathrm{E}+11}$ & \begin{tabular}{|l|}
$\mid . / 15 \mathrm{E}+\mathrm{US}$ \\
$5 . \mathrm{E} \mathrm{E}$
\end{tabular} & $\frac{6.06 \mathrm{E}+10}{6.66 \mathrm{E}+10}$ & \begin{tabular}{|l|}
$4.5 \mathrm{SE}+10$ \\
$4.53 \mathrm{E}+10$
\end{tabular} & 0.00 & $\frac{3.12 E+10}{5.12 E+10}$ & 0.500 & $\frac{0.100}{0.100}$ & $\frac{5.45 E+10}{5.45 E+10}$ & $\frac{0.500}{0.500}$ & $\frac{0.11}{0.11}$ & & $\frac{8.14 \mathrm{E}+09}{8.74 \mathrm{E}+09}$ & 0.500 & $\frac{0.300}{0.300}$ & $\frac{8.4 \mathrm{E}+\mathrm{U}}{8.7 \mathrm{E}+09}$ & 0.00 & 0.30 & & & \\
\hline 90 & 0.044 & $1.82 \mathrm{E}+11$ & $5.73 \mathrm{E}+$ & $6.66 \mathrm{E}+10$ & $4.53 \mathrm{E}+10$ & 0.00 & $5.12 \mathrm{E}+10$ & 0.500 & 0.100 & $5.45 \mathrm{E}+10$ & 0.500 & 0.1 & & $8.74 \mathrm{E}+09$ & 0.50 & 0.3 & $8.74 \mathrm{E}+09$ & 0.5 & 0.3 & & & \\
\hline 91 & 0.044 & $1.82 \mathrm{E}+11$ & $5.73 \mathrm{E}_{-}$ & & $4.53 \mathrm{E}+10$ & 0.00 & 5.12E. & 0.500 & 0.100 & $5.45 \mathrm{E}+10$ & 0.500 & 0.1 & & \begin{tabular}{|l|l|l|l}
$8.74 E+09$ \\
\end{tabular} & 0.5 & 0.3 & $8.74 \mathrm{E}+09$ & 0.56 & 0.300 & & & \\
\hline 92 & 0.044 & $1.82 \mathrm{E}+11$ & $5.73 \mathrm{E}_{-}$ & $6.66 \mathrm{E}+$ & $4.53 \mathrm{E}+10$ & 0.00 & $5.12 \mathrm{E}$ & 0.500 & 0.100 & $5.45 \mathrm{E}+10$ & 0.500 & 0.1 & & $8.74 \mathrm{E}$ & 0.50 & 0.3 & $8.74 \mathrm{E}$ & 0.500 & 0.30 & & & \\
\hline 93 & 0.044 & & $5.73 \mathrm{E}$ & $6.66 \mathrm{E}$ & $4.53 \mathrm{E}+10$ & 0.00 & $5.12 \mathrm{E}$ & 0.500 & 0.100 & $5.45 \mathrm{E}+10$ & 0.500 & 0.1 & & $8.74 \mathrm{E}$ & 0.50 & 0.3 & 8.741 & & 0.3 & & & \\
\hline 94 & 0.044 & $1.82 \mathrm{E}+11$ & & & $4.53 \mathrm{E}+10$ & 0.00 & & 0.500 & 0.100 & $5.45 \mathrm{E}+10$ & 0.500 & & & & 0.5 & 0.3 & & & 0.3 & & & \\
\hline 95 & 0.044 & $1.82 \mathrm{E}+11$ & 5.73 & $6.66 \mathrm{E}+10$ & $\begin{array}{ll}4.53 \mathrm{E}+10 \\
\end{array}$ & 0.00 & & 0.500 & 0.100 & $5.45 \mathrm{E}+10$ & 0.500 & 0.1 & & $8.74 E+09$ & 0.500 & 0.30 & $8.74 E+09$ & 0.56 & 0.300 & & & \\
\hline 96 & 0.044 & $1.82 \mathrm{E}+11$ & $5.73 \mathrm{E}+09$ & $6.66 \mathrm{E}+10$ & 4.53E+10 & 0.00 & $5.12 \mathrm{E}+10$ & 0.500 & 0.100 & $5.45 \mathrm{E}+10$ & 0.500 & 0.100 & & $8.74 \mathrm{E}+09$ & 0.500 & 0.300 & $8.74 E+09$ & 0.50 & 0.300 & & & \\
\hline 97 & 0.044 & $1.82 \mathrm{E}+111$ & $5.73 E+09$ & $6.66 E+10$ & $\begin{array}{l}4.53 \mathrm{E}+10 \\
\end{array}$ & 0.00 & $5.12 E+10$ & 0.500 & 0.100 & $5.45 \mathrm{E}+10$ & 0.500 & 0.100 & & $8.74 \mathrm{E}+09$ & 0.500 & 0.300 & $8.74 \mathrm{E}+09$ & 0.500 & 0.3 & & & \\
\hline 98 & 0.044 & & $5.73 \mathrm{E}+09$ & $6.66 \mathrm{E}+10$ & 4.53E+10 & 0.00 & $5.12 \mathrm{E}+10$ & 0.500 & 0.100 & $5.45 \mathrm{E}+10$ & 0.500 & 0.100 & & $8.74 E+09$ & 0.500 & 0.300 & $8.74 \mathrm{E}+09$ & 0.500 & & & & \\
\hline 99 & 0.044 & & $73 \mathrm{E}+09$ & $6.66 E+10$ & $4.53 \mathrm{E}+10$ & 0.00 & $\frac{5.12 \mathrm{E}+10}{5.20}$ & 0.500 & 0.100 & $\frac{5.45 \mathrm{E}+10}{5}$ & 0.500 & 0.100 & & $8.74 \mathrm{E}+09$ & 0.500 & 0.300 & $8.74 E+09$ & 0.500 & & & & \\
\hline 100 & 0.044 & $1.82 \mathrm{E}+11$ & $5.73 E+09$ & $6.66 \mathrm{E}+10$ & 4.53E+10 & 0.00 & & & 0.100 & & 0.500 & 0.100 & & $8.74 \mathrm{E}+09$ & 0.500 & 0.300 & 8.74E +09 & 0.500 & 0.300 & & & \\
\hline
\end{tabular}




\begin{tabular}{|c|c|c|c|c|c|c|c|c|c|c|c|}
\hline \multicolumn{12}{|c|}{$\begin{array}{l}\text { Table } 5.2 \\
\text { Zero-Order }\end{array}$} \\
\hline \multicolumn{12}{|c|}{ Panama Canal } \\
\hline \multirow[b]{3}{*}{$\begin{array}{l}\text { Time } \\
\text { days }\end{array}$} & \multicolumn{4}{|c|}{$\begin{array}{l}\text { Flows are based on the } \\
\text { number of lockages }\end{array}$} & 38 & & & & & & \\
\hline & \multirow[b]{2}{*}{$\begin{array}{l}\text { Salinity - } \\
\text { ML, ppt }\end{array}$} & \multirow[b]{2}{*}{$\begin{array}{l}\text { Volume } \\
\text { cf }\end{array}$} & \multicolumn{2}{|c|}{$\begin{array}{l}\text { Inflow from Pedro } \\
\text { Miguel Lock } \\
\text { Operation }\end{array}$} & \multicolumn{3}{|c|}{ Exchange during lift Operations } & \multicolumn{3}{|c|}{$\begin{array}{l}\text { Exchange during lift } \\
\text { operations }\end{array}$} & \multirow[b]{2}{*}{$\begin{array}{l}\text { Mass of } \\
\text { salt, lbs }\end{array}$} \\
\hline & & & Qlock, cf & $\begin{array}{l}\text { Salinity, } \\
\text { ppt }\end{array}$ & Qlock, cf & $\begin{array}{l}\text { Phi, } \\
\text { portion } \\
\text { of lock }\end{array}$ & $\begin{array}{l}\text { Salinity - } \\
\text { lock, ppt }\end{array}$ & Qlock, cf & $\begin{array}{l}\text { Phi, } \\
\text { portion } \\
\text { of lock }\end{array}$ & $\begin{array}{l}\text { Salinity - } \\
\text { lock, ppt }\end{array}$ & \\
\hline 0 & 0.00 & $8.23 \mathrm{E}+08$ & $9.55 \mathrm{E}+07$ & 0.000 & $1.40 \mathrm{E}+08$ & 0.500 & 0 & $1.49 \mathrm{E}+08$ & 0.500 & 1.500 & $6.98 \mathrm{E}+06$ \\
\hline 1 & 0.11 & $8.23 E+08$ & $9.55 \mathrm{E}+07$ & 0.000 & $1.40 \mathrm{E}+08$ & 0.500 & 0.10 & $1.49 \mathrm{E}+08$ & 0.500 & 1.500 & \\
\hline 2 & 0.20 & $8.23 \mathrm{E}+08$ & $9.55 \mathrm{E}+07$ & 0.000 & $1.40 \mathrm{E}+08$ & 0.500 & 0.10 & $1.49 \mathrm{E}+08$ & 0.500 & 1.500 & \\
\hline 3 & 0.27 & $8.23 E+08$ & $9.55 \mathrm{E}+07$ & 0.000 & $1.40 \mathrm{E}+08$ & 0.500 & 0.10 & $1.49 E+08$ & 0.500 & 1.500 & \\
\hline 4 & 0.32 & $8.23 \mathrm{E}+08$ & $9.55 \mathrm{E}+07$ & 0.000 & $1.40 \mathrm{E}+08$ & 0.500 & 0.10 & $1.49 \mathrm{E}+08$ & 0.500 & 1.500 & \\
\hline 5 & 0.36 & $8.23 \mathrm{E}+08$ & $9.55 \mathrm{E}+07$ & 0.000 & $1.40 \mathrm{E}+08$ & 0.500 & 0.10 & $1.49 \mathrm{E}+08$ & 0.500 & 1.500 & \\
\hline 6 & 0.39 & $8.23 \mathrm{E}+08$ & $9.55 \mathrm{E}+07$ & 0.000 & $1.40 \mathrm{E}+08$ & 0.500 & 0.10 & $1.49 \mathrm{E}+08$ & 0.500 & 1.500 & \\
\hline 7 & 0.41 & $8.23 \mathrm{E}+08$ & $9.55 \mathrm{E}+07$ & 0.000 & $1.40 \mathrm{E}+08$ & 0.500 & 0.10 & $1.49 \mathrm{E}+08$ & 0.500 & 1.500 & \\
\hline 8 & 0.43 & $8.23 \mathrm{E}+08$ & $9.55 \mathrm{E}+07$ & 0.000 & $1.40 \mathrm{E}+08$ & 0.500 & 0.10 & $1.49 \mathrm{E}+08$ & 0.500 & 1.500 & \\
\hline 9 & 0.45 & $8.23 E+08$ & $9.55 \mathrm{E}+07$ & 0.000 & $1.40 \mathrm{E}+08$ & 0.500 & 0.10 & $1.49 \mathrm{E}+08$ & 0.500 & 1.500 & \\
\hline 10 & 0.46 & $8.23 E+08$ & $9.55 \mathrm{E}+07$ & 0.000 & $1.40 \mathrm{E}+08$ & 0.500 & 0.10 & $1.49 \mathrm{E}+08$ & 0.500 & 1.500 & \\
\hline 11 & 0.47 & $8.23 E+08$ & $9.55 \mathrm{E}+07$ & 0.000 & $1.40 \mathrm{E}+08$ & 0.500 & 0.10 & $1.49 E+08$ & 0.500 & 1.500 & \\
\hline 12 & 0.47 & $8.23 E+08$ & $9.55 \mathrm{E}+0$ & 0.000 & $1.40 \mathrm{E}+08$ & 0.500 & 0.10 & $1.49 \mathrm{E}+08$ & 0.500 & 1.500 & \\
\hline 13 & 0.48 & $8.23 \mathrm{E}+08$ & $9.55 \mathrm{E}+07$ & 0.000 & $1.40 \mathrm{E}+08$ & 0.500 & 0.10 & $1.49 \mathrm{E}+08$ & 0.500 & 1.500 & \\
\hline 14 & 0.48 & $8.23 E+08$ & $9.55 \mathrm{E}+07$ & 0.000 & $1.40 \mathrm{E}+08$ & 0.500 & 0.10 & $1.49 E+08$ & 0.500 & 1.500 & \\
\hline 15 & 0.48 & $8.23 \mathrm{E}+08$ & $9.55 \mathrm{E}+07$ & 0.000 & $1.40 \mathrm{E}+08$ & 0.500 & 0.10 & $1.49 \mathrm{E}+08$ & 0.500 & 1.500 & \\
\hline 16 & 0.49 & $8.23 E+08$ & $9.55 \mathrm{E}+07$ & 0.000 & $1.40 \mathrm{E}+08$ & 0.500 & 0.10 & $1.49 \mathrm{E}+08$ & 0.500 & 1.500 & \\
\hline 17 & 0.49 & $8.23 E+08$ & $9.55 \mathrm{E}+07$ & 0.000 & $1.40 \mathrm{E}+08$ & 0.500 & 0.10 & $1.49 E+08$ & 0.500 & 1.500 & \\
\hline 18 & 0.49 & $8.23 \mathrm{E}+08$ & $9.55 \mathrm{E}+07$ & 0.000 & $1.40 \mathrm{E}+08$ & 0.500 & 0.10 & $1.49 \mathrm{E}+08$ & 0.500 & 1.500 & \\
\hline 19 & 0.49 & $8.23 \mathrm{E}+08$ & $9.55 \mathrm{E}+07$ & 0.000 & $1.40 \mathrm{E}+08$ & 0.500 & 0.10 & $1.49 \mathrm{E}+08$ & 0.500 & 1.500 & \\
\hline 20 & 0.49 & $8.23 E+08$ & $9.55 \mathrm{E}+07$ & 0.000 & $1.40 \mathrm{E}+08$ & 0.500 & 0.10 & $1.49 \mathrm{E}+08$ & 0.500 & 1.500 & \\
\hline 21 & 0.49 & $8.23 \mathrm{E}+08$ & $9.55 \mathrm{E}+07$ & 0.000 & $1.40 \mathrm{E}+08$ & 0.500 & 0.10 & $1.49 \mathrm{E}+08$ & 0.500 & 1.500 & \\
\hline 22 & 0.49 & $8.23 \mathrm{E}+08$ & $9.55 \mathrm{E}+07$ & 0.000 & $1.40 \mathrm{E}+08$ & 0.500 & 0.10 & $1.49 \mathrm{E}+08$ & 0.500 & 1.500 & \\
\hline 23 & 0.49 & $8.23 E+08$ & $9.55 \mathrm{E}+07$ & 0.000 & $1.40 \mathrm{E}+08$ & 0.500 & 0.10 & $1.49 E+08$ & 0.500 & 1.500 & \\
\hline 24 & 0.49 & $8.23 E+08$ & $9.55 \mathrm{E}+07$ & 0.000 & $1.40 \mathrm{E}+08$ & 0.500 & 0.10 & $1.49 \mathrm{E}+08$ & 0.500 & 1.500 & \\
\hline 25 & 0.49 & $8.23 \mathrm{E}+08$ & $9.55 \mathrm{E}+07$ & 0.000 & $1.40 \mathrm{E}+08$ & 0.500 & 0.10 & $1.49 \mathrm{E}+08$ & 0.500 & 1.500 & \\
\hline 26 & 0.49 & $8.23 \mathrm{E}+08$ & $9.55 \mathrm{E}+07$ & 0.000 & $1.40 \mathrm{E}+08$ & 0.500 & 0.10 & $1.49 \mathrm{E}+08$ & 0.500 & 1.500 & \\
\hline 27 & 0.49 & $8.23 \mathrm{E}+08$ & $9.55 \mathrm{E}+07$ & 0.000 & $1.40 \mathrm{E}+08$ & 0.500 & 0.10 & $1.49 \mathrm{E}+08$ & 0.500 & 1.500 & \\
\hline 28 & 0.49 & $8.23 E+08$ & $9.55 \mathrm{E}+07$ & 0.000 & $1.40 \mathrm{E}+08$ & 0.500 & 0.10 & $1.49 \mathrm{E}+08$ & 0.500 & 1.500 & \\
\hline 29 & 0.49 & $8.23 \mathrm{E}+08$ & $9.55 \mathrm{E}+07$ & 0.000 & $1.40 \mathrm{E}+08$ & 0.500 & 0.10 & $1.49 \mathrm{E}+08$ & 0.500 & 1.500 & \\
\hline 30 & 0.49 & $8.23 E+08$ & $9.55 \mathrm{E}+07$ & 0.000 & $1.40 \mathrm{E}+08$ & 0.500 & 0.10 & $1.49 \mathrm{E}+08$ & 0.500 & 1.500 & \\
\hline 31 & 0.49 & $8.23 E+08$ & $9.55 \mathrm{E}+07$ & 0.000 & $1.40 \mathrm{E}+08$ & 0.500 & 0.10 & $1.49 E+08$ & 0.500 & 1.500 & \\
\hline 32 & 0.49 & $8.23 E+08$ & $9.55 \mathrm{E}+07$ & 0.000 & $1.40 \mathrm{E}+08$ & 0.500 & 0.10 & $1.49 \mathrm{E}+08$ & 0.500 & 1.500 & \\
\hline
\end{tabular}




\begin{tabular}{|c|c|c|c|c|c|c|c|c|c|c|c|}
\hline \multicolumn{12}{|c|}{ Table 5.2 (Continued) } \\
\hline \multicolumn{12}{|c|}{ Panama Canal } \\
\hline \multirow[b]{3}{*}{$\begin{array}{l}\text { Time } \\
\text { days }\end{array}$} & \multicolumn{4}{|c|}{$\begin{array}{l}\text { Flows are based on the } \\
\text { number of lockages }\end{array}$} & 38 & & & & & & \\
\hline & \multirow[b]{2}{*}{$\begin{array}{l}\text { Salinity - } \\
\text { ML, ppt }\end{array}$} & \multirow[b]{2}{*}{\begin{tabular}{|l} 
Volume \\
cf
\end{tabular}} & \multicolumn{2}{|c|}{$\begin{array}{l}\text { Inflow from Pedro } \\
\text { Miguel Lock } \\
\text { Operation }\end{array}$} & \multicolumn{3}{|c|}{ Exchange during lift operations } & \multicolumn{3}{|c|}{$\begin{array}{c}\text { Exchange during lift } \\
\text { operations }\end{array}$} & \multirow[b]{2}{*}{$\begin{array}{l}\text { Mass of } \\
\text { salt, Ibs }\end{array}$} \\
\hline & & & Qlock, cf & $\begin{array}{l}\text { Salnity } \\
\text { ppt }\end{array}$ & Qlock, cf & \begin{tabular}{|l|} 
Phi, \\
portion \\
of lock
\end{tabular} & $\begin{array}{l}\text { Salinity - } \\
\text { lock, ppt }\end{array}$ & Qlock, fc & $\begin{array}{l}\text { Phi, } \\
\text { portion } \\
\text { of lock }\end{array}$ & $\begin{array}{l}\text { Salinity - } \\
\text { lock, ppt }\end{array}$ & \\
\hline 33 & 0.49 & $8.23 \mathrm{E}+08$ & $9.55 \mathrm{E}+07$ & 0.000 & $1.40 \mathrm{E}+08$ & 0.500 & 0.10 & $1.49 \mathrm{E}+08$ & 0.500 & 1.500 & \\
\hline 34 & 0.49 & $8.23 \mathrm{E}+08$ & $9.55 \mathrm{E}+07$ & 0.000 & $1.40 \mathrm{E}+08$ & 0.500 & 0.10 & $1.49 \mathrm{E}+08$ & 0.500 & 1.500 & \\
\hline 35 & 0.50 & $8.23 \mathrm{E}+08$ & $9.55 \mathrm{E}+07$ & 0.000 & $1.40 \mathrm{E}+08$ & 0.500 & 0.10 & $1.49 \mathrm{E}+08$ & 0.500 & 1.500 & \\
\hline 36 & 0.50 & $8.23 \mathrm{E}+08$ & $9.55 \mathrm{E}+07$ & 0.000 & $1.40 \mathrm{E}+08$ & 0.500 & 0.10 & $1.49 \mathrm{E}+08$ & 0.500 & 1.500 & \\
\hline 37 & 0.50 & $8.23 \mathrm{E}+08$ & $9.55 \mathrm{E}+07$ & 0.000 & $1.40 \mathrm{E}+08$ & 0.500 & 0.10 & $1.49 \mathrm{E}+08$ & 0.500 & 1.500 & \\
\hline 38 & 0.50 & $8.23 \mathrm{E}+08$ & $9.55 \mathrm{E}+07$ & 0.000 & $1.40 \mathrm{E}+08$ & 0.500 & 0.10 & $1.49 \mathrm{E}+08$ & 0.500 & 1.500 & \\
\hline 39 & 0.50 & $8.23 \mathrm{E}+08$ & $9.55 \mathrm{E}+07$ & 0.000 & $1.40 \mathrm{E}+08$ & 0.500 & 0.10 & $1.49 \mathrm{E}+08$ & 0.500 & 1.500 & \\
\hline 40 & 0.50 & $8.23 \mathrm{E}+08$ & $9.55 \mathrm{E}+07$ & 0.000 & $1.40 \mathrm{E}+08$ & 0.500 & 0.10 & $1.49 \mathrm{E}+08$ & 0.500 & 1.500 & \\
\hline 41 & 0.50 & $8.23 \mathrm{E}+08$ & $9.55 \mathrm{E}+07$ & 0.000 & $1.40 \mathrm{E}+08$ & 0.500 & 0.10 & $1.49 \mathrm{E}+08$ & 0.500 & 1.500 & \\
\hline 42 & 0.50 & $8.23 \mathrm{E}+08$ & $9.55 \mathrm{E}+07$ & 0.000 & $1.40 \mathrm{E}+08$ & 0.500 & 0.10 & $1.49 \mathrm{E}+08$ & 0.500 & 1.500 & \\
\hline 43 & 0.50 & $8.23 \mathrm{E}+08$ & $9.55 \mathrm{E}+07$ & 0.000 & $1.40 \mathrm{E}+08$ & 0.500 & 0.10 & $1.49 \mathrm{E}+08$ & 0.500 & 1.500 & \\
\hline 44 & 0.50 & $8.23 E+08$ & $9.55 \mathrm{E}+07$ & 0.000 & $1.40 \mathrm{E}+08$ & 0.500 & 0.10 & $1.49 \mathrm{E}+08$ & 0.500 & 1.500 & \\
\hline 45 & 0.50 & $8.23 \mathrm{E}+08$ & $9.55 \mathrm{E}+07$ & 0.000 & $1.40 \mathrm{E}+08$ & 0.500 & 0.10 & $1.49 \mathrm{E}+08$ & 0.500 & 1.500 & \\
\hline 46 & 0.50 & $8.23 E+08$ & $9.55 \mathrm{E}+07$ & 0.000 & $1.40 \mathrm{E}+08$ & 0.500 & 0.10 & $1.49 \mathrm{E}+08$ & 0.500 & 1.500 & \\
\hline 47 & 0.50 & $8.23 E+08$ & $9.55 \mathrm{E}+07$ & 0.000 & $1.40 \mathrm{E}+08$ & 0.500 & 0.10 & $1.49 \mathrm{E}+08$ & 0.500 & 1.500 & \\
\hline 48 & 0.50 & $8.23 E+08$ & $9.55 \mathrm{E}+07$ & 0.000 & $1.40 \mathrm{E}+08$ & 0.500 & 0.10 & $1.49 \mathrm{E}+08$ & 0.500 & 1.500 & \\
\hline 49 & 0.50 & $8.23 \mathrm{E}+08$ & $9.55 \mathrm{E}+07$ & 0.000 & $1.40 \mathrm{E}+08$ & 0.500 & 0.10 & $1.49 \mathrm{E}+08$ & 0.500 & 1.500 & \\
\hline 50 & 0.50 & $8.23 \mathrm{E}+08$ & $9.55 \mathrm{E}+07$ & 0.000 & $1.40 \mathrm{E}+08$ & 0.500 & 0.10 & $1.49 \mathrm{E}+08$ & 0.500 & 1.500 & \\
\hline 51 & 0.50 & $8.23 \mathrm{E}+08$ & $9.55 \mathrm{E}+07$ & 0.000 & $1.40 \mathrm{E}+08$ & 0.500 & 0.10 & $1.49 \mathrm{E}+08$ & 0.500 & 1.500 & \\
\hline 52 & 0.50 & $8.23 \mathrm{E}+08$ & $9.55 \mathrm{E}+07$ & 0.000 & $1.40 \mathrm{E}+08$ & 0.500 & 0.10 & $1.49 \mathrm{E}+08$ & 0.500 & 1.500 & \\
\hline 53 & 0.50 & $8.23 \mathrm{E}+08$ & $9.55 \mathrm{E}+07$ & 0.000 & $1.40 \mathrm{E}+08$ & 0.500 & 0.10 & $1.49 \mathrm{E}+08$ & 0.500 & 1.500 & \\
\hline 54 & 0.50 & $8.23 \mathrm{E}+08$ & $9.55 \mathrm{E}+07$ & 0.000 & $1.40 \mathrm{E}+08$ & 0.500 & 0.10 & $1.49 \mathrm{E}+08$ & 0.500 & 1.500 & \\
\hline 55 & 0.50 & $8.23 \mathrm{E}+08$ & $9.55 \mathrm{E}+07$ & 0.000 & $1.40 \mathrm{E}+08$ & 0.500 & 0.10 & $1.49 \mathrm{E}+08$ & 0.500 & 1.500 & \\
\hline 56 & 0.50 & $8.23 \mathrm{E}+08$ & $9.55 \mathrm{E}+07$ & 0.000 & $1.40 \mathrm{E}+08$ & 0.500 & 0.10 & $1.49 \mathrm{E}+08$ & 0.500 & 1.500 & \\
\hline 57 & 0.50 & $8.23 E+08$ & $9.55 \mathrm{E}+07$ & 0.000 & $1.40 \mathrm{E}+08$ & 0.500 & 0.10 & $1.49 \mathrm{E}+08$ & 0.500 & 1.500 & \\
\hline 58 & 0.50 & $8.23 E+08$ & $9.55 \mathrm{E}+07$ & 0.000 & $1.40 \mathrm{E}+08$ & 0.500 & 0.10 & $1.49 \mathrm{E}+08$ & 0.500 & 1.500 & \\
\hline 59 & 0.50 & $8.23 \mathrm{E}+08$ & $9.55 \mathrm{E}+0$ & 0.000 & $1.40 \mathrm{E}+$ & 0.500 & 0.10 & $1.49 \mathrm{E}+08$ & 0.500 & 1.500 & \\
\hline 60 & 0.50 & $8.23 E+08$ & $9.55 \mathrm{E}+0$ & 0.000 & $1.40 \mathrm{E}+$ & 0.500 & 0.10 & $1.49 \mathrm{E}+08$ & 0.500 & 1.500 & \\
\hline 61 & 0.50 & $8.23 \mathrm{E}+08$ & $9.55 \mathrm{E}+0$ & 0.000 & $1.40 \mathrm{E}+$ & 0.500 & 0.10 & $1.49 \mathrm{E}+08$ & 0.500 & 1.500 & \\
\hline 62 & 0.50 & $8.23 \mathrm{E}+08$ & $9.55 \mathrm{E}+0$ & 0.000 & $1.40 \mathrm{E}+$ & 0.500 & 0.10 & $1.49 \mathrm{E}+08$ & 0.500 & 1.500 & \\
\hline 63 & 0.50 & $8.23 \mathrm{E}+08$ & $9.55 \mathrm{E}+0$ & 0.000 & $1.40 \mathrm{E}+$ & 0.500 & 0.10 & $1.49 \mathrm{E}+08$ & 0.500 & 1.500 & \\
\hline 64 & 0.50 & $8.23 E+08$ & $9.55 \mathrm{E}+0$ & 0.000 & $1.40 \mathrm{E}+$ & 0.500 & 0.10 & $1.49 \mathrm{E}+08$ & 0.500 & 1.500 & \\
\hline
\end{tabular}




\begin{tabular}{|c|c|c|c|c|c|c|c|c|c|c|c|}
\hline \multicolumn{12}{|c|}{ Table 5.2 (Concluded) } \\
\hline \multicolumn{12}{|c|}{ Panama Canal } \\
\hline \multirow[b]{3}{*}{$\begin{array}{l}\text { Time } \\
\text { days }\end{array}$} & \multirow[b]{3}{*}{$\begin{array}{l}\text { Salinity - } \\
\text { ML, ppt }\end{array}$} & \multicolumn{3}{|c|}{$\begin{array}{l}\text { Flows are based on the } \\
\text { number of lockages }\end{array}$} & \multirow{2}{*}{\multicolumn{3}{|c|}{ Exchange during lift operations }} & \multirow{2}{*}{\multicolumn{3}{|c|}{$\begin{array}{l}\text { Exchange during lift } \\
\text { operations }\end{array}$}} & \multirow[b]{3}{*}{$\begin{array}{l}\text { Mass of } \\
\text { salt, lbs }\end{array}$} \\
\hline & & \multirow[b]{2}{*}{$\begin{array}{l}\text { Volume } \\
\text { cf }\end{array}$} & \multicolumn{2}{|c|}{$\begin{array}{l}\text { Inflow from Pedro } \\
\text { Miguel Lock } \\
\text { Operation }\end{array}$} & & & & & & & \\
\hline & & & Qlock, cf & $\begin{array}{l}\text { Salnity } \\
\text { ppt }\end{array}$ & Qlock, cf & \begin{tabular}{|l|} 
Phi, \\
portion \\
of lock
\end{tabular} & $\begin{array}{l}\text { Salinity - } \\
\text { lock, ppt }\end{array}$ & Qlock, fc & \begin{tabular}{|l|} 
Phi, \\
portion \\
of lock
\end{tabular} & $\begin{array}{l}\text { Salinity - } \\
\text { lock, ppt }\end{array}$ & \\
\hline 65 & 0.50 & $8.23 \mathrm{E}+08$ & $9.55 \mathrm{E}+0$ & 0.000 & $1.40 \mathrm{E}+$ & 0.500 & 0.10 & $1.49 \mathrm{E}+08$ & 0.500 & 1.500 & \\
\hline 66 & 0.50 & $8.23 \mathrm{E}+08$ & $9.55 \mathrm{E}+0$ & 0.000 & $1.40 \mathrm{E}+$ & 0.500 & 0.10 & $1.49 \mathrm{E}+08$ & 0.500 & 1.500 & \\
\hline 67 & 0.50 & $8.23 \mathrm{E}+08$ & $9.55 \mathrm{E}+0$ & 0.000 & $1.40 \mathrm{E}_{+}$ & 0.500 & 0.10 & $1.49 \mathrm{E}+08$ & 0.500 & 1.500 & \\
\hline 68 & 0.50 & $8.23 E+08$ & $9.55 \mathrm{E}+0$ & 0.000 & $1.40 \mathrm{E}_{+}$ & 0.500 & 0.10 & $1.49 \mathrm{E}+08$ & 0.500 & 1.500 & \\
\hline 69 & 0.50 & $8.23 E+08$ & $9.55 \mathrm{E}+0$ & 0.000 & $1.40 \mathrm{E}_{+}$ & 0.500 & 0.10 & $1.49 \mathrm{E}+08$ & 0.500 & 1.500 & \\
\hline 70 & 0.50 & $8.23 \mathrm{E}+08$ & $9.55 \mathrm{E}+0$ & 0.000 & $1.40 \mathrm{E}_{+}$ & 0.500 & 0.10 & $1.49 \mathrm{E}+08$ & 0.500 & 1.500 & \\
\hline 71 & 0.50 & $8.23 E+08$ & $9.55 \mathrm{E}+0$ & 0.000 & $1.40 \mathrm{E}+$ & 0.500 & 0.10 & $1.49 \mathrm{E}+08$ & 0.500 & 1.500 & \\
\hline 72 & 0.50 & $8.23 E+08$ & $9.55 \mathrm{E}+0$ & 0.000 & $1.40 \mathrm{E}_{+}$ & 0.500 & 0.10 & $1.49 \mathrm{E}+08$ & 0.500 & 1.500 & \\
\hline 73 & 0.50 & $8.23 \mathrm{E}+08$ & $9.55 \mathrm{E}+0$ & 0.000 & $1.40 \mathrm{E}+$ & 0.500 & 0.10 & $1.49 \mathrm{E}+08$ & 0.500 & 1.500 & \\
\hline 74 & 0.50 & $8.23 \mathrm{E}+08$ & $9.55 \mathrm{E}+0$ & 0.000 & $1.40 \mathrm{E}_{+}$ & 0.500 & 0.10 & $1.49 \mathrm{E}+08$ & 0.500 & 1.500 & \\
\hline 75 & 0.50 & $8.23 \mathrm{E}+08$ & $9.55 \mathrm{E}+0$ & 0.000 & $1.40 \mathrm{E}+$ & 0.500 & 0.10 & $1.49 \mathrm{E}+08$ & 0.500 & 1.500 & \\
\hline 76 & 0.50 & $8.23 E+08$ & $9.55 \mathrm{E}+0$ & 0.000 & $1.40 \mathrm{E}_{+}$ & 0.500 & 0.10 & $1.49 \mathrm{E}+08$ & 0.500 & 1.500 & \\
\hline 77 & 0.50 & $8.23 E+08$ & $9.55 \mathrm{E}+0$ & 0.000 & $1.40 \mathrm{E}+$ & 0.500 & 0.10 & $1.49 \mathrm{E}+08$ & 0.500 & 1.500 & \\
\hline 78 & 0.50 & $8.23 \mathrm{E}+08$ & $9.55 \mathrm{E}+0$ & 0.000 & $1.40 \mathrm{E}_{+}$ & 0.500 & 0.10 & $1.49 \mathrm{E}+08$ & 0.500 & 1.500 & \\
\hline 79 & 0.50 & $8.23 E+08$ & $9.55 \mathrm{E}+0$ & 0.000 & $1.40 \mathrm{E}+$ & 0.500 & 0.10 & $1.49 \mathrm{E}+08$ & 0.500 & 1.500 & \\
\hline 80 & 0.50 & $8.23 \mathrm{E}+08$ & $9.55 \mathrm{E}+0$ & 0.000 & $1.40 \mathrm{E}_{+}$ & 0.500 & 0.10 & $1.49 \mathrm{E}+08$ & 0.500 & 1.500 & \\
\hline 81 & 0.50 & $8.23 E+08$ & $9.55 \mathrm{E}+0$ & 0.000 & $1.40 \mathrm{E}+$ & 0.500 & 0.10 & $1.49 \mathrm{E}+08$ & 0.500 & 1.500 & \\
\hline 82 & 0.50 & $8.23 \mathrm{E}+08$ & $9.55 \mathrm{E}+0$ & 0.000 & $1.40 \mathrm{E}_{+}$ & 0.500 & 0.10 & $1.49 \mathrm{E}+08$ & 0.500 & 1.500 & \\
\hline 83 & 0.50 & $8.23 E+08$ & $9.55 \mathrm{E}+0$ & 0.000 & $1.40 \mathrm{E}+$ & 0.500 & 0.10 & $1.49 \mathrm{E}+08$ & 0.500 & 1.500 & \\
\hline 84 & 0.50 & $8.23 E+08$ & $9.55 \mathrm{E}+0$ & 0.000 & $1.40 \mathrm{E}+$ & 0.500 & 0.10 & $1.49 \mathrm{E}+08$ & 0.500 & 1.500 & \\
\hline 85 & 0.50 & $8.23 E+08$ & $9.55 \mathrm{E}+0$ & 0.000 & $1.40 \mathrm{E}+$ & 0.500 & 0.10 & $1.49 \mathrm{E}+08$ & 0.500 & 1.500 & \\
\hline 86 & 0.50 & $8.23 E+08$ & $9.55 \mathrm{E}+0$ & 0.000 & $1.40 \mathrm{E}+$ & 0.500 & 0.10 & $1.49 \mathrm{E}+08$ & 0.500 & 1.500 & \\
\hline 87 & 0.50 & $8.23 E+08$ & $9.55 \mathrm{E}+0$ & 0.000 & $1.40 \mathrm{E}+$ & 0.500 & 0.10 & $1.49 \mathrm{E}+08$ & 0.500 & 1.500 & \\
\hline 88 & 0.50 & $8.23 \mathrm{E}+08$ & $9.55 \mathrm{E}+0$ & 0.000 & $1.40 \mathrm{E}+$ & 0.500 & 0.10 & $1.49 \mathrm{E}+08$ & 0.500 & 1.500 & \\
\hline 89 & 0.50 & $8.23 E+08$ & $9.55 \mathrm{E}+0$ & 0.000 & $1.40 \mathrm{E}+$ & 0.500 & 0.10 & $1.49 \mathrm{E}+08$ & 0.500 & 1.500 & \\
\hline 90 & 0.50 & $8.23 E+08$ & $9.55 \mathrm{E}+0$ & 0.000 & $1.40 \mathrm{E}+$ & 0.500 & 0.10 & $1.49 \mathrm{E}+08$ & 0.500 & 1.500 & \\
\hline 91 & 0.50 & $8.23 \mathrm{E}+08$ & $9.55 \mathrm{E}+0$ & 0.000 & $1.40 \mathrm{E}+$ & 0.500 & 0.10 & $1.49 \mathrm{E}+08$ & 0.500 & 1.500 & \\
\hline 92 & 0.50 & $8.23 E+08$ & $9.55 \mathrm{E}+0$ & 0.000 & $1.40 \mathrm{E}_{+}$ & 0.500 & 0.10 & $1.49 \mathrm{E}+08$ & 0.500 & 1.500 & \\
\hline 93 & 0.50 & $8.23 E+08$ & $9.55 \mathrm{E}+0$ & 0.000 & $1.40 \mathrm{E}+$ & 0.500 & 0.10 & $1.49 \mathrm{E}+08$ & 0.500 & 1.500 & \\
\hline 94 & 0.50 & $8.23 \mathrm{E}+08$ & $9.55 \mathrm{E}+0$ & 0.000 & $1.40 \mathrm{E}+$ & 0.500 & 0.10 & $1.49 \mathrm{E}+08$ & 0.500 & 1.500 & \\
\hline 95 & 0.50 & $8.23 \mathrm{E}+08$ & $9.55 \mathrm{E}+0$ & 0.000 & $1.40 \mathrm{E}+$ & 0.500 & 0.10 & $1.49 \mathrm{E}+08$ & 0.500 & 1.500 & \\
\hline 96 & 0.50 & $8.23 \mathrm{E}+08$ & $9.55 \mathrm{E}+0$ & 0.000 & $1.40 \mathrm{E}_{+}$ & 0.500 & 0.10 & $1.49 \mathrm{E}+08$ & 0.500 & 1.500 & \\
\hline 97 & 0.50 & $8.23 E+08$ & $9.55 \mathrm{E}+0$ & 0.000 & $1.40 \mathrm{E}+$ & 0.500 & 0.10 & $1.49 \mathrm{E}+08$ & 0.500 & 1.500 & \\
\hline 98 & 0.50 & $8.23 \mathrm{E}+08$ & $9.55 \mathrm{E}+0$ & 0.000 & $1.40 \mathrm{E}_{+}$ & 0.500 & 0.10 & $1.49 \mathrm{E}+08$ & 0.500 & 1.500 & \\
\hline 99 & 0.50 & $8.23 \mathrm{E}+08$ & $9.55 \mathrm{E}+0$ & 0.000 & $1.40 \mathrm{E}+$ & 0.500 & 0.10 & $1.49 \mathrm{E}+08$ & 0.500 & 1.500 & \\
\hline 100 & 0.50 & $8.23 E+08$ & $9.55 \mathrm{E}+0$ & 0.000 & $1.40 \mathrm{E}+$ & 0.500 & 0.10 & $1.49 \mathrm{E}+08$ & 0.500 & 1.500 & \\
\hline
\end{tabular}




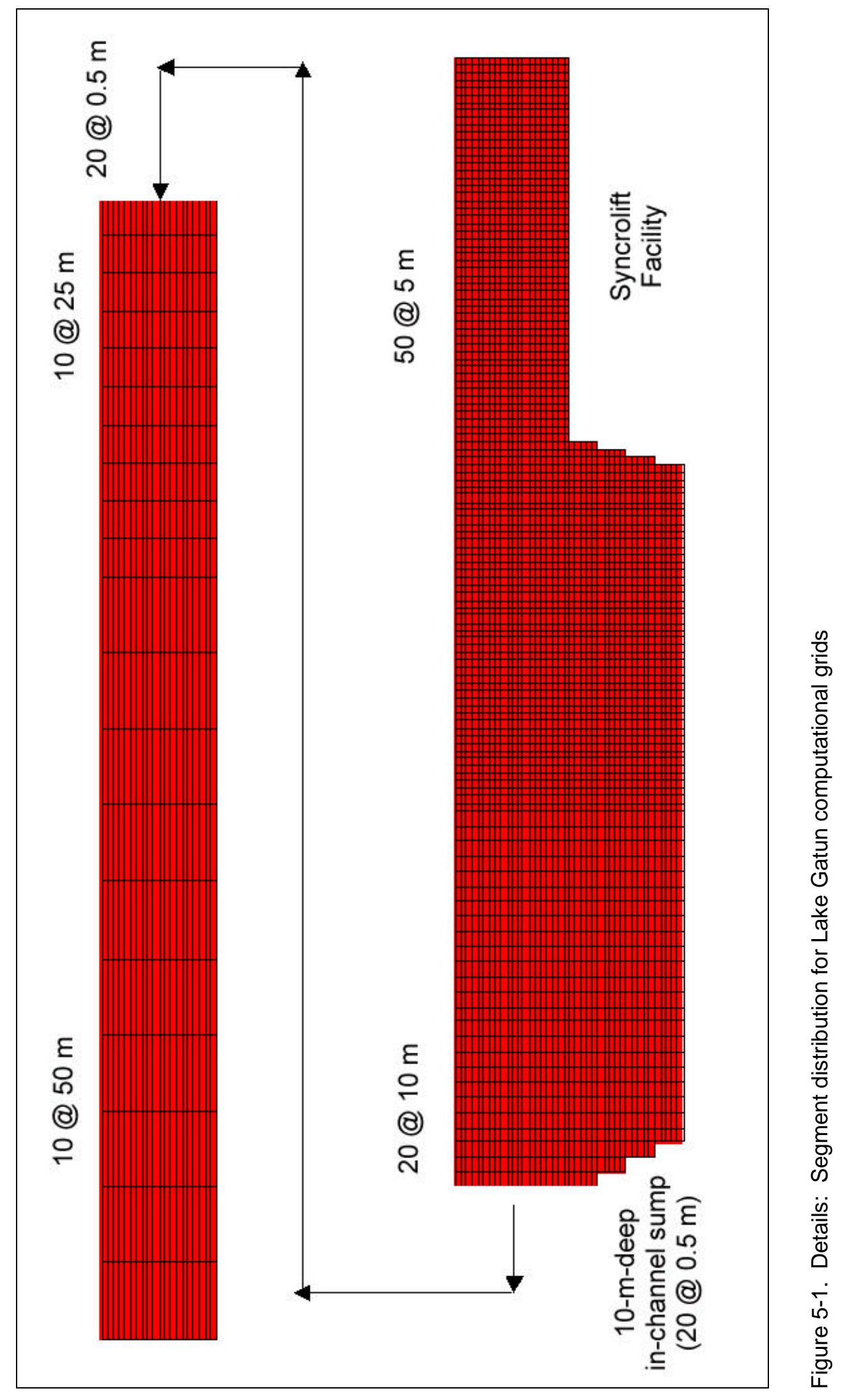




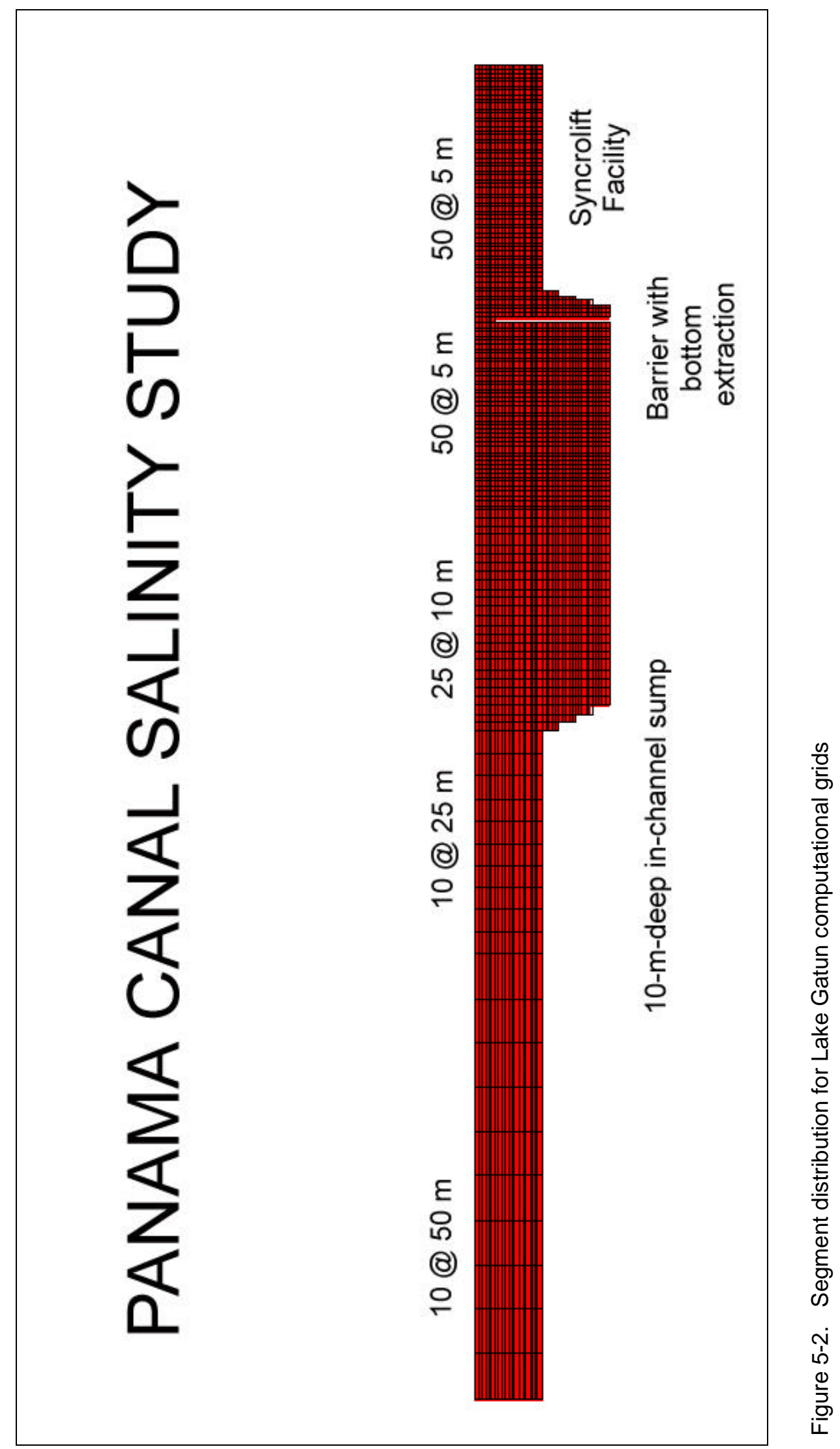




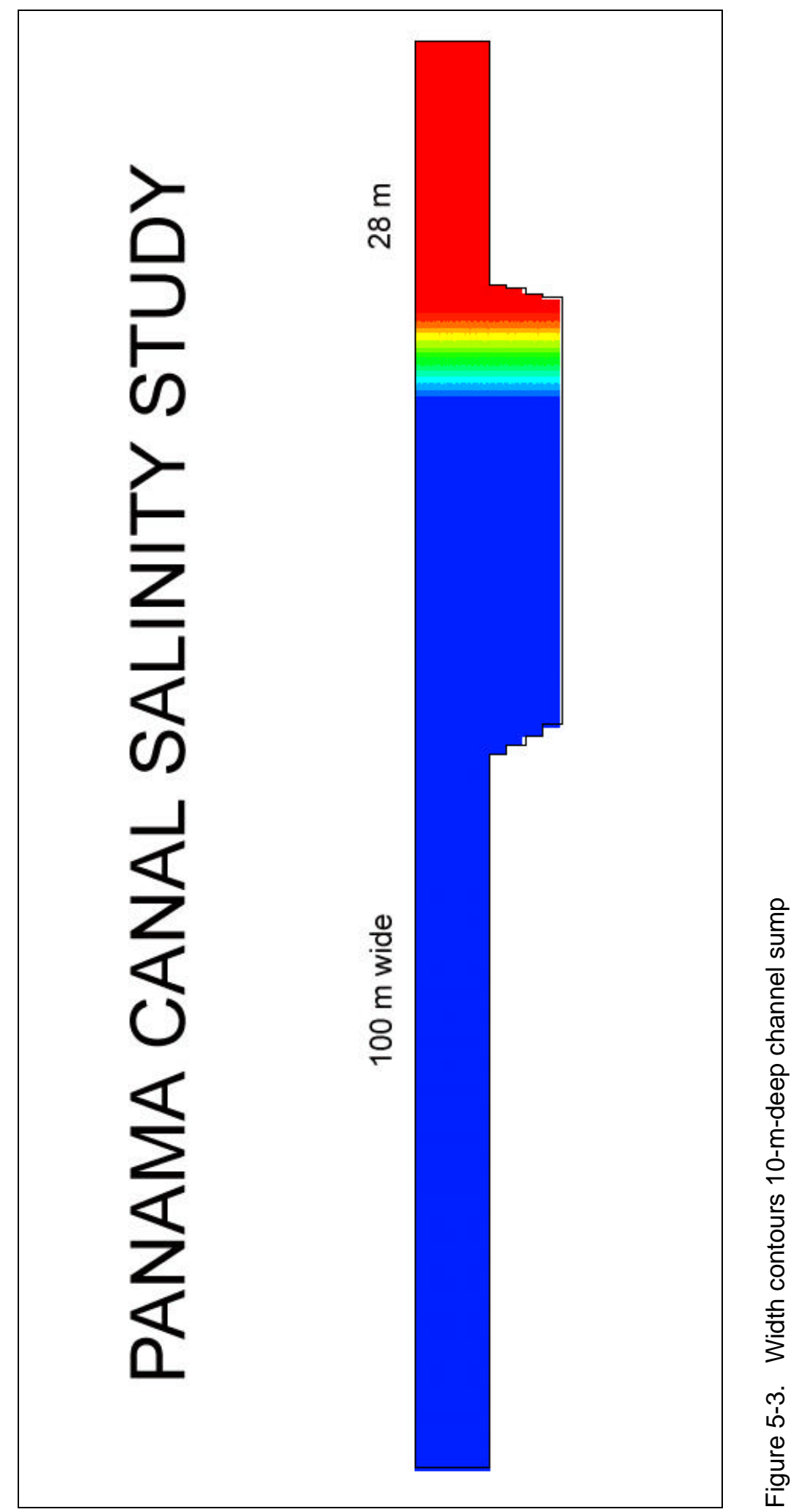




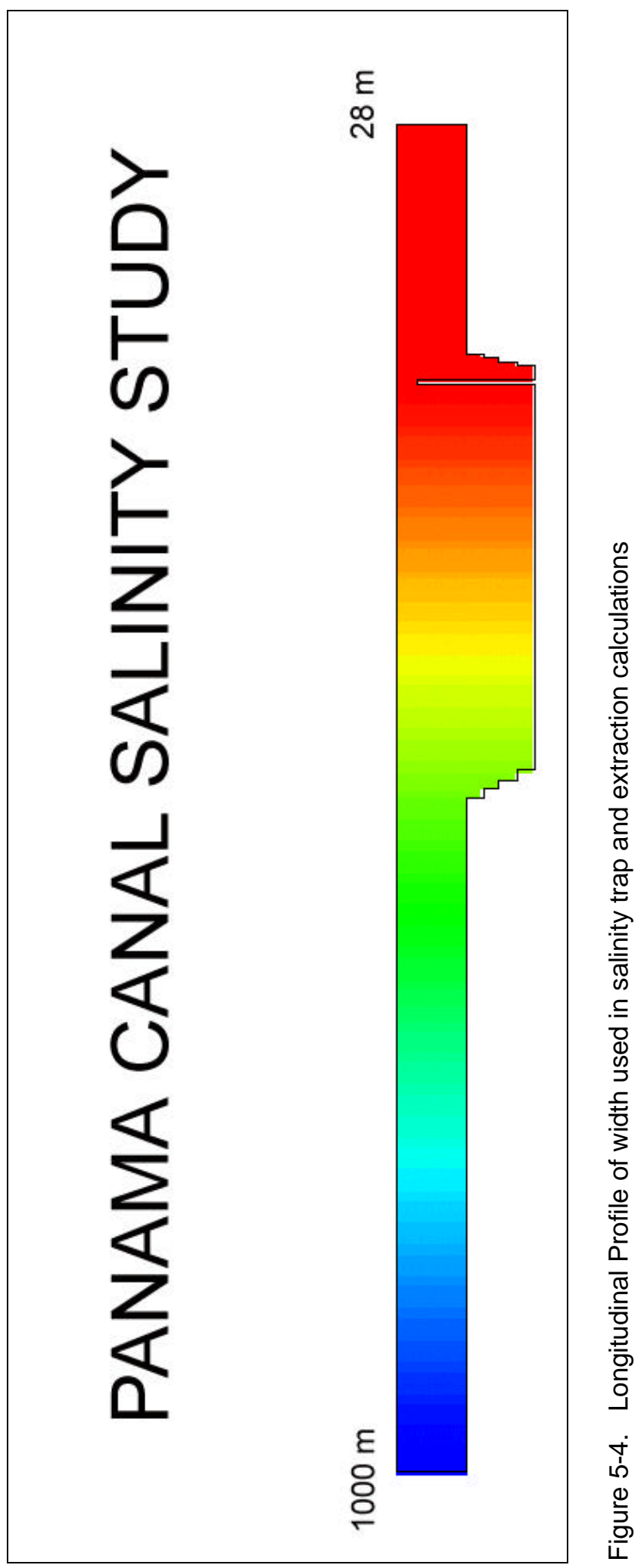




\section{Modeling Salt Movement Across Gatun Lake}

\section{Objective}

The objective of this portion of the work is to examine how salinity moves into Gatun Lake from the locks if the salt water is not captured immediately in front of the lock. The results will help Canal managers compare capacity expansion and fresh water conservation plans and to assess the need for remedial measures to maintain the desired salinity level across the lake.

\section{Models and Assumptions}

The hydrodynamics of Gatun Lake were modeled in two dimensions by using the TABS-MD numerical modeling system of the U.S. Army Corps of Engineers. TABS-MD consists of a number of computer-based numerical models for open-channel flow and transport. For the effort described here, the depthaveraged two-dimensional hydrodynamic model RMA-2 and companion transport model RMA-4 were used. RMA-2 provides a finite element solution of the Reynolds form of the two-dimensional, constant density Navier-Stokes equations for turbulent open channel flows. RMA-4 solves the two-dimensional advection-diffusion equation for multiple dissolved constituents. (See Appendix D for discussion of the governing equations and assumptions.)

Salinity flow out of the locks will have a significant three-dimensional density-driven structure that will be fully captured only by a three-dimensional model that has been verified to field observations. However, the objectives of this effort can be met by application of two-dimensional models as described in this section and the preceding section of this report. The two-dimensional widthaveraged numerical model of Part 5 accurately depicts the density-driven vertical flow structure near the lock, and the depth-averaged results presented in this section will be more accurate farther from the locks, where diffusive transport dominates, and where the waterway is much wider. The models used here have not been verified to field observations, but the calculations are physics-based and have been applied to many sites by the Corps of Engineers and others (Heath et al., 1999) so the results are considered qualitatively reliable and quantitatively 
useful when one set of model far-field results is compared with another, e.g., existing conditions versus the Syncrolift plan and wet versus dry season..

For the purposes of this study, a mesh representing Gatun Lake and the Panama Canal with its Atlantic and Pacific entrances was developed (See Figure 6-1). This mesh, constructed using maps provided by the Panama Canal Commission, was employed by RMA-2 and RMA-4 to solve the governing equations across the area of interest. Elevations of the lake bottom are shown by shading in Figure 6-1.

\section{Experimental Conditions}

The hydrodynamic calculations assumed that 38 lockage operations occur per day at both Atlantic and Pacific entrances; thus, boundary rating curves were applied at both entrances to provide outflows equal to the lift volume required to execute that many lockages. These curves remove water from the lake by taking into account the volume of the lock and the water surface elevation in the vicinity of the lock at the time. Outflows over the spillways were specified as zero during the dry season and were calculated from water surface elevations during the wet season. Fresh water inflows to the system were applied at four locations: Madden Lake, Gatun River at Ciento, Ciri Grande River at Los Cañones, and Trinidad River at El Chorro. Evaporation was considered, as well as possible outflows from the lake for municipal uses and power generation. Model runs were performed for a two month period, which was sufficient to reach a quasisteady-state condition.

The existing conditions were evaluated for two seasons, wet and dry. During dry season, which lasts approximately 5 to 6 months out of the year, the inflows at the locations mentioned above are significantly lower than those present during wet season. As a result, the Gatun Dam spillway does not operate during this time. On the other hand, the wet season inflows are up to 4 times larger than the dry season, thereby increasing the water surface elevation of the lake and opening the spillway for operation. For the modeling process, Gatun Lake was kept at a water surface elevation of $26 \mathrm{~m}$ ( 85 feet) during dry season and at $27 \mathrm{~m}$ (87.5 feet) for wet season.

Based on field observations and the calculations shown in Part 3 and Appendix A, a salinity of 0.083 ppt was applied as a boundary condition at the Gatun Dam locks. Likewise, a salinity value of 0.13 was applied as the boundary condition at the Pedro Miguel Locks. For the Syncrolift lock plan, a unit concentration was specified at the lock location. Since the depth-integrated model does not calculate water density and density currents, this unit concentration can be approximately any specified salinity in the lock by simply multiplying the model results by the specified lock concentration. The existing lock results may be similarly extended to other in-lock concentrations by a ratio of the specified concentration to the values listed above. Extending these results to other lock salinities and comparing the syncrolift tracer results to existing lock results is only approximate, since diffusion rate in the model is proportional to 
the concentration gradient. Thus, more rapid initial diffusion will be computed for the $1.0 \mathrm{ppt}$ lock condition than for the $0.08 \mathrm{ppt}$ lock condition.

\section{Plans Tested}

Two lock configurations - the existing locks and an additional lock (Syncrolift) adjacent to each set of locks - and two hydrologic conditions - wet and dry seasons - were examined. In summary, four model runs were made:

a. Existing conditions during dry season

$b$. Existing conditions during wet season.

c. Syncrolift lock (only) at both entrances during dry season.

d. Syncrolift lock (only) at both entrances during wet season.

\section{Results}

Figure 6-2 shows a snap-shot comparison of wet and dry seasons for existing conditions in the vicinity of the Pedro Miguel Locks after two months. The dry season permits salinity to intrude much further than the wet season, and salinity contours are seen to intrude nearly to Madden Lake. However, during the wet season the salt is swept back to the locks and out via the spillway.

Figure 6-3 shows a comparison between wet and dry seasons at the Atlantic side of Gatun Lake. As seen in the figure, salinity concentrations remain higher on this side more readily during wet season, since the salt is not confined in a narrow channel as on the Pacific side. Nevertheless, salinity values do not exceed $0.027 \mathrm{ppt}$ inside the lake even in the worst case, which corresponds to the lack of observed salinity buildup in Gatun Lake. The Gatun spillway is seen to play a key role during wet season in removing higher salinity water from the lake, for the low concentration plume is drawn to the spillway.

Similar scenarios play out when adding the Syncrolift locks to the system. Figure 6-4 portrays how tracer in the Syncrolift locks diffuses from the Pedro Miguel Locks for wet and dry seasons. The contours on Figures 6-4 and 6-5 show the fraction of the initial lock concentration present in different areas of the mesh after the model has run for two months.

Figure 6-5 shows a closer look at the Gatun Locks area, where we again see that the Gatun spillway is important in alleviating salinity concentrations during the wet season. We should note, though, that the increased tracer concentrations observed in the vicinity of the Gatun Locks during dry season are mostly a product of tracer diffusing up through the lake from the Pedro Miguel Locks. Film loops accompanying this report show this situation clearly. 


\section{Recommendations for Design Phase}

This modeling approach depicts what happens to salt that is not captured close to the locks. If the final design for expanding canal capacity ensures that no more salt water will be released from the locks than under existing conditions, Gatun Lake need not be modeled during the design phase. However, this modeling approach, either in two-dimensions or three-dimensions, can be used to predict salinities in the waterways at the sea ends of both locks to improve the boundary conditions assumed in Part 3 of this report.

If Gatun Lake transport is modeled in the design phase, the threedimensional version of these models (TABS-10) should be used to ensure that densimetric transport is reproduced. The model should be verified to field measurements of current speed and direction and salinity, with low-threshold instruments employed to successfully measure the small flow speeds and salinities of the lake. 


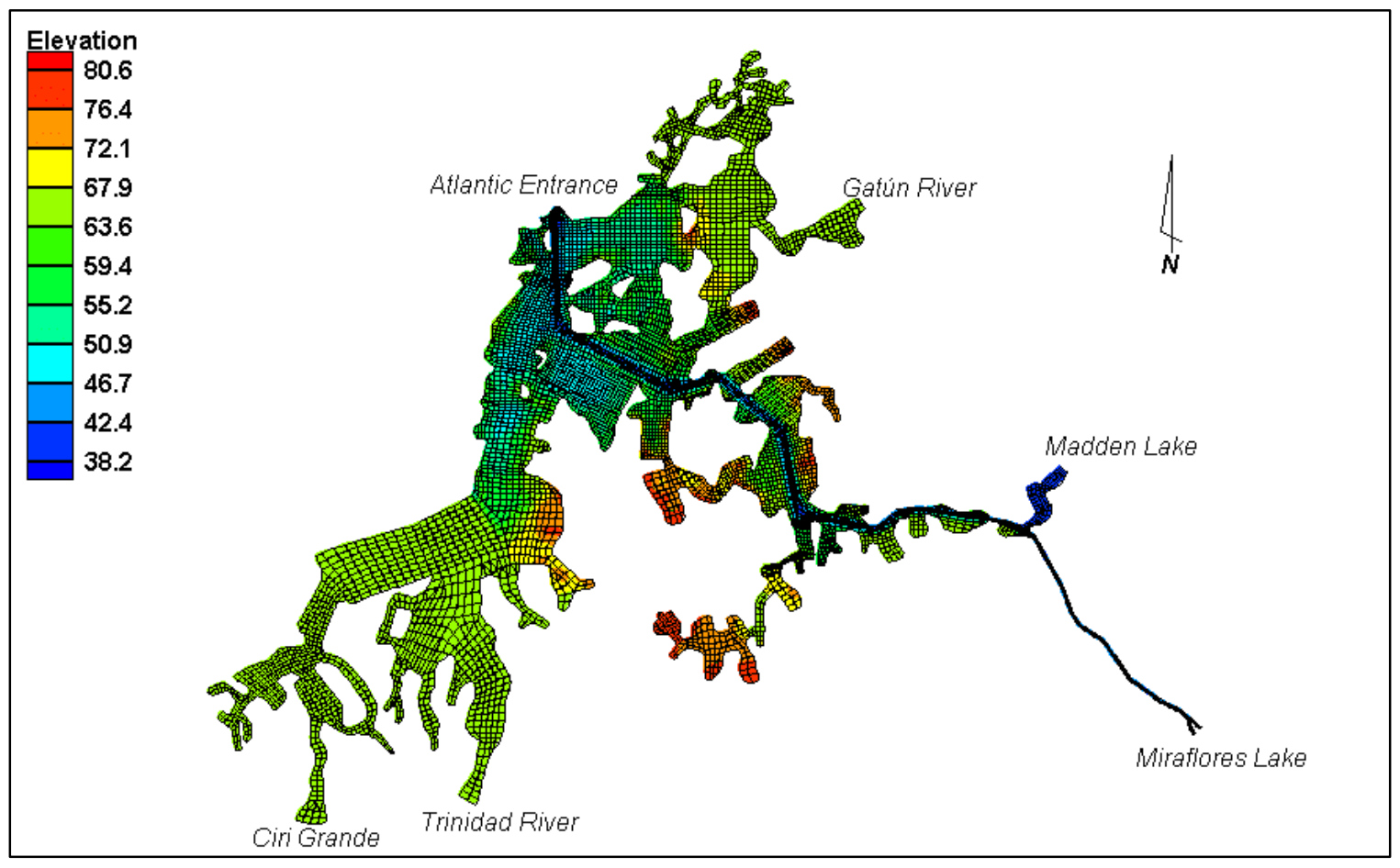

Figure 6-1. Depth-integrated model computational mesh of Gatun Lake and Panama Canal. Shaded areas indicate bottom elevation of lake in feet 


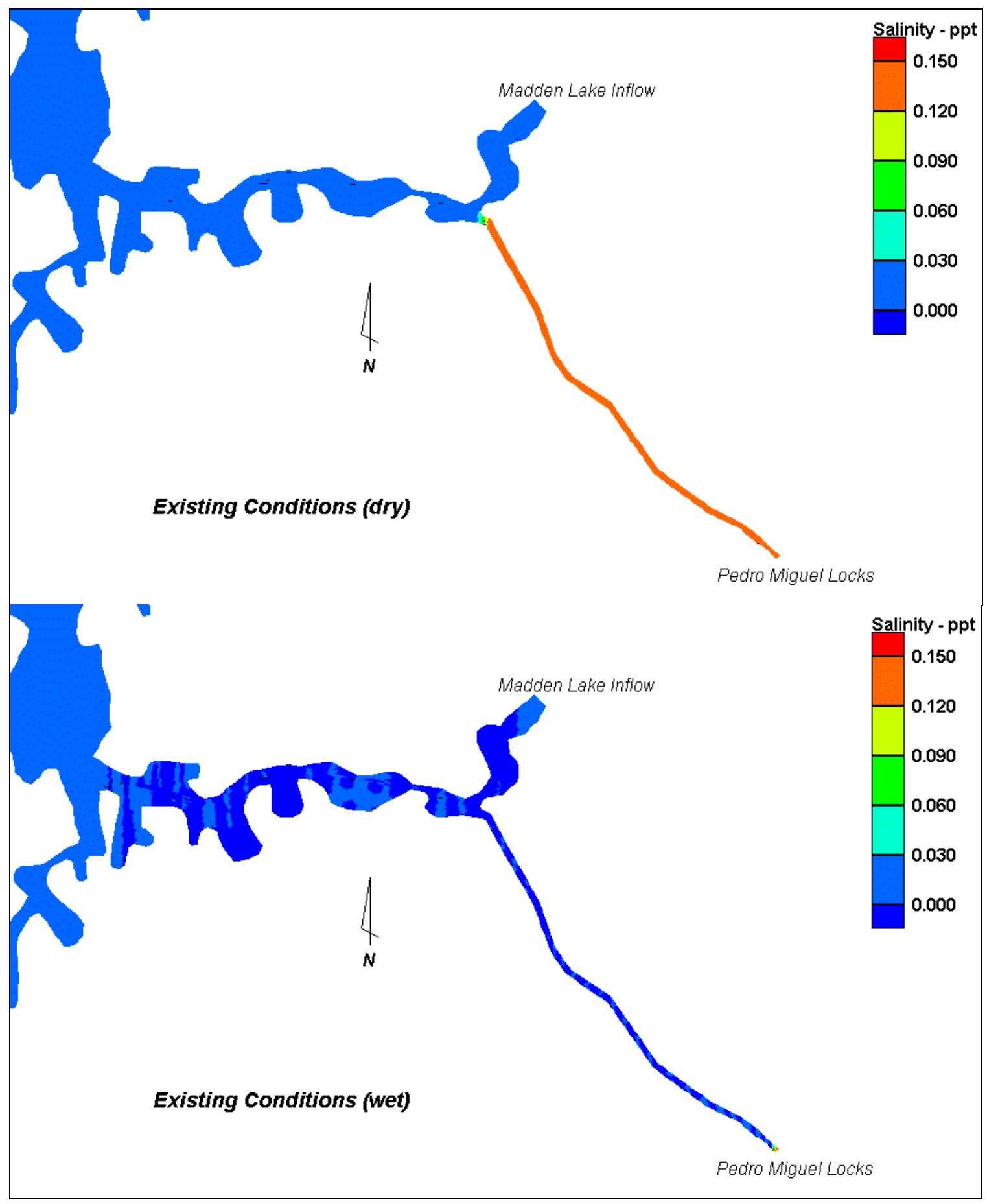

Figure 6-2. Salinity Profiles at Pedro Miguel Locks and Surrounding Areas for dry and wet seasons 


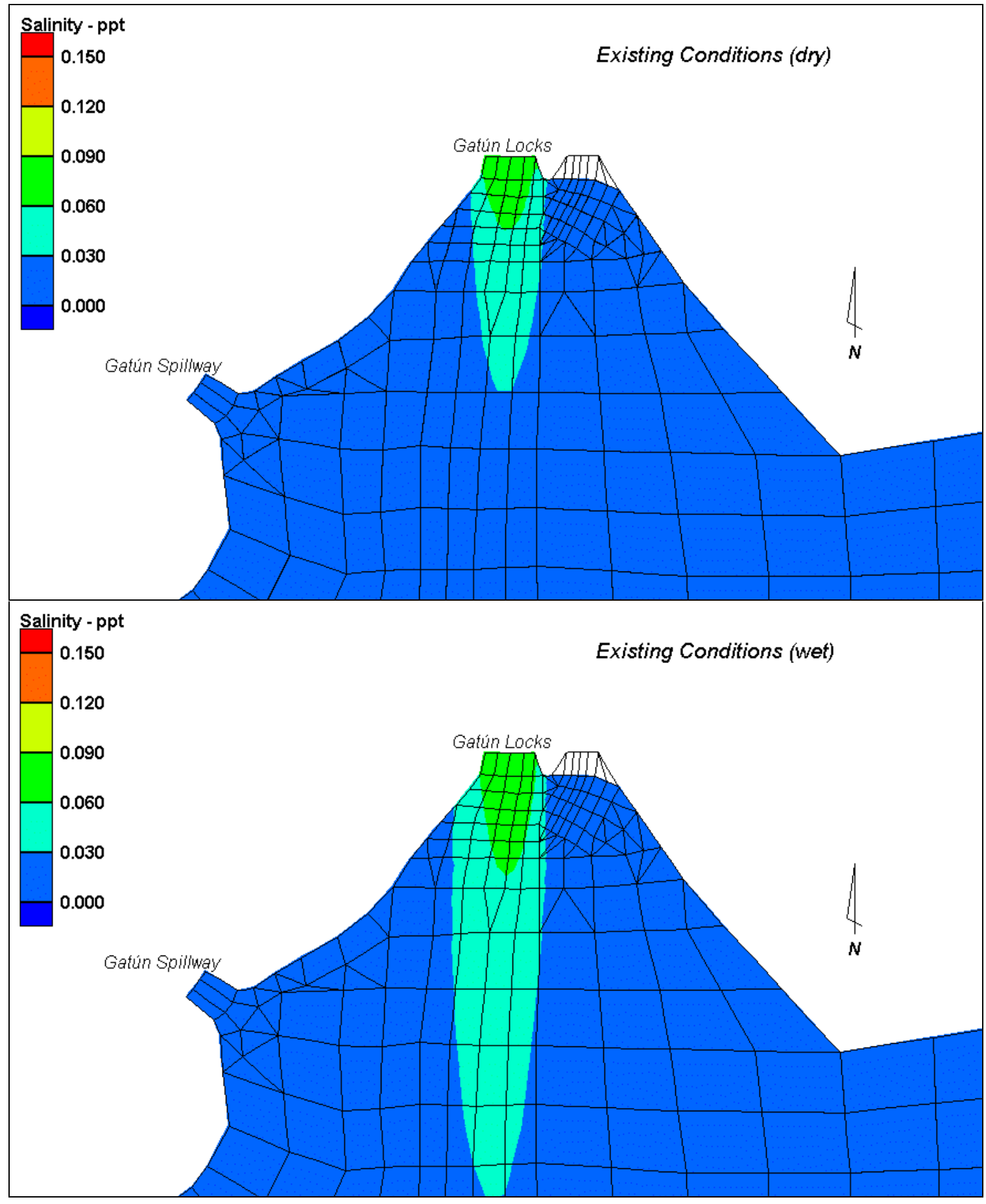

Figure 6-3. Salinity patterns near Gatun Locks for dry and wet seasons 


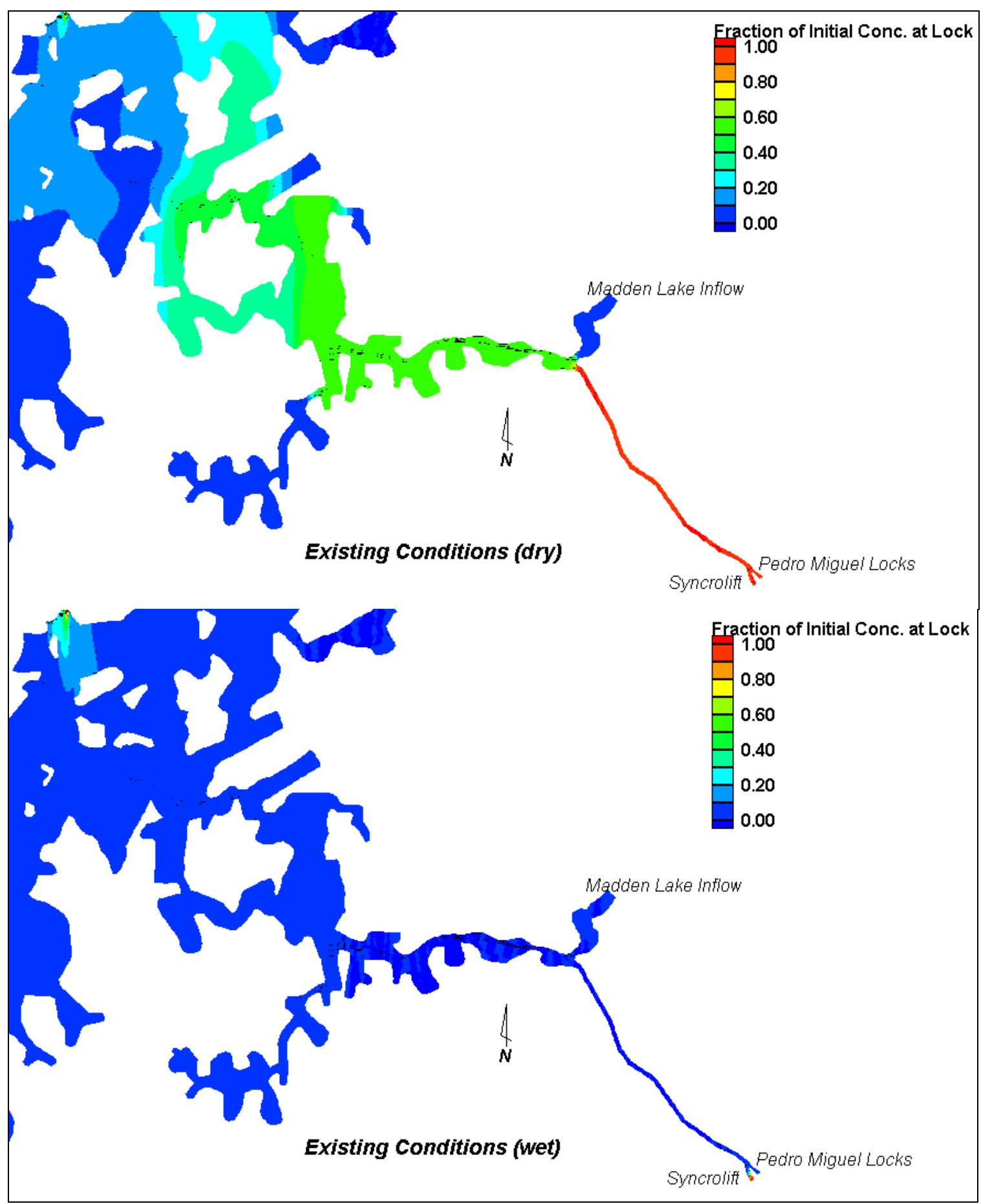

Figure 6-4. Concentration patterns for the Syncrolift lock plan in dry and wet seasons 


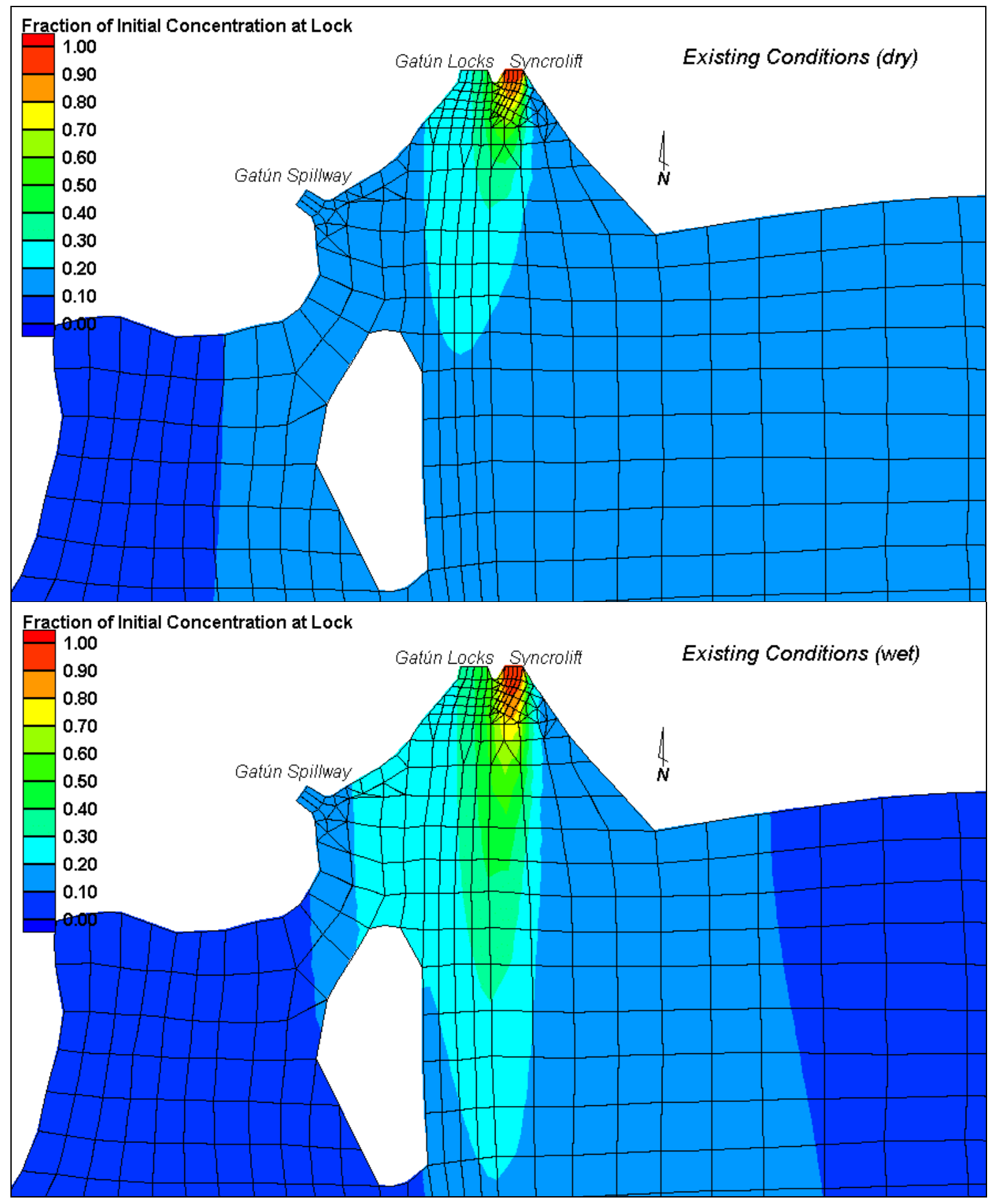

Figure 6-5. Concentration patterns at Gatun Locks for dry and wet seasons with both existing locks and Syncrolift in operation 


\section{Summary and Conclusions}

A review of salinity control measures at locks worldwide shows a variety of methods being employed, including salt water barriers, sumps to collect and drain salty water, and mixing devices to limit intrusion. A detailed evaluation of the Hiram Chittenden Locks in Seattle, Washington, USA, shows that a salt water sump with a hinged barrier is an effective approach to salt water intrusion control.

Salt water is slightly more dense than freshwater, causing it to flow under fresh water in a density current unless mixed by strong currents, ship propwash, or artificial mixing devices such as bubble screens. Density currents may lead to greater saltwater intrusion than would occur in well-mixed waters, but offers an opportunity to capture some of the salt water before it intrudes into the freshwater zone upstream of the locks.

A set of tools has been developed that supports evaluation of salinity intrusion and freshwater consumption through the Panama Canal locks for Gatun Lake. They include:

a. A simple mixing analysis coded in spreadsheet form that provides zerodimensional models for the salinity of individual locks and for Miraflores Lake and Gatun Lake plus a freshwater consumption model for Gatun Lake.

$b$. A depth-integrated two-dimensional numerical model for dispersive transport of salt water into Gatun Lake.

c. A width-integrated two-dimensional numerical model for densimetric advection and dispersion of salty water from the locks into a channel.

The numerical models employ the graphical user environment of the U. S. Army Corps of Engineers Surface Water Management System (SMS) to manage the models and display their results. The zero-dimensional models have been adjusted to yield results roughly comparable to limited field observations of salinity in the Panama Canal. The two-dimensional models are physics-based and have been successfully employed in many applications; however, they have not been verified to field observations in Gatun Lake.

These tools have been applied in a feasibility-level evaluation of the following alternatives for expansion of Panama Canal capacity. 
a. Use of holding ponds to conserve fresh water by recirculating lift water.

$b$. Installation of a Syncrolift lock chamber adjacent to the Miraflores and Gatun Locks.

c. A sump in the channel upstream of the locks to capture more dense salty water and drain it before it reaches the lake.

d. A gated chamber upstream of the locks to hold salty water while it is drained to the sea and replaced with freshwater.

Analyses using the tools listed above show that:

a. Freshwater consumption can be reduced by up to about $60 \%$ by recirculating lift water through holding ponds, albeit at the cost of increasing salinity in the ocean approach channels and ultimately in the uppermost locks. If this option is employed, the potential for increased salinity intrusion and necessary remedial measures should be addressed.

$b$. A sump in the channel upstream of the locks can capture salt water through selective withdrawal, and is most effective for higher salinity (and thus more dense) water in the locks; however, higher salinity in the locks (now about $0.1 \mathrm{ppt}$ in the uppermost Miraflores and Gatun Locks) risks greater salinity contamination of the lake if any lock water escapes the sump. A sump requires some sort of confined channel upstream of the lock to train the densimetric flow out of the lock.

c. A salinity of greater than $0.3 \mathrm{ppt}$ in the uppermost locks, including a Syncrolift lock, risks unsatisfactory buildup of salt water in Gatun Lake unless some means of capturing most of the salt water is incorporated in the facility.

d. A gated chamber on the lake side of the uppermost lock offers the option of draining salty water from the lock and replacing it with fresh water before opening for ship passage. This technique provides positive salinity control at the locks, either standard or Syncrolift, at the cost of a delay in the vessels' exit of the lock.

\section{Recommendations}

We recommend:

a. Further consideration of recirculating lift water through holding ponds as a means of freshwater conservation.

$b$. Further consideration of a gated chamber at the uppermost lock entrance on each side to reduce salinity intrusion into Gatun Lake if either the 
Syncrolift lock or the holding pond/recirculation alternatives are considered for design.

c. Use of the tools developed here in the design phase of any canal improvement plans. They should be verified to a comprehensive field data set of water levels, velocities, salinities, and temperatures before use in a design effort.

d. Addition of a model of the sea approaches to calculate the salinity there under any alternative that might alter the salinity, such as the recirculation/holding pond option.

$e$. Field data collection in support of further modeling should be synoptic to the maximum degree possible, should include acoustic Doppler current profiling, and should include salinity meters capable of measurements to hundredths of a ppt. If field instruments are not available to meet this requirement, water samples may be collected and analyzed in a laboratory to the required accuracy. 


\section{References}

Abraham, G., and Van Der Burgh, P. (1964). Pneumatic reduction of salt intrusion through locks, Journal of Hydraulics Division, ASCE, vol. 90, No. HY1, 83-119.

Abraham, G., Van Der Burgh, P., and De Vos, P. (1973). Pneumatic barriers to reduce salt intrusion through locks, Riijkswaterstaat Communications No 17. (Also Delft Hydraulics Laboratory, the Netherlands, Publication No. 126).

Abraham, G., and Van Der Burgh, P. (1962). Reduction of salt water intrusion through locks by pneumatic barriers, Delft Hydraulics Laboratory, the Netherlands, Publication No. 28.

Abraham, G., Van Der Burgh, P., and De Vos, P. (1965). Means to reduce salt intrusion through new and existing locks, Delft Hydraulics Laboratory, the Netherlands, Publication No. 38.

Boggess D. S. (1968). A test of flushing procedures to control salt-water intrusion at the W. P. Franklin Dam near Ft. Myers, Florida.

Cole, T. M., and Buchak, E. M. (1995). "CE-QUAL-W2: A TwoDimensional, Laterally Averaged, Hydrodynamic and Water Quality Model, Version 2.0 User Manual," Draft Instruction Report, US Army Engineer Waterways Experiment Station, Vicksburg, MS

Committee on Tidal Hydraulics. (1963). Salt water intrusion Lake Washington ship canal, Seattle, WA, U.S. Army Corps of Engineers

Ding Xingrui, and Zhou HuaXing. (1988). Design and test of the saltprevention system at Haihe lock, Technical report No. 3, Tianjin Research Institute of Water Transport Engineering, Tianjin, China.

Dock and Harbor Authority. (1999). Shiplift and transfer systems, Vol. 79, January/February, No. 893, p. 213. 
Environmental and Hydraulics Laboratory. (1986). "CE-QUAL-W2: A Two-Dimensional, Laterally Averaged, Hydrodynamic and Water Quality Model, User Manual," Instruction Report E-86-5, US Army Engineer Waterways Experiment Station, Vicksburg, MS

Hillen, J. G., Ockhuysen, C. P., and Kuur, P. (1984). The Technical and Economic aspects of the Water Separation System of the Krammer Locks, Water Science Technology, Rotterdam, Vol. 16, 131-140.

Kerstma, J., Kolkman, P. A., Regeling, H. J., and Venis W. A. (1994). Water Quality Control at Ship Locks - Prevention of Salt- and Fresh Water Exchange, A. A. Balkeme, Rotterdam.

Keulegan, G. H. (1957). An experimental study of the motion of saline water from locks into fresh water channels, Thirteenth progress report on model laws for density currents, National Bureau of Standards, Report No. 5168.

Keulegan, G. H. (1966). The mechanism of an arrested saline wedge, Chapter 11 in Estuary and Coastline Hydrodynamics, A. T. Ippen, ed. McGraw Hill Inc.

Kiamco, C. (1999). Note on Saltwater intrusion, Panama Canal Commission, unpublished manuscript.

Kolkman, P. A. (1986). Methods employed to limit saltwater-freshwater exchange in locks. Delft Hydraulics Comm. No. 364. Delft, the Netherlands.

Kolkman, P. A., and Slagter, J. C. (1976). The Kreekrak Locks on the Scheldt-Rhine Connection. Riijkswaterstaat Communications No. 24 (Also Delft Hydr. Lab. Publ. No. 160).

Long G. L., Eiland, R. G., and Mullnix, L. A. (1957). Occurrence and control of salt intrusion through navigation locks, U.S. Army Engineer Committee on Tidal Hydraulics, Paper presented at the ASCE Jackson Convention, February 1957.

Mausshardt, Sherrill, and Singleton, Glen. (1995). Mitigation Salt-Water Intrusion through Hiram M. Chittenden Locks, Journal of Waterway, Port, Coastal, and Ocean Engineering, American Society of Civil Engineers, July/August 1995.

McAnally, W. H. (1973). "Mixing of salinty-stratified water by pneumatic barriers," Research Report 73-4, Waterways Experiment Station, Vicksburg, MS.

Monadier P. (1981). Probleme de la remontee des eaux salees par les ecluses maritimes, example de l'ecluse de Mardyck a dunkerque. La Houille Blanche, vol. 36/2-3, 121-127. 
Ockhuysen C. P. (1983). A mathematical advection-dispersion model to optimize the freshwater and salt-water intrusion due to the exchange in navigation locks, Proc. XX IAHR Congress, Moscow, Vol. 5, 431-439.

Permanent International Association of Navigation Congress (PIANC), Supplement Bulletin No. 55. (1982). Final Report of the International Commission for the Study of Locks, Salt water penetration control devices, Chapter 12, p. 366-375

Permanent International Association of Navigation Congresses (PIANC). (1993). Problems Created by Saltwater Infiltration, Report of Working Group No. 6, Supplement to Bulletin No. 80, Brussels.

Ribes, G., and Blanchet, C. (1965). Les courants de densite et le projet de l'ecluse de Mardyck a dunkerque. La Houille Blanche, 20:48.

Tran D. N., and Merveille, J. L. (1986). Problemes de penetration des eaux sales dans les voies d'eau interieures, PIANC Bulletin No. 53, 79 - 95.

Van der Kuur, P. (1985). Locks with Devices to Reduce Salt Intrusion. J. Waterway, Port, Coastal, Ocean Eng., Proceedings of the American Society of Civil Engineers, vol. 111, No. 6, 1009-1021.

Whitehead, R. H. (1915). Hydraulics of the locks of the Panama Canal, Engineering Congress, held in San Francisco, CA, USA.

Zhou HuaXing, Wang Bingzhe, Zhang Furan, and Sun Yuping. (1989). A study on the lock with the exchange system to reduce salt-water intrusion, Technical report No. 13, Tianjin Research Institute of Water Transport Engineering, Tianjin, China. 1 


\section{Appendix A Salt Loading Example Calculations}

\section{Introduction}

The objective of this portion of the work is to compute the amount of salt transferred from the ocean to the two fresh water lakes. The computations are based on the simple mixing model of Chapter 3 of this report.

The local datum used at Panama Canal is the Precise Level Datum (PLD). Mean sea level (msl) is 1.0 foot $(0.30 \mathrm{~m})$ above the PLD on the Pacific side and 0.204 feet $(0.06 \mathrm{~m})$ on the Atlantic side. For purposes of this study, the difference between PLD and msl is ignored and all levels are referred with respect to the msl. This assumption does not make any significant change in the results.

The two locks on the Pacific Ocean side are the Miraflores Locks. The lock between the Miraflores Lake and the Gatun Lake is called Pedro Miguel lock. The three locks on the Atlantic Ocen side are called the Gatun Locks. For convenience of reference, the six locks in the system are given the following notation.

L1: Lowest Miraflores lock on the Pacific side

L2: Lock between Miraflores Lake and L1.

L3: Lock between Miraflores Lake and Gatun Lake. (Pedro Miguel)

L4: Highest Gatun lock directly connected to Gatun Lake.

L5: Middle Gatun lock on Atlantic Side

L6: Lowest Gatun lock connected to Atlantic Ocean.

A schematic longitudinal section of all the locks is given in Figure A1. This figure provides dimensions, lifts and relevant levels of all the locks.

Physical characteristics of the six locks at the Panama Canal are given in Table A1. Salinity values obtained from limited field data are given in Table A2. Assumptions made for computations are listed in Table A3. Notation used in salinity computations is given in Table A4.

Calculations presented in Appendix A were performed in non-SI units. To convert values to SI units, use the conversion factors given on page ix of this report. 


\begin{tabular}{|c|c|c|c|c|c|c|c|}
\hline \multicolumn{8}{|c|}{$\begin{array}{l}\text { Table A1 } \\
\text { Physical Characteristics of Panama Canal Locks }\end{array}$} \\
\hline Lock \# & $\begin{array}{l}\text { Lock Width \& } \\
\text { Length (ft) }\end{array}$ & $\begin{array}{l}\text { Lift } \\
\text { (ft) }\end{array}$ & $\begin{array}{l}\text { Lift Volume } \\
\text { (cft) }\end{array}$ & $\begin{array}{l}\text { Bed Level } \\
\text { (ft) }\end{array}$ & $\begin{array}{l}\text { Sill Level } \\
\text { (ft) }\end{array}$ & $\begin{array}{l}\text { Height of Sill } \\
\text { above Bed } \\
\text { (ft) }\end{array}$ & $\begin{array}{l}\text { Volume of water } \\
\text { below Sill (cft) }\end{array}$ \\
\hline L 1 & $110 \times 1051$ & 26 & $3.005 \times 10^{6}$ & -52.0 & -18.3 & 33.7 & $3.896 \times 10^{6}$ \\
\hline $\mathrm{L} 2$ & $110 \times 1071$ & 28 & $3.298 \times 10^{6}$ & -20.33 & +11.3 & 31.63 & $3.487 \times 10^{6}$ \\
\hline L3 3 & $110 \times 1071$ & 31 & $3.652 \times 10^{6}$ & +11.0 & +37.3 & 26.3 & $3.334 \times 10^{6}$ \\
\hline L 4 & $110 \times 1071$ & 28 & $3.298 \times 10^{6}$ & +13.0 & +37.3 & 24.3 & $1.566 \times 10^{6}$ \\
\hline L 5 & $110 \times 1051$ & 29 & $3.352 \times 10^{6}$ & -15.33 & +15.0 & 30.0 & $3.468 \times 10^{6}$ \\
\hline L 6 & $110 \times 1051$ & 28 & $3.237 \times 10^{6}$ & -44.3 & -13.6 & 30.7 & $3.549 \times 10^{6}$ \\
\hline
\end{tabular}

Note: All levels are given with reference to the mean sea level(msl).

The difference between the mean sea level and the Panama Canal Precise Datum Level is ignored.

\begin{tabular}{|c|c|}
\hline \multicolumn{2}{|c|}{$\begin{array}{l}\text { Table A2 } \\
\text { Salinity values derived from field observations }\end{array}$} \\
\hline Location & Salinity (ppt) \\
\hline On the sea side of lowest lock on Pacific side (lock L1) & 10.0 \\
\hline Inside lock L1 & 8.0 \\
\hline Inside lock L2 & 1.5 \\
\hline Miraflores Lake & 1.0 \\
\hline Gatun Lake & 0.0 \\
\hline
\end{tabular}

Limitations of field data on salinity:

a. The time of measurement is not given. Hence range and stage of tide are not known.

$b$. The status of water level in the lock is not given; whether the level was after full lift or after the ship entered at a lower water elevation.

c. The size of ship is not reported.

d. Salinity readings are given to the first decimal value. 


\begin{tabular}{|c|c|}
\hline \multicolumn{2}{|c|}{$\begin{array}{l}\text { Table A3 } \\
\text { Assumptions made in salt loading computations }\end{array}$} \\
\hline S. No. & Assumption \\
\hline 1 & $\begin{array}{l}\text { Tidal variation in sea is not accounted for. All computations are made for } \\
\text { mean sea level (msl). }\end{array}$ \\
\hline 2 & $\begin{array}{l}\text { The mean sea level is assumed to be the same as Precise Level Datum } \\
\text { (PLD). }\end{array}$ \\
\hline 3 & $\begin{array}{l}\text { Number of lockages is assumed to be the same as the number of ship } \\
\text { transits. }\end{array}$ \\
\hline 4 & $\begin{array}{l}\text { Blockage ration of } 0.8 \text { is assumed for calculating submerged volume of ship } \\
\text { from the length, beam and draft dimensions. The average submerged volume } \\
\text { of a ship is assumed to be } 1,140,000 \mathrm{cft} \text {. }\end{array}$ \\
\hline 5 & Fifty percent mixing is assumed when lock gates are opened. \\
\hline 6 & $\begin{array}{l}\text { Ocean salinity is assumed to be } 35 \text { parts per thousand. The local salinity near } \\
\text { the lowest gate is expected to be much less because fresh water from the } \\
\text { lake is added to the sea for each ship transit and a transition zone exists } \\
\text { between the lowest locks and the open sea. Hence it is assumed that salinity } \\
\text { just outside the lowest lock is } 10 \text { ppt and salinity inside the lowest lock is } 8 \\
\text { ppt. }\end{array}$ \\
\hline 7 & Volume of water in Miraflores Lake is 670 million cft. \\
\hline 8 & $\begin{array}{l}\text { Net transfer of fresh water from the lakes to the sea is equal to } 52 \text { million } \\
\text { gallons per transit. }\end{array}$ \\
\hline
\end{tabular}

\section{Table A4}

\section{Notations used in salinity computations}

\begin{tabular}{|c|c|c|}
\hline Notation & Parameter & Magnitude \\
\hline \multicolumn{3}{|l|}{ Volumes } \\
\hline $\mathrm{V}_{1}$ & Volume of $\mathrm{L} 1$ below $\mathrm{msl}$ & $6,011,720 \mathrm{cft}$ \\
\hline V2 & Volume of L1 above sill after full lift & $5,121,523 \mathrm{cft}$ \\
\hline V3 & Average volume of submerged ship & $1,140,000 \mathrm{cft}$ \\
\hline V4 & Volume of water in L1 below msl with ship inside & $4,871,720 \mathrm{cft}$. \\
\hline V5 & Lift Volume of L1 & $3,005,860 \mathrm{cft}$ \\
\hline V6 & $\begin{array}{l}\text { The volume of water from L1 that will mix with water in L2. (i.e. volume of water above } \\
\text { sill on the L2 side minus the submerged ship volume with water in L2 (i. e. the volume } \\
\text { above sill on the L2 side minus the submerged ship volume }\end{array}$ & $3,981,523 \mathrm{cft}$ \\
\hline V7 & Volume of water in L2 above bed at $+26 \mathrm{ft}$ & $5,458,137 \mathrm{cft}$ \\
\hline V8 & Volume of water in L2 at +26 feet after ship enters $L 2$ & $4,318,137 \mathrm{cft}$ \\
\hline V9 & Lift volume in L2 & $3,298,680 \mathrm{cft}$ \\
\hline V10 & Volume of water in L2 at $+54 \mathrm{ft}$ without ship inside & $8,756,817 \mathrm{cft}$ \\
\hline V11 & Volume of water in L2 at $+54 \mathrm{ft}$ with ship inside & $7,616,817 \mathrm{cft}$. \\
\hline V12 & Volume of water in L3 at $+54 \mathrm{ft}$ without ship inside & $5,056,830 \mathrm{cft}$ \\
\hline V13 & Volume of water in L3 at $+54 \mathrm{ft}$ with ship inside & $3,916,830 \mathrm{cft}$ \\
\hline \multicolumn{3}{|l|}{ Salinity } \\
\hline S1 & Assumed salinity outside L1 & 10.0 ppt. \\
\hline S2 & Measured salinity inside L1 & $8.0 \mathrm{ppt}$ \\
\hline S3 & Measured salinity inside L2 & $1.5 \mathrm{ppt}$ \\
\hline S4 & Computed salinity in L1 after operation L1/1 & $5.52 \mathrm{ppt}$ \\
\hline S5 & Measured salinity in Miraflores Lake & $1 \mathrm{ppt}$ \\
\hline S6 & Computed salinity in L2 after operation L2/1 & $3.2 \mathrm{ppt}$ \\
\hline S7 & Computed salinity in L2 after operation L2/2 & $1.28 \mathrm{ppt}$ \\
\hline S8 & Salinity in L2 after ship leaves L2 and enters Miraflores Lake & $1.003 \mathrm{ppt}$ \\
\hline S9 & Salinity in L3 after ship enters L3 & 0.25 \\
\hline S10 & Salinity in $\mathrm{L} 3$ after raising ship to $+85 \mathrm{ft}$ & \\
\hline
\end{tabular}




\section{Computations for ship transiting from Pacific Ocean}

\section{Computations for Lock - L1}

$\underline{\text { Data }}$

Size of L1

Lift

Bed Elevation below msl

Volume of L1 below msl (V1)

Lock-2 side sill level of L1

Water depth above sill at full lift

Volume of L1 above sill (V2)

Average volume of submerged ship (V3)

Assumed salinity outside L1 (S1)

Assumed salinity inside L1 (S2)

Assumed salinity of water in L2 (S3)
1051 feet $x 110$ feet

26 feet

- 52 feet

$=110 \times 1051 \times 52$

$=6,011,720$ cubic feet.

- 18.3 feet

$=(26+18.3)=44.3$ feet

$=110 \times 1051 \times 44.3$

$=5,121,523$ cubic feet

$=1,140,000$ cubic feet

$=10.0 \mathrm{ppt}$.

$=8.0 \mathrm{ppt}$

$=1.5 \mathrm{ppt}$

Initial Status:

Lock gates to the sea are open.

Ship is waiting out in the sea to get in.

Sea level $=$ msl.

Water Elevation in $\mathrm{L} 1=\mathrm{msl}$

\section{Operation L1/1}

Bring the ship in L1 from sea and close gates.

$\underline{\text { Result }}$

The volume $\left(\mathrm{V}_{1}\right)$ will be reduced by the submerged volume of $\operatorname{ship}\left(\mathrm{V}_{3}\right)$

Volume of water in $\mathrm{L} 1$ below msl with ship inside $\left(\mathrm{V}_{4}\right)=\left(\mathrm{V}_{1}\right)-\left(\mathrm{V}_{3}\right)$

$$
\begin{aligned}
& =6,011,720-1,140,000 \\
& =4,871,720 \text { cubic feet. }
\end{aligned}
$$

\section{Operation L1/2}

Raise water level in L1 by 26 feet by releasing water from L 2 to L1

$\underline{\text { Result }}$

$$
\begin{aligned}
\text { Volume of water added (V5) } & =\mathrm{Lift} \text { volume of } \mathrm{L} 1 \\
& =110 \times 1051 \times 26 \\
& =3,005,860 \text { cubic feet }
\end{aligned}
$$


Entire volume of water in L1 participates in mixing with water from L2 because the inflow is from the bottom of lock.

Total volume in $\mathrm{L} 1 \quad=\left(\mathrm{V}_{4}\right)+(\mathrm{V} 5)$

$$
\begin{array}{r}
=4,871,720 \\
+3,005,860 \\
\hline 7,877,580
\end{array}
$$

Salinity of mixture in L1(S4)

$\left[\left(\mathrm{V}_{4}\right)+\left(\mathrm{V}_{5}\right)\right]$

$$
\begin{array}{ll}
\begin{array}{l}
\text { Salinity of mixture in L1(S4) } \\
{\left[\left(\mathrm{V}_{4}\right)+\left(\mathrm{V}_{5}\right)\right]}
\end{array} & =\left[\left(\mathrm{V}_{4}\right) \times(\mathrm{S} 2)\right]+[(\mathrm{V} 5) \times(\mathrm{S} 3)] / \\
& =\frac{(4,871,720)(8)+(3,005,860)(1.5)}{(7,877,580)} \\
& =\frac{38,973,760+4,508,790}{(7,877,580)} \\
& =5.52 \mathrm{ppt} \\
\text { Exchange coefficient } & =(5.52 / 10.0)=0.552
\end{array}
$$

\section{Computations for Lock - L2}

$\underline{\text { Data }}$

Size of L2

Lift

Bed Elevation below MSL

Water depth at $+26 \mathrm{ft}$

Volume of water in L2

at +26 feet $\left(\mathrm{V}_{7}\right)$

Lift Volume of L2 (V9)

Salinity (S3)
1071 feet $x 110$ feet

28 feet

- 20.33 feet

46.33 feet

$=110 \times 1071 \times 46.33$

$=5,458,137$ cubic feet

$=110 \times 1071 \times 28$

$=3,298,680$ cubic feet

$=1.5 \mathrm{ppt}$ (assumed)

Initial Status:

After releasing water from L2 to L1, water level in L2 drops from +54 to +26 feet Water elevation in $\mathrm{L} 1=+26$ '

Salinity in $\mathrm{L} 1=5.52 \mathrm{ppt}$

Salinity in L2 $=1.5 \mathrm{ppt}$

Ship is in L1

\section{Operation L2/1}

Open gates between L2 and L1

Move ship from L1 to L2

Assume 100\% mixing

\section{Comments}

The volume of water from L1 that will mix with water in L2 is the volume above sill on the L 2 side minus the submerged ship volume 


$$
\begin{aligned}
\left(\mathrm{V}_{6}\right) \quad & \left(\mathrm{V}_{2}\right)-\left(\mathrm{V}_{3}\right) \\
= & 5,121,523 \\
- & 1,140,000 \\
- & 3,981,523 \text { cubic feet }
\end{aligned}
$$

This volume will mix with the entire volume of water in L2 above bed $\left(\mathrm{V}_{7}\right)$.

$\underline{\text { Result }}$

Salinity of mixture in L2: (S6) =

$\left[\left(\mathrm{V}_{6}\right) \times\left(\mathrm{S}_{4}\right)\right]+\left[\left(\mathrm{V}_{7}\right) \times(\mathrm{S} 3)\right] /\left[\left(\mathrm{V}_{6}\right)+\left(\mathrm{V}_{7}\right)\right]$

$=\frac{(3,981,523 \times 5.52)+(5,458,137 \times 1.5)}{3,981,523+5,458,137}$

$3,981,523+5,458,137$

$$
\begin{aligned}
& =\frac{21,978,007+8,187,205}{9,439,660} \\
& =\frac{30,165,212}{9,439,660} \\
& =3.2 \mathrm{ppt}
\end{aligned}
$$

The measured salinity $(\mathrm{S} 3)=1.5 \mathrm{ppt}$

Hence mixing $=47 \%$, i.e. coefficient of mixing $=0.47$

Status at the end of operation L2/1

Ship is in L2

Volume of water in L2 at $+26 \mathrm{ft}$ without ship (V7) $\quad=5,458,137$

Subtract ship volume (V3) $\quad \underline{1,140,000}$

Volume of water in $\mathrm{L} 2$ at +26 feet

$4,318,137$

with ship inside $\left(\mathrm{V}_{8}\right)$

$=1.5 \mathrm{ppt}$

\section{Operation L2/2}

Close gates between L2 and L1

Raise water level in L2 by 28 feet by releasing water from

Miraflores Lake

$\underline{\text { Result }}$

Salinity of mixture: (S7)

$=\left[\left(\mathrm{V}_{8}\right) \times\left(\mathrm{S}_{3}\right)\right]+\left[\left(\mathrm{V}_{9}\right) \times\left(\mathrm{S}_{5}\right)\right] /\left[\left(\mathrm{V}_{8}\right)+\left(\mathrm{V}_{9}\right)\right]$

$=\underline{(4,318,137 \times 1.5)+(3,298,680 \times 1.0)}$

$(7,616,817)$ 


$$
\begin{aligned}
& =\frac{6,477,205+3,298,680}{7,616,817} \\
& =1.28 \mathrm{ppt}
\end{aligned}
$$

Status after completion of operation L2/2

Water elevation in L2 and Miraflores Lake $\quad=+54$ feet

Volume of water in L2 at $+54 \mathrm{ft}$ without ship $\left(\mathrm{V}_{10}\right)$

$=110 \times 1071 \times 74.33$

$=8,756,817$

Subtract ship volume (V3) $\quad=\underline{1,140,000}$

Volume of water in L2 with ship $\left(\mathrm{V}_{11}\right) \quad 7,616,817 \mathrm{cft}$.

\section{Operation L2/3}

Open gates between L2 and Miraflores Lake

Move ship from L2 into Miraflores Lake

$\underline{\text { Result }}$ $10^{6} \mathrm{cft}$.

Volume of water in Miraflores Lake between $+53 \mathrm{ft}$ and $+55 \mathrm{ft}=87 \mathrm{x}$

Assume total volume $=870 \times 10^{6}$ cubic feet.

Assume that $100 \%$ mixing with lock water takes place with this volume of lake. lake water.)

(Instead of assuming that only the volume of water above sill mixes with

Salinity of mixture in L2: (S8)

$$
\begin{aligned}
& =\frac{\left(870 \times 10^{6} \times 1.0\right)+(7,616,817 \times 1.28)}{\left(877.6 \times 10^{6}\right)} \\
& =\frac{879.76 \times 10^{6}}{877.6 \times 10^{6}} \\
& =1.003 \mathrm{ppt}
\end{aligned}
$$

Also, note that $26 \times 10^{6}$ gallons of fresh water is added per ship transit, from Pacific side, which is equal to $3.47 \times 10^{6} \mathrm{cft}$. This quantity with approximately zero salinity is about $50 \%$ of the magnitude of the lock water volume with a salinity of 1.28 ppt. This helps in reducing the salinity of Miraflores Lake water.

\section{Computations for Lock - L3}

$\underline{\text { Status }}$

Ship is in Miraflores Lake

Water elevation in L3 and Miraflores $=+54 \mathrm{ft}$

Salinity in Miraflores $=1.0 \mathrm{ppt}$

Salinity in $\mathrm{L} 3 \approx 0$ 


\section{Operation L3/1}

Open gates between L3 and Miraflores.

Move ship from Miraflores to L3.

$\underline{\text { Result }}$

water elevation: $+54 \mathrm{ft} \mathrm{msl}$

lock bottom +11

water depth $\quad=(54-11)=43 \mathrm{ft}$

Volume of water in L3 at $+54 \mathrm{ft}$ without ship: (V12)

$=110 \times 1071 \times 43$

$=5,056,830 \mathrm{cft}$

subtract ship volume (V3) $\quad=\underline{1,140,000}$

Volume of water in L3 at $+54 \mathrm{ft}$ with ship inside (V13) $\quad 3,916,830 \mathrm{cft}$

If we assume that half of this volume mixes fully with Miraflores Lake water with salinity of $1.0 \mathrm{ppt}$, then salinity in L3 will be s9 $=0.25 \mathrm{ppt}$.

\section{Operation L3/2}

Close gate between L3 and Miraflores Lake

Raise water level in L3 by $31 \mathrm{ft}$

$\underline{\text { Result }}$

Fresh water from Gatun Lake added to L3 for raising water level by $31 \mathrm{ft}$.

$$
\begin{aligned}
& =110 \times 1071 \times 31 \\
& =3,652,110 \mathrm{cft}
\end{aligned}
$$

Salinity of mixture in $\mathrm{L} 3$ after raising ship to $+85 \mathrm{ft}$ (S10)

$$
\begin{gathered}
=\frac{[(3,652,100) \times(0)]+3,916,8300.25]}{7,577,940} \\
=0.13 \mathrm{ppt}
\end{gathered}
$$

Summary: Estimates of salinities in three locks (L1, L2 and L3) resulting from ship transiting from Pacific Ocean are given in Table A5. Estimated transfer coefficients are given in Table A6. 


\begin{tabular}{|c|c|c|}
\hline \multicolumn{3}{|c|}{$\begin{array}{l}\text { Table A5 } \\
\text { Estimates of salinities resulting from ships transiting from } \\
\text { Pacific Entrance }\end{array}$} \\
\hline Ship Transit & Location and stage of transit & $\begin{array}{l}\text { Computed } \\
\text { Salinity (ppt) }\end{array}$ \\
\hline $\begin{array}{l}\text { From Pacific Ocean } \\
\text { To Lock } 1\end{array}$ & $\begin{array}{l}\text { Inside L1 } \\
\text { After full lift }\end{array}$ & 5.52 \\
\hline $\begin{array}{l}\text { From Lock } 1 \\
\text { To Lock } 2\end{array}$ & $\begin{array}{l}\text { Inside } L 2 \\
\text { After moving ship from } L 1 \text { to } L 2\end{array}$ & 1.50 \\
\hline & $\begin{array}{l}\text { Inside L2 } \\
\text { After full lift }\end{array}$ & 1.28 \\
\hline $\begin{array}{l}\text { From Lock } 2 \\
\text { To Miraflores Lake }\end{array}$ & $\begin{array}{l}\text { Inside L2 } \\
\text { After moving ship from L2 to Miraflores Lake }\end{array}$ & 1.003 \\
\hline $\begin{array}{l}\text { From Miraflores Lake } \\
\text { To Lock } 3\end{array}$ & $\begin{array}{l}\text { Inside L3 } \\
\text { After moving ship from Miraflores Lake to L3 }\end{array}$ & 0.25 \\
\hline & $\begin{array}{l}\text { Inside L3 } \\
\text { After full lift }\end{array}$ & 0.13 \\
\hline
\end{tabular}

\begin{tabular}{|c|c|c|}
\hline \multicolumn{3}{|c|}{$\begin{array}{l}\text { Table A6 } \\
\text { Estimate of transfer coefficients for salt loading from Pacific } \\
\text { Entrance }\end{array}$} \\
\hline Location and stage & Salinity (ppt) & Transfer Coefficient (\%) \\
\hline Pacific Ocean & 35.0 & 100 \\
\hline $\begin{array}{l}\text { Pacific Ocean } \\
\text { just outside L1 }\end{array}$ & 10.0 & 28.571 \\
\hline $\begin{array}{l}\text { Inside Lock L1 } \\
\text { After ship enters }\end{array}$ & 8.0 & 22.857 \\
\hline $\begin{array}{l}\text { Inside Lock L1 } \\
\text { After full lift }\end{array}$ & 5.52 & 15.771 \\
\hline $\begin{array}{l}\text { Inside Lock L2 } \\
\text { After ship enters }\end{array}$ & 1.5 & 4.286 \\
\hline $\begin{array}{l}\text { Inside Lock L2 } \\
\text { After full lift }\end{array}$ & 1.28 & 3.657 \\
\hline $\begin{array}{l}\text { Inside Lock L2 } \\
\text { After ship leaves }\end{array}$ & 1.003 & 2.866 \\
\hline Miraflores Lake & 1.00 & 2.857 \\
\hline $\begin{array}{l}\text { Inside Lock L3 } \\
\text { After ship enters }\end{array}$ & 0.25 & 0.71 \\
\hline $\begin{array}{l}\text { Inside Lock L3 } \\
\text { After full lift }\end{array}$ & 0.13 & 0.37 \\
\hline
\end{tabular}

\section{Miraflores Lake Salt Loading Estimate}

\section{Salt loading per transit (set 1)}

Inflow

: Volume of water in L2 at $+54 \mathrm{ft}$ with ship inside (V11)

$$
=7,616,817 \text { (with ship inside) }
$$




$$
\text { Salinity inside L2 after full lift (S7) } \quad=1.28 \text { ppt. }
$$

Assume that $50 \%$ of this mixes with lake water.

$$
\begin{aligned}
\text { Weight of salt } \quad & =(7,616,817)(62.6 \mathrm{lb} / \mathrm{cft}) \times \frac{(1.28 / 2)}{1000 \mathrm{lb}} \mathrm{lb} \\
& =304,185 \mathrm{lbs} .
\end{aligned}
$$

Outflow

When the water level in L2 is lowered by $28 \mathrm{ft}$, salt moves out.

Decrease in volume of lake water

$$
\begin{aligned}
& =110 \times 1071 \times 28 \\
& =3,298,680 \mathrm{cft}
\end{aligned}
$$

$$
\text { Lake salinity } \quad=1.0 \mathrm{ppt}
$$

$$
\begin{aligned}
\text { Weight of salt out } \quad & =(3,298,680)(62.4) \times \underline{1.0} \\
& =205,838 \mathrm{lb} .
\end{aligned}
$$

Net salt added per transit $\quad=304,185 \mathrm{lb}$

$$
\text { - 205,838 lb }
$$

98, $347 \mathrm{lb}$ per transit

\section{Salt loading per transit (set 2)}

Assume the same inflow as in set1.

Outflow

Assume that the local salinity of Miraflores Lake just outside L2 was $1.15 \mathrm{ppt}$ (instead of 1.0 assumed in set1)

$$
\begin{aligned}
& \text { Salt out }=(3,298,680)(62.4)(1.15 / 1000) \\
& =236,713 \mathrm{lb} / \text { transit }
\end{aligned}
$$




\section{Salt loading per transit (set 3)}

It is seen that a small change in the magnitude of salinity of water in Miraflores form 1.0 to 1.15 changes the magnitude of net salt addition per transit from $98,347 \mathrm{lb}$ per transit to $67,472 \mathrm{lb}$ per transit. With an estimated 14,000 transits per year, this makes a difference of 432 million pounds per year.

Instead of assuming 50 percent of lock water salt mixing with lake water, we assume 40 percent, the salt input changes from 304,185 to 243,348 lbs per transit. The following results of sensitivity analysis computations illustrate the importance of the accuracy of salinity magnitudes.

\begin{tabular}{||l|l|l|l||}
\hline \multicolumn{4}{|l||}{$\begin{array}{l}\text { Table A7 } \\
\text { Sensitivity analysis illustrating impact of Miraflores Lake salinity magnitude }\end{array}$} \\
\hline \hline Miraflores Lake Salinity Outside L2 & $\begin{array}{l}\text { Salt Inflow (Ib) } \\
\text { Per transit }\end{array}$ & $\begin{array}{l}\text { Salt Outflow (lb) } \\
\text { Per transit }\end{array}$ & $\begin{array}{l}\text { Net Salt Input (Ib) } \\
\text { Per transit }\end{array}$ \\
\hline \hline 1.00 & 243,348 & 205,838 & 37,510 \\
\hline 1.10 & 243,348 & 226,421 & 16,927 \\
\hline 1.15 & 243,348 & 236,713 & 6,635 \\
\hline 1.16 & 243,348 & 238,772 & 4,576 \\
\hline 1.17 & 243,348 & 240,830 & 2,518 \\
\hline 1.18 & 243,348 & 242,888 & 459 \\
\hline 1.182 & 243,348 & 243,300 & 48 \\
\hline
\end{tabular}

\section{Computations for ship transiting from Atlantic Ocean}

Notation is given in Table A8.

\section{Computations for Lock L6}

$\underline{\text { Status }}$

Lock gates to the sea are open.

Ship is waiting outside to get in.

Sea level $=\mathrm{msl} \approx$ P.L.D.

$\underline{\text { Data }}$

Bottom level of L6 $=-44.3$ '

Volume of water in L6 at msl (V14)

$$
\begin{aligned}
& =110 \times 1051 \times 44.3 \\
& =5,121,523 \text { cubic feet }
\end{aligned}
$$

Assume salinity inside L6 $(\mathrm{S} 11)=8 \mathrm{ppt}$ 


\section{Operation L6/1}

Bring the ship in and close gates.

$\underline{\text { Result }}$

Volume of water in lock will be reduced by the submerged volume of ship

V14

$5,121,523$

V3

$-\underline{1,140,000}$

Volume of water in L6 with ship (V15) $4,981,523 \mathrm{cft}$.

\section{Operation L6/2}

Raise water level by $28 \mathrm{ft}$ above msl by using water from L5.

$\underline{\text { Result }}$

Volume of water added (V16) $\quad=110 \times 1051 \times 28$

$$
=3,237,080 \mathrm{cft}
$$

Assume salinity of L5 (S12)

$=1.5 \mathrm{ppt}$

Salinity of mixture in L6 (S13)

$$
\begin{aligned}
& =\frac{(4,981,523 \times 8)+(3,237,080 \times 1.5)}{8,218,603} \\
& =\frac{39,852,184+4,855,620}{8,218,603} \\
& =5.44 \text { ppt. }
\end{aligned}
$$

\section{Computations for Lock - L5}

$\underline{\text { Status }}$

$$
\begin{aligned}
& \text { Water elevation in } \mathrm{L} 6=+28 \mathrm{ft} \\
& \text { Water elevation in } \mathrm{L} 5=+28 \mathrm{ft} \\
& \text { Salinity in L6 after full lift }=5.44 \mathrm{ppt} \\
& \text { Salinity in L5 }=1.5 \mathrm{ppt}
\end{aligned}
$$

\section{Operation L5/1}

Open gates between L6 and L5

Move ship from L6 to L5

$\underline{\text { Result }}$

Total water depth $=(28+15.33)=43.33 \mathrm{ft}$

Volume of water in L5 without ship at elevation +28

$\mathrm{V} 17=110 \times 1051 \times 43.33$

$$
=5,009,381 \mathrm{cft}
$$

For conservative estimate, assume $100 \%$ mixing, with entire volume of water in L6 
Salinity of mixture

In L5 (S14)

$$
\begin{aligned}
& =\frac{(4,981,523 \times 5.44)+(5,009,381 \times 1.5)}{9,990,904} \\
& =\frac{27,099,485+7,514,071}{9,990,904} \\
& =3.46 \mathrm{ppt}
\end{aligned}
$$

Salinity assumed in L5 was 1.5

Mixing $=43.35 \%$ say $40 \%$

Status after moving ship from L6 to L5

$\begin{array}{cc}\text { Volume of water in L5 (V17) } & =5,009,381 \\ \text { - submerged ship volume (V3) } & -1,140,000 \\ \text { Volume of water in L5 with ship (V18) } & =3,869,381\end{array}$

\section{Operation L5/2}

from L4

Raise water level by $29 \mathrm{ft}$ from elevation $+28 \mathrm{ft}$ to $57 \mathrm{ft}$ by adding water

$\underline{\text { Result }}$

Volume of water added (V19) $\quad=110 \times 1051 \times 29$

$=3,352,690 \mathrm{cft}$

In the absence of field data, salinity of L4 is assumed to be zero.

Salinity of mixture in L5 $(\mathrm{S} 15)=(3,869,381 \times 1.5)+(3,352,690 \times 0)$

$7,222,071$

$$
=0.8 \mathrm{ppt}
$$

\section{Computations for Lock - L4}

$\underline{\text { Status }}$

Water elevation in $\mathrm{L} 5=$ water elevation in $\mathrm{L} 4=+57 \mathrm{ft}$

Ship is in L5

\section{Operation L4/1}

Open gates between L5 and L4 and move the ship to L4

Bed elevation $=+13$

Water depth $=44 \mathrm{ft}$

$\underline{\text { Result }}$

Volume of water in $\mathrm{L} 4$ above sill at water at elevation $+57 \mathrm{ft}$

$\begin{aligned} \text { Volume }(\mathrm{V} 20) & =110 \times 1071 \times 44 \\ & =5,183,640 \mathrm{cft}\end{aligned}$ 
Salinity of water in L5 $=0.8$ ppt.

Assume 100\% mixing after gates open.

Volume of water in L5 with ship inside (V21) $=3,869,381 \mathrm{cft}$.

Salinity of water in L4 $=0.15 \mathrm{ppt}$ (assumed)

Salinity of mixture in L4: $(\mathrm{S} 16)=$

$$
\begin{aligned}
& \frac{(3,869,381 \times 0.8)+(5,183,640 \times 0.15)}{(3,869,381+5,183,640)} \\
& =\frac{3,095,505+777,546}{9,053,021} \\
& =0.43 \mathrm{ppt}
\end{aligned}
$$

It is assumed that salinity of water in L4 is $0.15 \mathrm{ppt}$.

This gives $[0.15 / 0.43]=35 \%$ mixing

\section{Operation L4/2}

Raise water level in L4 from elevation +57 to $+85^{\prime}$ (by 28 feet), using water from Gatun Lake.

$\underline{\text { Result }}$

Volume of water in L4 without ship (V21)

$=5,183,640$

Subtract ship volume

- $\underline{1,140,000}$

Volume of water in L4 with ship inside (V22)

$4,043,640$

Salinity in L4 $=0.15$ ppt.

Volume of fresh water added

$=110 \times 1071 \times 28$

$=3,298,680 \mathrm{cft}$.

Salinity of mixture in L4: $(\mathrm{S} 18)=\underline{4,043,640 \times 015}$

$7,342,320$

$$
=0.083 \mathrm{ppt}
$$

\section{Computations for Gatun Lake}

Water level

Sill level

Difference

Volume of salt water above sill $=110 \times 1071 \times 47.7 \mathrm{cft}$

$$
=5,619,537
$$

Subtract ship volume

$$
\equiv 1,140,000
$$$$
4.479,537 \mathrm{cft}
$$

Weight of water $=279.5 \times 10^{6} \mathrm{lb}$

Salinity $=0.083 \mathrm{ppt}$ 


$$
\text { Weight of salt }=279.5 \times 10^{6} \times \frac{0.083}{1000}
$$

$$
=23,198 \mathrm{lbs} \text {. }
$$

Assuming 50\% mixing, weight of salt added per transit $=11,600 \mathrm{lbs}$.

Summary: Estimates of salinities in three locks (L4, L5 and L6) resulting from

\begin{tabular}{|c|c|c|}
\hline \multicolumn{3}{|c|}{$\begin{array}{l}\text { Table A8 } \\
\text { Notations used in salinity computations }\end{array}$} \\
\hline Notation & Parameter & Magnitude \\
\hline \multicolumn{3}{|l|}{ Volumes } \\
\hline V14 & Volume of L6 below msl & $5,121,523 \mathrm{cft}$ \\
\hline V15 & Volume of water in L6 above bed with ship inside & $4,981,523 \mathrm{cft}$ \\
\hline V16 & Lift Volume of L6 & $3,237,080 \mathrm{cft}$ \\
\hline V17 & Volume of water in L5 at $+28 \mathrm{ft}$ without ship inside & $5,009,381 \mathrm{ctt}$. \\
\hline V18 & Volume of water in $\mathrm{L} 5$ at $+28 \mathrm{ft}$ with ship inside & $3,869,381 \mathrm{cft}$ \\
\hline V19 & Volume of water added to L5 from L4 & $3,352,690 \mathrm{cft}$ \\
\hline V20 & Volume of water in L4 at elevation $+57 \mathrm{ft}$ & $5,183,640 \mathrm{cft}$ \\
\hline V21 & Volume of water in L4 at $+57 \mathrm{ft}$ without ship inside & $5,183,640 \mathrm{cft}$ \\
\hline V22 & Volume of water in L4 at $+57 \mathrm{ft}$ with ship inside & $4,043,640 \mathrm{cft}$ \\
\hline \multicolumn{3}{|l|}{ Salinity } \\
\hline $\mathrm{S} 11$ & Assumed salinity inside L6 & $8.0 \mathrm{ppt}$ \\
\hline S12 & Salinity inside L5 & $1.5 \mathrm{ppt}$ \\
\hline S13 & Computed salinity in L6 after full lift & $5.44 \mathrm{ppt}$ \\
\hline $\mathrm{S} 14$ & Computed salinity in L5 after operation L5/1 & $3.46 \mathrm{ppt}$ \\
\hline S15 & Salinity in L5 after full lift & $0.8 \mathrm{ppt}$ \\
\hline S16 & Computed salinity in L4 after operation L4/1 & $0.43 \mathrm{ppt}$ \\
\hline $\mathrm{S} 17$ & Computed salinity in L4 after operation L4/2 & $0.083 \mathrm{ppt}$ \\
\hline
\end{tabular}
ship transiting from Ocean are given in Table A9. Estimated transfer coefficients are given in Table A10. 


\begin{tabular}{|c|c|c|c|}
\hline \multicolumn{4}{|c|}{$\begin{array}{l}\text { Table A9 } \\
\text { Estimate of salinities resulting from ships transiting from Alantic } \\
\text { Entrance }\end{array}$} \\
\hline Source & $\begin{array}{l}\begin{array}{l}\text { Volume of water } \\
\text { (cubic feet) }\end{array} \\
\end{array}$ & Location and Time & $\begin{array}{l}\begin{array}{l}\text { Salinity } \\
\text { (ppt) }\end{array} \\
\end{array}$ \\
\hline Atlantic Ocean & & $\begin{array}{l}\text { Atlantic Ocean just outside L1 } \\
\text { All times. }\end{array}$ & 10.0 \\
\hline Lock L6 & & $\begin{array}{l}\text { Inside L6 } \\
\text { All times }\end{array}$ & 8.0 \\
\hline Lock L6 & & $\begin{array}{l}\text { Lock L6 } \\
\text { After full lift }\end{array}$ & 5.44 \\
\hline $\begin{array}{l}\text { From Lock L6 } \\
\text { To Lock L5 }\end{array}$ & $4,981,523$ & $\begin{array}{l}\text { Lock L5 } \\
\text { After exchange with L6 }\end{array}$ & 1.50 \\
\hline Lock L5 & & $\begin{array}{l}\text { Lock L5 } \\
\text { After full lift }\end{array}$ & 0.80 \\
\hline $\begin{array}{l}\text { From Lock L5 } \\
\text { To Lock } 4\end{array}$ & $3,869,381$ & $\begin{array}{l}\text { Lock L4 } \\
\text { After moving ship from } L 5 \text { to } L 4\end{array}$ & 0.43 \\
\hline \multirow[t]{2}{*}{ Lock L4 } & & $\begin{array}{l}\text { Lock L4 } \\
\text { After full lift }\end{array}$ & 0.083 \\
\hline & & $\begin{array}{l}\text { Gatun Lake } \\
\text { All times }\end{array}$ & 0.0 \\
\hline
\end{tabular}

\section{Table A10}

Estimate of salt transfer coefficients from Atlantic Entrance

\begin{tabular}{||l|l|l||}
\hline \hline Location and stage & Salinity (ppt) & Transfer Coefficient (\%) \\
\hline \hline Atlantic Ocean & 35.0 & 100 \\
\hline $\begin{array}{l}\text { Atlantic Ocean } \\
\text { just outside L6 }\end{array}$ & 10.0 & 28.6 \\
\hline $\begin{array}{l}\text { Inside Lock L6 } \\
\text { After ship enters }\end{array}$ & 8.0 & 22.8 \\
\hline $\begin{array}{l}\text { Inside Lock L6 } \\
\text { After full lift }\end{array}$ & 5.44 & 15.54 \\
\hline $\begin{array}{l}\text { Inside Lock L5 } \\
\text { After ship enters }\end{array}$ & 1.5 & 4.29 \\
\hline $\begin{array}{l}\text { Inside Lock L5 } \\
\text { After full lift }\end{array}$ & 0.8 & 2.29 \\
\hline $\begin{array}{l}\text { Inside Lock L4 } \\
\text { After ship enters }\end{array}$ & 0.15 & 0.43 \\
\hline $\begin{array}{l}\text { Inside Lock L4 } \\
\text { After full lift }\end{array}$ & 0.083 & 0.24 \\
\hline \hline
\end{tabular}




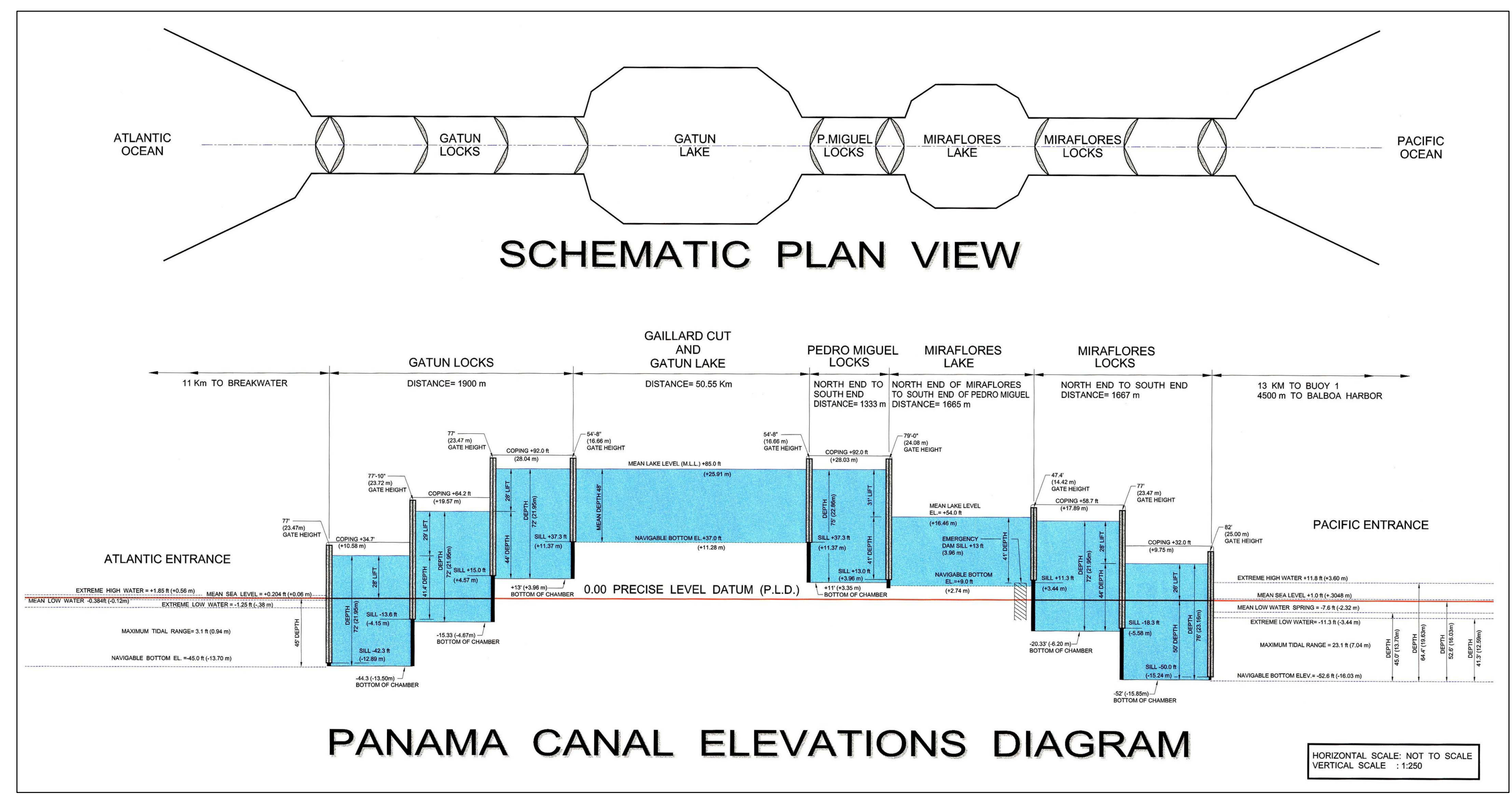

Figure A1. Schematic plan and elevations for Panama Canal Locks 


\section{Appendix B}

\section{Summary of Saltwater} Intrusion Problems at Inland Navigation Channels in the United States

\footnotetext{
A literature search for information on the environmental effects of saltwater intrusion in the United States (USA) yielded no bona fide before and after studies of saltwater intrusion due to inland navigation channels. Likewise, Brogdon (1986) surveyed coastal Districts of the U.S. Army Corps of Engineers to obtain pre- and post-channel deepening salinity data, but the survey yielded very little useful data. Intuitively, any inland navigation channel which involved significant increases in the natural depths of estuaries or which opened a new inlet to the ocean likely caused saltwater intrusion. Thus, many inland navigation channels have probably caused saltwater intrusion, but neither the magnitude nor the extent has been documented. Navigation channels discussed herein are limited to those which are definitively known to have caused saltwater intrusion, based on knowledgeable sources, and those which limited data indicate that saltwater intrusion is likely to have occurred.

The Committee on Tidal Hydraulics reviewed 44 U.S. Army Corps of Engineers (USACE) projects in Technical Bulletin No. 17. Of the 44, the following navigation channels are definitively stated by the Committee to have caused saltwater intrusion after construction: Moriches Inlet, New York, Mississippi RiverGulf Outlet, Louisiana, and Calcasieu River and Pass, Louisiana (USACE, 1971). The Gulf Intracoastal Waterway (GIWW) has probably caused saltwater intrusion in Lake Borgne, Louisiana (Gagliano, 1973). Both the Houma navigation Canal from Cat Island pass to Houma, Terrebonne Parish, Louisiana, and the Barataria Bay Waterway in Jefferson Parish, Louisiana have caused saltwater intrusion (Gagliano, 1973). Although not specifically stated by the Committee on Tidal Hydraulics as the cause of saltwater intrusion, the Lake Washington Ship Canal, Washington, includes a saltwater basin upstream of the main lock to retard saltwater intrusion into Lake Washington (USACE, 1971). Gosselink et al., (1979) indicate that the Sabine-Neches Ship
} 
Channel has caused saltwater intrusion in the Sabine and Neches Rivers, the ship channel, and the north end of Sabine Lake, Texas, USA.

The case studies of saltwater intrusion examined by Cook and McGaw (1981) in the National Waterways Study included the Chesapeake and Delaware Bays, the Gulf Intracoastal Waterway (GIWW) West I (New Orleans to the Calcasieu River), and San Francisco Bay. Cook and McGaw (1981) concluded that there have been no documented cases of saltwater intrusion due to existing Corps of Engineers navigation projects in the Chesapeake and Delaware Bays. The Calcasieu River Salt Water Barrier and the Catfish Point Control Structure, Schooner Bayou Control Structure, Calcasieu Lock and Vermillion Lock in the Mermentau Basin were constructed to prevent saltwater intrusion from navigation channels. Saltwater intrusion due to the Houma Canal, which is a 15 -foot (4.6m)-deep by 150 -foot (45.7- $\mathrm{m}$ )-wide channel providing a direct route between the GIWW and deep water in the Gulf, has adversely impacted the city of Houma=s water supply since construction in 1962. The authors indicate that navigation channels are one of several factors which influence salinity in San Francisco Bay/Delta (Cook and McGaw, 1981); however, they did not distinguish the relative contribution of navigation channels to saltwater intrusion from other causes.

Browder and Moore (1981) summarized recent research on freshwater inflow in Florida, Louisiana and Texas estuaries. Although saltwater intrusion occurs in many of the estuaries mentioned in the summary, the authors did not specifically tie it to navigation channels. In the case of Apalachicola Bay, however, they state that tongues of high-salinity water often extend into the bay along the bottom through passes (Livingston et al., 1974). (Browder and Moore, 1981). The passes referred to are natural deep water (Indian Pass and West Pass) and deep water due to a navigation channel (Sike=s Cut) (Livingston et al., 1974).

Hackney and Yelverton (In Press) showed that sea level rise and deepening and widening the Wilmington Harbor Federal Navigation Channel in the Cape Fear River Estuary, North Carolina, have caused saltwater intrusion.

Saltwater intrusion has occurred in the East Bay Basin, Texas, due to opening of Rollover Pass (Gosselink et al., 1979).

In a study of salinity in the Columbia River Estuary, Oregon, USA, McConnell et al. (1981) showed that during monthly neap tides (tides with decreased range) in September and October of 1977 and 1978, higher salanities extended further upstream and lasted longer than in previous studies. Freshwater inflows during the 1977 study period were considered low and during the 1978 study period were considered normal (McConnell et al., 1981). McConnell et al. (1981) indicate that deepening and widening the Columbia River Bar navigation channel in the spring and summer of 1977 could have contributed to the increased saltwater intrusion; however, the scope of the study did not involve a determination of the cause of saltwater intrusion. 


\section{References}

Brogdon, N. J., Jr., 1986. Estuary Model Test Evaluation. Waterways Experiment Station, Miscellaneous Paper HL-86-7. U.S. Army Corps of Engineers, Vicksburg, Mississippi.

Browder, J. A., and D. Moore, 1981. A New Approach to Determining the Quantitative Relationship Between Fishery Production and the Flow of Fresh Water to Estuaries. In R.D. Cross and D. L. Williams, Eds., Proceedings of the National Symposium on Freshwater Inflow to Estuaries. FWS/OBS-81/04. Vol. I, pp. 403-430.

Cook, P. And McGaw, D., 1981. National Waterways Study, Analysis of Navigation Relationships to Other Water Uses. Institute for Water Resources, U. S. Army Corps of Engineers, Fort Belvoir, Virginia.

Gagliano, S.M., 1973. Canals, Dredging and Land Reclamation in the Louisiana Coastal Zone. Hydrologic and Geologic Studies of Coastal Louisiana, Center for Wetland Resources, Louisiana State University. Report No. 14, Baton Rouge, Louisiana.

Gosselink, J.G., C.L. Cordes, and J.W. Parsons, 1979. An Ecological Characterization Study of the Chenier Plain Coastal Ecosystem of Louisiana and Texas. Vol. I. U.S. Fish and Wildlife Service, Office of Biological Services. FWS/OBS-78/9.

Hackney, C.T. and G.F. Yelverton, In Press. The Effects of Human Activities and Sea Level Rise on Wetland Ecosystems in the Cape Fear River Estuary, N.C., USA. In: Wetlands Management, Jund Publishers, Amsterdam.

Livingston, R.J., R.L. Iverson, R.H. Eastbrook, V.E. Keys and J. Taylor, Jr., 1974. Major Features of the Apalachicola Bay System: Physiography, Biota, and Resource Managment. Florida Sci., 37:245.

McConnell, R.J., G.R. Snyder, J.T. Durkin and T.H. Blahm, 1981. Concentration, Extent, and Duration of Salinity Intrusion into the Columbia River Estuary, 1977-1978. In R.D. Cross and D.L. Williams, Eds., Proceedings of the National Symposium on Freshwater Inflow into Estuaries. FWS/OBS-81/04. Vol II, pp. 41-53.

U.S. Army Corps of Engineers (USACE), 1971. Estuarine Navigation Projects, An Assembly of Information Pertaining to a Selection of Projects Having Characteristics or Problems Which Are Considered To Be of Potential Wide Interest. Committee on Tidal Hydraulics, Technical Bulletin No. 17. 


\title{
Appendix C Salinity Intrusion at Lake Washington Locks and Ship Canal Project Seattle, WA, USA
}

\author{
David A. Schuldt, P.E.
}

\section{Introduction}

The U. S. Corps of Engineers, Lake Washington Locks and Ship Canal (LWSC) project is located in the metropolitan area of Seattle, Washington. Formal name for the lock structures is Hiram M. Chittenden Locks, named after the Corps= district engineer during design of the project. Construction was accomplished between 1911-17 to provide access to and from the salt water regime of Puget Sound and the fresh water lakes of Lake Union and Lake Washington. At the time, purpose of the project was to provide for deep-draft and fishing vessels, log rafts, and other tug and barge commodities access to and from commercial facilities in Lake Union and Lake Washington. Present day lock useage is primarily recreational and commercial fishing vessels, with tug and barge transport still common, along with a few log raft make-ups and medium-draft commercial vessels. Present day lockages are highest during the late spring-early fall time period because of high recreation and commercial fishing transits. These high lockages also, unfortunately, coincide with low precipatation in the Seattle area, and the periods of high household water consumption (home, lawn, air conditioning consumption, etc.) and the need for discharge of fresh water attraction waters for andromenous salmon migrating to fresh water spawning areas, and desires to maintain high water elevations along the lake's shoreline for recreational vessel docks. Lake levels are maintained at their highest levels during summer to provide for lockage water usage, andromenous fish attraction, and reduction of saline water intrusion into the lakes. In early fall the lakes are generally lowered about two feet to prevent wind-driven wave damage along the lake's shoreline and storage for fresh water flood discharges. 
The 1900's project consisted of the locks structure, an $13 \mathrm{~km}$ ( 8 mile) long, $9 \mathrm{~m}$ (30-foot) deep navigation channel, lowering of Lake Washington about eight feet, and relocation of Cedar River discharge into Lake Washington. Photograph and project layout are shown in Figure 1 and general project features are shown in Figure 2. Location map of the LWSC project, project features of the Hiram M. Chittenden locks, and typical yearly Lake Washington hydrographic elevations are shown in Plates 1 through 5.

\section{Hydraulic/Physical Components}

The locks and spillway dam regulate the water surface elevations of the lakes tributary to the locks structure. The lakes are normally regulated at elevation $+6.10 \mathrm{~m}$ (+20 feet) to $+6.71 \mathrm{~m}$ (+22 feet) mean lower low water (MLLW) Puget Sound datum. Lake surface areas are about $90 \mathrm{sq} \mathrm{km}$ (35 square miles) and shorelines total about $144 \mathrm{~km}$ (90 miles). Fresh water inflow during summer months is usually less than 56 $\mathrm{cu} \mathrm{m} / \mathrm{s}(2,000 \mathrm{cfs})$, and as low as $28 \mathrm{cu} \mathrm{m} / \mathrm{s}(1,000 \mathrm{cfs})$ during drought years. Winter flow highs are in the 227 to $425 \mathrm{cu} \mathrm{m} / \mathrm{s}$ ( 8000 to $15,000 \mathrm{cfs}$ ) range.

Puget Sound tides are of the mixed type; i.e., two highs and lows per the 24 plus hour tidal day. Mean higher high water (MHHW) is about $3.66 \mathrm{~m}$ (+12 feet) above zero mean lower low water (MLLW); extreme tidal levels are on the order of +4.27 $\mathrm{m}(+14 \mathrm{ft})$ MLLW and $-1.22 \mathrm{~m}$ (- 4 feet) MLLW. Thus, lockage elevation differences can be as low of about $1.8 \mathrm{~m}$ (6 feet) to a maximum of about $7.92 \mathrm{~m} \mathrm{(26}$ feet). These extremes are rare, and most lockages occur with a $3.05 \mathrm{~m}(10 \mathrm{ft})$ to $3.66 \mathrm{~m}$ (12 feet) range between Puget Sound and the fresh water lakes.

As described in paragraph 1, fresh water usage and in-flow are highest and lowest, respectively, during the summer months. On inbound lockages, fresh or brackish lake water is gravity fed into the lock chamber. Because the lock is filled with Puget Sound salt water prior to filling, its salinity is on the order of 30 parts per thousand (ppt) by weight. After the Puget Sound gate closure and filling of the lock chamber with essentially brackish water, salinity values in the chamber are about $20 \mathrm{ppt}$ for filling conditions that occur at mid-tide levels. For MLLW filling conditions salinities are about $15 \mathrm{ppt}$. For filling conditions at MHHW salinities are about $25 \mathrm{ppt}$. Brackish salt water inflow to the lock chamber is from the lock walls near the concrete lock floor, and mixing within the lock chamber is essentially $100 \%$ during the filling operations. During opening of the upstream mitre gates a surface inflow of water into the lock chamber is readily apparent; this is a result of a few inches of higher lake vs. lock chamber head difference and the intrusion of denser saline water into the fresh water lake while being replaced by fresh water lake surface flow into the lock chamber.

For outbound passages to Puget Sound the lock chamber waters are semistratified as a result of the upper lock sill being $3.96 \mathrm{~m}$ (13 feet) above the lock floor and by the salt water barrier, which is normally maintained in its upright position, and is $10 \mathrm{~m}$ (33 feet) above the chamber floor. After lowering lock chamber waters to the Puget Sound tide level, the lower mitre gate is opened, vessels exit the 
chamber, and then the remaining lock chamber water is essentially intruded and replaced by denser Puget Sound saline waters.

\section{Salinity Control Measures}

During the critical summer low fresh water inflow period to Lake Washington a number of measures have been/are employed to minimize or prevent salt intrusion into Lake Washington. Operating criteria is for a maximum of one ppt salinity at the $9 \mathrm{~m}$ (30-foot) deep Montlake Cut channel, located about four miles above the locks.

Salt water intrusion control measures include the following:

a. Relatively high fresh water discharge out of Lake Washington.

$b$. Use of the small lock as much as possible, and delaying large lockage use until sufficient numbers of vessels occupy the lock chamber.

c. The salt water scavenging drain just upstream of the locks.

d. Maintaining the salt water barrier structure in its upright condition, and

e. Mini-flushing of the lock chamber on eastbound lockages.

These measures are described below.

\section{Measure 1}

During winter, high flow discharge holds back intrusion of salt water and also flushes saline waters that have accumulated in deeper water sinks above the locks. During low summer flow, salt water intrudes up the channel and most then sinks to the deeper waters of Lake Union. Once the deeper waters of Lake Union are replaced by saline waters the intrusion continues further up the canal. Critical to project operation is to prevent intrusion of salinities greater than one ppt at the Montlake Cut channel and into the very deep Lake Washington where salt would sink and essentially accumulate without bottom flushing action. While lock operations generally prevent intrusion to the Montlake Cut channel during most years, this condition has occurred during severe droughts. Critical to halting the intrusion is the discharge of fresh water flow with sufficient velocity head to force retreat of the saline wedge. During these critical conditions, operations are closely coordinated with the Seattle Water Department. One method to mitigate the intrusion is to increase discharge from the Water Department's reservoir, which can result in restrictions on municipal use in the area. Another method is to increase 
discharge by lowering Lake Washington's surface elevation to provide necessary outflow through the Montlake Cut channel. A third method is to curtail use of lockages until there are sufficient vessels to essentially fill the lock chamber. This operation saves use of fresh water infilling of the locks and also reduces the volume of salt intrusion above the locks. These alternatives are all carefully and thoroughly coordinated with the Seattle Water Department, environmental agencies, and the general public prior to any implementation.

\section{Measure 2}

Use of the small lock is routinely performed as often as possible because of its relatively small water use volume compared to that of the large lock. The small lock is $9.14 \mathrm{~m}$ (30-foot) wide, 45.72 (150-foot ) long with a floor elevation of $4.9 \mathrm{~m}$ (16 feet) MLLW. It requires about $1 / 30$ th of the volume of water required for filling the large locks chamber. The upper sill elevation of the small lock is at $+1.22 \mathrm{~m} \mathrm{(+}$ 4 feet) MLLW. Use of this lock is ideal for recreation and most fishing vessels: salt water intrusion is basically insignificant compared to the large locks and

filling/emptying times are only about five minutes compared to about 15-20 minutes for the large locks. The small locks transit about 60 percent of some 75,000 vessels per year and use of the small lock is significant in that use of the large lock is reduced; and the salt volume intrusion, fresh water filling volume, and lockage times are greatly reduced. For purposes of this report, salt water intrusion and fresh water usage for the small lock is so relatively small compared to the large locks that the small locks factors are not considered in further discussions. What must be kept in mind, however, is that without the small lock structure, the large lock would often be required to transit only a few small vessels at a time. For purposes of this report, salt water intrusion and fresh water usage of the small locks is not considered further.

\section{Measure 3}

Incorporated in the original construction of the locks was a salt water scavenging drain. A $610 \mathrm{~m}$ (2,000-foot) long and $61 \mathrm{~m}$ (200-foot) wide sump channel with a $3.72 \mathrm{sq} \mathrm{m}$ (40 square foot) intake culvert was originally constructed. Invert of the culvert is at $-9.14 \mathrm{~m}$ (-30 feet) MLLW and water is then discharged into Puget Sound waters via a $213 \mathrm{~m}$ (700-foot) long, $2.8 \mathrm{sq} \mathrm{m}$ (30 square feet) culvert. To reduce intake velocities, which resulted in draw-in of mid and upper surface less saline waters, the U.S. Army, Committee on Tidal Hydraulics (CTH) recommended enlarging the culvert intake area and adding a cover structure over the intake to increase the discharge of higher salt water content water in lieu of that partially diluted from the intake of mid and upper surface waters. The scavenging culvert intake was increased to $17.1 \mathrm{sq} \mathrm{m}$ (184 square feet) in the mid-1960's and its intake lowered a few feet; however, the lid cover has not been constructed. Increasing the culvert intake area has reduced its velocity from about seven to two feet per second; this reduction significantly increasing the outflow percentage of salt water discharge. 
As a fish and water conservatory measure, a pipe diversion from the salt water drain was installed and diverted into the fish ladder for upstream migrating salmon attraction. The salt water drain is generally open 24-hours per day throughout the year and is the largest use of water from above the locks, generally surpassing lock usage by factor of about two-to-three, about 2 to $3.7 \mathrm{cu} \mathrm{m} / \mathrm{s}(70-130 \mathrm{cfs})$ for lockages during winter and summer, to about 8.5 to $9.3 \mathrm{cu} \mathrm{m} / \mathrm{s}$ (300 - $330 \mathrm{cfs})$ for the salt water drain during winter and summer, respectively. Fish water attraction water diverted from the salt-water drain system is only about 10 percent of the salt water scavenging drain system.

\section{Measure 4}

The salt-water barrier for the large lock was originally constructed in 1966. The barrier consists of a 46 metric tons (42-ton) hollow, welded steel structure, $24.4 \mathrm{~m}$ ( 80 -foot) wide by $6.1 \mathrm{~m}$ (20-foot) high, and is $6.7 \mathrm{~m}$ ( 22 -foot) thick. The structure is divided into 16 buoyancy compartments by steel plating arranged in two horizontal rows across the width of barrier and vertically into $3 \mathrm{~m}$ (10-foot) spacings by steel plates. The barrier is hinged to the lock sill floor by five bearing pedestals. The barrier is raised / lowered by injecting air into the chambers and forcing water out; or vice versa, allowing flooding of the chambers to lower the barrier. Barrier details are shown on Plate 4 . The barrier is generally operated in the upright position as deeper-draft vessels or tows with chain are now relatively infrequent. With its elevation of $1.2 \mathrm{~m}$ (4 ft) MLLW, lowering of the barrier is seldom required as vessel drafts rarely exceed $4.5 \mathrm{~m}$ (15 feet).

When the upper mitre gates are opened for inbound passages the barrier acts as a physical obstacle to intrusion of the lower depth lock chamber saline waters. Upon opening of the mitre gate, salt water within the chamber is generally on the order of $20 \mathrm{ppt}$, and is well-mixed both vertically and horizontally. What the barrier does is essentially minimize the salt water intrusion/fresh water inflow layer into the lock chamber to an $5.5 \mathrm{~m}$ (18-foot) layer compared to $11 \mathrm{~m}$ (36 feet) without the barrier. Thus, with the barrier in an upright condition, the two-layer interchange of fresh and salt water is decreased by one-half, and overall should result in a 50 percent volume decrease of salt water intrusion to the lakes. Upon leaving the lock chamber, the denser salt water sinks into the above-locks deep scavenging channel, most of which is intercepted at the drain inlet and discharged to Puget Sound waters. The denser salt water that does escape the scavenging drain does then progress upstream as a low bottom wedge of saline waters.

Salinity measurements are taken at a number of locations along the fresh water canal. The first is at the upstream nose pier of the large lock. May 1999 surface to bottom salinities are shown in Figure 3. Sensor A represents readings taken $0.6 \mathrm{~m}$ (2 feet) above bed and sensor D represents readings taken $0.6 \mathrm{~m}$ ( 2 feet) below water surface. Comparing daily logs of tidal heights, barrier in its up or down position at times of lockage, the salinity peaks along the bottom "spike" when the barrier is in the down position, and to some extent when lockages occur at high tide when filling of the lock chamber requires a lesser volume of fresh water. Immediately upstream of the lock, low bottom salinties are on the order of 12-20 ppt with the barrier down. When in its upright position these salinities are only on the order of 5-10 ppt. 
The barrier at the LWSC project has shown to be an effective deterrent to salt water intrusion of the upstream fresh water regime. It has been operational for about 30 years and is an integral operational method to reduce salt water intrusion.

\section{Measure 5}

Mini-flushing of the large lock chamber was begun and tested about 1990 to supplement other measures in preventing excessive salt water propogation during drought years. The mini-flushing is only employed on inbound transits, and two methods of mini-flushing were tested, both with the upstream barrier in its raised position.

The first method is the "pre-lockage mini-flushing" and has been used for a number of years. In this method, inbound vessels are brought into the lock chamber and the Puget Sound mitre gates closed. Salt water is flushed from inside the chamber by opening both the above lock intake and below lock emptying culverts. During the first five minutes, little salinity decrease was noted in the lock chamber as water drawn into the lock was of relatively high saline values as a result of previous lockages; and only after additional flushing, was a significant lowering of lock salinity noted in the lock chamber. Upon closing the Puget Sound discharge gate, raising the lock chamber waters to lake levels, and opening the upbound mitre gates, only small reductions of salinity were observed in the upstream 30-foot channels.

The second method tested is the "post-lockage mini-flushing". This consists of closing the Puget Sound mitre gate, raising the water level of the lock chamber, and then beginning the "post-lockage mini-flushing" operation. Once the chamber is filled, the upstream intake valves are closed, and the lake mitre gates as well as the Puget Sound culvert discharge valves are opened. These latter steps flush salt water from the lower levels of the lock chamber as fresher water enters the chamber, and significant salt water decreases in the chamber resulted during five minutes of flushing. Salinities in the upstream channels were also significantly reduced by this operations. Only two-to-five minutes of flushing with the Puget Sound valves open are required to significantly reduce salt intrusion above the locks. Salinity intrusion increased during curtailment of the operation in early August of 1992 (a drought year), but decreased significantly when this operational practice was again implemented two weeks later.

The "post-lockage mini-flushing" was clearly determined to be efficient in preventing salt intrusion and requiring less fresh water useage than the previously described "pre-lockage mini-flushing." 


\section{Field Data}

In their paper entitled "Occurrence and control of salt intrusion through navigation locks", Long et al, (1957) have reported field data on salinity measurements conducted at the Chittenden Locks in Lake Washington Ship Canal. They have reported on the removal of salt water from the fresh water, which was achieved by flushing through a sluice at the lock. The following conclusions were drawn from the field measurements:

a. Flushing through sluice was remarkably effective. The sluice effluent consisted of approximately two parts water and one part salt. It was necessary to use fresh water equivalent to 41 percent of the lock volume measured between the upper sill and pool water levels.

$b$. There was a rational relationship between the amount of salt intrusion through lock gate and the time the gate is opened.

c. Salt intrusion is a function of dilution and degree of mixing attained in the lock, and relative elevations of floor, sill and pool surface. These factors reduce the salt intrusion potential through the upper gates to 75 percent of the potential at the lower gates.

\section{Summary and Conclusions}

Puget Sound salt water intrusion into Lake Washington is a serious problem during low-flow summer fresh water discharges. If the wedge of salt water does enter Lake Washington, the denser water will sink into its deep water, stagnating bottom waters and depleting its dissolved oxygen content. Determining the discharge uses of fresh water for lockage use, fresh water requirements for the metropolitan area of Seattle, and conservancy of andromenous fish are the important issues related to prevention of salt intrusion in Lake Washington.

The critical, low fresh water inflow period is closely monitored, both with salinity value measurements upstream of the locks and available fresh water discharge projections; and, in perhaps the unique case of the Pacific Northwest, the status of salmon production.

The intrusion of salt water into the fresh water regime is controlled through a number of operational and structural methods. Foremost are use of the salt water scavenging drain, maintaining the salt water barrier in the upright condition, and use of the small lock to prevent wedge intrusion into Lake Washington. During critical years, the potential for intrusion becomes an intensified coordination process of water/lock useage with municipal water supply authorities, environmental agencies and the general public. 


\section{References}

Long G. L., R. G. Eiland, and L. A. Mullnix, 1957, Occurrence and control of salt intrusion through navigation locks, U. S. Army Engineer Committee on Tidal Hydraulics, Paper presented at the ASCE Jackson Convention, February 1957.

Mausshardt, Sherrill and Singleton, Glen, 1995, Mitigation Salt-Water Intrusion through Hiram M. Chittenden Locks, Journal of Waterway, Port, Coastal, and Ocean Engineering, American Society of Civil Engineers, July/august 1995. 

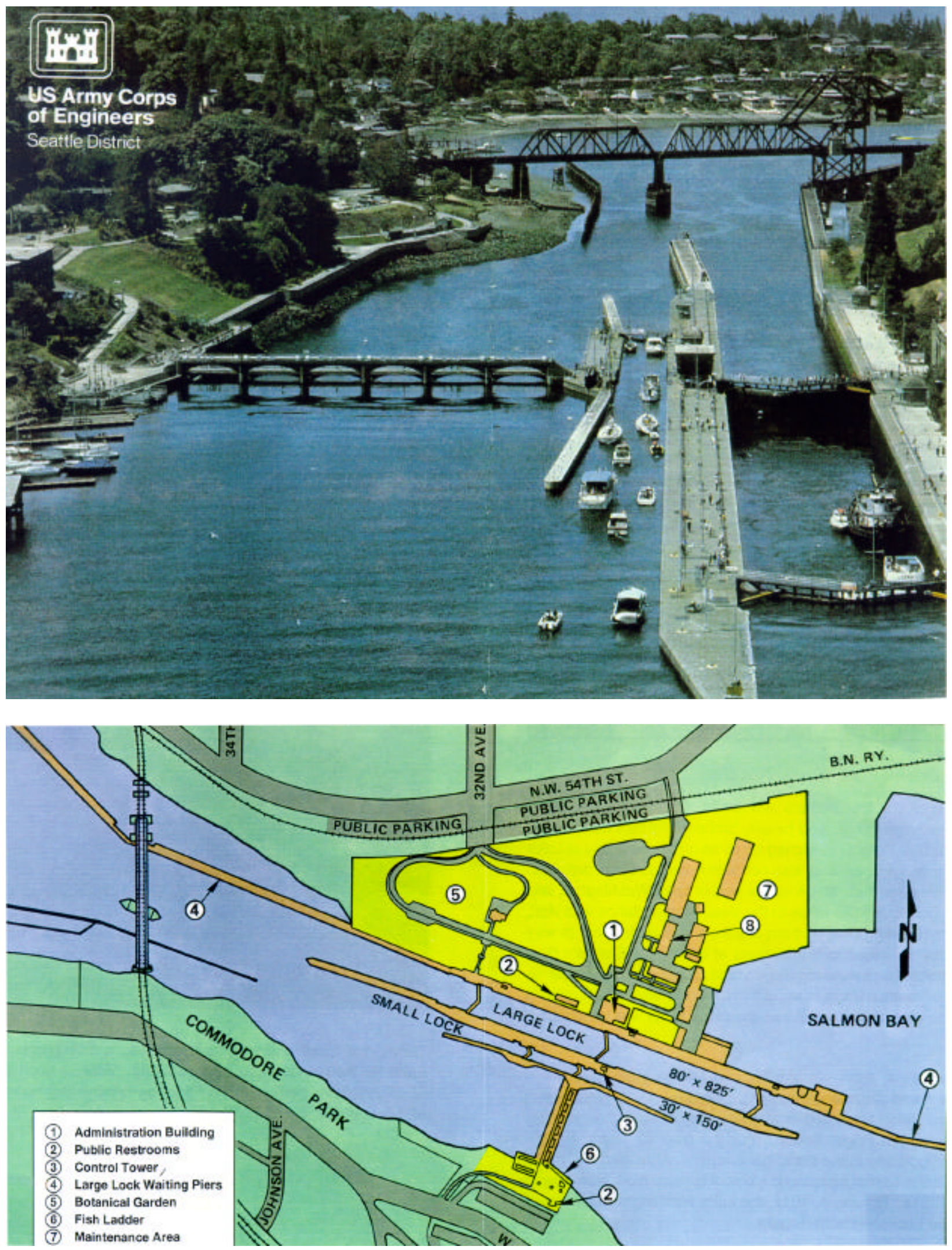

Figure $\mathrm{C} 1$. Photograph and project layout 

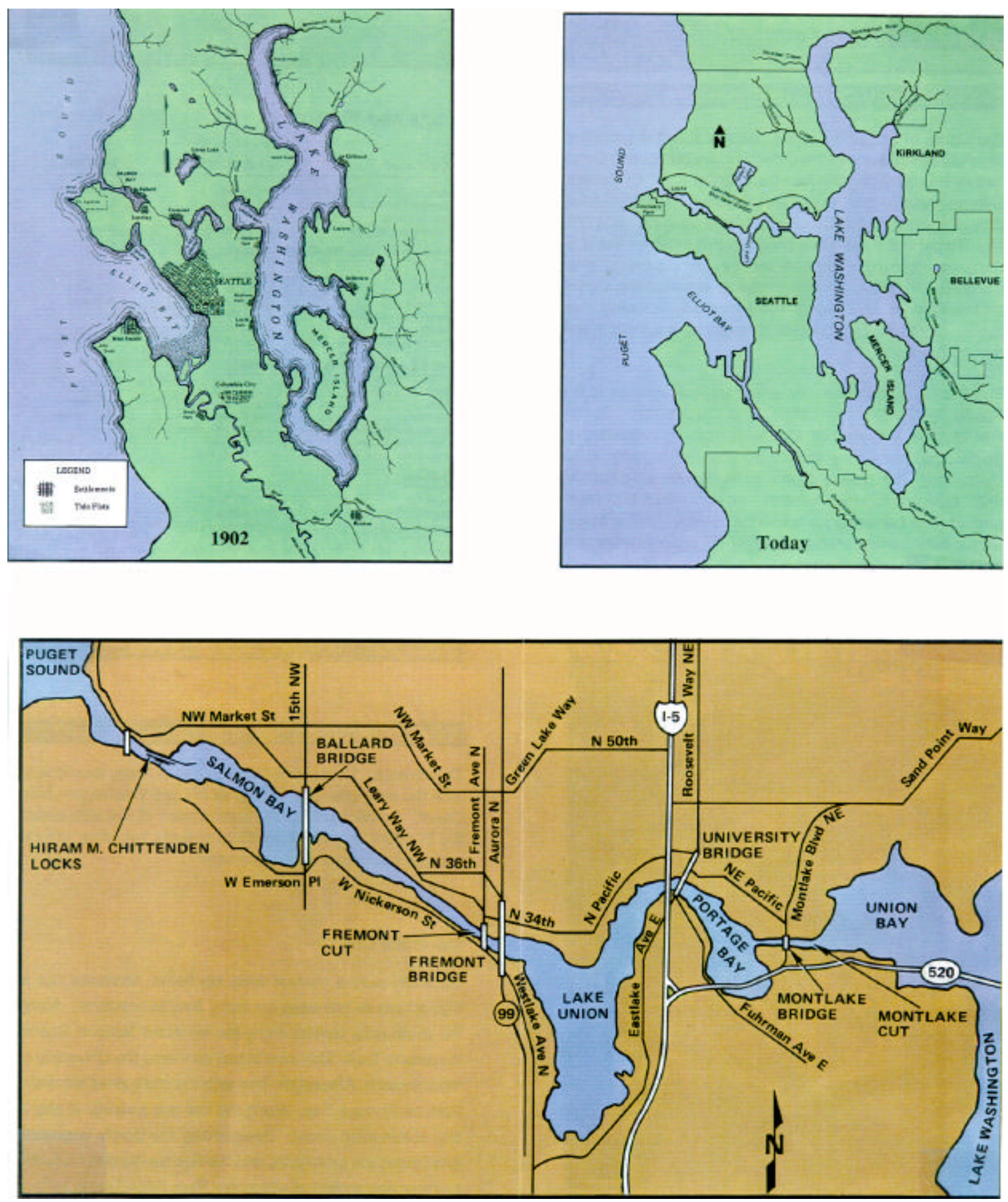

Figure C2. General project features 


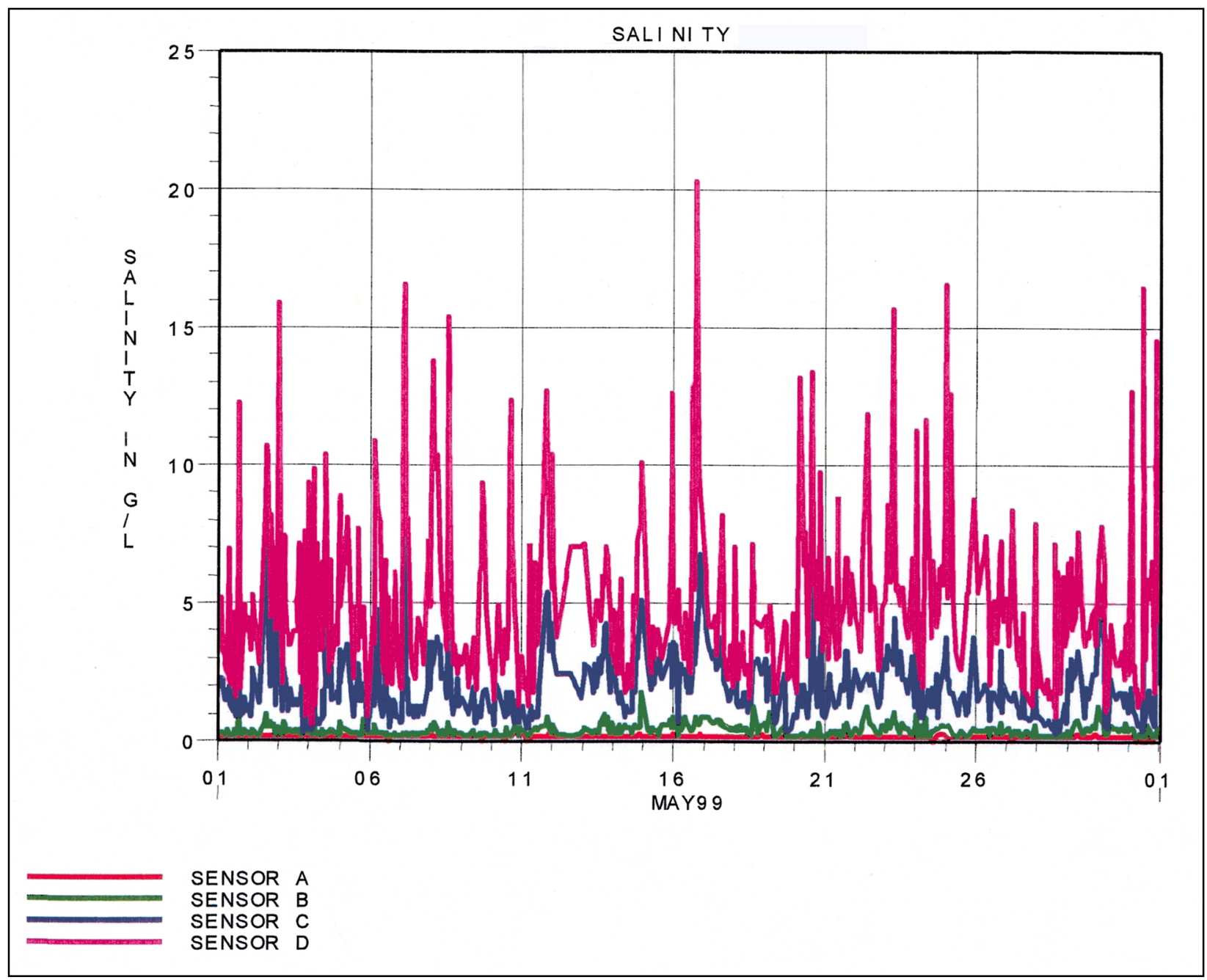

Figure C3. Field data collected in May 99 at the upstream nose pier of large Chittenden Lock 


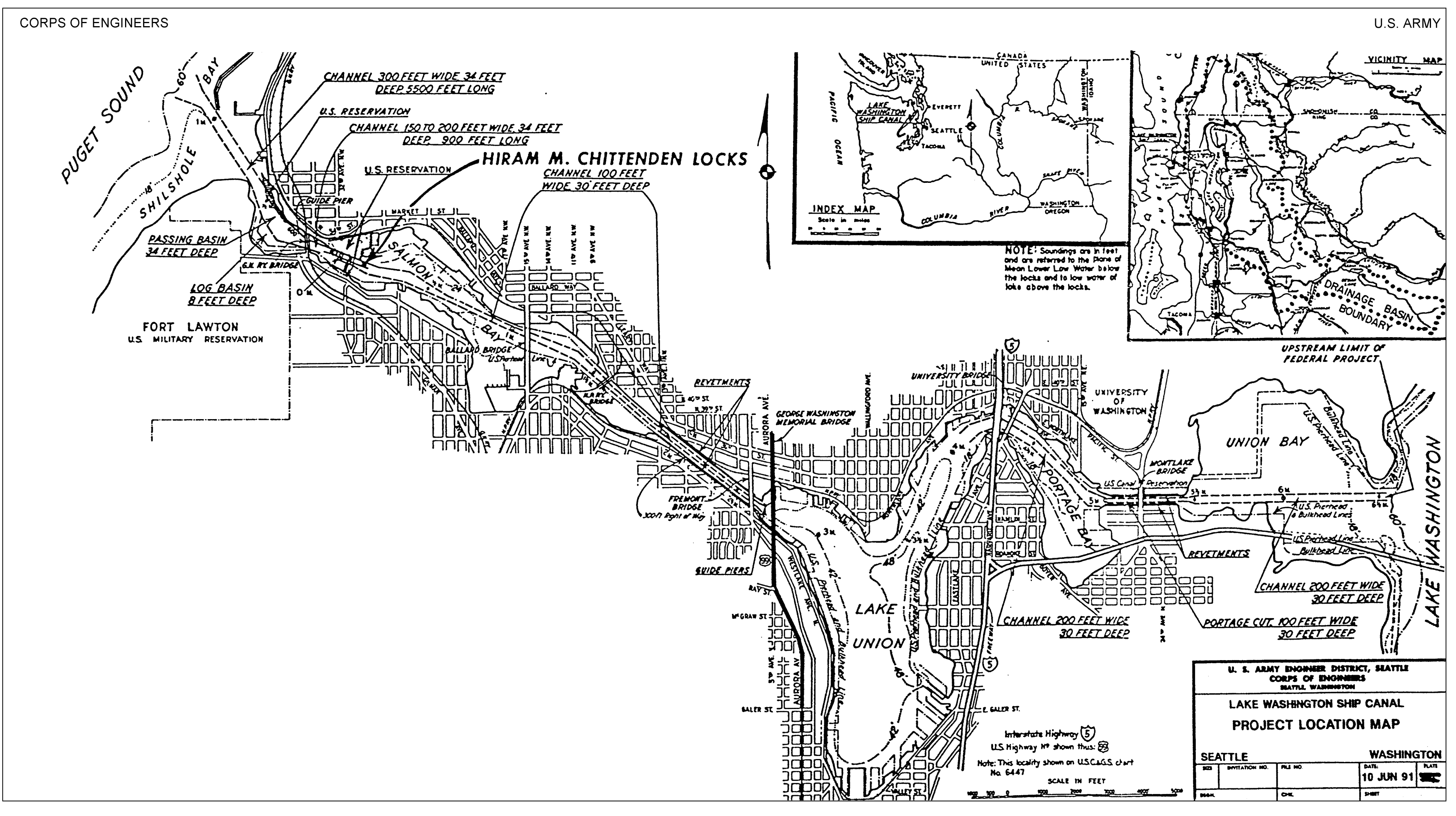

Plate 1 


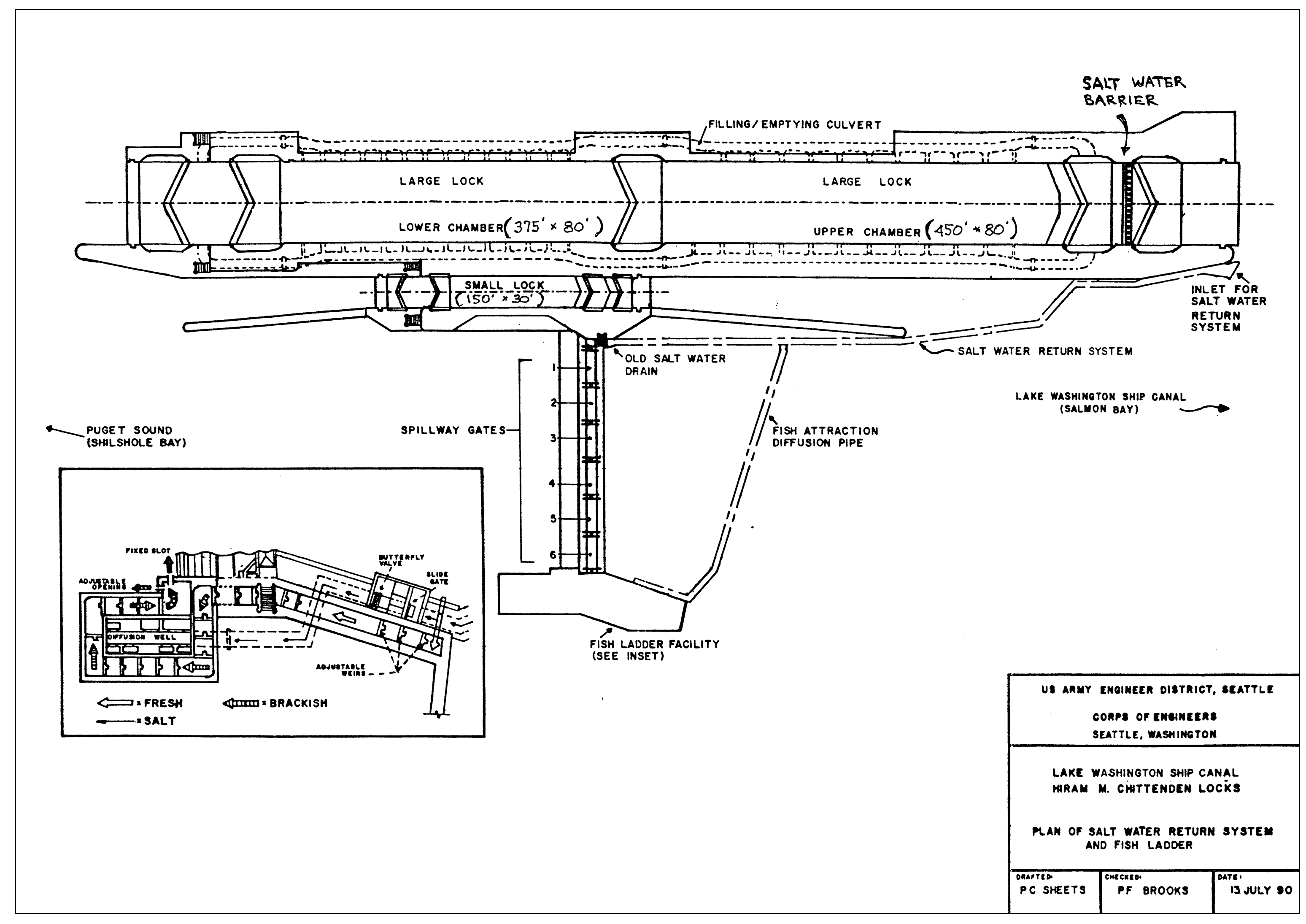

Plate 2 


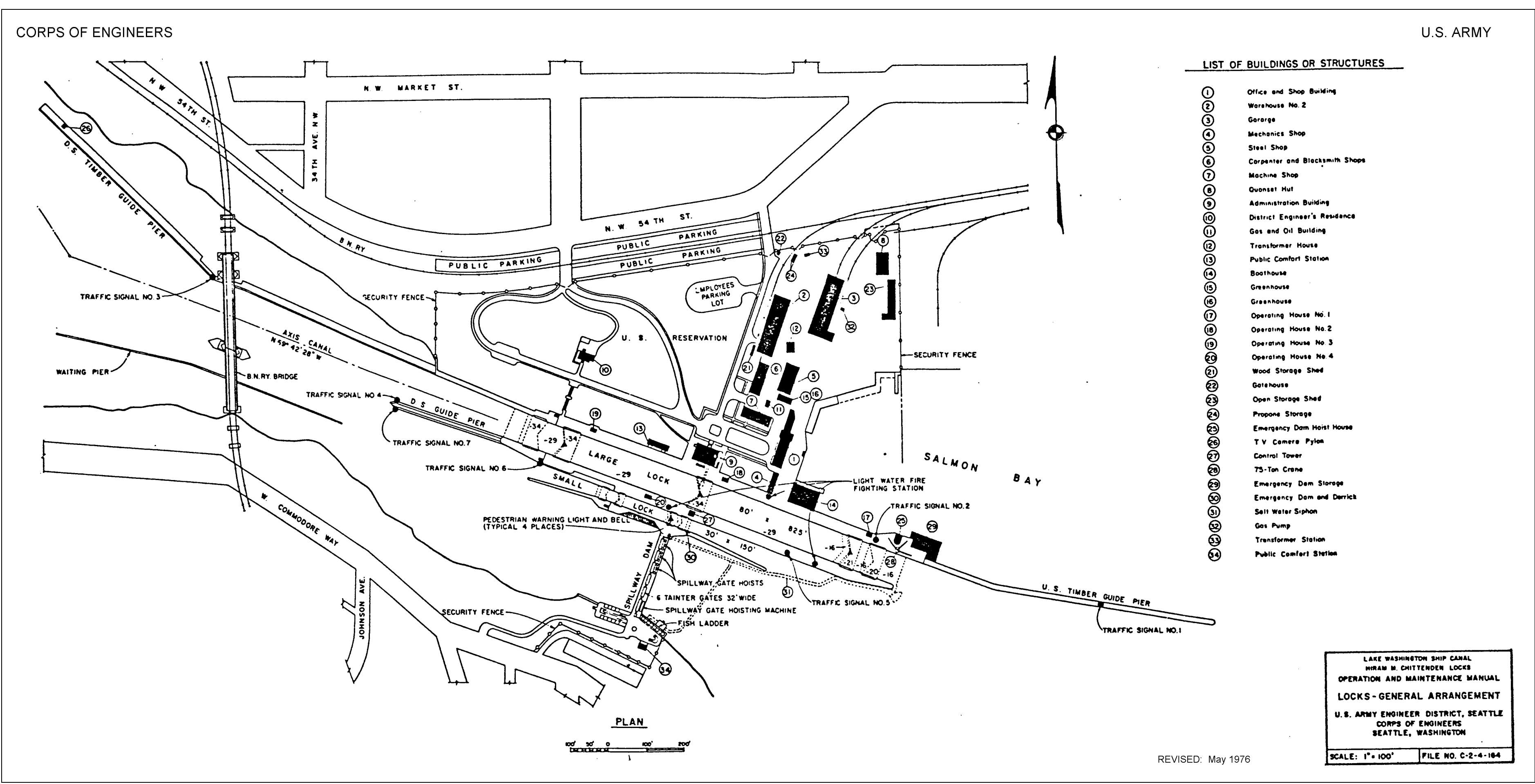




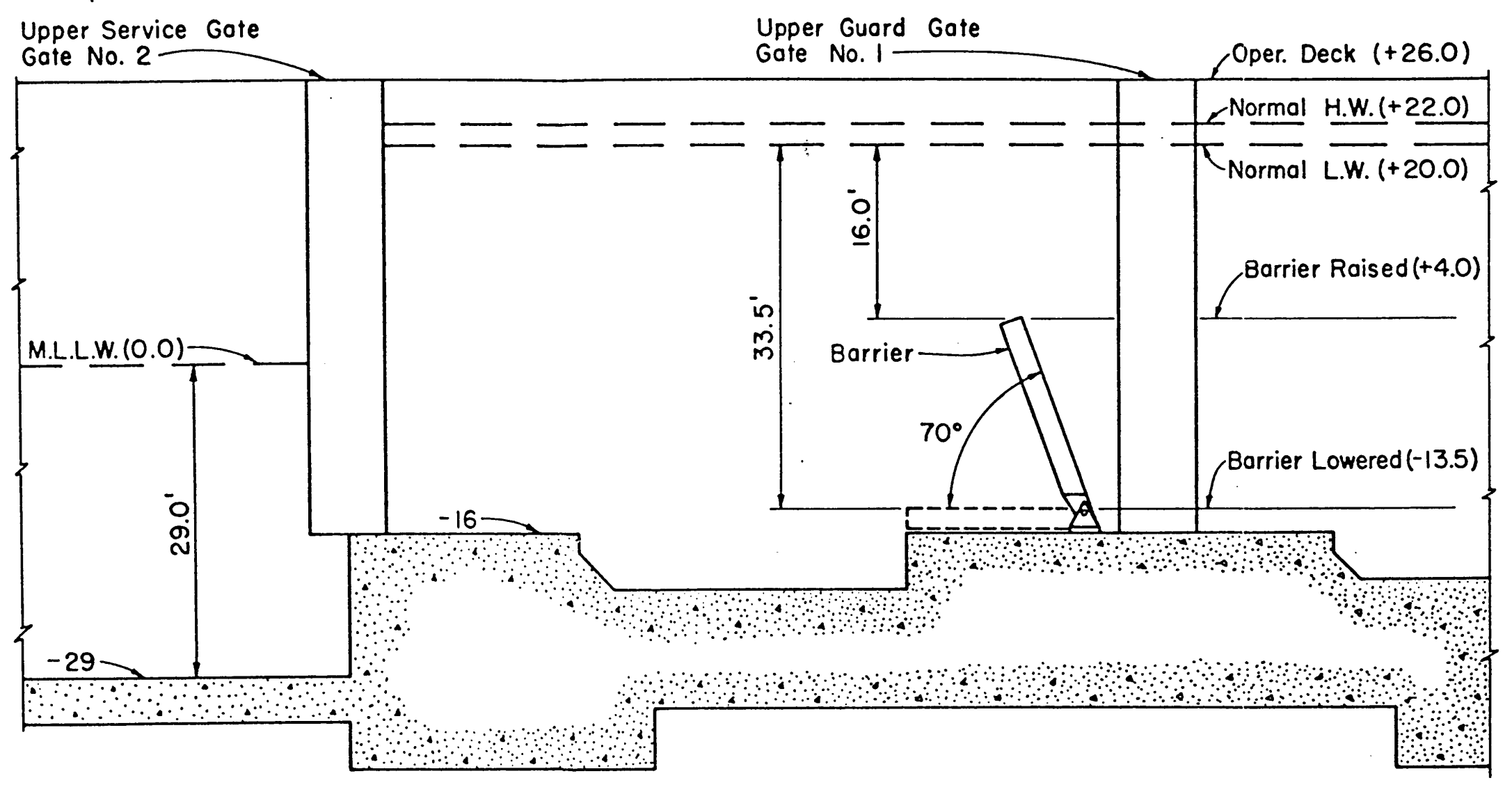

LONGITUDINAL SECTION THRU LARGE LOCK

LAKE WASHINGTON SHIP CANAL HIRAM M. CHITTENDEN LOCKS OPERATION AND MAINTENANCE MANUAL

SALT WATER BARRIER

CLEARANCE DIAGRAM

U.S. ARMY ENGINEER DISTRICT, SEATTLE

CORPS OF ENGINEERS

SCALE: $1^{\prime \prime}=10^{\prime}$

FILE NO: $0-2-4-164$ 


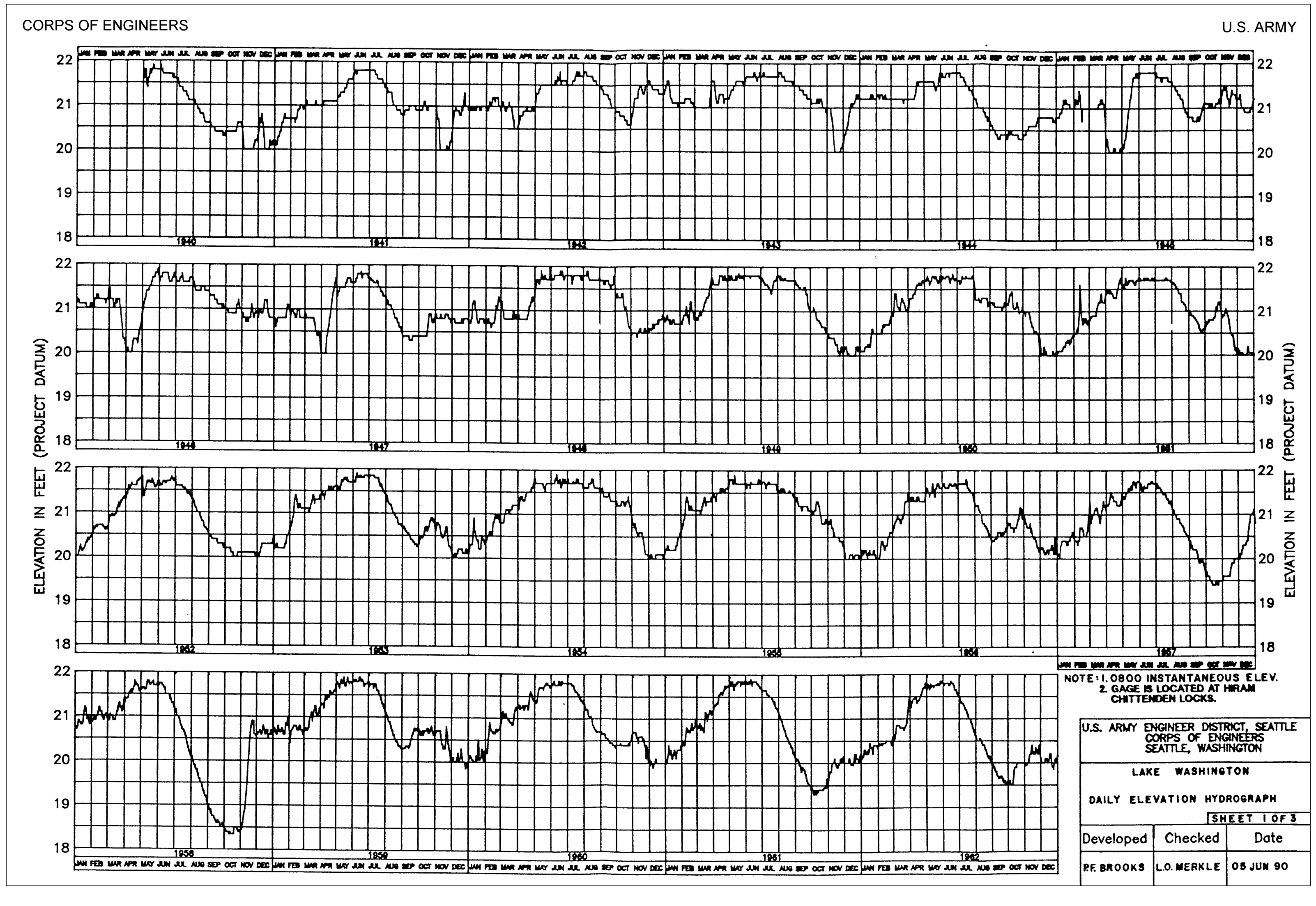

Plate 5 


\section{Appendix D The TABS-MD System}

TABS-MD is a collection of generalized computer programs and utility codes integrated into a numerical modeling system. TABS-MD is capable of one-, two-, and/or three-dimensional computations; however, only the one- and two-dimensional vertically averaged capability will be discussed in this summary. The system is used for studying hydrodynamics, sedimentation, and transport problems in rivers, reservoirs, bays, and estuaries. A schematic representation of the system is shown in Figure D1. It can be used either as a stand-alone solution technique or as a step in the hybrid modeling approach. The basic concept is to calculate water-surface elevations, current patterns, sediment erosion, transport and deposition, the resulting bed surface elevations, and the feedback to hydraulics. Existing and proposed geometry can be analyzed to determine the impact on sedimentation of project designs and to determine the impact of project designs on salinity and on the stream system. The system is described in detail by Thomas and McAnally (1985).

The three basic $2 \mathrm{D}$ depth-averaged components of the system are as follows:

a. "A Two-Dimensional Model for Free Surface Flows," RMA2.

b. "Sediment Transport in Unsteady 2-Dimensional Flows, Horizontal Plane," STUDH.

c. "Two-Dimensional Finite Element Program for Water Quality," RMA4.

RMA2 is a finite element solution of the Reynolds form of the Navier-Stokes equations for turbulent flows. Friction is calculated with Manning's equation and eddy viscosity coefficients are used to define the turbulent exchanges. A velocity form of the basic equation is used with side boundaries treated as either slip or static. The model has a marsh porosity option as well as the ability to automatically perform wetting and drying. Boundary conditions may be watersurface elevations, velocities, discharges, or tidal radiation. 


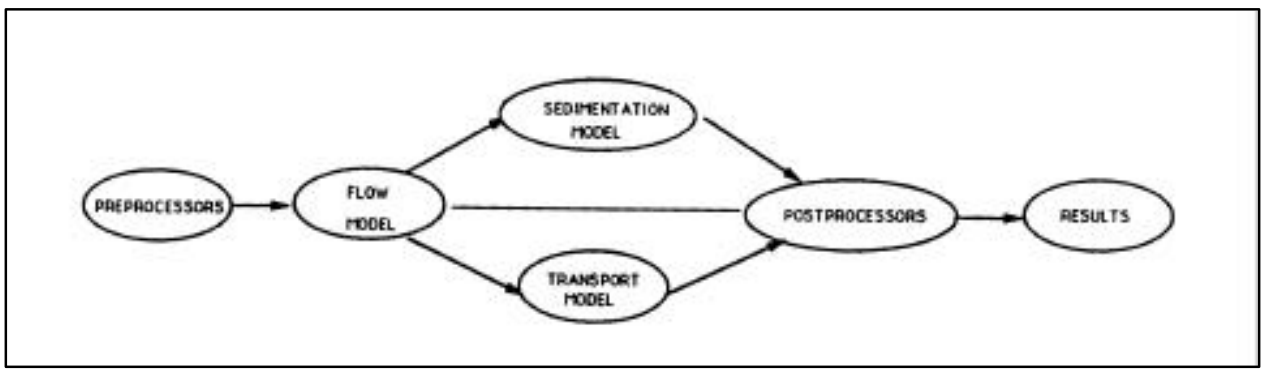

Figure D1. TABS-MD schematic

The sedimentation model, STUDH, solves the convection-diffusion equation with bed source-sink terms. These terms are structured for either sand or cohesive sediments. The Ackers-White (1973) procedure is used to calculate a sediment transport potential for the sands from which the actual transport is calculated based on availablity. Clay erosion is based on work by Partheniades (1962) and Ariathurai and the deposition of clay utilized Krone's equationns (Ariathurai, MacArthur, and Krone 1977). Deposited material forms layers and bookkeeping allows up to 10 layers at each node for maintaining separate material types, deposit thickness, and age. The code uses the same mesh as RMA2.

Salinity calculations, RMA4, are made with a form of the convectivediffusion equation which has general source-sink terms. Up to six conservative substances or substances requiring a decay term can be routed. The code uses the same mesh as RMA2. The model accommodates a mixing zone outside of the model boundaries for estimation of retrainment.

Each of these generalized computer codes can be used as a stand-alone program, but to facilitate the preparation of input data and to aid in analyzing results, a family of utility programs was developed for the following purposes:

\section{a. Digitizing}

b. Mesh generation

c. Spatial data management

d. Graphical output

e. Output analysis

f. File management

g. Interfaces

h. Job control language 


\section{Finite Element Modeling}

The TABS-MD numerical models used in this effort employ the finite element method to solve the governing equations. To help those who are unfamiliar with the method to better understand the system, a brief description of the method is given here.

The finite element method approximates a solution to governing equations by dividing the area of interest into smaller subareas, which are called elements. The dependent variables (e.g., water-surface elevations and sediment concentrations) are approximated over each element by continuous functions which interpolate based on unknown point (node) values of the variables. An error, defined as the deviation of the governing equations using the approximate solution from the equation using the correct solution, is minimized. Then, when boundary conditions are imposed, a set of solvable simultaneous equations is created. The solution is continuous over the area of interest.

In one-dimensional problems, elements are line segments. In twodimensional problems, the elements are polygons, usually either triangles or quadrilaterals. Nodes are located on the edges of elements and occasionally inside the elements. The interpolating functions may be linear or higher order polynomials. Figure D2 illustrates a quadrilateral element with eight nodes and a linear solution surface where $\mathrm{F}$ is the interpolating function.

Most water resource applications of the finite element method use the Galerkin method of weighted residuals to minimize error. In this method the residual, the local error in the equations use of the approximate and solution, is weighted by a function that is identical to the interpolating function and then minimized. Minimization results in a set of simultaneous equations in terms of nodal values of the dependent variable (e.g. water-surface elevations or sediment concentration). The time portion of time-dependent problems can be solved by the finite element method, but it is generally more efficient to express derivatives with respect to time in finite difference form.

\section{The Hydrodynamic Model, RMA2}

\section{Applications}

This program is designed for far-field problems in which vertical accelerations are negligible and the velocity vectors at a node generally point in the same directions over the entire depth of the water column at any instant of time. It expects a vertically homogeneous fluid with a free surface. The model will define the response to a specified horizontally inhomogeneous fluid. Both steady and unsteady state problems can be analyzed. A surface wind stress can be imposed and the effects of the earth's rotation can be included. 


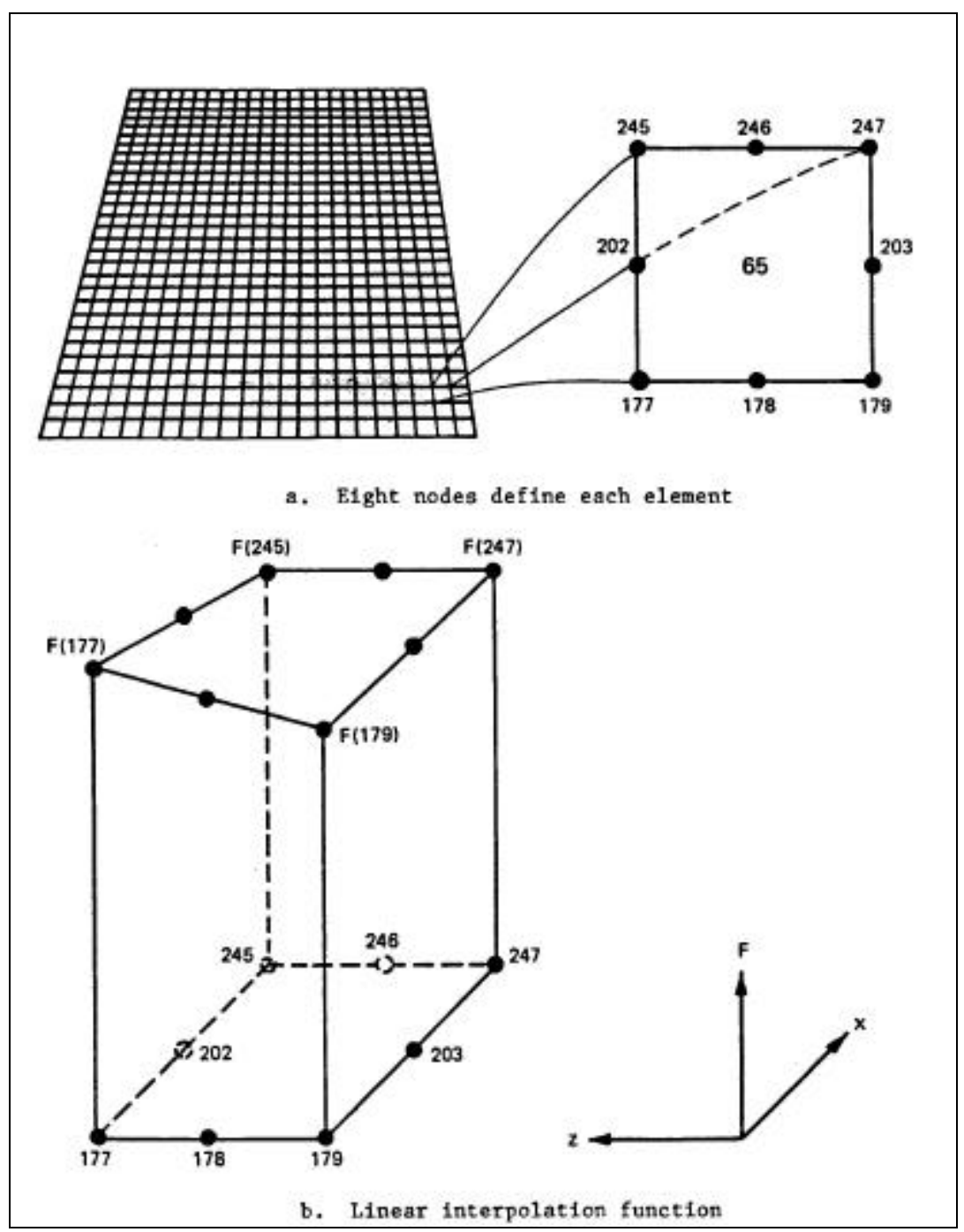

Figure D2. Two-dimensional finite element mesh

The program has been applied to calculate water levels and flow distribution around islands; flow at bridges having one or more relief openings, in contracting and expanding reaches, into and out of off-channel hydropower plants, at river junctions, and into and out of pumping plant channels; circulation and transport in waterbodies with wetlands; and general water levels and flow patterns in rivers, reservoirs, and estuaries.

\section{Limitations}

This program is not designed for near-field problems where flowstructure interactions (such as vortices, vibrations, or vertical accelerations) are of interest. Areas of vertically stratified flow are beyond this program's capability unless it is used in a hybrid modeling approach. It is two-dimensional in the horizontal 
plane, and zones where the bottom current is in a different direction from the surface current must be analyzed with considerable subjective judgment. It is a free-surface calculation for subcritical flow problems.

\section{Governing equations}

The generalized computer program RMA2 solves the depth-integrated equations of fluid mass and momentum conservation in two horizontal directions. The form of the solved equations is

$$
\begin{gathered}
h \frac{\partial u}{\partial t}+h u \frac{\partial u}{\partial x}+h u \frac{\partial u}{\partial y}-\frac{h}{\rho}\left(\varepsilon_{x x} \frac{\partial^{2} u}{\partial x^{2}}+\varepsilon_{x y} \frac{\partial^{2} u}{\partial y^{2}}\right)+g h\left(\frac{\partial a}{\partial x} \frac{\partial h}{\partial x}\right)+ \\
\frac{\text { gun }}{\left(1.48 h^{1 / 6}\right)^{2}}\left(u^{2}+v^{2}\right)^{1 / 2}-\zeta V_{a}^{2} \cos \varphi-2 h \omega v \sin \phi=0 \\
h \frac{\partial v}{\partial t}+\mathrm{h} v \frac{\partial v}{\partial x}+\mathrm{h} v \frac{\partial \mathrm{v}}{\partial \mathrm{y}}-\frac{h}{\rho}\left(\varepsilon_{y x} \frac{\partial^{2} v}{\partial y^{2}}+\varepsilon_{y y} \frac{\partial^{2} v}{\partial y^{2}}\right)+g h\left(\frac{\partial a}{\partial y}+\frac{\partial H}{\partial y}\right)+ \\
\frac{g u n}{\left(1.48 H^{1 / 6}\right)^{2}}\left(u^{2}+\mathrm{v}^{2}\right)^{1 / 2}-\zeta \mathrm{V}_{\mathrm{a}}^{2} \sin \varphi+2 \omega h u \sin \phi=0 \\
\frac{\partial h}{\partial t}+h\left(\frac{\partial u}{\partial x}+\frac{\partial v}{\partial y}\right)+u \frac{\partial h}{\partial x}+v \frac{\partial h}{\partial y}=0
\end{gathered}
$$

where

$\begin{array}{lll}h & = & \text { depth } \\ u, v & = & \text { velocities } \\ x, y, t & = & \text { Cartesian coordinates and time } \\ \mathrm{D} & = & \text { density of fluid } \\ , & = & \text { eddy viscosity coefficient, for } \mathrm{xx}=\text { normal direction on x-axis } \\ & & \begin{array}{l}\text { surface; yy= normal direction on y-axis surface; } \mathrm{xy} \text { and } \mathrm{yx}= \\ \text { shear direction on each surface }\end{array} \\ g & = & \text { acceleration due to gravity } \\ a & = & \text { elevation of bottom } \\ n & = & \text { Manning's n value } \\ 1.486 & = & \text { conversion from SI (metric) to non-SI units } \\ \cdot & = & \text { empirical wind shear coefficient } \\ V_{a} & = & \text { wind speed } \\ \mathrm{R} & = & \text { wind direction } \\ \mathrm{T} & = & \text { rate of earth's angular rotation } \\ \mathrm{N} & = & \text { local latitude }\end{array}$


Equations D1, D2, and D3 are solved by the finite element method using Galerkin weighted residuals. The elements may be one-dimensional lines or twodimensional quadrilaterals or triangles and may have curved (parabolic) sides. The shape functions are quadratic for velocity and linear for depth. Integration in space is performed by Gaussian integration. Derivatives in time are replaced by a nonlinear finite difference approximation. Variables are assumed to vary over each time interval in the form

$$
f(t)=f(0)+a t+b t^{c} \quad t_{o} \leq t<t
$$

which is differentiated with respect to time, and cast in finite difference form. Letters $a, b$, and $c$ are constants. It has been found by experiment that the best value for $c$ is 1.5 (Norton and King 1977).

The solution is fully implicit and the set of simulataneous equations is solved by Newton-Raphson non lineaarr iteration. The computer code executes the solution by means of a front-type solver that assembles a portion of the matrix and solves it before assembling the next portion of the matrix. The front solver's efficiency is largely independent of bandwidth and thus does not require as much care in formation of the computational mesh as do earlier traditional solvers.

The code RMA2 is based on the earlier versions (Norton and King 1977) but differs in several ways. It is formulated in terms of velocity (v) instead of unit discharge (vh), which improves some aspects of the code's behavior; it permits drying and wetting of areas within the grid; it permits specification of turbulent coefficients in directions other than along the $\mathrm{x}$ - and z-axes; it accommodates the specifications of hydraulic control structures in the network; it permits wetlands to be simulated as either totally wet/dry or as gradually changing wetting and it permits input in either English or system international units. For a more complete description, see Appendix F of Thomas and McAnally (1985).

\section{The Sediment Transport Model, STUDH}

\section{Applications}

STUDH can be applied to clay and/or sand bed sediments where flow velocities can be considered two-dimensional (i.e., the speed and direction can be satisfactorily represented as a depth-averaged velocity). It is useful for both deposition and erosion studies and, to a limited extent, for stream width studies. The program treats two categories of sediment: noncohesive, which is referred to as sand here, and cohesive, which is referred to as clay.

\section{Limitations}

Both clay and sand may be analyzed, but the model considers a single, effective grain size for each and treats each separately. Fall velocity must be prescribed along with the water-surface elevations, $x$-velocity, y-velocity, 
diffusion coefficients, bed density, critical shear stresses for erosion, erosion rate constants, and critical shear stress for deposition.

The program does not compute water-surface elevations or velocities; therefore these data must be provided. For complicated geometries, the numerical model for hydrodynamic computations, RMA2, is used. However, STUDH can only accept a two-dimensional network.

\section{Governing equations}

The generalized computer program STUDH solves the depth-integrated convection-dispersion equation in two horizontal dimensions for a single sediment constituent. For a more complete description, see Appendix G of Thomas and McAnally (1985). The form of the solved equation is

$$
\frac{\partial C}{\partial t}+u \frac{\partial C}{\partial x}+v \frac{\partial C}{\partial y}=\frac{\partial}{\partial x}\left(D_{x} \frac{\partial C}{\partial x}\right)+\frac{\partial}{\partial y}\left(D_{y} \frac{\partial C}{\partial y}\right)+\alpha_{1} C+\alpha_{2}=0
$$

where

$C=$ concentration of sediment

$u=$ depth-integrated velocity in $\mathrm{x}$-direction

$D_{x}=$ dispersion coefficient in $\mathrm{x}$-direction

$D_{y} \quad=\quad$ dispersion coefficient in y-direction

$" 1=$ coefficient of concentration-dependent source/sink term

${ }_{2}=$ coefficient of source/sink term

The source/sink terms in Equation D5 are computed in routines that treat the interaction of the flow and the bed. Separate sections of the code handle computations for clay bed and sand bed problems.

\section{Sand transport}

The source/sink terms are evaluated by first computing a potential sand transport capacity for the specified flow conditions, comparing that capacity with the amount of sand actually being transported, and then eroding from or depositing to the bed at a rate that would approach the equilibrium value after sufficient elapsed time.

The potential sand transport capacity in the model is computed by the method of Ackers and White (1973), which uses a transport power (work rate) approach. It has been shown to provide superior results for transport under steady-flow conditions (White, Milli, nad Crabbe 1975) and for combined waves and currents (Swart 1976). Flume tests at the U.S. Army Engineer Research and Development Center, Waterways Experiment Station have shown that the concept is valid for transport by estuarine currents.

The total load transport function of Ackers and White is based upon a dimensionless grain size 


$$
D_{g r}=D\left[\frac{g(s-1)}{v^{2}}\right]^{1 / 3}
$$

where

$D=$ sediment particle diameter

$s=$ specific gravity of the sediment

$v=$ kinematic viscosity of the fluid

and a sediment mobility parameter

$$
F_{g r}=\left[\frac{\tau^{n^{\prime}} \tau^{\prime(1-n)}}{\rho g D(s-1)}\right]^{1 / 2}
$$

where

$$
\mathrm{J}=\text { total boundary shear stress }=\mathrm{Dg} R S
$$

where

$$
\begin{aligned}
& R=\text { hydraulic radius } \\
& S=\text { slope of water surface } \\
& n=\text { a coefficient expressing the relative importance of bed-load and } \\
& \text { suspended-load transport, given in Equation D9 } \\
& \text { NOTE: } \\
& n=1 \text { for fine sediments } \\
& n=0 \text { for coarse sediments } \\
& \quad \mathrm{J}=\text { boundary surface shear stress }
\end{aligned}
$$

The surface shear stress is that part of the total shear stress which is due to the rough surface of the bed only, i.e., not including that part due to bed forms and geometry. It therefore corresponds to that shear stress that the flow would exert on a plane bed.

The total sediment transport is (in $\mathrm{Kg} / \mathrm{m}^{3}$ ) expressed as an effective concentration

$$
G P=C\left(\frac{F_{g r}}{A}-1\right)^{m} \frac{s D}{h}\left(\frac{\rho}{\tau} U\right)^{n}
$$

where $U$ is the average flow speed, and for $1<\mathrm{D}_{\mathrm{gr}} \# 60$

$$
n^{\prime}=1.00-0.56 \log D_{g r}
$$




$$
\begin{gathered}
A=\frac{0.23}{\sqrt{D_{g r}}}+0.14 \\
\log C=2.86 \log D_{g r}-\left(\log D_{g r}\right)^{2}-3.53 \\
m=\frac{9.66}{D_{g r}}+1.34
\end{gathered}
$$

For $\mathrm{D}_{\mathrm{gr}}<60$

$$
\begin{gathered}
n^{\prime}=0.00 \\
A=0.17 \\
C=0.025 \\
m=1.5
\end{gathered}
$$

Note the $C_{a}$ has units consistent with $G_{p}\left(k g / m^{3}\right.$ for STUDH).

Equations D6-D16 result in a potential sediment concentrationn $G_{p}$. This value is the depth-averaged concentration of sediment that will occur if an equilibrium transport rate is reached with a nonlimited supply of sediment. The rate of sediment deposition (or erosion) is then computed as

$$
R=\frac{\mathrm{G}_{\mathrm{p}}-C}{\mathrm{t}_{\mathrm{c}}}
$$

where

$$
\begin{aligned}
& C=\text { present sediment concentration } \\
& t_{c}=\text { time constant }
\end{aligned}
$$

For deposition, the time constant is

$$
t_{c}=\text { larger of }\left\{\begin{array}{c}
\Delta t \\
o r \\
\frac{C_{d} H}{V_{s}}
\end{array}\right.
$$

and for erosion it is 


$$
t_{c}=\text { larger of }\left\{\begin{array}{c}
\Delta t \\
o r \\
\frac{C e h}{U}
\end{array}\right.
$$

where

) $t=$ computational time-step

$C_{d}=$ response time coefficient for deposition

$V_{s}=$ sediment settling velocity

$C_{e}=$ respoonse time coefficient for erosion

The sand bed has a specified initial thickness which limits the amount of erosion to that thickness.

\section{Cohesive sediments transport}

Cohesive sediments (usually clays and some silts) are considered to be depositional if the bed shear stress exerted by the flow is less than a critical value $J_{d}$. When that value occurs, the deposition rate is given by Krone's (1962) equation

$$
S=\left\{\begin{array}{l}
-\frac{2 V_{s}}{h} C\left(1-\frac{\tau}{\tau d}\right) \text { for } C<C_{c} \\
-\frac{2 V_{s}}{h C_{c}^{4 / 3}} C^{5 / 3}\left(1-\frac{\tau}{\tau d}\right) \text { for } C>C_{c}
\end{array}\right.
$$

where

$$
\begin{aligned}
& S=\text { source term } \\
& V_{s}=\text { fall velocity of a sediment particle } \\
& h=\text { flow depth } \\
& C=\text { sediment concentration in water column } \\
& \mathrm{J}=\text { bed shear stress } \\
& \mathrm{J}_{d}=\text { critical shear stress for deposition } \\
& C_{c}=\text { critical concentration }=300 \mathrm{mg} / \mathrm{R}
\end{aligned}
$$

If the bed shear stress is greater than the critical value for particle erosion $\mathrm{J}_{e}$, material is removed from the bed. The source term is then computed by Ariathurai's (Ariathurai, MacArthur, and Krone 1977) adaptation of Partheniades' (1962) findings:

$$
S=\frac{P}{h}\left(\frac{\tau}{\tau_{e}}-1\right)
$$


where $P$ is the erosion rate constant, unless the shear stress is also greater than the critical value for mass erosion. When this value is exceeded, mass failure of a sediment layer occurs and

$$
S=\frac{T_{L} P_{L}}{h \Lambda t}
$$

where

$$
\begin{aligned}
& T_{L}=\text { thickness of the failed layer } \\
& \mathrm{D}_{L}=\text { density of the failed layer } \\
& )_{t}=\text { time interval over which failure occurs } \\
& J_{s}=\text { bulk shear strength of the layer }
\end{aligned}
$$

The cohesive sediment bed consists of 1 to 10 layers, each with a distinct density and erosion resistance. The layers consolidate with overburden and time.

\section{Bed shear stress}

Bed shear stresses are calculated from the flow speed according to one of four optional equations: the smooth-wall log velocity profile or Manning equation for flows alone; and a smooth bed or rippled bed equation for combined currents and wind waves. Shear stresses are calculated using the shear velocity concept where

$$
\tau b=\rho \mathbf{u}_{*}^{2}
$$

where

$$
\begin{aligned}
& \mathrm{J}_{b}=\text { bed shear stress } \\
& u_{*}=\text { shear velocity }
\end{aligned}
$$

and the shear velocity is calculated by one of four methods:

a. Smooth-wall log velocity profiles

$$
\frac{\bar{u}}{u^{*}}=5.75 \log \left(3.23 \frac{u * h}{v}\right)
$$

which is applicable to the lower 15 percent of the boundary layer when

$$
\frac{u^{*} h}{v}>30
$$

where $\dot{E}$ is the mean flow velocity (resultant of $u$ and $v$ components)

b. The Manning shear stress equation 


$$
u *=\frac{\sqrt{g^{-}}}{C M E h^{1 / 6}}
$$

where $C M E$ is a coefficient of 1 for SI (metric) units and 1.486 for non-SI units of measurement.

c. A jonsson-type equation for surface shear stress (plane beds) caused by waves and currents

$$
u^{*}=\frac{1}{2}\left(\frac{f_{w} u_{o m}+f_{c} \bar{u}}{-\bar{u}}\right)\left(\overline{\mathrm{u}}+\frac{u_{o m}}{2}\right)
$$

where

$f_{w}=$ shear stress coefficient for waves

$u_{o m}=$ maximum orbital velocity of waves

$f_{c}=$ shear stress coefficient for currents

d. A Bijker-type equation for total shear stress caused by waves and current

$$
u *=\sqrt{\frac{1}{2}} f_{c} u+\frac{1}{4} f_{w} u_{o m}^{2}
$$

\section{Solution method}

Equation D5 is solved by the finite element method using Galerkin weighted residuals. Like RMA2, which uses the same general solution technique, elements are quadrilateral and may have parabolic sides. Shape functions are quadratic. Integration in space is Gaussian. Time-stepping is performed by a CrankNicholson approach with a weighting factor (q) of 0.66. A front-type solver similar to that in RMA2 is used to solve the simultaneous equations.

\section{The Water Quality Transport Model, RMA4}

\section{Applications}

The water quality model, RMA4, is designed to simulate the depth-average advection-diffusion process in most water bodies with a free surface. The model is used for investigating the physical processes of migration and mixing of a soluble substance in reservoirs, rivers, bays, estuarines and coastal zones. The model is useful for evaluation of the basic processes or for defining the effectiveness of remedial measures. For complex geometries the model utilizes the depth-averaged hydrodynamics form RMA2. 
The water quality model has been applied to define the horizontal salinity distribution; to trace temperature effects from power plants; to calculate residence times of harbors or basins; to optimize the placement of outfalls; to identify potential critical areas for oil spills or other pollutants spread; to evaluate turbidity plume extent; and to monitor other water quality criterion within game and fish habitats.

\section{Limitations}

The formulation of RMA4 is limited to one-dimensional (cross-sectionally averaged) and two-dimensional (depth-averaged) situations in which the concentration is fairly well-mixed in the vertical. It will not provide accurate concentrations for stratified situations in which the constituent concentration influences the density of the fluid. In addition, the accuracy of the transport model is dependent on the accuracy of the hydrodynamics (e.q. as supplied from RMA2).

\section{Governing equations}

The CEERD version of RMA4 is a revised version of RMA4 as developed by King (1989). The generalized computer program solves the depth-integrated

equations of the transport and mixing process. The form of the equations solved is:

$h\left(\frac{\partial c}{\partial t}+u \frac{\partial c}{\partial x}+v \frac{\partial c}{\partial y}-\frac{\partial}{\partial x} D_{x} \frac{\partial c}{\partial x}-\frac{\partial}{\partial y} D_{y} \frac{\partial c}{\partial y}-\sigma+k c\right)=0$

where

$\begin{array}{lll}h & = & \text { water depth } \\ c & = & \text { constituent concentration } \\ t & = & \text { time } \\ u, v, & = & \text { velocity components } \\ D_{x}, D_{y} & = & \text { turbulent mixing coefficients } \\ k & = & \text { first order decay } \\ \mathrm{F} & = & \text { source/sink of constituent }\end{array}$

Note that the basic governing equation for RMA4 is the same as for the sediment transport model, STUDH. The differences between the two models lies in the source/sink terms.

Equation D29 is solved by the finite element method using Galerkin weighted residuals. As with the hydrodynamic model, RMA2, the transport model RMA4 handles one-dimensional segments or two-dimensional quadrilaterals or triangles with the option for curved sides. Spatial integration of the equation is performed by Gaussian techniques and the temporal variations are handled by nonlinear finite differences, consistent with the method described in paragraph 15 above. The frontal solution method is also used in RMA4, as with 
the other programs in the TABS-MD system, to provide an efficient solution algorithm.

The boundary conditions for RMA4 are specified in several optional ways. The boundary concentration may be specified absolutely at a certain level regardless of the flow direction; the concentration can be specified to be applied only when the water is leaving the model; or a mixing zone may be specified just beyond the model boundary to provide the possibility of reentertainment of constituent into the model that may have crossed the boundary earlier. For a more detailed description of the constituent transport model, RMA4, see King and Rachiele, 1989.

Within the one-dimensional formulation of the model, there is a provision for defining the constituent concentration mixing and transport at control structures as they may have been specified in RMA2. These allow for either a flow through condition, as for example for a wier type flow, or for a mixing chamber type of flux, which would be appropriate for a navigation lock.

\section{References}

Ackers, P., and White, W. R. 1973. (Nov). Sediment Transport: New Approach and Analysis," Journal, Hydraulics Division, American Society of Civil Engineers, Vol 99, No. HY-11, pp 2041-2060.

Ariathurai, R., MacArthur, R. D., and Krone, R. C. 1977 (Oct). "Mathematical Model of Estuarial Sediment Transport," Technical Report D-77-12, U.S. Army Engineer Waterways Experiment Station, Vicksburg, MS.

King, Ian P., and Richard Rachiele, 1989. "Program Documentation: RMA4 - A Two Dimensional Water Quality Model; Version 3.0”, Resource Management Associates, Laffayette, CA.

Krone, R. B. 1962. "Flume Studies of Transport of Sediment in Estuarial Shoaling Processes," Final Report, Hydraulics Engineering Research Laboratory, University of California, Berkeley, CA.

Norton, W. R., and King, I. P. 1977 (Feb). "Operating Instructions for the Computer Program RMA-2V," Resource Management Associates, Lafayette, CA.

Partheniades, E. 1962. "A Study of Erosion and Deposition of Cohesive Soils in Salt Water," Ph.D. Dissertation, University of California, Berkeley, CA.

Swart, D. H. 1976 (Sep). "Coastal Sediment Transport, Computation of Longshore Transport," R968, Part 1, Delft Hydraulics Laboratory, The Netherlands. 
Thomas, W. A., and McAnally, W. H., Jr. 1985 (Aug). “User's Manual for the Generalized Computer Program System; Open-Channel Flow and Sedimentation, TABS-2, Main Text and Appendices A through O," Instruction Report HL-85-1, U.S. Army Engineer Waterways Experiment Station, Vicksburg, MS.

White, W. R., Milli, H., and Crabbe, A. D. 1975. "Sediment Transport Theories: An Appraisal of Available Methods," Report Int 119, Vols 1 and 2, Hydraulics Research Station, Wallingford, England. 


\section{Appendix E Bibliography on Salt Water Intrusion in Locks}

1. Keulegan, G. H., 1957. An experimental study of the motion of saline water from locks into fresh water channels, Thirteenth progress report on model laws for density currents, National Bureau of Standards, Report No. 5168.

2. Long, G. L., Eiland, R. G., and Mullnix, L. A,. 1957. Occurrence and control on salt intrusion through navigation locks, U.S. Army Engineer Committee on Tidal Hydraulics, Paper presented at the ASCE Jackson Convention, February 1957.

3. Abraham, G., and Van Der Burgh, P., 1962. Reduction of salt water intrusion through locks by pneumatic barriers, Delft Hydraulics Laboratory, the Netherlands, Publication No. 28.

4. Committee on Tidal Hydraulics, 1963. Salt water intrusion Lake Washington ship canal, Seattle, WA, U.S. Army Corps of Engineers.

5. Abraham, G. and Van Der Burgh, P., 1964. Pneumatic reduction of salt intrusion through locks, Journal of Hydraulics Division, ASCE, vol. 90, No. HY1, 83-119.

6. Abraham, G., Van Der Burgh, P., and De Vos, P., 1965. Means to reduce salt intrusion through new and existing locks, Delft Hydraulics Laboratory, the Netherlands, Publication No. 38.

7. Ribes, G., and Blanchet, C., 1965. Les courants de densite et le projet de l'ecluse de Mardyck a dunkerque. La Houille Blanche, 20:48.

8. Boggess D. S., 1968. A test of flushing procedures to control salt-water intrusion at the W. P. Franklin Dam near Ft. Myers, Florida

9. Abraham, G., Van Der Burgh, P., and De Vos, P., 1973. Pneumatic barriers to reduce salt intrusion through locks, Riijkswaterstaat Communications No. 17. (Also Delft Hydraulics Laboratory, the Netherlands, Publication No. 126.) 
10. Kolkman, P. A. and Slagter, J. C., 1976. The Kreekrak Locks on the ScheldtRhine Connection. Rijkswaterstaat Communications No. 24. (Also Delft Hydraulic Laboratory, Publication No. 160.)

11. Monadier, P., 1981. Probleme de la remontee des eaux slees par les ecluses maritimes, example de l'ecluse de Mardyck a dunkerque. La Houille Blanche, vol. 36/2-3, 121-127.

12. Permanent International Association of Navigation Congress (PIANC), Supplement Bulletin No. 55, 1982. Final report of the International Commission for the study of locks, salt water penetration control devices, Chapter 12, p. 366375 .

13. Ockhuysen, C. P., 1983. A mathematical advection-dispersion model to optimize the freshwater and salt-water intrusion due to the exchange in navigation locks, Proc. XXIAHR Congress, Moscow, vol. 5, 431-439.

14. Hillen, J. G., Ockhuysen, C. P., and Kuur, P., 1984. The technical and economic aspects of the water separation system of the Krammer Locks, Water Science Technology, Rotterdam, vol. 16, 131-140.

15. Van der Kuur, P., 1985. Locks with devices to reduce salt intrusion. J. Waterway, Port, Coastal, Ocean Eng., Proceedings of the American Society of Civil Engineers, vol. 111, No. 6, 1009-1021.

16. Kolkman, P. A., 1986. Methods employed to limit saltwater-freshwater exchange in locsk. Delft Hydraulics Comm. No. 364. Delft, the Netherlands.

17. Tran, D. N. and Merveille, J. L., 1986. Problemes de penetration des eaux ales dans les voies d'eau inteerieures, PIANC Bulletin No. 53, 79-95.

18. Ding Xingrui and Zhou HuaXing, 1988. Design and test of the salt-prevention system at Haihe Lock, Technical Report No. 3, Tianjin Research Institute of Water Transport Engineering, Tianjin, China.

19. Zhou HuaXing, Wang Bingzhe, Zhang Furan, and Sun Yuping, 1989. A study on the lock with the exchange system to reduce saltwater intrusion, Technical Report No. 13, Tianjin Research Institute of Water Transport Engineering, Tianjin, China.

20. Permanent International Association of Navigation Congresses (PIANC), 1993. Problems created by saltwater infiltration, Report of Working Group No. 6, Supplement to Bulletin No. 80, Brussels.

21. Kerstma, J., Kolkman, P. A., Regeling, H. J., and Venis, W. A., 1994. Water quality control at ship locks- prevention of salt- and fresh-water exchange, A. A. Balkeme, Rotterdam. 
22. Mausshardt, Sherrill and Singleton, Glen, 1995. Mitigation salt-water intrusion through Hiram M. Chittenden, Locks, Journal of Waterway, Port, Coastal and Ocean Engineering, American Society of Civil Engineers, July/August 1995.

23. Kiamo, Cesar, 1999. Ways of reducing salt water intrusion through locks. Unpublished report, Panama Canal Commission, Panama. 


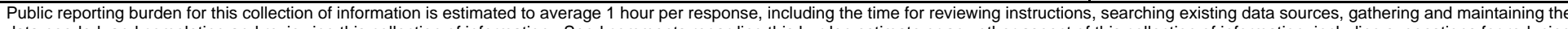

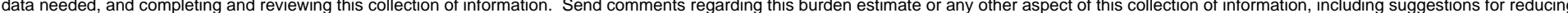

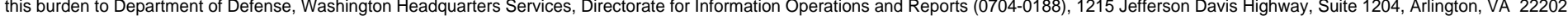

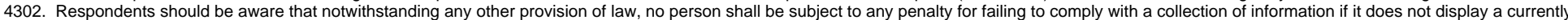
valid OMB control number. PLEASE DO NOT RETURN YOUR FORM TO THE ABOVE ADDRESS.

\begin{tabular}{l|l|l} 
1. REPORT DATE (DD-MM-YYYY) & 2. REPORT TYPE & 3. DATES COVERED (FrOm - TO)
\end{tabular}

April 2000 Final Report

4. TITLE AND SUBTITLE

Salinity Intrusion in the Panama Canal

5a. CONTRACT NUMBER

5b. GRANT NUMBER

5c. PROGRAM ELEMENT NUMBER

6. AUTHOR(S)

T. M. Parchure, Steven C. Wilhelms, Soraya Sarruff, William H. McAnally

5d. PROJECT NUMBER

5e. TASK NUMBER

5f. WORK UNIT NUMBER

8. PERFORMING ORGANIZATION REPORT NUMBER

ERDC/CHL TR-00-4

U.S. Army Engineer Research and Development Center

Coastal and Hydraulics Laboratory

3909 Halls Ferry Road

Vicksburg, MS 39180-6199

\section{SPONSORING / MONITORING AGENCY NAME(S) AND ADDRESS(ES)}

Canal Capacity Projects Office

U.S. Army Engineer District, Mobile

Panama Canal Commission

Mobile, AL 36602

Panama

12. DISTRIBUTION / AVAILABILITY STATEMENT

Approved for public release; distribution is unlimited.

\section{SUPPLEMENTARY NOTES}

\section{ABSTRACT}

The Panama Canal connects the Atlantic and Pacific Oceans for purposes of navigation. On its way it crosses Miraflores Lake and Gatun Lake. Three navigation locks at each end of the Canal lift ships from the ocean to Gatun Lake through a height of $26 \mathrm{~m}$ (85 feet) above sea level and then lower them through three locks, bringing them back to the ocean level. Fresh water from Gatun Lake used for filling the locks is eventually lost to the sea while transferring ships from the lake to the sea. The net loss of fresh water is about 52 million gallons per lockage operation. Salt water from the ocean gets added to the lake during transit of ships from the ocean to the lake. Currently about 38 ships transit the Canal daily. The Panama Canal Commission (PCC) is considering engineering options for increasing the number of vessels transiting each day. It is feared that increased saltwater intrusion may occur and the Gatun Lake water may also become unsuitable for drinking. The Coastal and Hydraulics Laboratory of the U.S. Army Engineer Research and Development Center (ERDC), Waterways Experiment Station, (WES), Vicksburg made preliminary computations for the extent of salt intrusion and a feasibility-level evaluation of mitigation measures.

The work consisted of the following: a. Examination of field data, b. Review of literature on prevention of salt water intrusion in navigation locks, c. Mass balance model for Miraflores and Gatun lakes. d. Evaluation of salinity intrusion and freshwater consumption mitigation alternatives. The following numerical tools were developed: a. A simple mixing analysis coded in spreadsheet form that provides zerodimensional models for the salinity of individual locks and the two lakes plus a freshwater consumption model for Gatun Lake.

(Continued)

15. SUBJECT TERMS

16. SECURITY CLASSIFICATION OF:

\begin{tabular}{l|l|l}
\hline a. REPORT & b. ABSTRACT & c. THIS PAGE \\
UNCLASSIFIED & UNCLASSIFIED & \\
\hline
\end{tabular}

17. LIMITATION OF ABSTRACT 18. NUMBER
OF PAGES

148 19a. NAME OF RESPONSIBLE PERSON

19b. TELEPHONE NUMBER (include area code) 
13. (Concluded).

b. A depth-integrated two-dimensional numerical model for dispersive transport of salt water into Gatun Lake. c. A width-integrated two-dimensional numerical model for densimetric advection and dispersion of salty water from the locks into a channel. The zero-dimensional models have been adjusted to yield results roughly comparable to a limited field observation of salinity in the Panama Canal. The twodimensional models are physics-based and have been successfully applied in many applications; however, they have not yet been verified to field observations in Gatun Lake.

A feasibility-based evaluation of the following alternatives was conducted: a. Use of holding ponds to conserve fresh water by recirculating lift water. b. Installation of a Syncrolift lock chamber adjacent to the Miraflores and Gatun Locks. c. A sump in the channel upstream of the locks to capture more dense salty water and drain it from the lake. $d$. A gated chamber upstream of the locks to hold salty water while it is drained to the sea and replaced with freshwater.

An analysis of results showed that: a. Freshwater consumption can be reduced by up to about 60 percent by recirculating lift water through holding ponds, albeit at the cost of increasing salinity in the ocean approach channels and ultimately in the uppermost locks. If this option is employed, the potential for increased salinity intrusion and necessary remedial measures should be addressed. b. A sump in the channel upstream of the locks can capture salt water for withdrawal. It is most effective for higher salinity water in the locks; however, higher salinity in the locks risks greater salinity contamination of the lake if any lock water escapes the sump. A sump will require some sort of confined channel upstream of the lock to train the densimetric flow out of the lock. c. A salinity higher than $0.3 \mathrm{ppt}$ in the uppermost locks, including a Syncrolift lock, risks unsatisfactory buildup of salt water in Lake Gatun unless some means of capturing most of the salt water is incorporated in the facility. $\mathrm{d}$. A gated chamber on the lake side of the uppermost lock offers the option of draining salty water from the lock and replacing it with fresh water before opening for ship passage. This technique provides positive salinity control at the standard or Syncrolift locks at the cost of a delay in the vessels' exit of the lock.

The following recommendations are made: a. Further consideration may be given to recirculating lift water through holding ponds as a means of freshwater conservation. b. Further consideration may be given to a gated chamber at the uppermost lock entrance on each side to reduce salinity intrusion into Gatun Lake if either the Syncrolift lock or the holding pond/recirculation alternatives are considered for design. c. Tools developed may be used in the design phase of any canal improvement plans. They should be verified to a comprehensive field data set of water levels, velocities, salinities, and temperatures before use in a design effort. d. A numerical model of the sea approaches may be developed to calculate the salinity there under any alternative that might alter the salinity. e. Field data collected in support of further modeling should be synoptic to the maximum degree possible, should include acoustic Doppler current profiling, and should include salinity meters capable of measurements to hundredths of parts per thousand concentration. 
Destroy this report when no longer needed. Do not return it to the originator. 